\title{
LIVRE-DOCÊNCIA
}

\section{ALTERAÇÃO HIDROTERMAL E METALOGÊNESE EM SISTEMAS VULCANO-PLUTÔNICOS PALEOPROTEROZÓICOS NA PROVÍNCIA AURÍFERA DO TAPAJÓS, CRÁTON SUL AMAZÔNICO, PARÁ}

Caetano Juliani

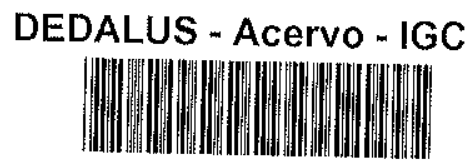

30900011468

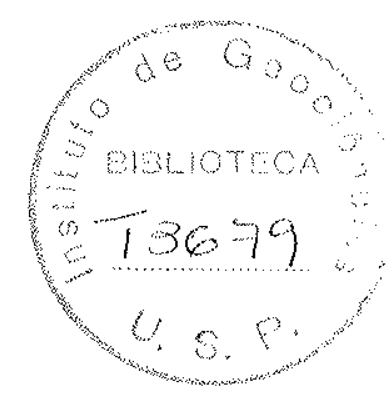

Tese apresentada para o Concurso de Livre-Docência junto ao Departamento de Mineralogia e Geotectônica do Instituto de Geociências da Universidade de São Paulo, na Área de Especialidade Petrologia Metamórfica.

São Paulo 
João, Fábio Taioli, Giannini, Sylvio, Benjamin. Mário, Miguel e Oswaldo. Aos colegas, Rômulo, Wilson, Umberto, Ulbrich e Celso, por muitos dos encaminhamentos e auxílios prestados.

Ao pessoal da Seç̧ão de Transporte, Miltonete, Durval, Antônio, Joselito e Mauro, pela dedicação, amizade e profissionalismo.

Aos amigos e colegas de alto nível profissional que, de uma forma ou de outra, sempre nos socorrem e inspiram, em especial ao Paulo Beljarskis, Reiner Neuman, Arnaldo Alcover, Nilson Teixeira, Gelson Fambrini, Fernando Fernandes, Fernando Moya, Alexandre Chiarini, Cássio Guimarães, Nelson Batistuchi, Andrea Mattos, Abílio Nunes, Anderson Moraes, Prof. Tharcísio de Souza Santos, Prof. Setembrino Petri, Prof. Gilberto Amaral (in memorian), Elton Dantas, Elton Santos, Fábio Mozer, Claudiomara, Marco Aurélio de Oliveira, Peter Hackspacher, Washington Leite Jr., Bruno Payola, Claudio Lamarão, Roberto Dall'Agnol, Pedro Jacobi, César Torresini, Marcos Alves de Almeida, Magda Bergmann, Gustavo de Abreu e Leonardo Van Halsema.

Agradeço especialmente à FAPESP, na pessoa do Prof. José Fernando Perez, e a todo pessoal administrativo, especialmente pelo projeto Proc. 98/02567-6, que possibilitou estas pesquisas.

Ao CNPq, pelas bolsas de R.H. Corrêa Silva, C.M.D. Nunes e F.C. Freitas e ao projeto PRONEX UFPA (662103/1998).

À Rio Tinto Desenvolvimentos Minerais Ltda., pela ajuda nos trabalhos de campo, pela cessão de amostras, dados geológicos e materiais, muito obrigado.

Dedico também este trabalho àqueles que não se conformam com o subdesenvolvimento intelectual, o mercantilismo na educação, o privilégio da estética ao invés da ética e do conteúdo, a destruição das universidades, levada a cabo por dirigentes nacionais, estaduais e institucionais, e a "educação" por progressão compulsoriamente contínua.

À SBG, pela sua competência e ética.

Agradeço ainda à empresas GeoLogos e BTX pela ajuda e inúmeros apoios prestados.

Por fim, ainda dedico esta tese aos alunos da Geologia da USP, ainda mais especialmente àqueles que não acreditam no pacto da mediocridade, nos cursos "bola na rede" e "casas bahia", dentre profusos análogos. 


\section{SUMÁRIO}

\section{CAPÍTULO I}

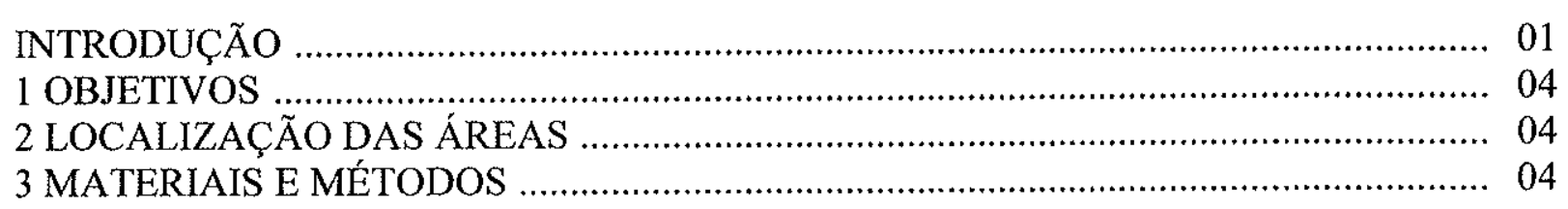

\section{CAPÍTULO II}

\section{SÍNTESE DA GEOLOGIA DA PROVÍNCIA AURÍFERA DO TAPAJÓS}

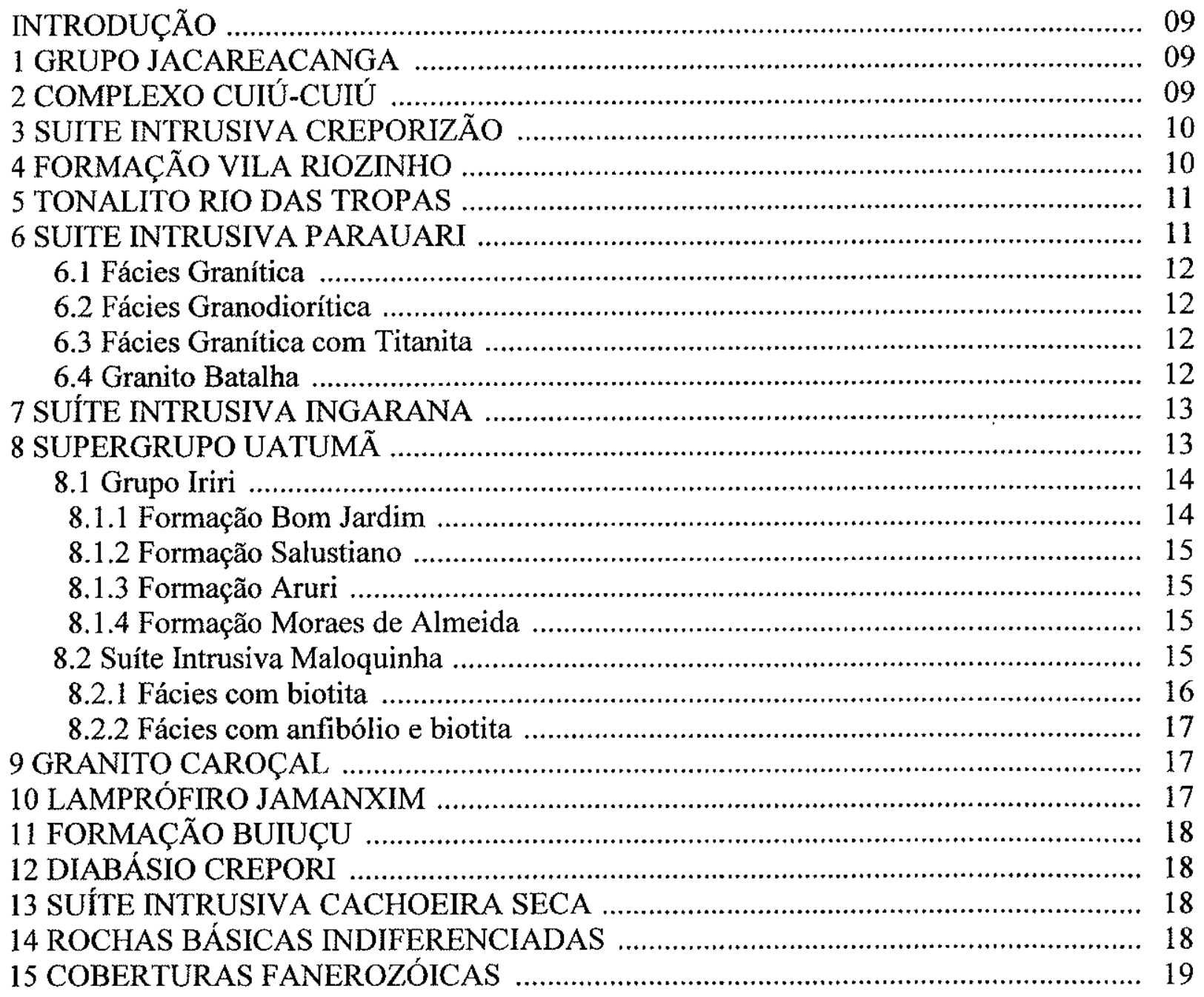

\section{CAPÍTULO III}

(Anexo I)

PALEOPROTEROZOIC HIGH-SULFIDATION MINERALIZATION IN THE TAPAJÓS GOLD PROVINCE, AMAZONIAN CRATON, BRAZIL: GEOLOGY, MINERALOGY, ALUNITE ARGON AGE AND STABLE ISOTOPE CONSTRAINTS

Abstract 20

1. Introduction 


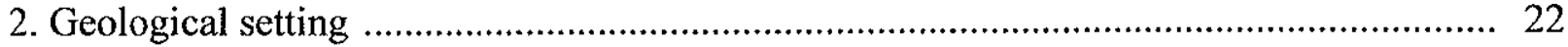

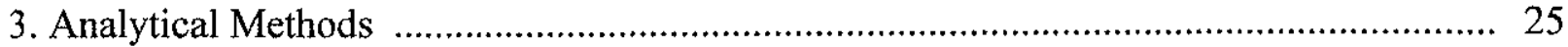

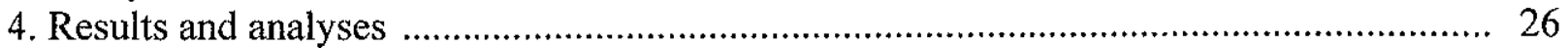

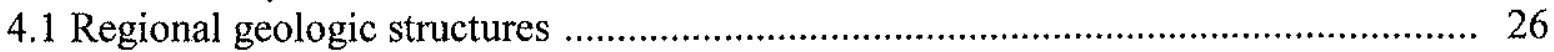

4.2. Geologic setting of the high-sulfidation mineralization ................................... 26

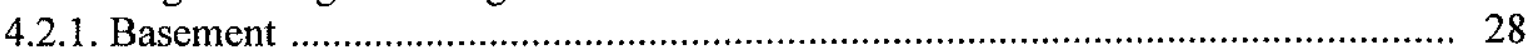

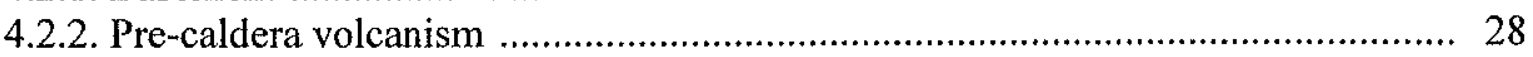

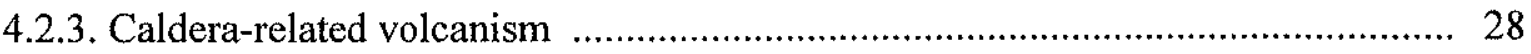

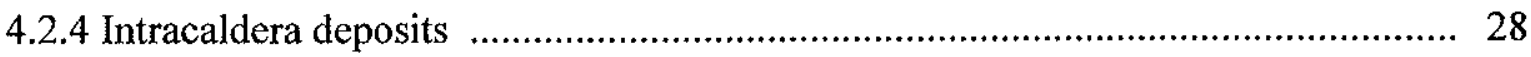

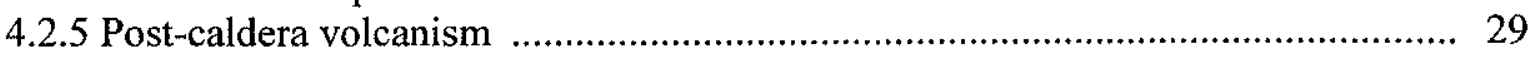

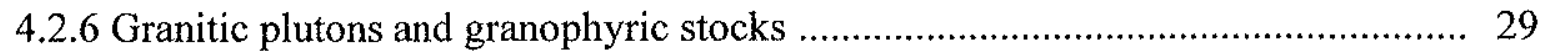

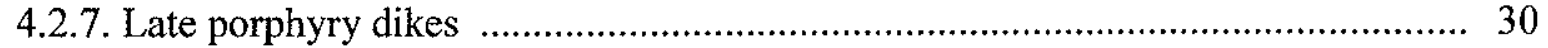

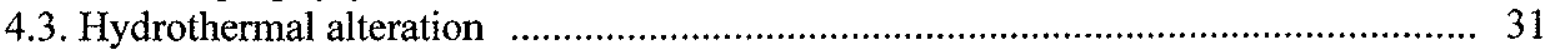

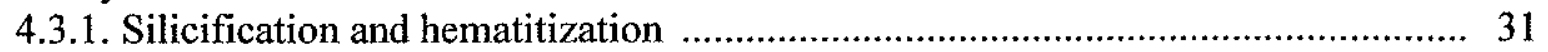

4.3.2. Advanced argillic alteration with quartz and alunite .................................... 33

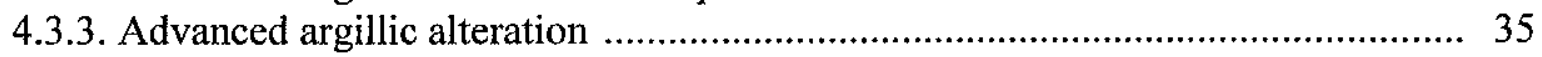

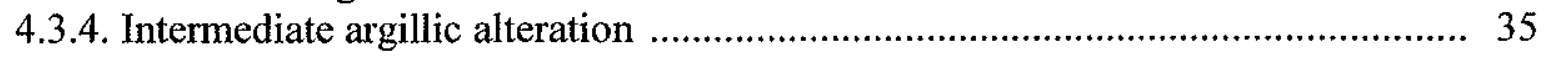

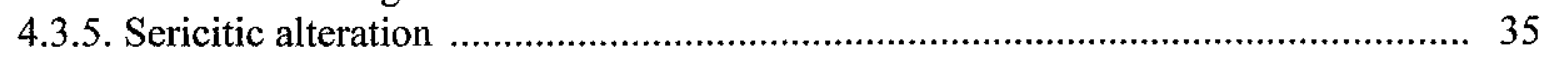

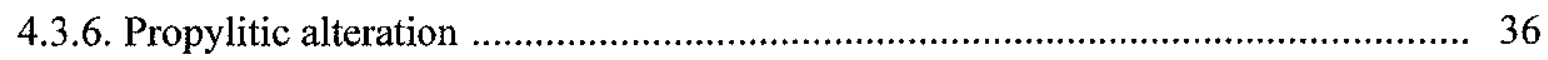

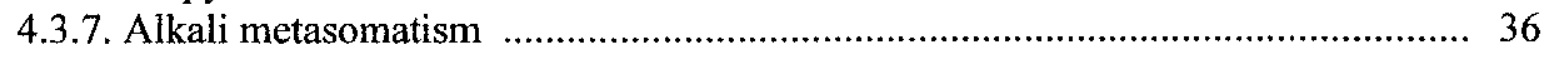

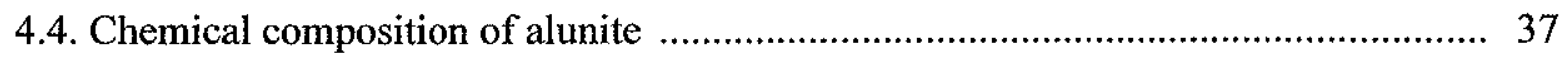

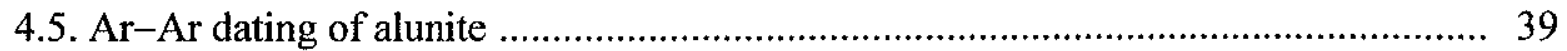

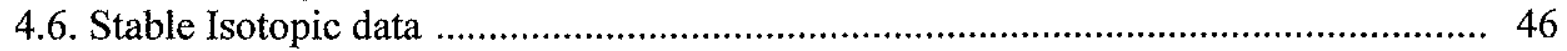

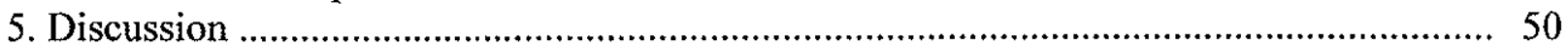

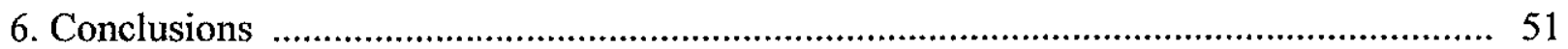

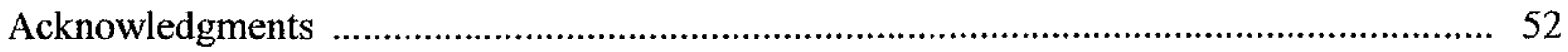

\section{CAPÍTULO IV}

(Anexo II)

THE BATALHA AU-GRANITE SYSTEM - TAPAJÓS GOLD PROVINCE, AMAZONIAN CRATON, BRAZIL: HYDROTHERMAL ALTERATION AND REGIONAL IMPLICATIONS

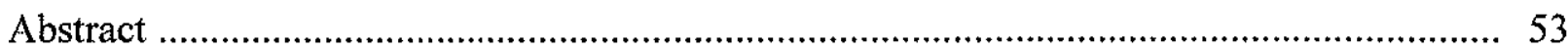

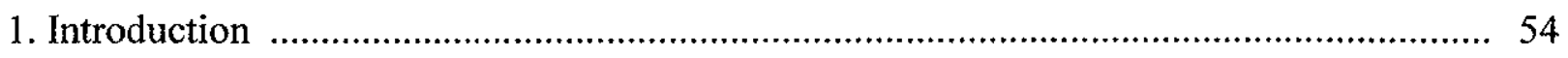

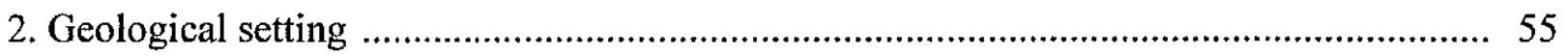

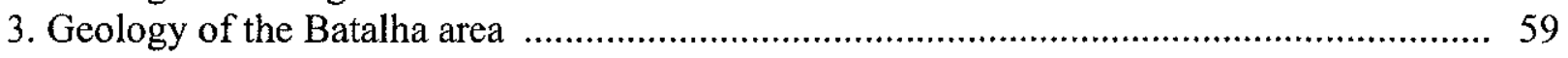

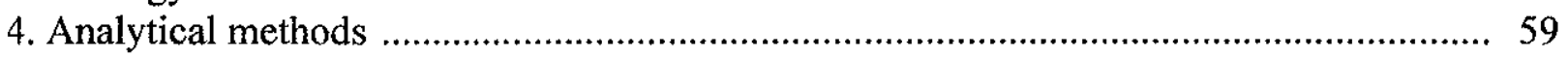

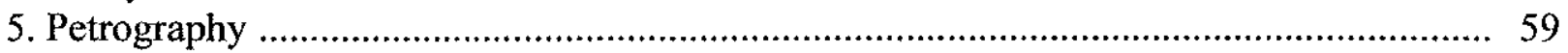

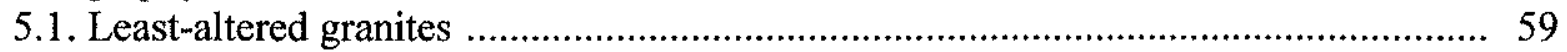

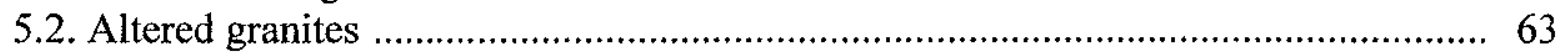

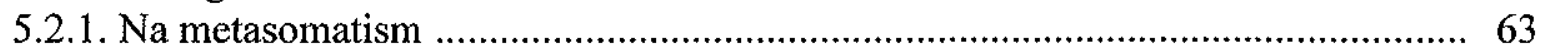

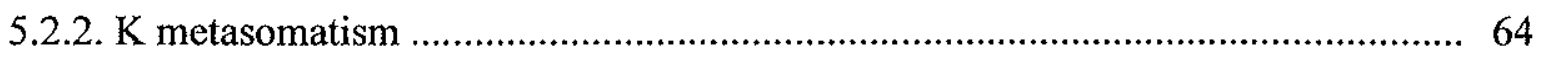

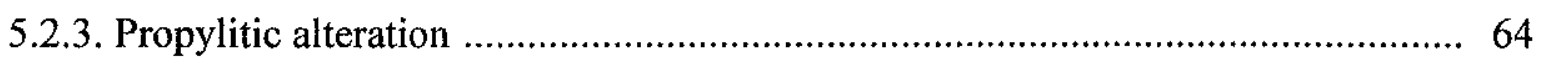

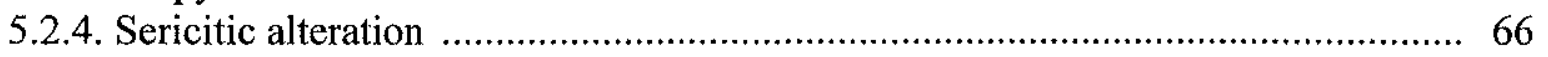

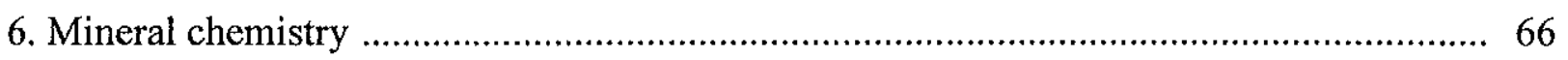

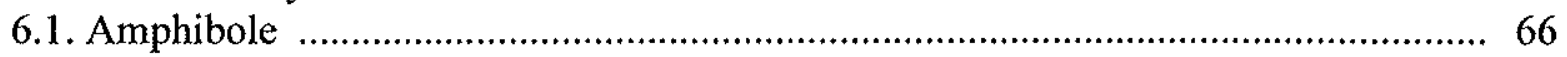

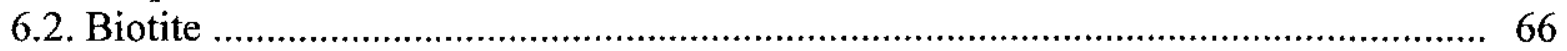

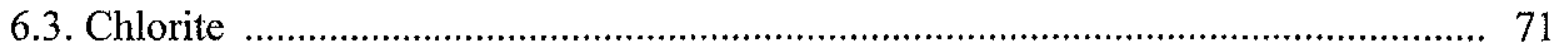

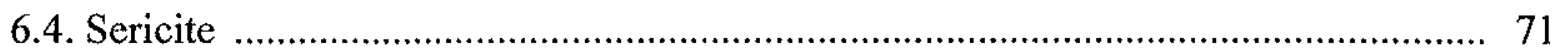

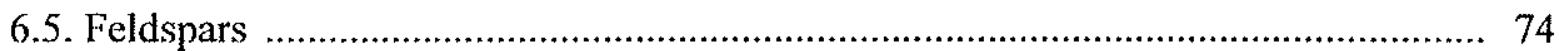


7. Thermobarometry for magmatic and hydrothermal assemblages .............................. 76

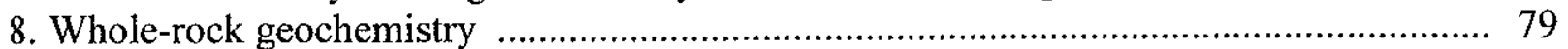

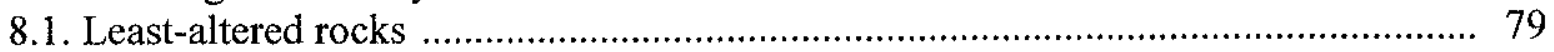

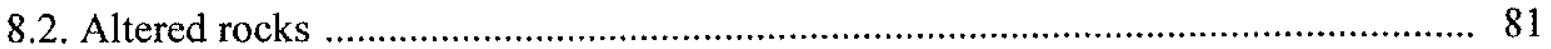

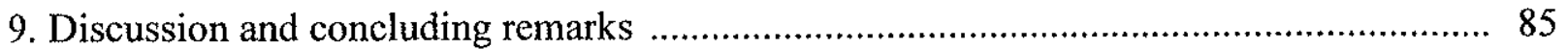

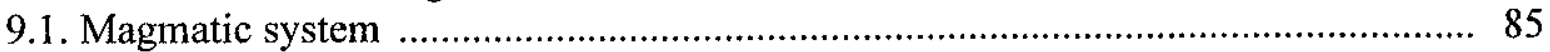

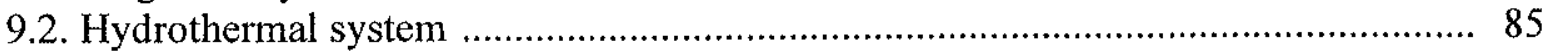

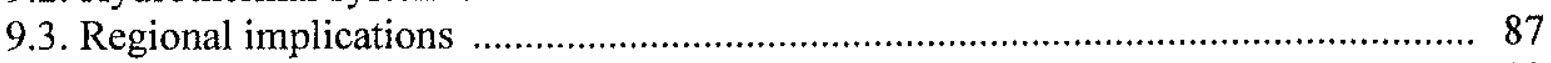

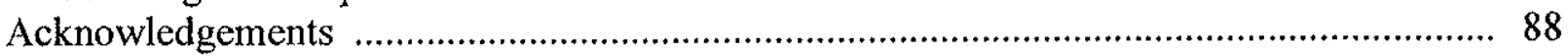

\section{CAPÍtulo V}

(Anexo III)

\section{EVALUATION OF ALUNITE ARGON AGES AND FLUID INCLUSION INTEGRETY: STEP-WISE NOBLE GAS HEATING EXPERIMENTS ON 1.87 Ga ALUNITE FROM TAPAJÓS GOLD PROVINCE, BRAZIL}

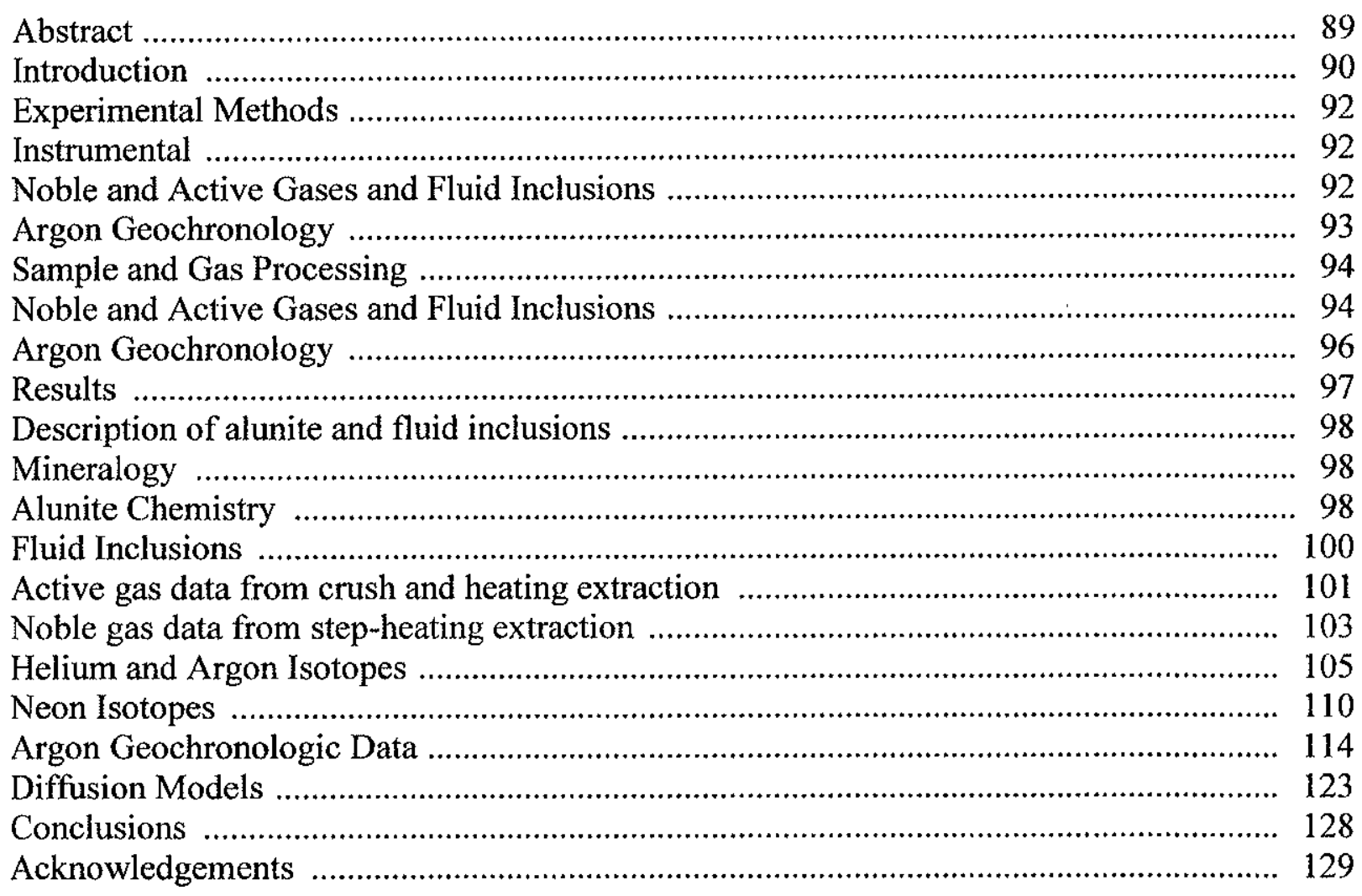

\section{CAPÍTULO VI}

\section{MINERALIZAÇÕES LOW-SULFIDATION}

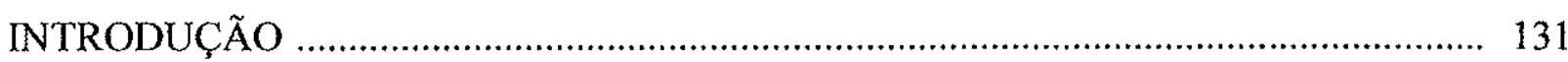

1 GEOLOGIA E LITOLOGIA ………........................................................... 131

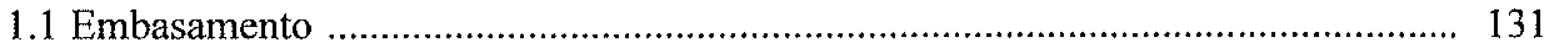

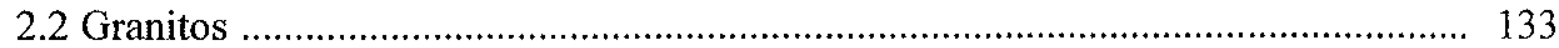

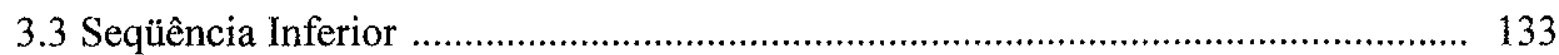

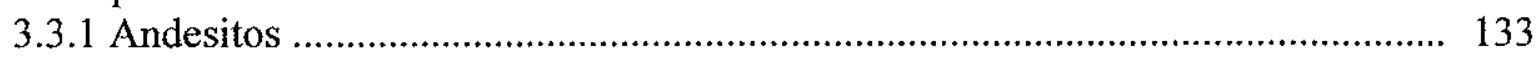

3.3.2 Riolitos porfiríticos ................................................................................... 134 


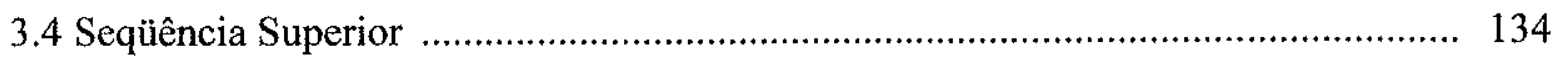

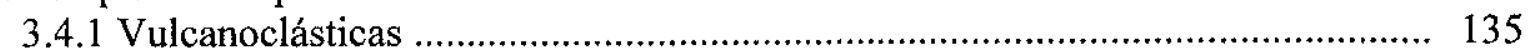

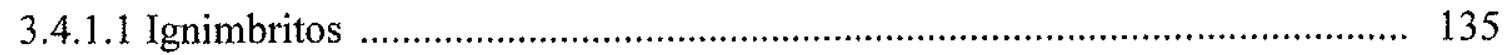

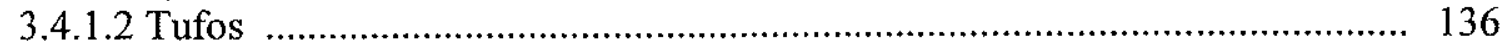

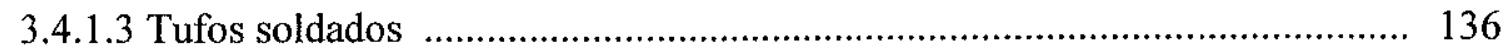

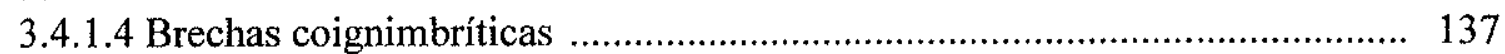

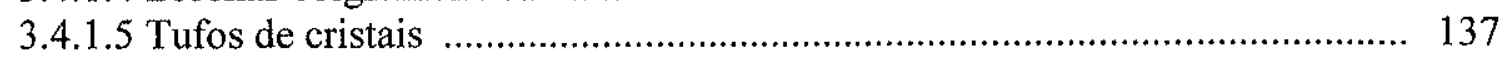

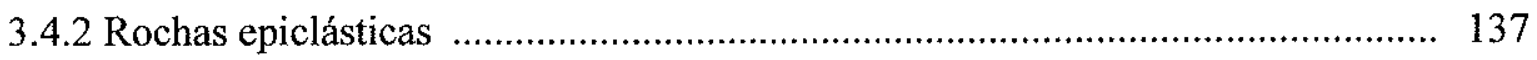

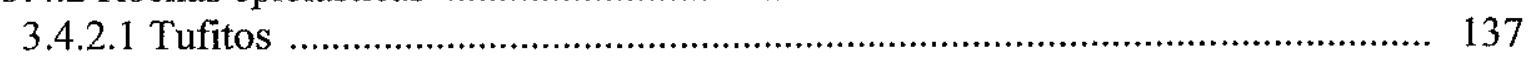

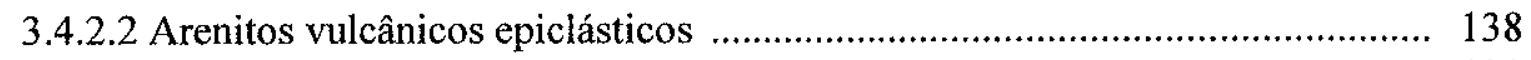

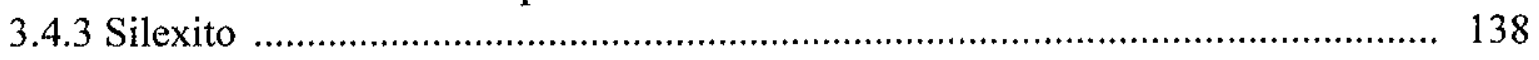

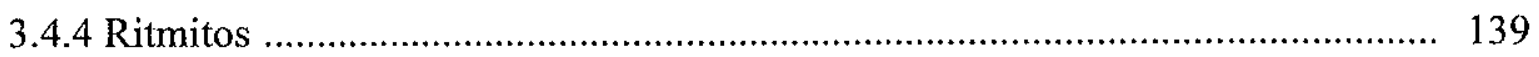

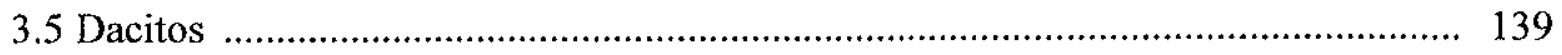

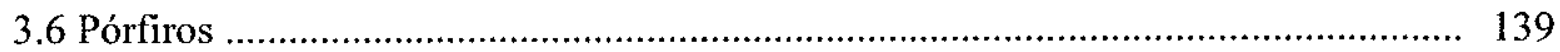

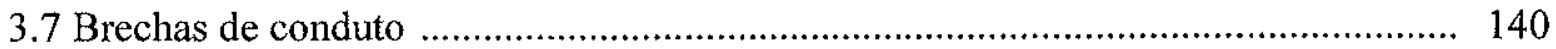

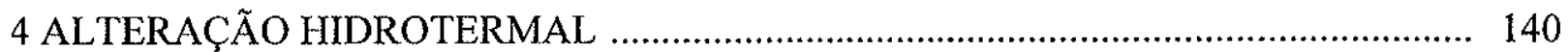

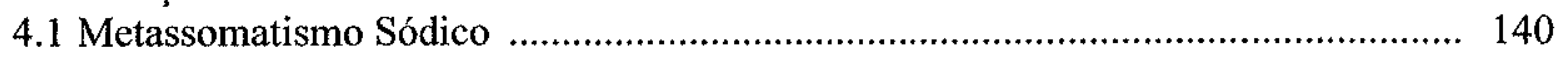

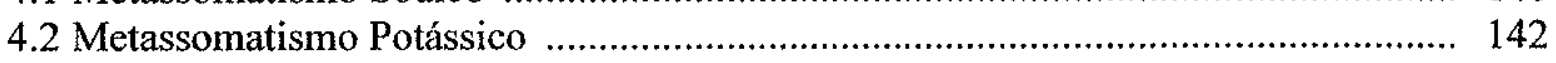

4.3 Alteração Sericítica com Adulária .............................................................. 143

4.4 Alteração Propilítica com Adulária …........................................................ 145

4.5 Alteração Argílica .................................................................................... 149

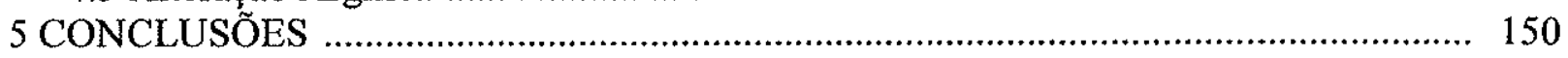

\section{CAPÍTULO VII \\ CONSIDERAÇÕES FINAIS}

1 METALOGÊNESE DO OURO E DE METAIS DE BASE ....................................... 153

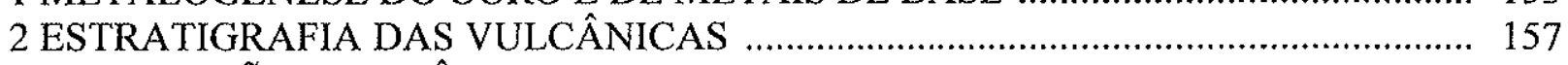

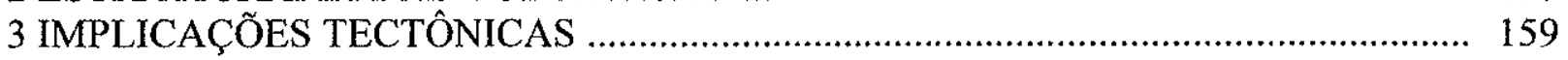

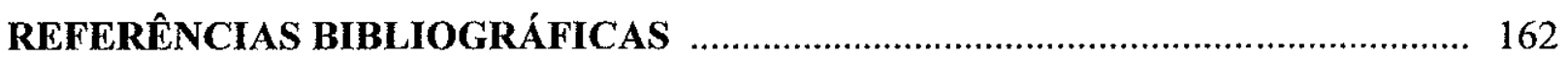

\footnotetext{
Errata:

No Sumário e nos ítens do Capítulo V, onde se lê 2.2 Granitos, leia-se 1.2 Granitos, e assim sequenciadamente, até o final do Capítulo.

Nota-se ainda alguns caracteres estranhos nos Capítulos III, IV e VI, produto da falta de comunicação entre os PCs e os Maclntoshs, apesar das revisões feitas.
} 


\section{CAPÍTULO I}

\section{INTRODUÇÃO}

Esta Tese de Livre-Docência é resultado de pesquisas iniciadas em meados de 1998, apoiadas pela Rio Tinto Desenvolvimentos Minerais - RTDM, para caracterização mineralógica e petrográfica de rochas paleoproterozóicas hidrotermalizadas na Província Aurífera do Tapajós (PA). Estes estudos enfocaram inicialmente duas áreas com rochas mineralizadas e hidrotermalizadas, uma hospedada vulcânicas e vulcanoclásticas do Grupo Iriri, objeto da dissertação de mestrado de Carmen Maria Dantas Nunes, e outra nos granitos do Garimpo Batalha, preliminarmente estudados por Rafael Hernandes Corrêa Silva em seu Trabalho de Formatura. Posteriormente uma terceira zona de alteração hidrotermal, também hospedada em em vulcânicas, vulcanoclásticas e epiclásticas, foi objeto da dissertação de mestrado do último autor. Todos estes estudos foram orientados pelo candidato a este concurso.

As vulcânicas, vulcanoclásticas e sedimentos associados na região estudada na Província Aurífera do Tapajós encontram-se, pelo menos parcialmente, metamorfisadas em grau muito baixo (Very Low Grade Metamorphism - VLGM), com cristalização de clorita e zeólitas nas vulcânicas e sericita + clorita + argilo-minerais nos sedimentos e vulcanoclásticas. As deformações são muito fracas e localizadas, consistindo em leves ondulações, com incipiente orientação de micas segundo os planos axiais das dobras. Entretanto, como as zonas de alteração hidrotermal são muito extensas, pervasivas e intensas, e como os levantamentos em campo limitaram-se a poucos quilômetros ao redor dos centros hidrotermais, parte das paragêneses consideradas como geradas por metamorfismo regional podem ter sido formadas nos halos mais externos e superficiais da alteração, semelhantemente ao verificado em campos geotermais atuais (Hemley, 1985). Neste caso, seria melhor classificar o metamorfismo como hidrotermal (Juliani et al., 2002), mas são ainda necessários estudos regionais para definição desta questão, que será abordada no doutoramento de Fernando Camargo Freitas e de Rafael Hernandes Corrêa Silva, em inicio de desenvolvimento.

Devido ao grau incipiente do metamorfismo, as rochas serão identificadas nos textos apresentados pelos seus protolitos.

Os estudos feitos na primeira área permitiram a caracterização da existência de um sistema epitermal high-sulfidation fóssil com cerca de 1,86 Ga, que constitui-se no mais antigo deste tipo já descrito, e o único até o momento no Brasil.

A denominação high-sulfidation aqui utilizada baseia-se no estado de oxidação do fluido, como proposto por Hedenquist (1987), e corresponde aos sistemas high-sulfur (Bonham, 1984), quartz-alunite (Berger, 1986) ou acid sulfate (Heald et al., 1987). Berger \& Henley (1989) 
À Maria Rosa, Luiz Fernando,

Dona Cleide e, em especial,

ao meu pai 


\section{Agradecimentos}

Um agradecimento muito especial é devido à Lena, exemplo de competência profissional e, sobretudo, grande companheira de todas as horas e peça imprescindivel na elaboração e montagem deste texto.

À Thatyana Benevides, por toda ajuda na confecção desta tese. Sem sua ajuda este volume jamais ficaria pronto. A você, muito obrigado.

Agradeço ainda a todos os meus orientados, profissionais de alto nível, companheiros e amigos, mas sobretudo, amantes da geologia "honesta". Todos foram um estímulo contra as medíocres ações persecutórias, tão comuns em tantos locais. Fernando, Rafael, Carmen, Annabel, Thatyana, Andrés, Klaus, Gustowo, Silvano, Gisele e Jonas, muito obrigado a todos vocês.

Em especial agradeço ao Rafael, cuja capacidade de realização e competência não tem limites, razóes pelas quais, certamente, sofre por críticas daqueles que pouco sabem de geologia e da vida.

À Carmen, pela responsabilidade em me chamar ao estudo da Amazônia. A você, que faz falta aqui, meu muito obrigado.

Ao colega Robert Rye (USGS), por toda ajuda e paciência na elaboração de nossos textos e, sobretudo, pelas inúmeras análises isotópicas.

Ao longo de alguns anos de convívio institucional muitas amizades são criadas, mas sempre há pessoas especiais. Especiais pelo seu carisma, competência e profissonalismo, mas principalmente, pela sua honestidade e ética, procedimentos estes cada vez mais dificeis de serem encontrados, sobretudo pelo exemplo dado todos os dias pelos nossos dirigentes em todos níveis. Eu venho então expressar meus agradecimentos a estas pessoas especiais, que não se conformam com os desmandos e o autoritarismo dos dias de hoje.

Em especial, agradeço à Valéria e à Soninha, pelos seus imprescindiveis e inestimáveis apoios e auxilio em todos os dias.

Às eficientíssimas e alegres Ana Paula e Magali, pelas tantas ajudas e pela amizade.

Ao pessoal dos laboratórios, em especial ao Marcos, Rosa, Flávio, João, Paulinho, Sandra, Marinês, Ricardo, Luiz Paulo, João Paulo, Artur, Reynaldo, Angélica, Ana e jaime.

À turma da biblioteca, Rosa, Maria Aparecida, Maristela, Brenda e Érica, porque sem a sua eterna assistência eu não sobreviveria.

Claudio, Luiz e Paulo, muito obrigado por toda ajuda, competência e eficiência na confecção de nossas lâminas, porque quem sabe usá-las entende que elas são pequenas jóias.

Ao Claudionor, Edemir, Dalton, Henrique e josé, sempre prontos e dispostos, pelo grande profissionalismo na confecção desta tese, das dos meus orientados e de todos os materiais didáticos que sempre insistimos em elaborar, apesar da estranha, mas passageira, brisa.

Ao pessoal da administração, pela ajuda em tantas coisas, todos os dias, que seria impossível listar. Ivone, Maurício, José, Luiz (o secretário-mor das infindáveis sindicâncias), Nilva, Elias, Celeste, Nícia, Cristina, Iolanda, Regina, Verinha, Tadeu, Sônia, Marlene, Rosana e Marilda, um grande abraço a todos vocês.

Sem o apoio didático quase nada poderíamos fazer por nossos alunos. Quirino, José Carlos, Paulo e Wagner, muito obrigado.

Ao pessoal da manutençāo, em especial ao Marcos, Silvio, Genivaldo, Manuel, Clodoaldo, Nelson, Marivaldo e Kid, pela amizade, eficiência e prestatividade de todos os dias. Um abraço ainda à turma da vigilância, limpeza e copa, principalmente à Dona Maria, à Celina e à Lurdes.

Aos colegas verdadeiros, sejam como pessoas, seja como professores e cientistas, pelas infinitas e produtivas discussões (e muitas vezes, divergências!!!), notadamente ao jorge, Rosa, Teodoro, Fábio Ramos, lan, Gergely, Angela, Joel, Uriel, Ivo, Raphael, Hans, Kazuo, Aneli, Lilia, Thomas, Marly, Schultz, Coutinho, Darcy, Paulo, Daniel, Annabel, Eliana, Claudio, Sônia, Gianna, 
preferem a denominação baseada na mineralogia, identificando este tipo de sistema hidrotermal como alunite-kaolinite e Ashley (1992), o denomina enargite-gold.

A necessidade da algumas análises isotópicas específicas para definição da idade e do tipo do fluido do sistema levou ao início do estabelecimento de cooperação científica com o Dr. Robert O. Rye do Uniled States Geological Survey em 1999 e a singularidade desta ocorrência de mineralização high-sulfidation provocou um convite dos organizadores da GSA Topical Session T-37 - Sulfate Minerals: Hydrothermal Systems (A Tribute to Robert O. Rye) e da Geological Society of Economic Geologists para apresentação dos dados preliminares no Geological Society Annual Meeting - Summit, em 2000. Nesta oportunidade foram estabelecidos contatos que permitiram a elaboração de dois artigos submetidos à Chemical Geology, que compõem o corpo principal desta tese de Livre-Docência, apresentados nos Anexos I e III (capitulos III e V). Em decorrência dos estudos sobre a gênese da mineralização high-sulfidation foi caracterizado pela primeira vez no Brasil um sistema de caldeiras paleoproterozóicas ressurgentes, que constituiu-se em um dos mais antigo e bem preservados já descritos.

A continuidade das pesquisas sobre as mineralizações de ouro no Granito Batalha mostrou também algumas peculiaridades, com alterações hidrotermais pervasivas extensas, com zonas de alteração sódica, potássica, propilítica e sericítica, cujas principais caractísticas petrográficas e químicas assemelha-se aos produtos de alterações em sistemas hidrotermais do tipo Pórfiro, mas com algumas semelhanças com alterações relacionadas a mineralizações do tipo Intrusion-related gold systems (Lang \& Baker, 2001). A identificação das alterações potássicas pervasivas intensas e extensas e o quimismo permitiu a distinção do Granito Batalha da Suite Intrusiva Maloquinha, que tem, tipicamente, cor vermelha, sendo então correlacionado aos eventos tardi- a pós-colisionais do magmatismo Parauari, o que, em conjunto com a identificação dos sistemas high-sulfidation, sugere a possibilidade da preservação de suites graníticas rasas, que podem ter sido responsáveis pela formação das caldeiras onde desenvolveram-se os sistemas epitemais nas vulcânicas e subvulcânicas. Estes dados resultaram no artigo apresentado no Capítulo IV (Anexo II), aceito para publicação pela Precambrian Research.

Este conjunto de artigos constitui o corpo principal desta tese, em acordo com os regulamentos da Universidade de São Paulo, mas são apresentados como anexos por não estarem escritos em português, por exigência dos mesmos regulamentos.

A finalização desta primeira etapa de pesquisas no Tapajós permitiu ainda a indentificação de um sistema epitermal low-sulfidation (Hedenquist, 1987), também denominado low-sulphur (Bonham, 1986) ou adularia-sericite (Hayba et al., 1985; Heald et al., 1987), geneticamente vinculado com o desenvolvimento das ash-flow calderas e com os granitos da 
Suite Intrusiva Parauari, cuja síntese é apresentada no Capítulo VI, cujo texto é baseado na dissertação de mestrado de Rafael Hernades Corrêa Silva.

Os sistemas epitermais high- e low-sulfidation são formados em ambientes crustais muito rasos ou superficiais, geralmente em profundidades inferiores a $1 \mathrm{~km}$, o que favorece o intemperismo e uma rápida erosão (Hayba et al., 1985). Isto sempre suscitou duvidas quanto à existência ou não de mineralizações destes tipos em períodos mais antigos da evolução do planeta e, consequentemente, sobre semelhanças ou diferenças físico-químicas dos fluídos hidrotermais antigos, relativamente aos mais recentes. Estas descobertas mostram então que a típica ocorrência de mineralizações epitermais high- e low-sulfidation em terrenos terciários e quaternários (Arribas Jr., 1995) deve-se à somente à não preservação pela erosão associada à exumação dos cinturões orogenéticos, e que os sistemas magmáticos e hidrotermais foram, em essência, análogos aos recentes, pelo menos até o final do Paleoproterozóico no Cráton Sul Amazônico.

A rápida erosão faz com que estas mineralizações sejam escassas no Cretáceo (So et al., 1998; Nelson, 2000, Andrews, 2002) e raras no Paleozóico (Thompson et al., 1986). Uma única ocorrência metamorfisada neoproterozóica é descrita (Dubé et al., 1995; Ayuso et al., no prelo) e rochas granulíticas paleoproterozóicas na Suécia tem sido interpretadas como derivadas de mineralizações high-sulfidation (Hallberg, 1994). Assim, as ocorrências na Província Aurifera do Tapajós consistem, até o momento, nas únicas pré-cambrianas quase que totalmente preservadas já descritas.

Quanto a distribuição no tempo geológico, os depósitos do tipo pórfiros mostram semelhança com os sistemas epitermais, sendo predominantemente terciários a mesozóicos. Entretanto depósitos de pórfiros cupríferos, embora raros, são também reconhecidos no Proterozóico, como por exemplo Haib (Southern Namibia) e Malanjkand (India) (Porter, 2001) e 17 Mille Hill (Western Australia), ou até mesmo arqueanos, como Boddington (Australia) e Clark Lake e Troilus (Canada) (Rowins, 2000).

Os três sistemas citados associam-se, tipicamente, a província vulcânicas predominantemente félsicas, sendo gerados em arcos de ilhas ou em arcos magmáticos continentais, mas também estão presentes em campos vulcânicos continentais.

As ash-flow calderas associadas a limites convergente de placas tectônicas caracteristicamente desenvolvem-se em zonas extensionais, em ambiente back-arc ou de intraarc, e, geralmente relacionam-se a grabens, intersecção de lineamentos e zonas transtrativas de zonas de cisalhamento regionais. Estes tipos possuem de grandes dimensões, comumente alcançando mais de $15 \mathrm{~km}$ de diâmetro e são ressurgentes. 
Assim, a identificação destas mineralizações tem como conseqüência implicações não somente metalogenéticas, como também para a definição da formação e estruturação tectônica dos terrenos paleoproterozóicos do Cráton Sul Amazônico.

\section{OBJETIVOS}

Os principais objetivos desta tese são a caracterização dos padrões de alteração hidrotermal registrados em rochas vulcânicas, vulcanoclásticas, epiclásticas do Grupo Iriri latu sensu e subvulcânicas e plutônicas e subvulcânicas da Suíte Intrusiva Parauari na Província Aurífera do Tapajós.

Adicionalmente objetiva-se a definição preliminar de algumas conseqüências metalogenéticas e tectônicas decorrentes da tipologia das mineralizações estudadas.

\section{LOCALIZAÇÃO DAS ÁREAS}

As três mineralizações estudadas, situam-se entre os rios Tapajós e Jamanxim (Fig. 1), sudoeste do Estado do Pará.

A área com mineralizações high-sulfidation (HS) pode ser alcançada por pequenos aviões, uma vez que há uma pista de pouso de garimpo nas proximidades, ou à pé, através de vários dias de caminhada em picadas na mata, a partir do Rio Tapajós.

As mineralizações low-sulfidation (LS) são alcançadas, a partir da cidade de Itaituba, através da Rodovia Transamazônica até um pequeno porto no rio Tapajós, de onde embarca-se em "voadeiras" subindo o rio, a partir da onde atinge-se a área de estudo, caminhando-se por cerca de dois dias em picadas na mata.

O Granito Batalha (GB) é mais facilmente acessível, por situar-se nas proximidades da margem esquerda do Rio Tapajos, junto Rodovia Transamazônica, e por possuir uma pequena pista de pouso, podendo assim ser alcançado por barcos, carros ou aviões.

As três mineralizações inserem-se na denominada Província Aurífera do Tapajós, mas a área LS situa-se fora da área mapeada pelo Projeto PROMIN Tapajós (Fig. 2). A delimitação da área da Província segue aproximadamente a definição original, mas, as características e as distribuições de ouro na região sugerem que a delimitação original pode incluir mais de uma província metalogenética.

\section{MATERIAIS E MÉTODOS}

Nos levantamentos em campo foram utilizados principalmente os mapas topográficos e geológicos e elaborados pela RTDM, uma vez que as bases topográfica regional mais detalhada estão na escala de 1:250.000. 


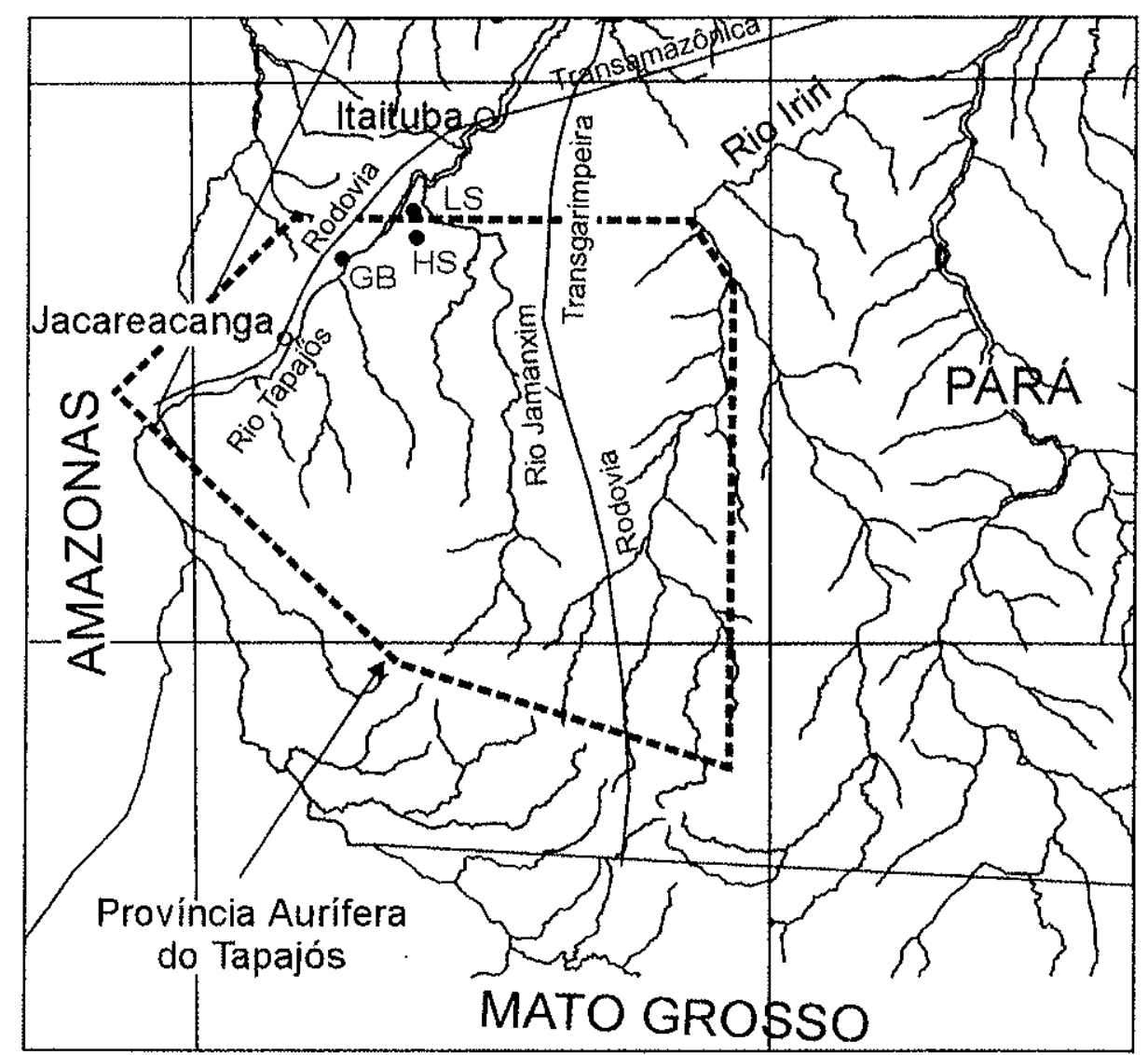

FIGURA 1 - Localização das mineralizações estudadas. HS = high-sulfidation, LS $=$ lowsulfidation $\mathrm{E} \mathrm{GB}=$ Granito Batalha.

Também foram utilizadas fotocópias de aerofotos na escala 1:70.000 do Projeto FAB-PDC/CPRM, de 1973, imagens TM-LANDSAT e de Radar e aerolevantamentos radiométricos e magnetométricos feitos pela RTDM, estes especialmente utilizados para definição da estruturas tectônicas, vulcanogênicas e plutogênicas regionais. As imagens de Radar utilizadas foram as do Projeto RADAM/BRASIL e as do NASDA/JERS-1 SAR, obtidas durante o programa "Global Rain Forest Mapping Project".

$\mathrm{O}$ mapeamento da área foi realizado através de picadas abertas pela empresa para levantamentos geofísicos, trilhas de garimpeiros e picadas especialmente abertas para alcançar-se locais selecionados em função dos levantamentos em andamento, ou para verificação de estruturas morfológicas identificadas através de imagens de satélite e de radar.

Além das amostras de campo, foram amostrados todos os testemunhos de sondagens rotativas feitas nas pela RTDM nas três áreas.

Foram feitos estudos petrográficos em algumas centenas de de secções delgadas e em pouco mais de 30 secções polidas, utilizando-se um microscópio Zeiss, Axioplan Pol, com ocular de $10 \mathrm{X}$ e objetivas de $2,5 \mathrm{X}, 5 \mathrm{X}, 10 \mathrm{X}, 20 \mathrm{X}$ e $40 \mathrm{X}$ do Laboratório de Óptica do GMG-IGUSP. As fotomicrografias foram obtidas com um equipamento Zeiss acoplado ao microscópio. Também foi utilizado um microscópio Olympus, modelo BX-50, com 
equipamento de aquisição de imagens digital Olympus OLY-750 acoplado, com software ImagePro

Nestes estudos foram utilizados os seguinte livros e manuais: Kerr (1959), Tröger (1979), Bard (1986), Ixer (1990), Deer et al. (1993), Mackenzie et al. (1991), MacKenzie \& Adams (1994), Hibbard (1995), Passchier \& Trouw (1996) e Melgarejo (1997).

A análise modal dos granitos foi efetuada em placas de rocha, quando de granulação grossa e porfiríticas e, em secções delgadas, para rochas mais finas. Para contagem modal de rochas faneriticas e porfiriticas, os feldspatos potássicos foram coloridos seletivamente segundo o método descrito por Hutchinson (1974). Em fatias de rochas adotou-se: (1) ataque por 3 minutos com HF a 52\% em capela ventilada, (2) imersão em água destilada, enxague rápido por duas vezes em solução a $5 \%$ de cloreto de bário, e (3) enxague rápido em água destilada, imersão por 1 minuto em solução saturada de cobaltonitrito de sódio e secagem em temperatura ambiente. Em secções delgadas descobertas foi feito: (1) imersão em solução de HF em temperatura ambiente por 10 segundos, (2) imersão em solução de cobaltonitrito de sódio por 15 segundos e rápido enxaguamento para remover o excesso de reagente, (3) imersão rapida em solução de cloreto de bário a 5\% e, (4) enxague rápido em água de torneira e, posteriormente, em água destilada e secagem em temperatura ambiente. Posteriormente as amostras foram cobertas com Bálsamo do Canadá e lamínula convencional.

Diversos minerais, devido à granulação muito fina, foram identificados através de difratometria de raios X. As amostras foram separadas com auxílio de discos serras e brocas diamantadas conectadas a motor de $3000 \mathrm{rpm}$, com haste flexível e posteriormente pulverizadas em almofariz de ágata e preparadas no porta amostra. As interpretações foram efetuadas pelo software Diffracat Plus, utilizando o banco de dados Powder Difraction File, set1-45, de 1995. O difratômetro utilizado foi o modelo SIEMENS D5000 do Laboratório de Difração de R-X do GMG-IGUSP. As análises foram realizadas utilizando-se ânodo de CuKa à tensão de $40 \mathrm{kV}$ e corrente de $40 \mu \mathrm{A}$. Os intervalos de $2 \Theta$ medidos, variaram de $3-652 \Theta$, com passo de 0,5 $2 \Theta /$ s/passo.

A microscopia eletrônica de varredura foi feita no Setor de Caracterização Mineral do CETEM-RJ, em microscópio eletrônico LEO S440, equipado com sistema de microanálise por dispersão de energia Link ISIS L300 com detector de SiLi Pentafet, janela ultrafina ATW II, de resolução de $133 \mathrm{eV}$ para $5,9 \mathrm{keV}$, com microanálises por EDS com feixe de aproximadamente de $1 \mu \mathrm{m}$ de raio e tensão de aceleração de elétrons de $20 \mathrm{kV}$. As amostras foram recobertas com carbono condutor para possibilitar as análises de ouro e, para análises semi-quantitativas por EDS, o padrão de calibração utilizado foi o cobalto. As imagens foram geradas principalmente por detetor de elétrons retro-espalhados (Backscatter Electrons Detector - BSD). 
Química mineral foi feita em microsonda eletrônica JEOL JXA 8600 Superprobe do GMG-IGUSP, com cinco espectrômetros com cristais TAP/STE, TAP/PET, LIF/PET, PET/LIF, automatizada com o sistema Voyager 3.61 da Noran Instruments.. As secções delgadas polidas foram metalizadas com película de carbono de aproximadamente $25 \mathrm{~nm}$ em evaporador Auto 206 da Edwards no Laboratório de Preparação de amostras do GMG-IGUSP.

As análises de plagioclásio, adulária, microclínio e ortoclásio foram feitas com feixe de elétron com o diâmetro de $10 \mu$, corrente de $\sim 20,10 \mathrm{nA}$ e voltagem de $15 \mathrm{kV}$. Para análises de micas, clorita e carbonatos utilizou-se $5 \mu$ como diâmetro do feixe. Os erros totais máximos das análises variam entre 1 e $2 \%$ para elementos maiores, $5 \%$ para elementos menores e acima de $10 \%$ para elementos traço $(<1 \%$ em peso do elemento). A identificação complementar qualitativa de parte dos minerais opacos foi realizada neste mesmo equipamento, por EDS.

Houve ainda a necessidade do desenvolvimento de uma rotina específica de análise para a alunita, devido a alta volatilização do enxofre, empregando-se corrente de $5 \mathrm{nA}$, voltagem de $15 \mathrm{Kv}$ e diâmetro do feixe de $1 \mu \mathrm{m}$.

Os demais métodos utilizados são descritos nos artigos apresentados. 


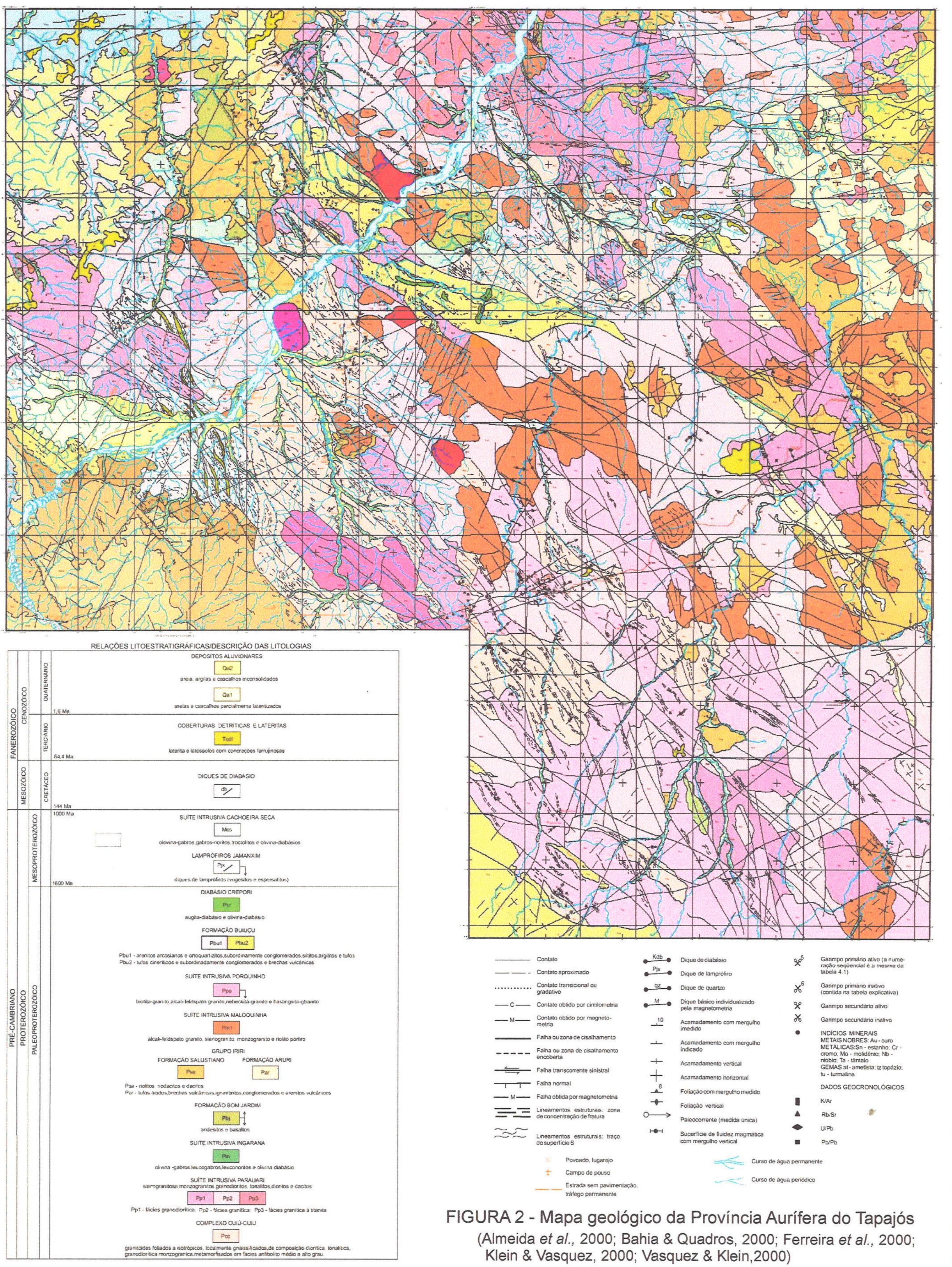




\section{CAPÍTULO II \\ SÍNTESE DA GEOLOGIA DA PROVÍNCIA AURÍFERA DO TAPAJÓS}

\section{INTRODUÇÃO}

A Província Mineral do Tapajós (Santos \& Loguécio, 1984) insere-se na borda sudoeste do Cráton Amazônico, uma unidade tectônica de idade pré-brasiliana dividida em dois importantes escudos situados, respectivamente, a norte e a sul do rio Amazonas, o das Guianas e o do Guaporé, este também denominado de Escudo Brasil Central (Almeida et al., 1976). O Escudo do Guaporé é dividido em duas províncias estruturais, a Tapajós e a Tocantins (Almeida et al., 1977).

Uma das primeiras sínteses da geologia da Província Aurífera do Tapajós, baseada nas informações obtidas nos projetos Jamanxim (Pessoa et al., 1977), Tapajós-Sucunduri (Bizzinela et al., 1980), RADAM - Folha Tapajós (Santos et al., 1975) e demais trabalhos executados pelo DNPM, PROSPEC e CPRM, deve-se a Silva (1982).

O grande acúmulo de dados geocronológicos melhorado muito o conhecimento da estratigrafia da região Amazônica, podendo ser destacados os trabalhos de Santos et al. (1997), Dall'Agnoll et al. (1999), Lamarão et al. (1999), Reis et al. (1999), Santos et al. $(2000 ; 2001)$

As principais unidades geológicas da Província Aurífera do Tapajós podem ser vistas na Fig. 2 (Capítulo I), compilada de Almeida et al. (2000), Bahia \& Quadros (2000), Ferreira et al. (2000), Klein \& Vasquez (2000) e Vasquez \& Klein (2000).

A descrição suscinta das principais unidades é a seguinte:

\section{GRUPO JACAREACANGA}

O Grupo Jacareacanga é constituído predominantemente por micaxistos, quartzo micaxistos, actinolita xisto, talco xisto, quartzito, metachert, metargilito, metagrauvaca, formações ferríferas bandadas e filitos de baixo grau metamórfico (Santos et al., 1997; Ferreira et al., 2000). Sua idade situa-se ao redor de $2,1 \mathrm{Ga}$, como indicado pela datação U-Pb em zircões detríticos em xistos (2.098 a $2.875 \mathrm{Ma})$ e pelas intrusivas graníticas do Complexo CuiúCuiú, que tem idade ao redor de $2.005 \mathrm{Ma}$ (Santos et al., 1997).

\section{COMPLEXO CUIÚ-CUIÚ}

O Complexo Cuiú-Cuiú (Pessoa et al., 1977; Almeida et al., 1998) é composto por migmatitos, gnaisses, anfibolitos e granitóides metassomáticos. Inclui ainda granitóides pré- e sin-tectônicos formados em ambiente de arco-vulcânico e geneticamente relacionados à formação do embasamento gnáissico. É cortado por um sistema de transcorrência com direção 
NW-SE, desenvolvido em regime predominantemente dúctil. Alguns dos granitóides são intrusivos ou encontram-se associados às rochas do Grupo Jacareacanga e apresentam grau metamórfico que pode chegar à fácies anfibolito (Almeida et al., 1999b). Santos et al. (2000) consideram estas rochas como representantes do arco magmático mais antigo da Província Tapajós-Parima, desenvolvido ao redor de $2.005 \pm 7 \mathrm{Ma}$ U-Pb SHIRIMP em zircão.

\section{SUITE INTRUSIVA CREPORIZÃO}

Esta unidade é composta predominantemente por sieno- e monzogranitos, com granodiorito, tonalito e quartzo monzodiorito subordinados (Ricci et al., 1999; Lamarão et al., 1999; Klein \& Vasquez, 2000), com composições cálcio-alcalinas peraluminosa e metaluminosa. Ocorrem como batólitos alongados balizados e interceptados por zonas de cisalhamento NW-SE, que impõem formas sigmodais a alguns corpos. São, em geral, miloníticos e podem estar metamorfisados na fácies anfibolito inferior, mas podem preservar ainda relíquias de textura porfirítica, com feldspato tabular e plagioclásio zonado.

A ocorrência de xenólitos de ortognaisses nos granitóides da Suíte Intrusiva Creporizão indica ser esta mais nova que as rochas que compõem a Suíte Metamórfica Cuiú-Cuiú. Os granitos não deformados da Suíte Intrusiva Parauari intersectam os da Suíte Intrusiva Creporizão, indicando tratar-se de um evento magmático posterior ao que originou as rochas do Creporizão.

As rochas da Suite possuem idade de $1.974 \pm 6$ e $1.957 \pm 6 \mathrm{Ma}$ (Santos et al., 2001) e Vasquez \& Klein (2000) interpretam que estas rochas são sin- a tardi-orogênicas e Santos et al. (2001) consideram esta Suite como parte do segundo arco magmático desenvolvido na Província

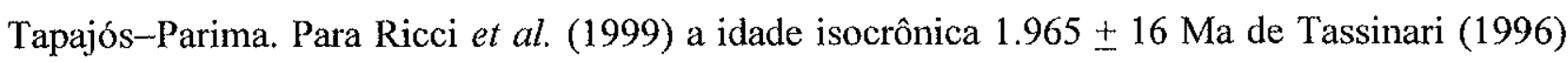
em granitos da Vila Crepori são próximas da idade $\mathrm{Pb}--\mathrm{Pb}$ e U-Pb de cristalização, o que indica que o posicionamento destes corpos foi contemporâneo à deformação em zonas de cisalhamento regionais de direção NW-SE.

Lamarão et al. (1999) dataram zircão do Granito São Jorge através do método $\mathrm{Pb}-\mathrm{Pb}$, e obtiveram idades de $1.981 \pm 2 \mathrm{Ma}$ em biotita-hornblenda granito e de $1.981 \pm 9 \mathrm{Ma}$ em biotita leuco-monzogranito, o que permite posicioná-lo cronoestratigraficamente na Suíte Intrusiva Creporizão.

A baixa razão inicial ${ }^{86} \mathrm{Sr} /{ }^{87} \mathrm{Sr}(0,7037)$ obtida por Tassinari (1996), sugere uma fonte mantélica com uma pequena contribuição crustal para as rochas dessa suite.

\section{FORMAÇÃO VILA RIOZINHO}

Esta sequiência é composta por derrames de andesito basáltico, traquiandesito basáltico, 
traquito e riolito com idades de $1.998 \pm 3$ a $2.000 \pm 4 \mathrm{Ma}$ (Lamarão et al., no prelo). Estas rochas foram anteriormente consideradas como pertencentes ao Grupo Iriri, foram individualizadas pelos autores supracitados.

\section{TONALITO RIO DAS TROPAS}

Está unidade compõe o terceiro arco magmático desenvolvido na Província e é formada predominantemente por corpos de tonalito com xenólitos de de basalto e de andesito. Associamse derrames de basalto e de andesito cálcio-alcalino com idade de $1.895 \pm 7 \mathrm{Ma}$ (Santo et al., 2001).

\section{SUITE INTRUSIVA PARAUARI}

Santos et al. (1975) introduziram a denominação de Granito Parauari para as rochas intrusivas no embasamento do Supergrupo Uatumã. Bizinella et al. (1980) consideram estas rochas como predominantemente granodioríticas, pós-cinemáticas e pré-Uatumã, posicionamento este estabelecido pela presença de intrusões do Granito Maloquinha e por estarem localmente sotopostas às vulcânicas do Grupo Iriri. A redefinição da unidade como Suíte Intrusiva Parauari deve-se a Almeida et al. (1997).

Os litotipos desta unidade são intrusivos nas rochas das unidades anteriores e são representados, em essência, por granito, monzogranito e granodiorito de granulação grossa, com tonalito e diorito subordinados. Em geral têm cor cinza-claro e são equigranulares mas, por vezes, são porfiríticos, com megacristais de plagioclásio e, localmente, de quartzo.

Santos \& Loguércio (1984) sugerem que o Granodiorito Parauari é produto da remobilização de rochas do Complexo Cuiú-Cuiú (até então considerado como Suíte Metamórfica), evidenciada por sutis gradações texturais observadas no contato entre ambas unidades, e composicionais, dadas pelos pelos teores relativamente altos de $\mathrm{Ni}, \mathrm{Cr}, \mathrm{Co}$ e $\mathrm{Cu}$, característicos de em rochas básicas primitivas, e pelas razões $\mathrm{K}_{2} \mathrm{O} / \mathrm{Na}_{2} \mathrm{O}$ e FeO/MgO.

Coutinho et al. (1998) descrevem esta suíte como granitóides cálcio-alcalinos, sin- a tardi-tectônicos, relacionados a magmas gerados nas fases iniciais de subducção até as colisionais.

Ricci et al. (1999) obtiveram idade $\mathrm{Pb}-\mathrm{Pb}$ de $1.883 \pm 2 \mathrm{Ma}$ em rochas desta suíte e Vasquez et al. (1999) de $1.893 \pm 2 \mathrm{Ma}$ para rochas correlatas. Esta Suíte é considerada por (Santos et al., 2001) como gerada no quarto arco magmático da Província e tem idades U-Pb em zircão de $1.883 \pm 4 \mathrm{Ma} \mathrm{a} 1.870 \pm 12 \mathrm{Ma} \mathrm{e} \mathrm{Pb}-\mathrm{Pb}$ em zircão de $1.880 \pm 14 \mathrm{Ma}$.

Muitos dos granitos cinzas desta Suíte, quando hidrotermalizados assumem cor vermelha intensa como, por exemplo, o Granito Batalha (Corrêa-Silva et al., 2000; Juliani et al., 2001), 
semelhante à dos granitóides da Suite Intrusiva Maloquinha.

Dada a grande variação composicional destas rochas Almeida et al. (2000) subdividiram as rochas da Suíte Intrusiva Parauari em três fácies: Granodiorítica, Granítica e Granítica com titanita e Juliani et al. (no prelo) individualizam ainda o Granito Batalha, com as seguinte características:

\subsection{Fácies Granítica}

Esta fácies é representada por batólitos de biotita monzogranito, biotita-hornblenda granodiorito, hornblenda-biotita monzogranito, álcali-feldspato granito, sienogranito, tonalito, microtonalito e micromonzogranito granofírico cálcio-alcalinos (Almeida et al., 2000). Estas rochas são leucocráticas, equigranulares e localmente porfiríticas.

\subsection{Fácies Granodiorítica}

Esta fácies ocorre como corpos isolados inseridos em rochas da fácies granítica, quais as quais apresentam contatos em geral gradacionais. É constituída por biotita granodiorito, clinopiroxênio-biotita-hornblenda granodiorito e biotita monzogranito (Almeida et al., 2000).

\subsection{Fácies Granítica com Titanita}

Esta unidade é constituída predominantemente por corpos de biotita monzogranito, hornblenda-biotita monzogranito, granodiorito e sienogranito. São rochas, em essência, equigranulares leucocráticas e de cor rosa (Almeida et al., 2000).

\subsection{Granito Batalha}

Este granito foi anteriormente considerado por Coutinho et al. (1996) como pertencente à Suíte Intrusiva Maloquinha, mas Juliani et al. (2001) e Juliani et al. (no prelo) o redefiniram como pertencente ao evento final do magmatismo Parauari, correlato ao Granito Rosa de Maio, que pertence à Fácies Granítica da Suíte.

O Granito Batalha ocorre como stocks circulares a elípticos intrusivos nos granitóides da Suíte Intrusiva Parauari e é composto por hornblenda-biotita monzogranito leucocrático com variações para sienogranito, de cor variando de cinza nas porções sem alteração hidrotermal a vermelha nas porções mais intensamente hidrotermalizadas. Localmente, apresenta texturas rapakivi e granofíricas incipientes. Quimicamente é metaluminoso a peraluminoso, cálcioalcalino a subalcalino e possui afinidade com granitos tardi- a pós-colisionais.

Santos et al. (2000) obteve idade de U-Pb por SHRIMP em zircão de $1.883 \pm 4 \mathrm{Ma} \mathrm{em}$ rochas próximas ao Granito Batalha. 


\section{SUÍTE INTRUSIVA INGARANA}

Pessoa et al. (1977) propuseram pela primeira vez a denominação Gabro Ingarana para rochas máficas-ultramáficas pré-Uatumã não metamorfisadas, posteriormente nomeadas como Suíte Intrusiva Ingarana por Quadros et al. (1999) e Bahia et al. (2000). A Suite compreende corpos de augita-gabro, leucogabro, leuconorito e hiperstênio diabásio, comumente inequigranulares, de granulação média a fina, eventualmente grossa e cor cinza-escura a esverdeada, com tendências cálcio-alcalinas e médio a alto teores de potássio (Almeida et al., 2000). Coutinho et al. (1998) descrevem ainda olivina gabro, norito e anortosito. As rochas desta unidade são intrusivas nas rochas descritas anteriormente e são cortadas por subvulcânicas e plutônicas do Supergrupo Uatumã.

Quadros et al. (1999) obtiveram idades $\mathrm{Pb}-\mathrm{Pb}$ de $1.887 \pm 3$ Ma e Santos et al. (2001) idades U-Pb em zircão entre $1.879 \pm 3$ e $1.873 \pm 10 \mathrm{Ma}$. Sulfetos de de mineralizações filonianas nas rochas desta unidade resultaram em idades $\mathrm{Pb}-\mathrm{Pb}$ entre $1.830 \pm 33 \mathrm{Ma}$ e $1.859 \pm 77 \mathrm{Ma}$ (Santos et al., 1997)

Segundo Santos et al. (2001) estas rochas fazem parte do quarto arco magmático da Província Tapajós-Parima

\section{SUPERGRUPO UATUMÃ}

O primeiro a apresentar uma descrição das rochas desta unidade foi Albuquerque (1922, em Ramgrab \& Santos, 1974), ao identificarem no rio Uatumã granitos porfiríticos e sienitos que "digeriam rochas sedimentares". Barbosa (1966, em Ramgrab \& Santos, 1974) foi o primeiro a empregar a denominação Grupo Uatumã, que na região do Tapajós seria constituído por rochas vulcânicas de andesíticas com arcóseos intercalados, além de tufos e lavas riodacíticas, diques de riolitos e ignimbritos.

Pessoa et al. (1977), Rambrab \& Santos (1974), Silva et al. (1974) Santos et al. (1975) foram os responsáveis pela caracterização e individualização das unidades deste Grupo, considerado como formado em um grande evento vulcano-plutônico anorogênico que afetou todo Cratón Amazônico.

Melo et al. (1978, em Almeida et al., 2000) elevaram a categoria do Grupo Uatumã para Supergrupo, uma vez que o conjunto engloba suítes intrusivas e extrusivas heterogêneas. Assim, o Supergrupo Uatumã passou a ser considerado como composto pela Suíte Intrusiva Maloquinha e pelo o Grupo Iriri, este subdividido nas formações Bom Jardim, Salustiano e Aruri.

Devido ao ser caráter composicional intermediário Almeida et al. (2000) propuseram que a Formação Bom Jardim fosse excluída do Supergrupo Uatumã, mas Santos et al. (2000) e Juliani et al. (no prelo) consideram a Formação Bom Jardim como uma unidade inferior do 
Grupo Iriri e geneticamente relacionada à evolução do arco magmático Parauari.

As principais características desta unidade são:

\subsection{Grupo Iriri}

O Grupo Iriri foi inicialmente denominado como Formação Iriri por Forman et al. (1972) e, posteriormente, elevado à categoria de Grupo por Pessoa et al. (1977), que o dividiu nas formações Aruri e Salustiano, e em uma seqüência híbrida sedimentar e vulcânica, posteriormente incluída na Formação Aruri (Santos et al., 2000).

Segundo Santos (1984), no Grupo Iriri predominam derrames vulcânicos cálcio-alcalinos de andesito, dacito, latito e riolito associados à camadas piroclásticas de composições semelhantes, sendo desconhecidas lavas de composição basáltica. Traquitos são também desqcritos. As piroclásticas são representadas por tufos, lápili-tufos, brechas e aglomerados vulcânicos e não haveria de sedimentos epiclásticos no Grupo Iriri.

Dall'Agnol et al. (1999) descreveram ainda a ocorrência de fayalita-hedembergita riolito aflorantes nas proximidades das cachoeiras Santa Helena e Urubuquara, no rio Jamanxim, associados a andesito e dacito do Grupo Iriri e a monzogranito da Suíte Intrusiva Parauari. Estas rochas são porfiriticas, com fenocristais de alcali-feldspato, quartzo, fayalita e hedembergita em matriz felsítica. As isócronas $\mathrm{Rb}-\mathrm{Sr}$ resultaram na idade de $1.782 \pm 51 \mathrm{Ma}$ e análises $\mathrm{U}-\mathrm{Pb}$ em $1.888 \pm 2 \mathrm{Ma}$, semelhantes às obtidas para as vulcânicas do Iriri, mas as características geoquímicas indicam que estas não pertencem à série cálcio-alcalina, confirmando, assim, como já colocado por Lamarão et al. (1999), a presença de duas séries magmáticas (cálcio-alcalina e subalcalina a alcalina) dentro da unidade conhecida como Grupo Iriri.

A grande extensão do vulcanismo Iriri no Cráton Amazônico tem sido muito discutida atualmente. Trabalhos como o de Lamarão et al. (1999) e Juliani et al. (Submetido) indicam a existência de mais de um evento vulcânico na unidade atualmente denominada Grupo Iriri, implicando que que esta unidade deve ser melhor estudada, pois vulcânicas dacíticas e andesíticas de afinidade cálcio-alcalina ou shoshonítica, mostram idade $\mathrm{Pb}-\mathrm{Pb}$ de $2.001 \pm 6 \mathrm{Ma}$, e idades $\mathrm{Pb}-\mathrm{Pb}$ de $1.877 \pm 4 \mathrm{Ma}$ em ignimbrito, de $1.890 \pm 2 \mathrm{Ma}$ em riolito e $1.880 \pm 9 \mathrm{Ma}$ em granito da região de Moraes Almeida.

As principais características de suas subunidades:

\subsubsection{Formação Bom Jardim}

A Formação Bom Jardim (Almeida et al., 2000) é composta por andesito, andesito basáltico, traquiandesito e latito, anteriormente incluidos na Formação Salustiano. Localmente apresentam textura porfirítica e amígdalas preenchidas por quartzo e carbonatos. Nunes (2001) e 
Juliani et al. (Submetido) descrevem ainda hialoclastitos, hornblenda riodacitos e corpos de brechas hidrotermais em andesitos desta unidade.

Quimicamente as rochas vulcânicas mostram afinidade cálcio-alcalina de alto potássio, variando localmente a tholeítico metaluminoso.

\subsubsection{Formação Salustiano}

A Formação Salustiano (Pessoa et al., 1977) é composta por derrames de riolito, riodacito, dacito e latito, localmente porfiríticos, e por ignimbritos e tufos diversos, comumente cortados por granitos da Suíte Intrusiva Maloquinha.

Dall'Agnol et al. (1999) obtiveram idades para os riolitos $1.888 \pm 2$ Ma por datação $\mathrm{Pb}-\mathrm{Pb}$ por evaporação de zircão, e Santos et al. (2000) de $1.870 \pm 8 \mathrm{Ma}$, por datação U-Pb SHRIMP em zircão.

Estas rochas apresentam afinidades químicas com rochas da série cálcio-alcalina de alto potássio (Bahia et al., 2000) e encontram-se hidrotermalizadas em diferentes estilos, tipos e intensidades (Nunes et al., 2000; Nunes, 2001; Corrêa-Silva et al., 2001; Juliani et al., 2001).

\subsubsection{Formação Aruri}

A Formação Aruri (Pessoa et al., 1977) é constituída por rochas piroclásticas, incluindo tufos, ignimbritos e brechas vulcânicas, e epiclásticas, com tufitos e arenitos tufáceos. Bahia et al. (2000) atribuíram a gênese destas rochas ao caráter explosivo dos magmas ácidos da Formação Salustiano, que geraram grandes quantidades de material piroclástico, que seria em parte retrabalhado e depositado em ambiente subaquático.

Esta unidade hospeda sistemas epitermais high-sulfidation mineralizado em ouro totalmente preservados (Juliani et al., 2000, 2001 e Submetido; Nunes et al., 2000 e 2001; Nunes, 2000). Corrêa-Silva et al. (2001) descreveram ainda um sistema epitermal lowsulfidation mineralizado a ouro, cobre e molibdênio hospedado nesta unidade.

Nos ignimbritos desta seqüência (Lamarão, 1999) obteve idades de $1.877 \pm 4$ Ma pelo método de evaporação $\mathrm{Pb}-\mathrm{Pb}$ em zircão.

\subsubsection{Formação Moraes de Almeida}

A Formação Moraes de Almeida é composta por fluxos de ignimbritos, lápili-tufos, riolito e traquito com idade $\mathrm{Pb}-\mathrm{Pb}$ em zircão de $1.875 \pm 4 \mathrm{Ma}$ (Lamarão et al., no prelo).

\subsection{Suíte Intrusiva Maloquinha}

Inicialmente definida por Santos et al. $(1974 ; 1975)$ como Granito Maloquinha, esta 
unidade é composta por rochas graníticas sub-vulcânicas com características ortogênicas e tendências alaskíticas, associadas ao vulcanismo ácido Uatumã. Correspondem a granitos anorogênicos e pós-colisionais associados às vulcânicas do Grupo Iriri (Almeida et al., 1999a).

A distribuição destes granitos no Cráton Amazônico e sua gênese foram descritas por Bettencourt et al. (1987 e 1995) e Dall'Agnol et al. (1994, 1997 e 1999a).

A Suíte Intrusiva Maloquinha (Almeida et al., 1977) ocorre como batólitos elípticos e circulares orientados segundo lineamentos regionais de direção NW-SE. São formados por álcali-feldspato granito, sienogranito e monzogranito leucocráticos de cor rosa a vermelha, granulação fanerítica fina a grossa, com predomínio de granulação média, textura hipidiomórfica e estrutura maciça. Suas características distintivas são a freqüente composição alaskítica, com predomínio de ortoclásio pertítico e raro microclínio, resultante de inversão de ortoclásio, e a presença comum de fenocristais subeuhédricos ou agregados de quartzo $\beta$ de cor cinza a violeta, com extinção ondulante e, menos comumente, com texturas de corrosão magmática. $\mathrm{O}$ plagioclásio é raro e, ocasionalmente é zonado. Como acessórios ocorrem fluorita associada à biotita ou a minerais opacos e/ou topázio (Brito et al., 1997).

Quimicamente são rochas peraluminosas subalcalinas e o padrão das terras raras sugerem uma evolução por fusão parcial e as características petrográficas, químicas e os modelos de distribuição dos elementos terras raras são semelhantes aos de granitos tipo A de Eby (1992).

Muito embora tenham idades semelhantes às vulcânicas, os granitos são um pouco mais novos, pois cortam as vulcânicas em algumas regiões. A idade $\mathrm{Rb}-\mathrm{Sr}$ de $1.840 \pm 26 \mathrm{Ma}$ indica que os granitos compõem o final do evento magmático Uatumã (Santos et al., 1997), e Vasquez et al. (1999) obtiveram idade $\mathrm{Pb}-\mathrm{Pb}$ de $1.882 \pm 4 \mathrm{Ma}$ em sienogranito de um batólito da Suíte Maloquinha e $1.888 \pm 2 \mathrm{Ma}$ para um riodacito do Grupo Iriri. Santos et al. (1999) obtiveram idades ao redor de 1.870 Ma pelo método U-Pb em zircão.

Brito (1999) dividiu as rochas dessa unidade em três fácies: biotita-granitos, hornblendagranitos e riebeckita granitos, sendo as duas primeiras mais abundantes.

\subsubsection{Fácies com biotita}

Nas rochas desta fácies a biotita é o único mineral máfico presente, são leucocráticas a alaskíticas e cor variando de rosa a vermelho. A granulação varia de fina a grossa, predominando os tipos grosso, são hipidiomórficos, inequigranulares, por vezes com megacristais de feldspato potássico e quartzo violeta. Não raramente ocorrequartzo bipiramidal, cavidades miarolíticas e texturas granofíricas. Como acessórios estão presentes zircão, opacos, apatita e allanita e como minerais secundários ocorrem biotita verde, clorita, prehnita, sericita, fluorita e topázio (Almeida et al., 2000; Bahia \& Quadros, 2000). 
Sua composição varia de sienogranito a monzogranito, com raras ocorrências de álcalifeldspato granito subalcalinos a alcalinos fracamente peraluminosos. (Almeida et al., 2000; Bahia \& Quadros, 2000).

\subsubsection{Fácies com anfibólio e biotita}

Ocorrem mais raramente, formando stocks de rochas de cor cinza esverdeado a rosaavermelhado, leucocráticas, faneríticas finas a grossas, inequigranular a porfirítica, com megacristais de feldspato potássico e de quartzo bipiramidado e, localmente, texturas granofíricas.

A composição predominante é sienogranítica e monzogranítica, com hornblenda e biotita como minerais máficos, além de apatita, zircão e allanita acessórios e prehnita, epidoto, fluorita, clorita, saussurita, argilo-minerais e hidróxidos de ferro secundários. $\mathrm{O}$ anfibólio tem cor verdeazulada a marrom-esverdeada.

Estas rochas possuem caráter medianamente peraluminoso, são subalcalinas e são quimicamente semelhantes aos granitos de tipo A de Eby (1992).

\section{GRANITO CAROÇAL}

O Granito Caroçal foi distinguido dos granitos Maloquinha por Almeida et al. (1999a) devido às suas caracterísiticas quimicas. São subalcalinos, mas possuem afinidades com rochas cálcio-alcalinas de alto potássio e apresentam padrão de ETR distinto daqueles típicos dos granitos Maloquinha. Apresentam textura fanerítica grossa equigranular a porfirítica, com ortoclásio ovóide e tabular, são leucocráticos e são compostos por ortoclásio micropertítico, quartzo, com titanita, zircão, apatita, allanita, epidoto e opacos como acessórios. Como minerais secundários ocorrem clorita, prehnita, fluorita e sericita.

Sua idade U-Pb SHRIMP em zircão é de 2,6 a 2,7 Ga nos núcleos dos cristais de 1,87 Ga nas bordas, esta interpretada como a idade da magmatismo (Santos, 1999, em Almeida et al., 1999).

Almeida et al. (1999a) consideram que as idades modelo $\mathrm{Sm}-\mathrm{Nd}\left(\varepsilon_{\mathrm{Nd}}=-0,7 \mathrm{a}-10,2\right)$ entre 2,24 e 2,85 Ga obtidas por Sato \& Tassinari (1997) indicam que a Suíte Intrusiva Maloquinha tem como origem uma crosta continental arqueana.

\section{LAMPRÓFIRO JAMANXIM}

Estes lamprófiros ocorrem como diques encaixados nas rochas do Grupo Iriri, da Suíte Intrusiva Ingarana e Suíte Intrusiva Parauari. São formados por rochas glomeroporfiríticas, com matriz afanítica a faneítica fina, meso a melanocráticas, predominando a variedade vogesítica 
sobre a espessartítica (Bahia \& Quadros, 2000).

Para estas rochas Almeida et al. (1978) obtiveram idade K-Ar em rocha de $1.536 \pm 31$ Ma.

\section{FORMAÇÃO BUIUÇU}

A Formação Buiuçu (Pinheiro \& Ferreira, 1999) é constituída predominantemente por arenito e arenito arcoseano, além de conglomerado, siltito, argilito, tufos e tufitos. Ocorre sob a forma de cristas alongadas, falésias e platôs com estratificação plano paralela, localmente cruzada e com marcas onduladas (Almeida et al., 2000). A idade máxima desta unidade, e a das vulcânicas ácidas do Grupo Iriri, já que encontram-se seixos desta unidade em conglomerados e sua idade mínima é dada pela idade dos diques de Diabásio Crepori nela introduzidos (Almeida et al., 2000).

\section{DIABÁSIO CREPORI}

Esta unidade foi originalmente denominada como Sill Crepori por Pessoa et al. (1977) e posteriormente renomeada por Santos et al. (1984) como Diabásio Crepori ou omo Suíte Intrusiva Crepori por Santos et al. (1999). Segundo Quadros et al. (1999), esta unidade ocorre como diques subverticais com espessuras que variam de 10 a $500 \mathrm{~m}$, e sills, constituídos por augita diabásio, geralmente com granulação fina a afanítica e, subordinadamente, olivina diabásio e microgabro, que formam .

Para estas rochas Santos et al. (2000) obteve idade $1.778 \pm 9$ U-Pb SHRIMP em baddeleyita.

\section{SUITE INTRUSIVA CACHOEIRA SECA}

As rochas básicas aflorantes no médio curso do rio Tocantins foram inicialmente denominadas por Pessoa et al. (1977) como troctólito Cachoeira Seca e renomeadas Suíte Intrusiva Cachoeira Seca por Quadros et al. (1998).

Esta suíte é composta por diques predominantemente formados por olivina gabro e diorito e, subordinadamente por troctolito e diabásio troctolito com idade $\mathrm{K}$-Ar em plagioclásio variando de $1.046 \pm 50$ a $1.072 \pm 18 \mathrm{Ma}$ (Pessoa et al.,1977) e de 1.042 a 1.090 Ma por Santos et al. (1997).

\section{ROCHAS BÁSICAS INDIFERENCIADAS}

Quadros et al. (1999) utilizaram esse termo ao se referirem a uma série de rochas básicas, cujas informações ainda são insuficientes para agrupa-las como unidade ou estabelecer 
correlações. Compreendem olivina basalto, microgabro, olivina diabásio, augita diabásio e lamprófiros que seccionam as unidades anteriores.

Incluí-se também nessa unidade os diques básicos mesozóicos que ocorrem na porção meridional do Cráton Amazônico, denominados, com base apenas nas suas localizações geográficas como Penatecaua (Issler et al., 1974), Periquito (Bizinella et al., 1980), Cururu (Silva et al., 1974).

As idades $\mathrm{K}-\mathrm{Ar}$ variam de $134 \pm 4 \mathrm{Ma}$ a $222 \pm 3 \mathrm{Ma}$ (Santos \& Loguércio, 1984), sendo que Santos et al. (1999) caracterizam idades K-Ar de $148 \pm 6 \mathrm{Ma}, 179 \pm 3 \mathrm{Ma}$ e $180 \pm 9 \mathrm{Ma}$ para os diabásios Piriquito e Cururu.

Santos et al. (1999) descreveram ainda um enxame de diques com $300 \mathrm{~km}$ de extensão, com direção NNE-SSW, que atravessam o Rio Tapajós na região de Jacareacanga, com idade $\mathrm{U}-\mathrm{Pb}$ concordante em baddeleyita de $514 \pm 15 \mathrm{Ma}$.

\section{COBERTURAS FANEROZÓICAS}

Inclui-se nesta unidade as coberturas sedimentares mais novas que $590 \mathrm{Ma}$, (Coutinho et al., 1997; Vasquez et al., 1996).

Na região do Tapajós, o Paleozóico está representado pela Bacia do Tapajós (formações Jatuarana e Ipixuna), o Mesozóico pela Formação Alter do Chão (seqüência de topo da Bacia Amazônica) e o Cenozóico por coberturas lateríticas terciárias, sedimentares fluviais e aluvionares pleistocênicas (Faraco et al., 1997).

Sedimentos clásticos, lateritas, alúvios e colúvios são também englobados nesta unidade.

Estas coberturas são importantes depósitos de ouro na Província, notadamente os aluviões e coluviões, onde a atividade garimpeira foi responsável por grande parte da produção de ouro da região. 


\title{
CAPÍtULO III
}

(Anexo I)

\section{PALEOPROTEROZOIC HIGH-SULFIDATION MINERALIZATION IN THE TAPAJÓS GOLD PROVINCE, AMAZONIAN CRATON, BRAZIL: GEOLOGY, MINERALOGY, ALUNITE ARGON AGE AND STABLE ISO'TOPE CONSTRAINTS}

\begin{abstract}
The Brazilian Tapajós Gold Province contains the first evidence of high-sulfidation gold mineralization in the Amazonian Craton and probably is related to large nested ash-flow calderas. The gold province is in the Tapajos-Parima (or Ventuari-Tapajós) Province composed of a metamorphic, igneous, and sedimentary sequence generated during a 2.10 to 1.87 Ga ocean-continent orogeny.
\end{abstract}

The high-sulfidation mineralization with magmatic hydrothermal alunite is related to hydrothermal breccias hosted in a rhyolitic volcanic ring complex that contains granitic stocks ranging in age from 1.87 to $1.89 \mathrm{Ga}$. Cone-shaped hydrothermal breccias that flare upwards contain vuggy silica and have an overlying brecciated massive silica cap that occurs in the uppermost part of a ring structure volcanic cone. Drill cores of one of the hydrothermal breccias contain alunite, natroalunite, pyrophyllite, andalusite, quartz, rutile, diaspore, woodhouseite-svanbergite, kaolinite and pyrite along with inclusions of enargite-luzonite, chalcopyrite, bornite and covellite. The siliceous core of this alteration center is surrounded by advanced argillic and argillic alteration zones that grade outward into large areas of propylitically altered rocks with sericitic alteration at depth. Several occurrences and generations of alunite are observed. Alunite is disseminated in the advanced argillic haloes that envelop massive and vuggy silica or that underlies the brecciated silica cap. Coarse-grained alunite also occurs in branching veins and locally is partially replaced by a later generation of fine-grained alunite. Silicified rocks associated with the alunite contain up to $4.5 \mathrm{ppm}$ of gold. Seven alunite samples give ${ }^{40} \mathrm{Ar}{ }^{39} \mathrm{Ar}$ ages of $1.846 \pm 0.002$ to $1.869 \pm .002 \mathrm{Ga}$ with varying degrees of apparent minor argon loss. Stable isotope data require a magmatic hydrothermal origin for the alunite, the type typically associated with high-sulfidation mineralization. $\delta^{34} S$ values of most alunites range from 18.1 to 36.9 permil. Sulfur isotope alunitepyrite and oxygen isotope alunite $\mathrm{SO}_{4}-\mathrm{OH}$ temperatures range from 130 to $420{ }^{\circ} \mathrm{C} . \delta D_{\mathrm{H} 2 \mathrm{O}}$ and $\delta^{8} \mathrm{O}_{\mathrm{H} 2 \mathrm{O}}$ for alunite hydrothermal fluids suggest the predominance of magmatic water, with a small meteoric contribution. A rare sample of supergene alunite has a $\delta^{34} S$ value of 4.1 permil and an ${ }^{40} \mathrm{Ar}{ }^{39} \mathrm{Ar}$ age of $51.3 \pm 0.1 \mathrm{Ma}$. Other than regional foliation in the volcanic rocks and local foliation of alunite, the mineralization and associated alteration appears remarkably little disturbed by later 
metamorphism and supergene alteration. The gold mineralization was preserved because of burial by sediments and tuffs in taphrogenic (pull apart) basins that were probably first exhumed about $60 \mathrm{Ma}$. Since high-sulfidation mineralization forms at relatively shallow crustal levels, the Tapajós Province discoveries provide new perspectives for mineral exploration for the Amazonian and perhaps for other Precambrian cratons.

\section{Introduction}

High-sulfidation epithermal mineralization (Hedenquist, 1987), also known as highsulfur (Bonham, 1984), quartzalunite (Berger, 1986), acid sulfate (Heald et al., 1987) or alunitekaolinite mineralization (Berger and Henley, 1989) occurs in shallow crustal environments that favor weathering and rapid erosion. As a consequence, high-sulfidation mineral occurrences are typically preserved in Tertiary-Quaternary terrains (Arribas Jr., 1995), and rarely in Cretaceous (So et al., 1998; Nelson, 2000), Paleozoic (Thompson et al., 1986), and Neoproterozic terrains (Dubé et al., 1995; Ayuso et al., in press). One highly metamorphosed Paleoproterozoic deposit in Sweden has been interpreted as high-sulfidation type mineralization (Hallberg, 1994), but well-preserved and unmetamorphosed examples older than Neoproterozoic have not been documented previously.

Recent studies (Jacobi, 1999; Nunes at al., 2000; Juliani et al., 2000) reveal the existence of several weakly deformed and unmetamorphosed high-sulfidation mineralized systems in the Tapajós Gold Province (Fig. 1) related to large caldera complexes. These are mineralized hydrothermal breccias in small post-caldera ring composite volcanoes associated with epizonal porphyry intrusions. In one of these occurrences, hydrothermal alteration zoning is characterized by extensive silicification, pyrophyllitization, and alunitization in and around shallow hydrothermal breccias. The distal and deeper alteration zones are propylitic and sericitic.

Gold, as well as enargiteluzonite and covellite, is associated with these altered rocks. Occurrences such as these may have been a source of gold for alluvial and colluvial gold deposits, which were responsible for ca. 225 tons (official production; Faraco et al., 1997) or over than 900 tons (unofficial production; Santos et al., 2001) of gold in garimpos (small mining operations undertaken by prospectors) in the Tapajós Gold Province until 1997.

The Tapajós Province is still undergoing exploration and many details of the geology are not understood. Magmatic hydrothermal alunite (Rye et al., 1992) invariably accompanies highsulfidation mineralization and a great deal can be learned about the mineralization from a study of this alunite. In this paper, we describe the geologic setting of the occurrences and the mineralogy, argon age, and stable isotope geochemistry of alunite from a single high-sulfidation occurrence. This paper presents documentation of a well-preserved Paleoproterozic high- 
sulfidation mineral occurrence in the Tapajós Gold Province, the first discovery of such an occurrence in the Amazonian Craton. Despite the poor quality of outcrops due to the aggressive tropical climate and dense rainforest, and the existence of few exploratory drill holes, the highsulfidation nature of the mineralization at Tapajós can be clearly established.

\section{Geological setting}

The Tapajós Gold Province (Fig. 1) covers about $140,000 \mathrm{~km}^{2}$ in the southern Amazonian Craton (Almeida et al., 1981). A summary of major stratigraphic units and their geochronology and tectonic setting is given in Table 1 and Fig. 2. For more details the reader is referred to papers referenced in Table 1.

The Tapajós Gold Province was formed shortly after the $\sim 2.10-1.87$ Ga TapajósParima (Santos et al., 2000) or Ventuari-Tapajós (Tassinari and Macambira, 1999) orogenic event, which produced a well-dated sequence of metamorphic, igneous, and sedimentary rocks. An ocean-continent collisional orogeny associated with eastward shallow-dipping subduction at $\sim 1.9 \mathrm{Ga}$ resulted in the construction of the Parauari magmatic arc (Santos et al., 2000) followed by intermediate to acid volcanism of the Iriri Group (Table 1) and late- to post-collisional granite intrusions. The Iriri acid volcanic sequence, which is cut by epizonal granitic porphyry stocks and dikes, hosts the high-sulfidation mineral occurrences.

Mafic magmatic episodes about $1.89 \mathrm{Ga}, 1.78 \mathrm{Ga}$ and $1.1 \mathrm{Ga}$, and minor lamprophyre dikes with ages varying from 514 to $134 \mathrm{Ma}$, are in the Tapajós Gold Province (Table 1; Quadros et al., 1999; Almeida et al., 2000; Bahia and Quadros, 2000; Ferreira et al, 2000; Klein and Vasquez, 2000; Santos et al., 2000; Vasquez and Klein, 2000). As will be discussed, the apparent argon loss exhibited by some of the alunite age spectra may have resulted from some of these later events. 
Table 1. Main geological units and geochronology of the Tapajós Gold Province

\begin{tabular}{|c|c|c|c|c|c|}
\hline Geological units & Lithology & Age (Ga) & Method & Tectonic setting & References \\
\hline Phanerozoic cover & Clastic sedimentary rocks, laterite and alluvia & - & $-1-$ & Intracratonic & (6) (11) \\
\hline $\begin{array}{l}\text { Cachoeira Seca Intrusive } \\
\text { Suite }\end{array}$ & $\begin{array}{l}\text { Subalkaline to tholeiitic olivine gabbro, diorite, troctolites and } \\
\text { diabase }\end{array}$ & $1.186 \pm 0.015$ & SHRMP U-Pb baddeleyite & Intracratonic & $\frac{(0)(11)}{(7)}$ \\
\hline Crepori Diabase & Tholeiitic augite diabase and olivine diabase & $1.778 \pm 0.009$ & SHRIMP U-Pb baddeleyite & Intracratonic & (6) (7) \\
\hline Buiuçu Formation & $\begin{array}{l}\text { Feldspathic sandstone, sandstone, arkose, conglomerate, } \\
\text { argillite, siltite and acid tuffs }\end{array}$ & - & - & Taphrogenic basin & (11) \\
\hline \multicolumn{6}{|l|}{ Latumã Supergroup } \\
\hline Maloquinha Granite & $\begin{array}{l}\text { Subvolcanic subalkaline to alkaline biotite-hornblende alkali- } \\
\text { feldspar granite, syenogranite monzogranite and riebeckite- } \\
\text { arfvedsonite, micro-monzonites with rapakivi textures }\end{array}$ & 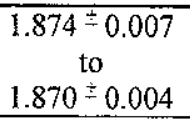 & SHRIMP U-Pb zircon & $\begin{array}{l}\text { Post-collisional and } \\
\text { anorogenic }\end{array}$ & $(1)(2)(6)(9)(11)$ \\
\hline Iriri Group & & & & & $(3)(6)(7)$ \\
\hline Aruri Formation & Ash flow tuffs, breccias and tuffaceous sandstones & $1.877 \pm 0.004$ & $\mathrm{~Pb}-\mathrm{Pb}$ zircon evaporation & Late- to post-orogenic & $\begin{array}{l}(2)(6)(7)(8)(9) \\
(11)\end{array}$ \\
\hline Salustiano Formation & $\begin{array}{l}\text { Rhyoliteic rhyodacitic, dacitic, volcaniclastic rocks and } \\
\text { fayalite-hedenbergite thyolites }\end{array}$ & $\begin{array}{l}1.870 \pm 0.008 \\
1.890 \pm 0.002\end{array}$ & $\begin{array}{l}\text { SHRIMP U-Pb zircon } \\
\mathrm{Pb}-\mathrm{Pb} \text { zircon evaporation }\end{array}$ & Late- to post-orogenic & $(6)(7)(8)(9)(11)$ \\
\hline Bom Jardim Formation & $\begin{array}{l}\text { Andesite, dacite, trachyandesite and latite, with subordinate } \\
\text { rhyolitic and basaltic flows and volcaniclastic rocks }\end{array}$ & $\begin{array}{l}1.888 \pm 0.007 \\
1.893 \pm 0.005 \\
2.001 \pm 0.006\end{array}$ & $\mathrm{~Pb}-\mathrm{Pb}$ zircon evaporation & Late- to post-orogenic & $(6)(7)(8)(9)(11)$ \\
\hline $\begin{array}{l}\text { Rosa de Maio and Batalha } \\
\text { granites }\end{array}$ & Calc-alkaline hornblende-biotite and biotite granites & $\begin{array}{l}1.879 \pm 0.011 \\
1.883 \pm 0.004\end{array}$ & $\begin{array}{l}\text { U-Pb zircon } \\
\text { SHRIMP U-Pb zircon }\end{array}$ & $\begin{array}{l}\text { Late- to post Parauari } \\
\text { magmatic arc (M) }\end{array}$ & $(10)$ \\
\hline Ingarana Intrusive Suite & $\begin{array}{l}\text { Subalkaline olivine gabbro, augite gabbro, norite, anorthosite } \\
\text { and ferrosilite diabase }\end{array}$ & $1.893^{ \pm} 0.003$ & SHRIMP U-Pb zircon & $\begin{array}{l}\text { Parauari arc basic } \\
\text { magmatism }\end{array}$ & (4) \\
\hline Parauari Intrusive Suite & $\begin{array}{l}\text { Porphyritic homblende-biotite monzogranite, granodiorite, } \\
\text { syeno-granite and tonalite }\end{array}$ & $\begin{array}{l}1.897 \div 0.006 \\
1.883 \pm 0.002\end{array}$ & $\begin{array}{l}\text { U-Pb zircon } \\
\mathrm{Pb}-\mathrm{Pb} \text { zircon }\end{array}$ & $\begin{array}{l}\text { Calc-alkaline magmatic } \\
\operatorname{arc}(\mathrm{II})\end{array}$ & $(4)(5)(6)(10)$ \\
\hline $\begin{array}{l}\text { Abacaxis and Sequeiro } \\
\text { Formations }\end{array}$ & Pinkish siltstones, sandstone and claystone and quartz-wackes & $\begin{array}{c}1.895^{ \pm 0} 0.009 \\
\text { to } \sim 1.900\end{array}$ & U-Pb zircon & $\begin{array}{l}\text { Parauari fore- and back- } \\
\text { arc (II) basins }\end{array}$ & $(6)(10)$ \\
\hline Creporizão Intrusive Suite & $\begin{array}{l}\text { Metamorphosed porphyritic syeno- and monzogranites, } \\
\text { granodiorite and tonalite }\end{array}$ & $\begin{array}{l}1.968 \pm 0.019 \\
1.897 \div 0.006\end{array}$ & $\begin{array}{l}\mathrm{Pb}-\mathrm{Pb} \\
\mathrm{U}-\mathrm{Pb}\end{array}$ & Late-magmatic arc (D) & $(5)(11)$ \\
\hline Cuiú-Cuiú Complex & $\begin{array}{l}\text { Granodioritic to tonalitic gneisses, mignatites and } \\
\text { amphibolite enclaves }\end{array}$ & $2.011 \div 0.023$ & U-Pb zircon & $\begin{array}{l}\text { Calc-alkaline magmatic } \\
\operatorname{arc}(\mathrm{I})\end{array}$ & $(7)(8)(10)(13)$ \\
\hline Jacareacanga Group & $\begin{array}{l}\text { Phyllite, schists, metaturbidite, quartzite, metabasite, and BFF } \\
\text { (low- to medium-metamorphic grade) }\end{array}$ & $\begin{array}{l}2.125 \text { to } \\
2.106\end{array}$ & U-Pb detrital zircon & Trench basin & $(8)(10)(11)$ \\
\hline
\end{tabular}

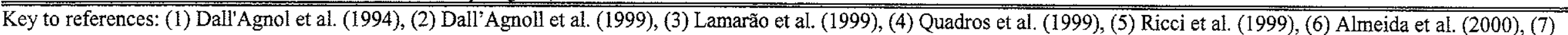
Bahia and Quadros (2000), (8) Ferreira et al. (2000), (9) Klein and Vasquez (2000), (10) Santos et al. (2000), (13) Vasquez and Klein (2000). 


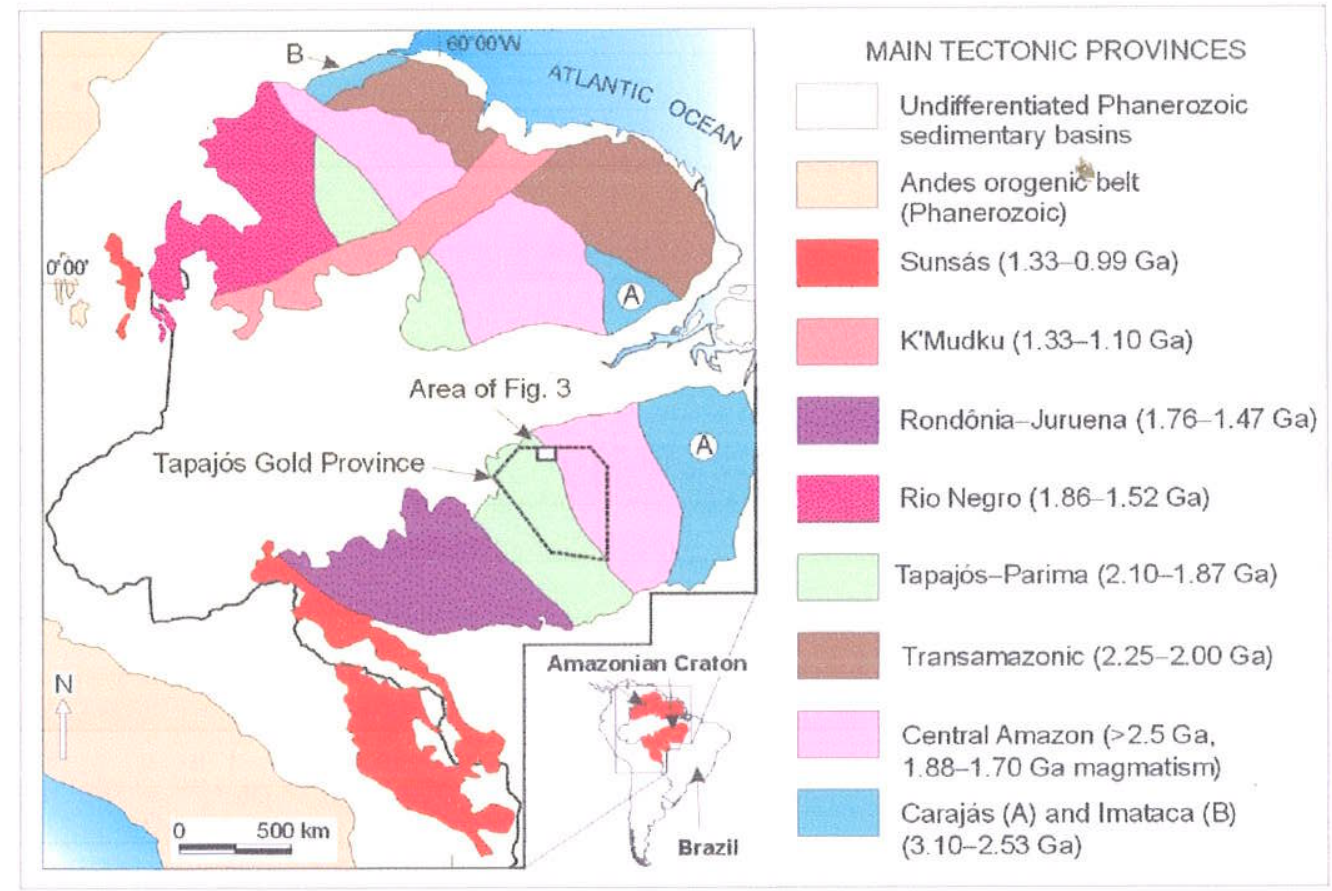

Fig. 1. Location of the Tapajós Gold Province and the main geochronological-tectonic provinces of Amazonian Craton, according to Santos et al. (2000). Location of Fig. 3 outlined.

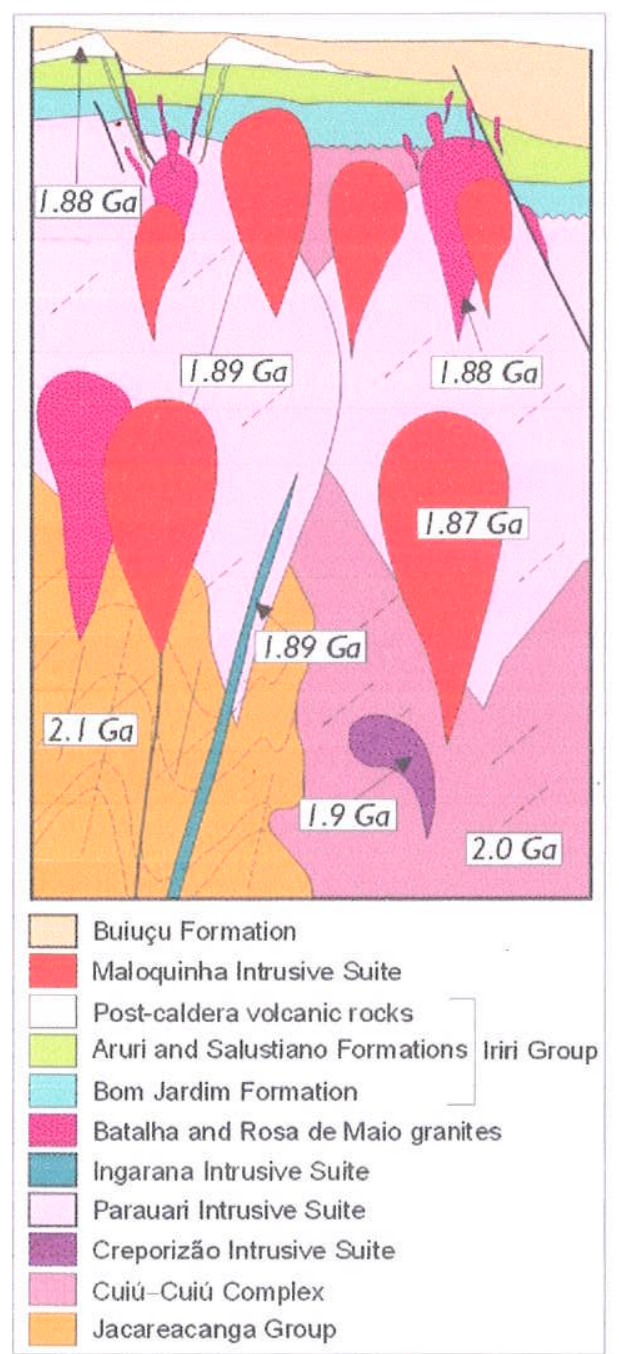

Fig. 2. Schematic stratigraphic column of the main units of the Tapajós Gold Province (Juliani et al., submitted). 
Proterozoic taphrogenic basins containing fluvial to shallow marine sequences of the Buiuçu Formation overlie the volcanic rocks and coeval granites (Bezerra, 1984; Faraco et al., 1997). Paleozoic and Cenozoic sedimentary sequences covered much of the Amazonian Craton. Miocene-Pliocene and Quatenary laterization events are recognized in the southern Amazonian Craton (Faraco et al., 1997; Motta et al., 2000). Recent alluvial and colluvial deposits, commonly containing placer gold, are the youngest units in the region.

\section{Analytical Methods}

Petrologic, textural, and mineralogical studies were carried out using transmitted- and reflected-light optical microscopy. The mineralogical characterization and identification was further detailed using a LEO S440 scanning electron microscope, coupled to a LINK ISIS L300 dispersion microanalysis system, with a Pentafet SiLi detector, ATW II ultrafine window, of 133 $\mathrm{eV}$ to $5.9 \mathrm{keV}$ resolution and $20 \mathrm{kV}$ acceleration voltage. The samples were carbon coated and the images were acquired by the backscattered-electron detector using a cobalt standard for calibration of the semi-quantitative EDS analyses. Alunite analyses were carried out using a JEOL JXA 8600 electron microprobe, using $5 \mathrm{nA}$ as sample current, $15 \mathrm{KV}$ as accelerating voltage and a beam diameter of $10 \mu \mathrm{m}$. The electron microprobe data on alunite is given in Table 2. XRD identifications were carried out using a copper-tube SIEMENS D5000 diffractometer. The hydrothermal alteration minerals in drill core samples were also identified by an Integrated Spectronics G8630 PIMA (Portable Infrared Mineral Analyzer).

Alunite from surface and drill core samples were dated by the ${ }^{40} \mathrm{Ar} /{ }^{39} \mathrm{Ar}$ incremental heating method following procedures outlined by Snee (in press). The alunite are both coarse and fine-grained and some have minor $(<1 \%$ ) inclusions of fine-grained pyrite. Eight to 12 milligrams of each alunite were irradiated in quartz vials for 30 to 129 hours at $1 \mathrm{MW}$ in the central thimble of the U.S. Geological Survey research reactor. Three of the alunite were irradiated in vacuum-evacuated capsules to capture potentially recoiled argon isotopes; one sample, FV1-1/16, was irradiated and analyzed twice. Neutron fluence during irradiation was monitored by hornblende standard MMhb-1, which has a KAr age of $523.1 \pm 1.7 \mathrm{Ma}$ (Renne et al., 1998). After irradiation, the vacuum-evacuated quartz vials were opened under vacuum and the contents of the vial were analyzed to determine whether any argon was released from the sample during irradiation. No ${ }^{40} \mathrm{Ar}$ and 1 part in $500{ }^{39} \mathrm{Ar}$, even for fine-grained ( 10micrometers diameter) samples, were lost into the vacuum during irradiation. Subsequently the samples were progressively degassed in a double-vacuum resistance furnace in a series of 8 to 17 20-minute-long heating steps to a maximum of $1350^{\circ} \mathrm{C}$ with the majority of the argon being released between 550 and $725^{\circ} \mathrm{C}$, although one samples released its argon between 700 and 950 
${ }^{\circ} \mathrm{C}$. Apparent ages for each step were calculated using decay constants of Steiger and Jäger (1977). The argon data are presented in Table 3 with detailed analytical procedures given in the footnotes of Table 3 .

For stable isotope analyses of alunite and pyrite, pure separates were obtained by hand picking. $\delta^{34} \mathrm{~S}$ and $\delta^{18} \mathrm{O}$ of the alunite $\mathrm{SO}_{4}$ site and the $\delta \mathrm{D}$ and $\delta^{18} \mathrm{O}$ of the alunite $\mathrm{OH}$ site were determined using the techniques described by Wasserman et al. (1992). Sulfur isotopic composition of pyrite was analyzed using continuous flow techniques. The stable isotope data are summarized in Table 4.

\section{Results and analyses}

\subsection{Regional geologic structures}

The regional geologic structures were identified through TM-LANDSAT 5 digital images and using paper copies of aerial RADAMBRASIL Project radar images. Regional geologic structures identified from remote sensing products within the Tapajós Gold Province are shown in Fig. 3.

In this figure large circular structures are identified, which along with supporting geologic studies are interpreted to be nested and overlapping ash-flow calderas up to $20-\mathrm{km}$ diameter. Some of these calderas have smaller circular structures that are related to small, dacitic to rhyodacitic epizonal porphyry stocks. Others features are interpreted to be intracaldera resurgent domes or small composite volcanoes. Several semi-eroded post-collapse rhyolitic volcanic vents or domes are present along ring structures of some large ash-flow calderas (Fig. 3). Circular structures representing epizonal stocks are also common in the caldera ring structure complexes. The geologic map of the rectangle area in Fig. 3 is shown in Fig. 4.

\subsection{Geologic setting of the high-sulfidation mineralization}

Three main volcanic-related sequences of the Iriri Group (Bom Jardim, Salustiano and Aruri formations) and a post-caldera volcanic unit, identified in this study, overlie the syntectonic magmatic arc-related Parauari granites (Table 1, Figs. 3 and 4). The volcanic stratigraphy of the Tapajós Gold Province is not well established and the correlation of these units with caldera evolution is only beginning (Juliani et al., 2000; Corrêa-Silva, 2002). On this new focus, the lower unit (Bom Jardim Formation) is composed mainly of pre-collapse andesitic and dacitic flow and tuff deposits. The middle unit includes the Salustiano and Aruri Formations that are composed of rhyolitic flows, ash-flow tuffs and rhyolitic epiclastic volcanics associated with the caldera formation. Post-caldera volcanism is represented by small rhyolitic composite ring volcanoes (with radiating lava flows and welded tuffs), and domes (Figs. 3 and 4), which 
host high-sulfidation epithermal mineral occurrences. Intracaldera deposits are represented by ash-flow tuffs, epiclastic tuffs, arenites, mudstones, and silicified layers. Granophyric dacitic to rhyolitic epizonal stocks and dikes crosscut the volcano-sedimentary sequence.

The supracrustal and intrusive rocks are deformed along brittle or brittle-ductile shear zones, and large undulations, with rare weak axial-plane foliation are observed in volcanic epiclastic and sedimentary rocks. Extensive hydrothermal alteration haloes mask the effect of regional metamorphism. Sericite is observed in axial-planes associated with regional undulations.

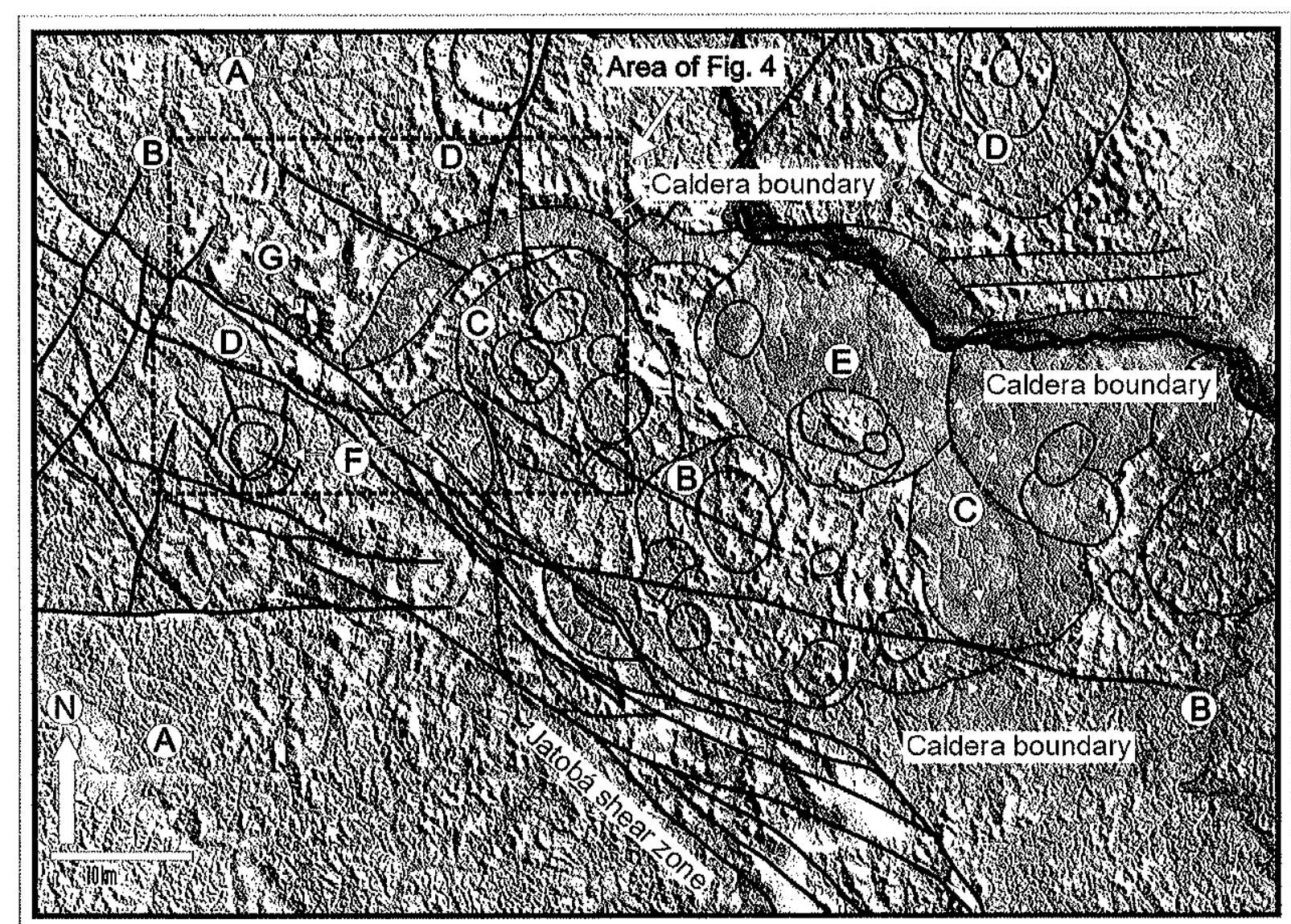
(A) Basement of the volcanic sequence, mainly syn-collisional Parauari granites
(B) Pre-caldera outflow volcanic rocks, including intermediate-composition rocks of the Bom Jardim Formation and caldera-related acid-composition volcanic rocks and tuff deposits of the Salustiano and Aruri Formations
(C) Intra-caldera deposits
(D) Post-caldera ring volcanic composite volcanoes and possible domes
(E) Resurgent volcanic dome
(F) Late to post-collisional epizonal Parauari granites
(G) Rhyolitic to rhyodacitic porphyry stocks
Faults

Fig. 3. PC1, TM-LANDSAT Image with interpreted ring structures associated with the collapse of ashflow calderas and crosscutting circular granite, granophyre and porphyry intrusions. The interpretations are based on observations of rocks during geologic mapping. The dashed rectangle delimits the area of Fig. 4. 
A diagrammatic cross section essential to understanding the geologic framework of a typical high-sulfidation mineral occurrence in the Tapajós Gold Province is shown in Fig. 5. The important units in this cross section are discussed below.

\subsubsection{Basement}

The basement for the volcanic and volcaniclastic rocks of the Iriri Group is well exposed at the southern part of the Jatobá shear zone (Figs. 3 and 4), where the supracrustal rocks are almost completely eroded. It is represented by syn-collisional calc-alkaline batholithic granitic bodies of the $\sim 1.9 \mathrm{Ga}$ Parauari Intrusive Suite (Santos et al., 2000). Light pink to gray biotiteand hornblende-bearing foliated granodiorite predominates, with subordinate monzogranite and tonalite. These rocks are medium- to fine-grained, equigranular to porphyritic and are intruded by aplite, diabase, and gabbroic dikes.

\subsubsection{Pre-caldera volcanism}

Pre-caldera volcanism is represented by the Bom Jardim Formation $(2.00-1.89 \mathrm{Ga}$; Table 1), which overlies the granitic basement. It is composed predominantly of calc-alkaline andesite and dacite, commonly porphyritic, and volcaniclastic rocks. Rhyolitic lavas and tuffs, amygdaloidal basalt and tachylyte flows are also present. Basaltic or andesitic intrusive hydrothermal breccias are occur locally. This formation appears to represent the eroded remains of pre-collapse clustered stratovolcanoes of intermediate composition associated with back-arc rifts related to the Parauari subduction.

\subsubsection{Caldera-related volcanism}

The caldera-forming deposits are represented by large intracaldera and outflow sheets of ash flow tuffs and acid volcanic rocks of the Salustiano and Aruri Formations $\left(1.89^{-} 1.87 \mathrm{Ga}\right.$; Table 1), which overly the Bom Jardim Formation. The volcaniclastic rocks are composed of rhyolitic ash flow tuffs, crystal tuff, welded tuffs, lapilli-stones, and volcanic agglomerates, with minor dacitic ash-flow tuffs. The rhyolites have an aphanitic or vitreous matrix and commonly amygdules and flux structures. Flows of hyaloclastite and epiclastic volcanic rocks are also present.

\subsubsection{Intracaldera deposits}

The basal intracaldera deposits are composed mainly of ash-flow tuff, volcanic flow breccia and agglomerate, and minor rhyolite flows, hyaloclastite, epiclastic tuff, arkose and arenite. This sequence grades upward into feldspathic and lithic sandstones with abundant beds 
of arkose and siltstone, and minor conglomerate, sedimentary breccia, and mudstone. Locally also occur chert, carbonaceous-, and sulfide-rich layers. The sedimentary structures and lithotypes indicate a depositional environment in part related to alluvial and lacustrine settings.

\subsubsection{Post-caldera volcanism}

The post-caldera volcanic units, which host the high-sulfidation mineral occurrences, occur as vents along rings (Fig. 4) and within calderas (Fig. 3). Few of these volcanic structures were studied and the rocks are poorly exposed, which makes it difficult to classify them. A few exploration drill holes in one of thesevolcanic ring structures show interbedded acid and intermediate-composition flows, and welded tuffs, which indicates a similarity to composite volcanoes. However, the landforms of other of these structures are similar to those of ring and intracaldera resurgent domes.

The volcanic sequence contains, at the base, discontinuous massive or banded finegrained dacite and dacitic ash-flow tuff flows. These rocks are overlain by layered rhyolitic tuffs, rhyolitic to dacitic lapilli-tuff, lapillistone, welded tuffs, ash flow-tuffs and pyroclastic breccia. Ellipsoidal dacite bombs with trachytic texture were found in the rhyolitic tuff pile. Annular and radial fractures are associated with upward flaring cone-shaped bodies of hydrothermal breccias with intensely flow-oriented matrix and rounded fragments. Close to the hydrothermal breccias, the tuffs are hydraulically fractured. On top of the semi-eroded volcanic cones, the explosive hydrothermal breccia bodies are covered by a massive hematite-rich and vuggy silica cap, which is cut by explosive breccias. In the inner breccia bodies, intense silicified rocks and massive and vuggy silica occur.

\subsubsection{Granitic plutons and granophyric stocks}

Massive, hololeucocratic to leucocratic, coarse-grained, inequigranular porphyritic hornblende-biotite monzogranite stocks and dikes crosscut the basement (Fig. 4), and partially intrude the Bom Jardim and Salustiano formations, but do not cut the upper volcanic rocks. These granitic rocks are coeval with caldera-related volcanism and are correlated with the lateorogenic Parauari magmatism, similar to the $\sim 1.88 \mathrm{Ga}$ Batalha and Rosa de Maio granites (Table 1; Santos et al., 2000; Juliani et al., submitted). These granitic rocks have granophyric textures, indicating shallow emplacement. Rhyolitic to rhyodacitic epizonal granophyric stocks related to hydrothermal systems crosscut the volcanics, tuffs, intracaldera sediments and the monzogranites. The granophyre may show strong fragmental features and a flow-oriented matrix, suggesting a genetic relationship with explosive hydrothermal breccias of ring volcanic cones. 


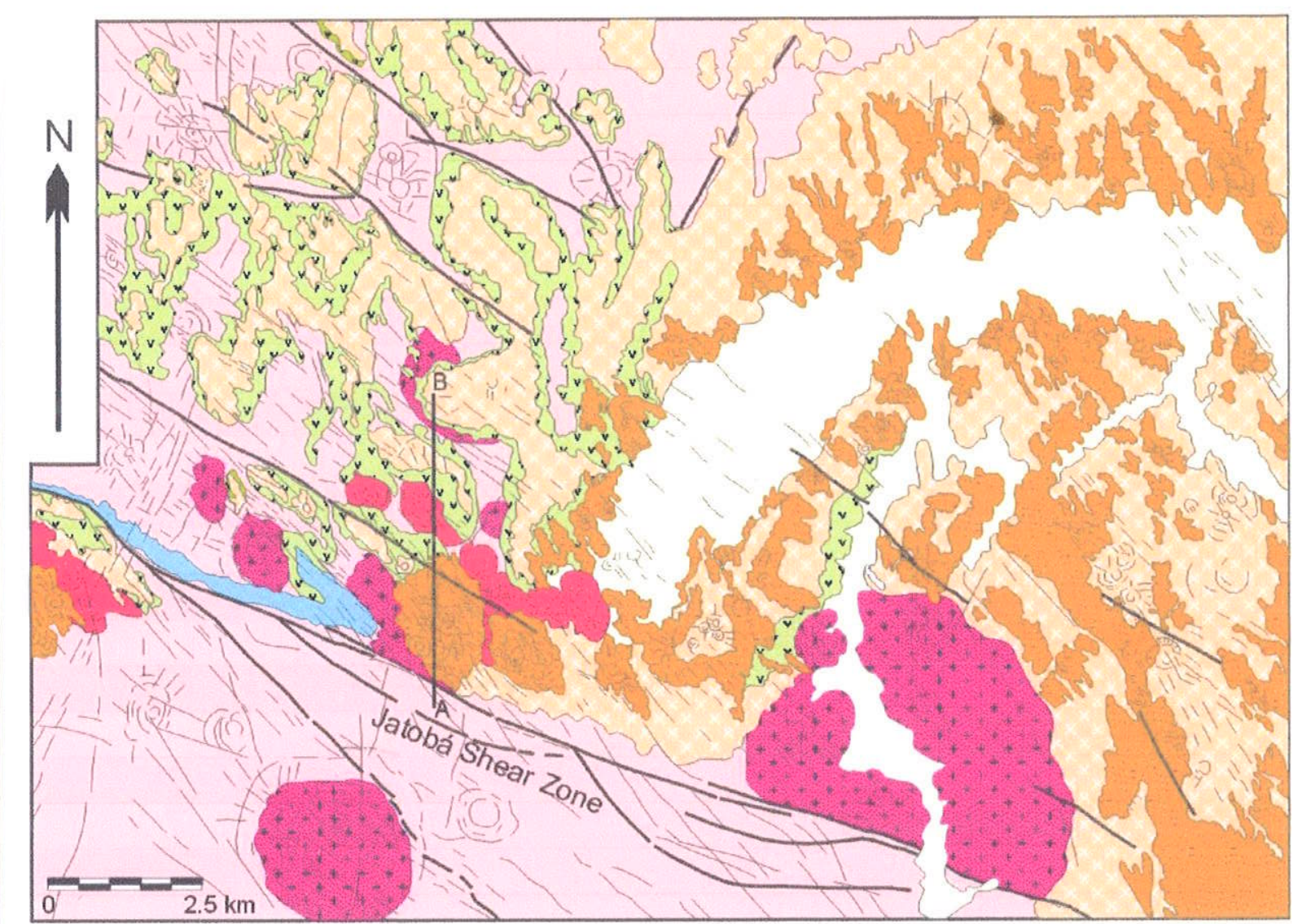

Post-caldera ring composite volcanoes and domes with hydrothermal explosive breccia bodies

Intracaldera deposits and Tertiary and Quartenary alluvial and colluvial deposits

Rhyolitic and rhyodacitic porphyry stocks

Caldera-related outflow deposit of Aruri and Salustiano Formations

Pre-caldera hyaloclastites

$\because$ Pre-caldera intermediate-composition volcanic rocks and tuffs of Bom Jardim Formation

$\therefore$ Late- to post-collisional Parauari granites

Basement, composed mainly of syn-collisional granodiorites of the Parauari Intrusive Suite

Faults

Ring and radial fractures associated with hydrothermal explosive breccia, stock, and granite intrusions or minor faults and fractured zones.

Fig. 4. Geologic map of the exploration area. $\tilde{A} B$ is line of cross section shown in Fig. 5. The arrow indicates the volcanic structure with high-sulfidation mineralization shown in Fig. 6.

\subsubsection{Late porphyry dikes}

Meter-thick dikes of fine-grained rhyodacitic porphyry crosscut all volcanic units. They are related to high-sulfidation mineralization in ring vents and have a dark red color mainly due to the potassic alteration that affects them. These hypabyssal intrusions probably are emplaced mainly along ring and radial structures of the calderas. 


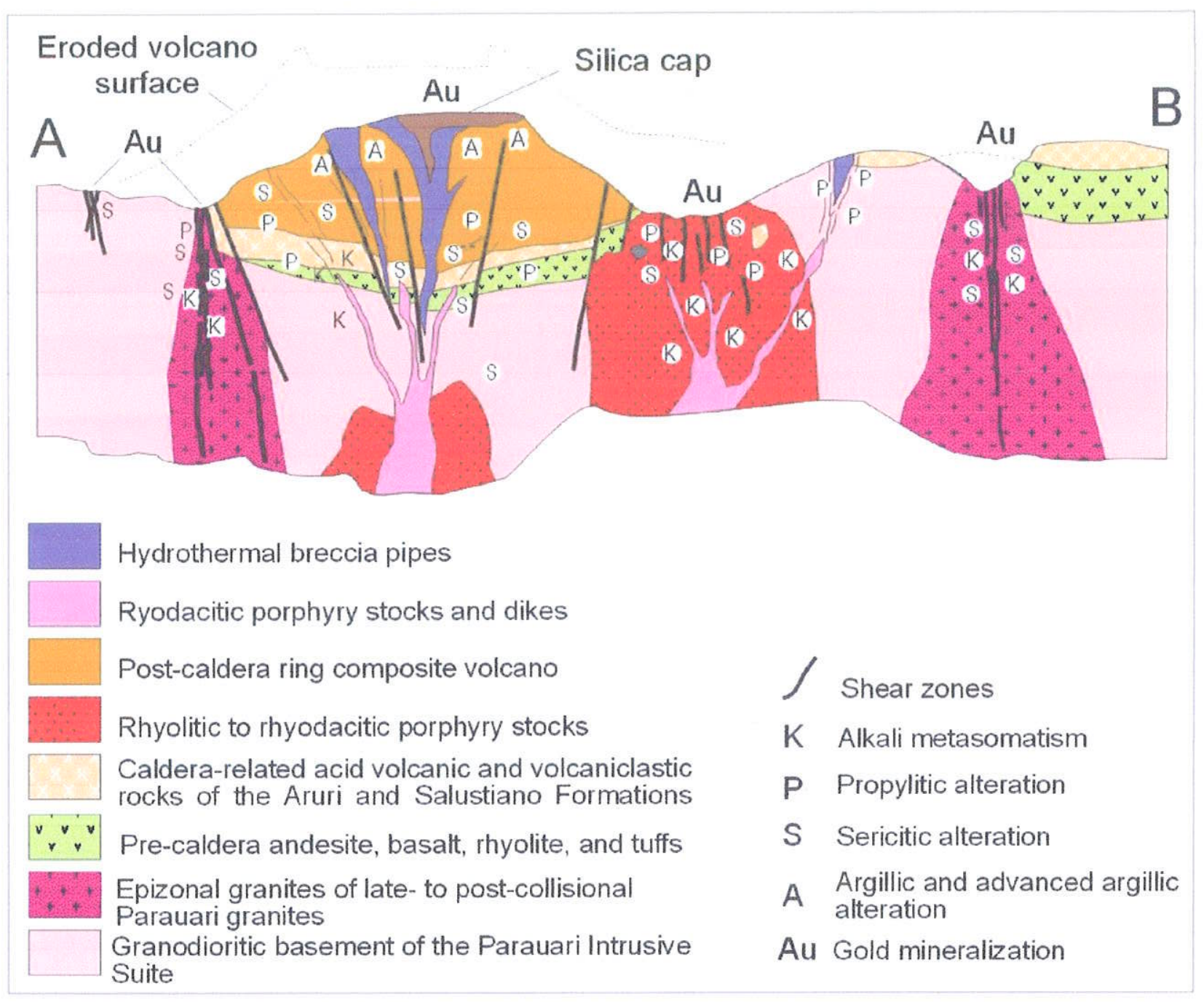

Fig. 5. Interpretative geologic cross section along ÃB in Fig. 4.

\subsection{Hydrothermal alteration}

A brecciated siliceous zone interpreted to be a silica cap was initially recognized from surface exposures of the hydrothermal breccias. Studies of samples from trenches and five holes (Fig. 6) drilled in and near the siliceous cap permitted three-dimensional reconstruction of the siliceous and related alteration as shown diagrammatically in Fig. 7.

\subsubsection{Silicification and hematitization}

The silica cap overlying the hydrothermal breccia on a ring volcano contains massive to layered bodies of siliceous rock, formed by acid leaching and silicification of breccias and ashflow tuffs. At depth, the inner alteration zones consist of massive and vuggy silica enclosed in a quartzalunite zone closely associated with the hydrothermal breccia at shallow levels of the volcanic structure. These siliceous rocks consist of microcrystalline quartz and contain hematite \pm pyrophyllite \pm alunite \pm sulfides and relict feldspar crystals. 


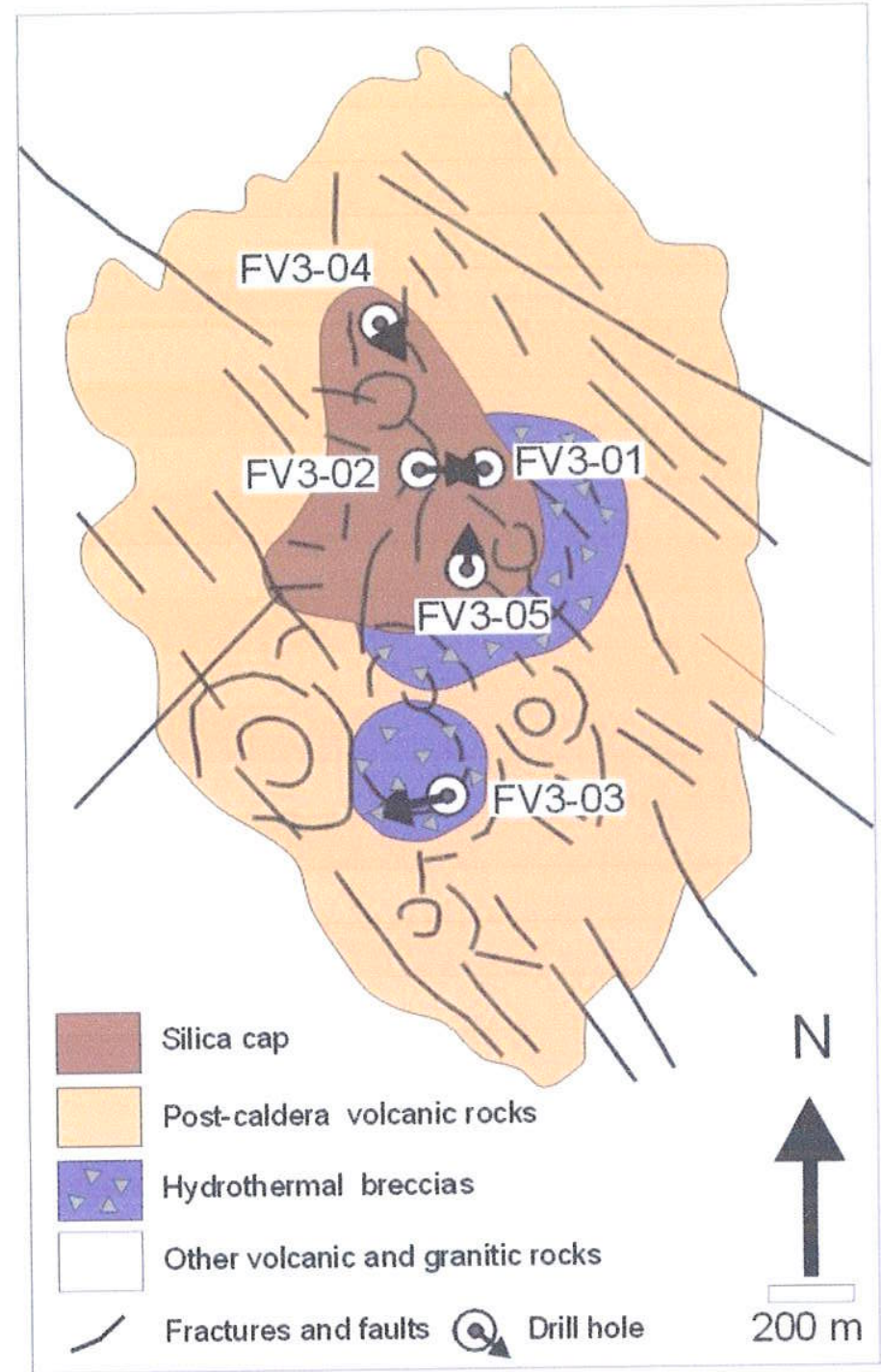

Fig. 6. Geologic map of one of the Tapajós high-sulfidation occurrences with location of drill holes.

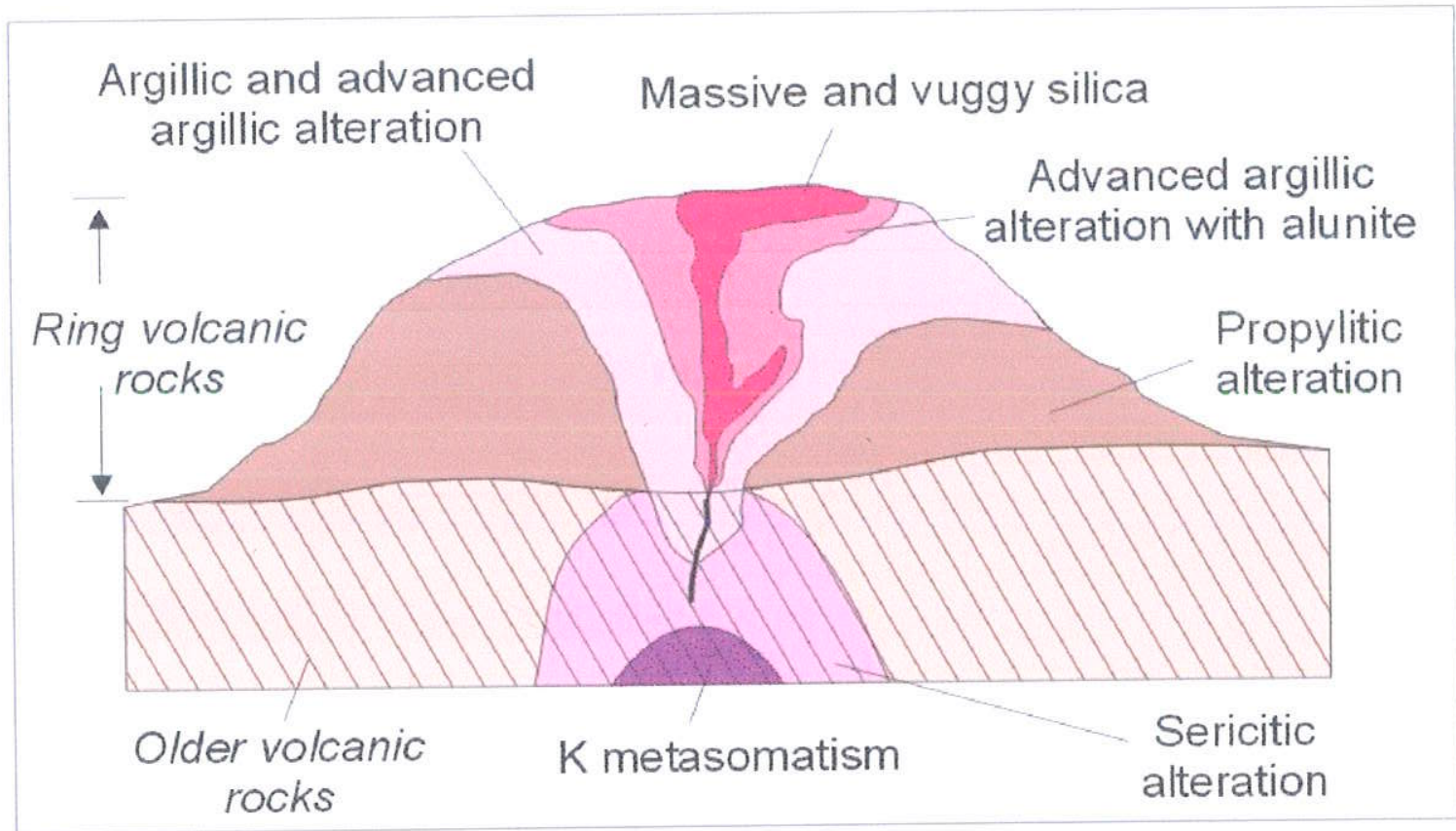

Fig. 7. Schematic reconstruction of alteration zones of a typical Tapajós high-sulfidation mineral occurrence in ring structure volcanic rocks based on studies of surface and drill hole samples. 
Hematite occurs only near the surface, replacing sulfides and infilling fractures. The silica cap is cut by silicified hydrothermal explosion breccias with fragments of tuff, silicified rhyolite, and red chalcedony as well as siliceous rock cemented by microcrystalline quartz and fine-grained hematite. Centimeter-thick irregular veins of milky quartz with subordinate pyrophyllite cut the silica cap.

\subsubsection{Advanced argillic alteration with quartz and alunite}

Quartz-alunite alteration has a strong correlation to hydrothermal breccia bodies, is concentrated mainly under the silica cap, and forms an envelope around the massive and vuggy silica. Close to the siliceous zones, welded tuff are strongly alunitized and cut by coarse-grained alunite veins. Alunite decreases progressively away from the hydrothermal breccias, as pyrophyllite increases, until alunite disappears approximately $200 \mathrm{~m}$ from the breccias. Also, the alunitized zones tend to disappear with depth, although alunite was identified down to $230 \mathrm{~m}$.

At the shallowest alunite levels, under the silica cap, five varieties of alunite are identified: $\left(A_{1}\right)$ red-colored, fine-grained, strongly foliated alunite, which completely replaces the preexisting rock (Fig. 8a); $\left(\mathrm{A}_{2}\right)$ foliated and folded veins of red coarse-grained alunite (Fig. $8 b) ;\left(A_{3}\right)$ red, fine-grained, foliated alunite, which crosscuts and replaces the $\left(A_{2}\right)$ alunite (Fig. $8 \mathrm{~b}) ;\left(\mathrm{A}_{4}\right)$ undeformed veins of rose-colored massive alunite with 2-cm long branching crystals (Fig. 8c); $\left(\mathrm{A}_{5}\right)$ rose-colored, fine-grained, randomly oriented alunite which crosscuts and replaces the $\left(\mathrm{A}_{4}\right)$ alunite branching crystals.

At depth, fine- to medium-grained alunite is typically associated with silicified hydrothermal breccia cement (Fig. 8d) and vuggy or massive silica zones containing disseminated sulfides (Fig. 8d). Three types of alunite were observed: $\left(B_{1}\right)$ medium- to finegrained, foliated alunite, associated with pyrite and woodhousenitesvambergite; $\left(\mathrm{B}_{2}\right)$ coarsegrained alunite associated with minor pyrite in non-foliated veins with diffuse contacts; $\left(\mathrm{B}_{3}\right)$ coarse-grained alunite that cut fissure filling to pervasive pyrite zones (Fig. 8f). All these types may be crosscut by kaolinite- and pyrophyllite-rich veins, sometimes containing andalusite, which is usually replaced by pyrophyllite or sericite, diaspore and kaolinite. Small enargitẽluzonite inclusions in pyrite were identified, as well as chalcopyrite, bornite, covellite, and small grains of native copper and silver, galena and sphalerite. Native gold occurs in the pyrophyllitic matrix and as fine inclusions in covellite. Gold contents in silica zones reach up to 4.5 ppm. Semi-quantitative EDS analyses of woodhouseitesvanbergite show $\mathrm{Sr}, \mathrm{Ca}, \mathrm{S}$ and P contents similar to those minerals described by Stoffregen and Alpers (1987) in the high sulfidation epithermal deposit of Summitville (USA) and Cu-porphyry of La Escondida (Chile). 

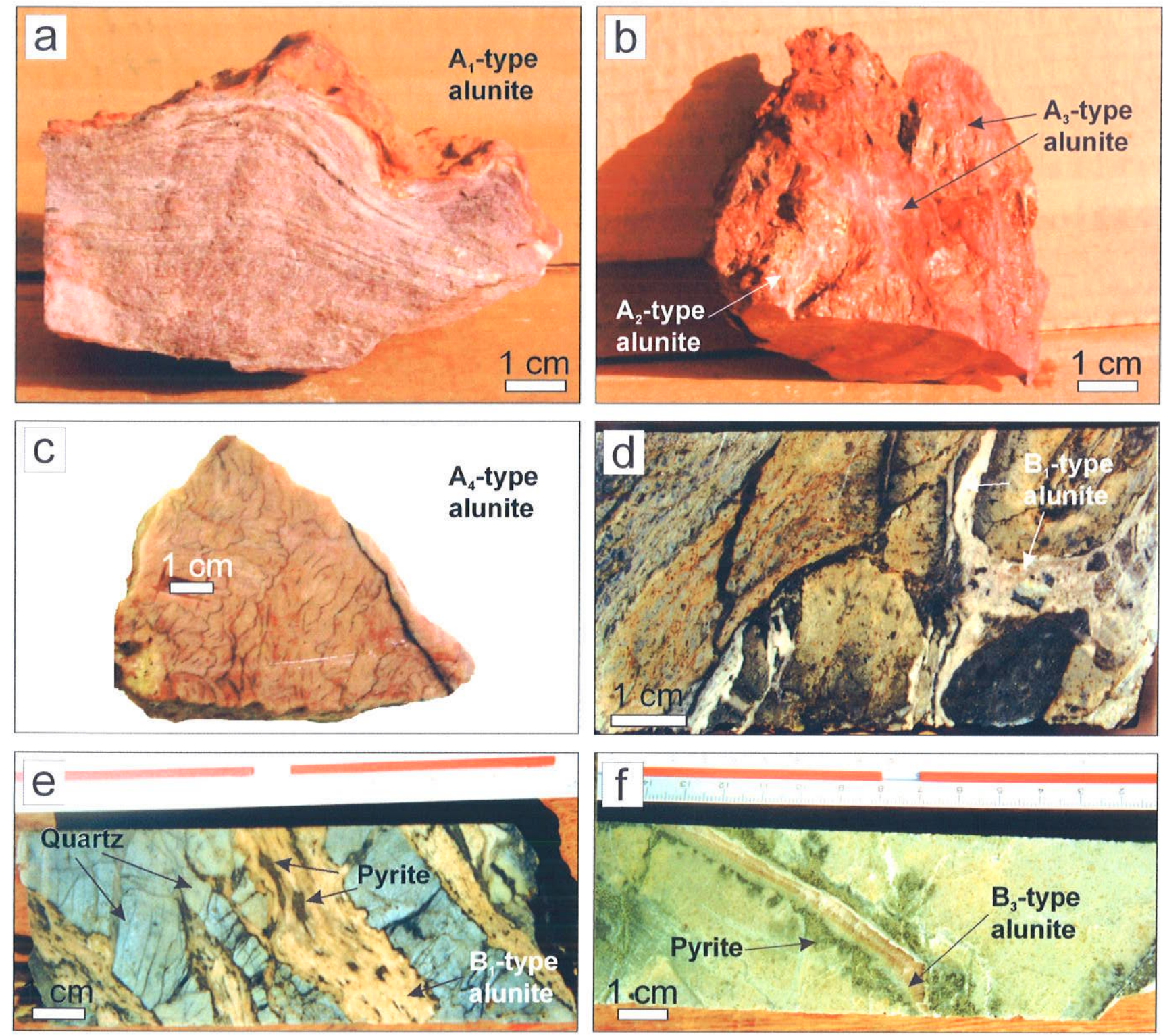

Fig. 8. Macroscopic features of the alunite types from shallow-deep zones: (a) $A_{1}$-type fine-grained, strongly foliated alunite (alunite schist); (b) $A_{2}$-type coarse-grained alunite replaced by $A_{3}$-type fine-grained foliated alunite; (c) $A_{+}$-type coarse-grained branching alunite from veins. Dark lines show crystal outline. Macroscopic features of the alunite types from deeper zones: (d) $B_{l}$-type fine-grained foliated alunite associated with pyrite cementing rounded fragments in hydrothermal breccia. The foliation follows the borders of the silicified rhyolitic fragments; (e) B-type fine-grained, foliated alunite associated with pyrite that envelopes microcrystalline quartz; $(f) B_{3}$-type coarse-grained alunite veins that replace fissure-controlled pyrite-rich zones. 


\subsubsection{Advanced argillic alteration}

Advanced argillic alteration is mainly observed in and around the hydrothermal breccia bodies. Within this alteration zone, incipient silicification with associated sulfides, was followed by brecciation, pyrophyllitization and late crystallization of kaolinite, illite and hematite near the surface.

The advanced argillic alteration occurs as either a pervasive or fissure filling mineral assemblage of pyrophyllite + quartz \pm pyrite \pm andalusite \pm diaspore \pm rutile. Woodhouseite-svanbergite, tourmaline, fluorite, and hematite are also present. The andalusite crystals are euhedral to anhedral, fractured, and partially pyrophyllitized and kaolinitized, with associated diaspore. The pyrophyllite + andalusite + quartz assemblage indicates temperatures greater than $330{ }^{\circ} \mathrm{C}$ for the advanced argillic alteration (Hemley et al., 1980). Decreasing temperature of hydrothermal fluids is indicated by the diaspore + pyrophyllite + kaolinite association, which locally replaces andalusite in the advanced argillic alteration. Locally, pyrophyllite is replaced by sericite.

In some parts of this alteration zone, prior silicification was not observed and the rock is composed of microcrystalline pyrophyllite with diaspore, rutile, hematite, in some places andalusite, and fine-grained crystals of corundum (?).

\subsubsection{Intermediate argillic alteration}

The intermediate argillic alteration occurs in outcrops close to an eroded body of hydrothermal breccias. In drill cores, it usually exists as thin or thick veins emplaced in the pyrophyllitized and alunitized rocks, or defining narrow zones within the sericitic alteration. The intermediate argillic alteration is characterized by the presence of kaolinite, sometimes dickite, sericite, chlorite, and feldspar remnants. In addition, this alteration type is observed as thin veins with sericite at the edges in rocks that underwent propylitic alteration, especially in the deeper levels of the hydrothermal breccias. These veins are more abundant in the deeper sericitic zone, increase in volume, and acquire a more pervasive style in proximity to the advanced argillic alteration zones.

\subsubsection{Sericitic alteration}

Weak fissure-controlled sericitic alteration is generally superimposed on the propylitic alteration. Pervasive sericitization is most conspicuous in the deeper outer alteration halo around the hydrothermal breccias and underlies the advanced argillic zone. Silicification zones are commonly linked to this alteration zone.

The most affected rocks are the ash-flow tuffs, showing strong replacement by sericite, with subordinate clay minerals. Rhyolitic ash-flow tuffs at the base of the ring volcanic structure 
were altered in selective pervasive style, with partial sericitization of the felsitic matrix, clasts, and feldspar phenocrysts, with associated fine-grained zeolites. Alunite-, pyrophyllite- and pyrite-bearing zones are present locally and pyrophyllitic or kaolinite veins are common within sericitic zones.

\subsubsection{Propylitic alteration}

Propylitization is observed in deeper parts of the ring volcano, especially in the dacitic rocks. Also it is present in the intermediate and acid rocks of the Bom Jardim and Salustiano formations, in areas farther from the ring volcanic centers, indicating that the external alteration halo is predominantly propylitic.

The propylitization style is generally pervasive but locally fissure filling, controlled by the igneous or volcaniclastic layering in deeper zones, or by volcanic brecciation. The typical paragenesis is represented by chlorite + epidote + carbonate + feldspar + sericite \pm quartz \pm pyrite.

The hydrothermal breccias beneath the advanced argillic alteration zones are propylitized, have a pyrite-rich matrix, and commonly show sericitization or pyrophyllitization in thin fissures. Toward the top of the volcanic vent there is an increase in volume and thickness of the micaceous veins and of small discontinuous veins with alunite + pyrite, which replace sulfides.

\subsubsection{Alkali metasomatism}

Alkali metasomatism was recognized in the granites, granophyres and porphyrys of the ring structure volcanic complexes (Fig. 4). This alteration is pervasive and similar to the one described by Corrêa-Silva et al. (2000) and Juliani et al. (submitted) in the Batalha goldmineralized granite in the Tapajós Gold Province. The early alteration is Na metasomatism, characterized by irregular and discontinuous albite crystallization on magmatic plagioclase and perthitic $\mathrm{K}$-feldspar rims. As $\mathrm{Na}$ metasomatism decreases, $\mathrm{K}$ metasomatism increases and is characterized by microcline, accompanied by green biotite, replacing magmatic biotite and amphibole. The hydrothermal microcline occupies intercrystal spaces and surrounds the igneous feldspars and quartz. It shows corrosion textures defined by concave inner contacts and irregular shredded rims. Microcline fills wedge-shaped spaces between minerals. Commonly irregular coalescent veins, not following the feldspar crystallographic orientation, almost completely replace plagioclase and orthoclase. The hydrothermal feldspars are cloudy under the microscope and macroscopically are reddish due to hematite microcrysts. Hydrothermal quartz is always 
present, as well as tourmaline and fluorite, both disseminated and in veins with carbonates. In the granitic rocks propylitic and sericitic alteration are younger than the $\mathrm{K}$ metasomatism.

\subsection{Chemical composition of alunite}

Representative microprobe analyses of alunite from deep- ( $B_{1}$-type) and shallow-level

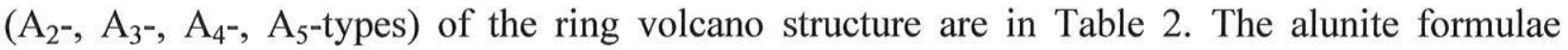
calculated according to Jambor (1999) ranges from $\left(\mathrm{K}_{0.95} \mathrm{Na}_{0.04}\right) \mathrm{Al}_{2.89}\left[\left(\mathrm{SO}_{4}\right)_{0.99}\left(\mathrm{PO}_{4}\right)_{0.01}\right]_{2}(\mathrm{OH})_{6}$ to $\left(\mathrm{Na}_{0.66} \mathrm{~K}_{0.35} \mathrm{Ca}_{0.01}\right)\left(\mathrm{Al}_{2.96} \mathrm{Fe}_{0.04}\right)\left[\left(\mathrm{SO}_{4}\right)_{0.99}\right]_{2}(\mathrm{OH})_{6} \quad$ Semi-quantitative EDS analyses of alunite indicate a lack of $\mathrm{Pb}, \mathrm{As}, \mathrm{Cu}$, and $\mathrm{Zn}$.

Deep-level, medium-grained ( $\mathrm{B}_{1}$-type) alunite crystals are high $\mathrm{Na}$, whereas fine-grained ( $B_{1}$-type) crystals are relatively enriched in $\mathrm{K}$ (Fig. 9a).

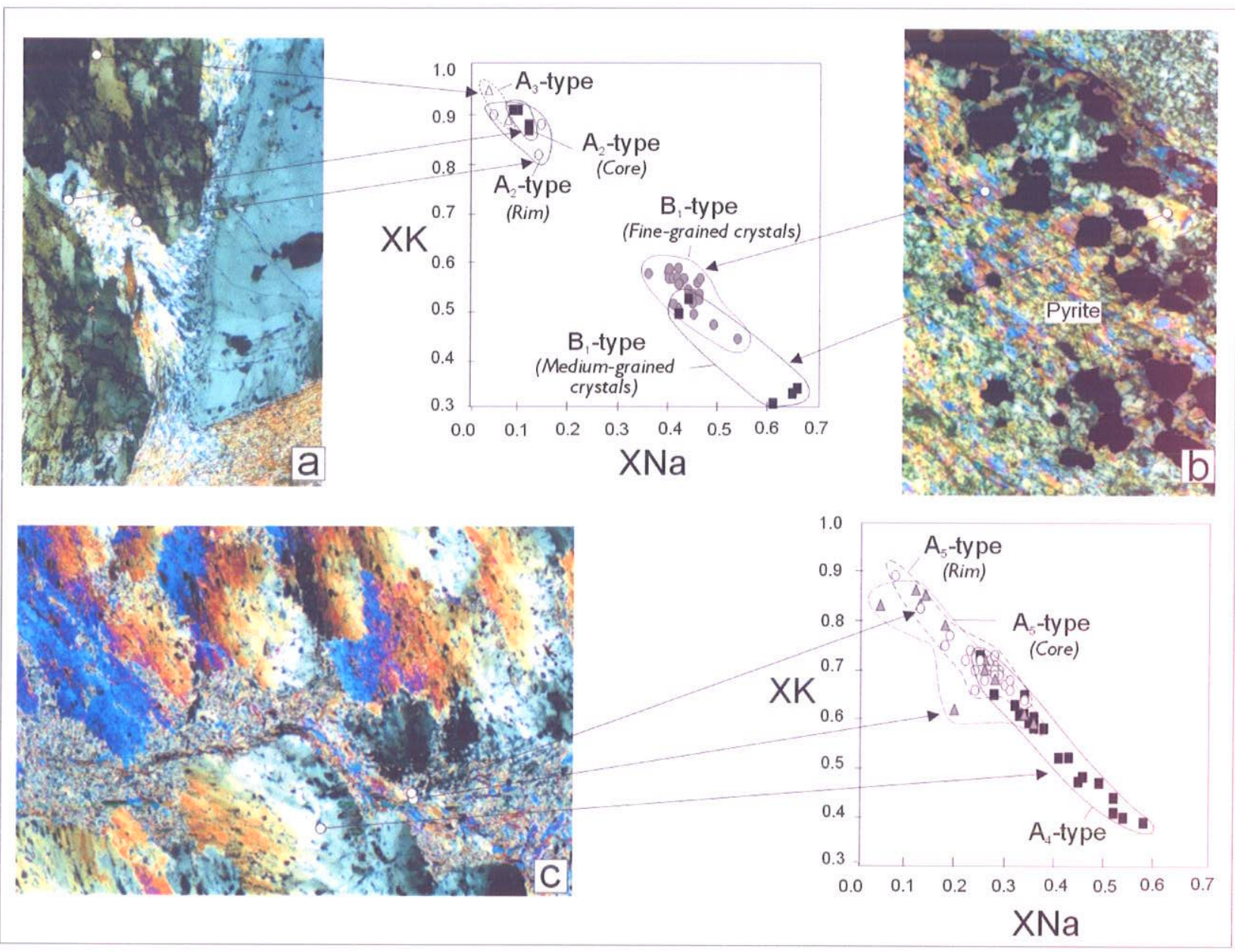

Fig. 9. Electron microprobe sodium and potassium molar fractions of different types of Tapajós alunite. (a) Coarse-grained alunite crystals (A2-type) with recrystallized rims partially replaced and enclosed by fine-grained foliated alunite (A3-type); (b) Fine- and medium-grained alunite from deep-level zones (B1type); (c) Coarse-grained alunite crystals (A 4-type) partially replaced by fine-grained alunite (A5-type). Transmitted light, crossed polarizes, larger photo side $=3.5 \mathrm{~mm}$. 
Table 2. Representative compositions of alunite.

\begin{tabular}{|c|c|c|c|c|c|c|c|c|c|c|c|c|c|c|c|}
\hline \multirow{3}{*}{$\begin{array}{l}\text { Sample } \\
\text { Type } \\
\text { Analyse }\end{array}$} & \multicolumn{4}{|c|}{$16 / 09$} & \multicolumn{7}{|c|}{$16 / 19$} & \multirow{2}{*}{\multicolumn{4}{|c|}{$\frac{01 / 16}{\text { IB }}$}} \\
\hline & \multicolumn{2}{|c|}{ IIA } & \multicolumn{2}{|c|}{ IIIA } & \multicolumn{2}{|c|}{ IVa } & \multicolumn{5}{|c|}{ VA } & & & & \\
\hline & 332 & 340 & 336 & 337 & 305 & 325 & 11 & 16 & 13 & 14 & 15 & 361 & 363 & 342 & 343 \\
\hline $\mathrm{K}_{2} \mathrm{O}$ & 9.92 & 9.69 & 10.02 & 10.48 & 4.43 & 4.62 & 6.56 & 6.53 & 7.82 & 8.00 & 7.73 & 3.74 & 4.05 & 6.68 & 5.94 \\
\hline $\mathrm{Na}_{2} \mathrm{O}$ & 0.71 & 0.90 & 0.59 & 0.31 & 4.33 & 3.93 & 2.68 & 2.77 & 2.12 & 1.97 & 1.94 & 4.63 & 4.96 & 2.98 & 3.25 \\
\hline $\mathrm{CaO}$ & 0.00 & 0.02 & 0.01 & 0.05 & 0.10 & 0.09 & 0.05 & 0.01 & 0.00 & 0.03 & 0.05 & 0.04 & 0.11 & 0.18 & 0.25 \\
\hline $\mathrm{Al}_{2} \mathrm{O} 3$ & 34.28 & 34.67 & 33.72 & 34.37 & 34.97 & 35.10 & 35.14 & 35.65 & 34.92 & 34.59 & 34.61 & 36.67 & 36.59 & 35.73 & 36.14 \\
\hline $\mathrm{Fe}_{2} \mathrm{O}_{3}$ & 0.04 & 0.00 & 0.13 & 0.00 & 0.00 & 0.00 & 0.00 & 0.04 & 0.00 & 0.10 & 0.00 & 0.03 & 0.31 & 0.02 & 0.30 \\
\hline $\mathrm{SO}_{3}$ & 36.84 & 37.07 & 38.01 & 37.02 & 38.43 & 38.61 & 38.32 & 37.83 & 38.02 & 37.86 & 36.45 & 39.35 & 38.69 & 37.85 & 37.55 \\
\hline $\mathrm{BaO}$ & 0.00 & 0.48 & 0.15 & 0.15 & 0.80 & 0.23 & 0.12 & 0.00 & 0.00 & 0.19 & 0.34 & 0.00 & 0.07 & 0.00 & 0.07 \\
\hline $\mathrm{P}_{2} \mathrm{O}_{5}$ & 0.18 & 0.31 & 0.15 & 0.25 & 0.09 & 0.06 & 0.00 & 0.10 & 0.14 & 0.21 & 0.17 & 0.06 & 0.06 & 0.27 & 0.49 \\
\hline $\mathrm{SiO}_{2}$ & 0.01 & 0.02 & 0.01 & 0.04 & 0.02 & 0.03 & 0.00 & 0.01 & 0.01 & 0.03 & 0.00 & 0.03 & 0.03 & 0.09 & 0.01 \\
\hline Total & 81.98 & 83.15 & 82.79 & 82.65 & 83.16 & 82.67 & 82.86 & 82.93 & 83.02 & 82.98 & 81.29 & 84.56 & 84.85 & 83.80 & 84.00 \\
\hline $\mathrm{K}$ & 0.91 & 0.88 & 0.89 & 0.95 & 0.39 & 0.41 & 0.58 & 0.58 & 0.70 & 0.71 & 0.72 & 0.32 & 0.35 & 0.59 & 0.53 \\
\hline $\mathrm{Na}$ & 0.10 & 0.12 & 0.08 & 0.04 & 0.58 & 0.52 & 0.36 & 0.38 & 0.29 & 0.27 & 0.27 & 0.61 & 0.66 & 0.40 & 0.44 \\
\hline $\mathrm{Ca}$ & 0.00 & 0.00 & 0.00 & 0.00 & 0.01 & 0.01 & 0.00 & 0.00 & 0.00 & 0.00 & 0.00 & 0.00 & 0.01 & 0.01 & 0.02 \\
\hline $\mathrm{Ba}$ & 0.00 & 0.01 & 0.00 & 0.00 & 0.02 & 0.01 & 0.00 & 0.00 & 0.00 & 0.01 & 0.01 & 0.00 & 0.00 & 0.00 & 0.00 \\
\hline $\mathrm{Al}$ & 2.91 & 2.91 & 2.77 & 2.89 & 2.85 & 2.85 & 2.88 & 2.95 & 2.87 & 2.85 & 2.97 & 2.92 & 2.96 & 2.93 & 2.98 \\
\hline $\mathrm{Fe}$ & 0.01 & 0.00 & 0.02 & 0.00 & 0.00 & 0.00 & 0.00 & 0.00 & 0.00 & 0.01 & 0.00 & 0.00 & 0.04 & 0.00 & 0.04 \\
\hline S & 1.99 & 1.98 & 1.99 & 1.98 & 1.99 & 1.99 & 2.00 & 1.99 & 1.99 & 1.99 & 1.99 & 1.99 & 1.99 & 1.98 & 1.97 \\
\hline P & 0.01 & 0.02 & 0.01 & 0.01 & 0.01 & 0.00 & 0.00 & 0.01 & 0.01 & 0.01 & 0.01 & 0.00 & 0.00 & 0.02 & 0.03 \\
\hline $\mathrm{Si}$ & 0.00 & 0.00 & 0.00 & 0.00 & 0.00 & 0.00 & 0.00 & 0.00 & 0.00 & 0.00 & 0.00 & 0.00 & 0.00 & 0.01 & 0.00 \\
\hline Total & 5.92 & 5.93 & 5.77 & 5.90 & 5.85 & 5.79 & 5.83 & 5.92 & 5.86 & 5.85 & 5.97 & 5.86 & 6.02 & 5.94 & 6.01 \\
\hline
\end{tabular}


Coarse-grained crystals ( $\mathrm{A}_{2}$-type) of alunite below the silica cap are relatively $\mathrm{K}$-enriched and replaced by oriented fine-grained alunite $\left(\mathrm{A}_{3}\right.$-type), which is slightly more potassic (Fig. 9a). The undeformed branching crystals $\left(\mathrm{A}_{4}\right.$-type) show the largest variation of $\mathrm{X}_{\mathrm{Na}}$ content $(0.25$ to $0.60)$ and $X_{K}$ content $(0.37$ to 0.75$)$. They are replaced by more potassic fine- to medium-grained alunite $\left(\mathrm{A}_{5}\right.$-type), which has the highest $\mathrm{K}$ contents at the rims of crystals (Fig. 9b).

The relationship between alunite composition, hydrothermal fluid evolution and deformational events is not understood, but the data set indicates that the fine-grained alunite, which replaces the coarse alunite from different generations, is characteristically more potassic. The $\mathrm{K}$ rich alunite in veins $\left(\mathrm{A}_{2^{-}}, \mathrm{A}_{3^{-}}\right.$and $\mathrm{A}_{5}$-type $)$ occur only at shallow levels, while Na-rich alunite richer in $\mathrm{Na}$ ( $\mathrm{B}_{1}$-type) occurs predominantly in deeper zones. Branching veins of relatively sodic alunite $\left(\mathrm{A}_{4}\right.$-type) occur also under the silica cap. This could indicate temperature decreasing (Stoffregen and Cygan, 1990; Stoffregen et al., 2000) from the bottom to the top, related to the fluid evolution. Undeformed Na-rich alunite veins, under the silica cap, could be associated with later relatively high-temperature fluid pulses. It appears that the events leading to the deformation of alunite did not affect its chemical composition and that the original compositional history reflecting the environment of primary fluids is preserved.

\subsection{ArrAr dating of alunite}

The argon data are presented in Table 3 with detailed analytical procedures given in the footnotes of Table 3. A summary of ${ }^{40} \mathrm{Ar} /{ }^{39} \mathrm{Ar}$ age-spectrum results for alunites from the Tapajós gold occurrence showing interpretation in terms of geologic processes is shown in Table 4 . These ages are also shown with stable isotope data in Table 5. Fig. 10 is a composite age spectrum diagram including eight of nine alunite spectra analyzed from the Tapajós gold prospect. Seven of these spectra yield plateaus or high-temperature maximum ages that fall between $1846 \pm \_2$ (plateau age for sample FV3-1/16) and $1869 \pm 2$ Ma (high-temperature age for sample X1-16/18) and show variable amounts of apparent ${ }^{40} \mathrm{Ar}$ loss in the lower temperature steps. Detailed discussion of argon retention for these samples is given in a companion paper (Landis et al., this volume). As discussed in that paper the cluster of ages is interpreted to represent formation of the magmatic hydrothermal alunite in the high-sulfidation deposit at $1869 \mathrm{Ma}$. The younger apparent ages ranging down to $1846 \mathrm{Ma}$ are interpreted to reflect varying degrees of partial resetting after formation of the alunites which resulted from prolonged thermal activity in the region after $1869 \mathrm{Ma}$. We do not exclude the possibility that multiple periods of alunite formation may have occurred but it is unlikely that a high-sulfidation mineralization existed for the entire 20 m.y. period. 
TABLE 3. ${ }^{40} \mathrm{Ar} /{ }^{39} \mathrm{Ar}$ DATA FOR ALUNITES* FROM HIGH-SULFIDATION MINERALIZATION

IN THE TAPAJOS GOLD PROVINCE, BRASIL

\begin{tabular}{|c|c|c|c|c|c|c|c|c|c|}
\hline $\begin{array}{r}\text { Temp } \\
\left({ }^{\circ} \mathrm{C}\right)\end{array}$ & ${ }^{40} \mathrm{Ar}_{\mathrm{R}}$ & ${ }^{39} \mathrm{Ar}_{\mathbf{K}}$ & ${ }^{38} \mathbf{A r}_{\mathrm{Cl}}$ & ${ }^{38} \mathrm{Ar}_{\mathrm{Cl}}{ }^{36} \mathrm{Ar}_{\mathrm{At}}$ & ${ }^{39} \mathbf{A r}_{\mathbf{K}} /{ }^{36} \mathbf{A r}_{\mathrm{At}}$ & $\% \operatorname{Rad}$ & $\%{ }^{39} \mathrm{Ar}_{\mathrm{K}}$ & \multicolumn{2}{|c|}{$\begin{array}{c}\text { Age+Error } \\
\text { (Ma) }\end{array}$} \\
\hline \multicolumn{10}{|c|}{ X1-16/18, Alunite, $1^{\text {st }}$ generation, coarse-grained } \\
\hline 550 & 4.2549 & 0.08103 & 0.00045 & 2.5 & 450 & 98.8 & 4.8 & 1750 & \pm 2 \\
\hline 600 & .47634 & .0093 & .00010 & 2.5 & 231 & 97.3 & .5 & 1728 & \pm 9 \\
\hline 650 & 15.145 & .27174 & .00055 & 5.0 & 2470 & 99.8 & 16.1 & 1818 & \pm 2 \\
\hline 675 & 24.572 & .43128 & .00125 & 5.7 & 1960 & 99.7 & 25.6 & 1843 & \pm 2 \\
\hline 725 & 47.602 & .82307 & .00320 & 15.2 & 3922 & 99.9 & 48.8 & 1861 & \pm 2 \\
\hline 775 & 3.8563 & .06620 & .00046 & 4.2 & 602 & 99.1 & 3.9 & 1869 & \pm 2 \\
\hline 850 & .1285 & .0023 & .00007 & .78 & 26 & 82.7 & .1 & 1816 & \pm 61 \\
\hline 1300 & .0124 & .0009 & .00007 & .44 & 5.4 & 21.0 & .1 & 673 & \pm 24 \\
\hline
\end{tabular}

X1-16/G, Alunite, $1^{\text {st }}$ generation, coarse-grained

Total-gas date: $1848 \pm 2$ Ma; No plateau; Weighted-mean date $=1851 \pm 2 ; \mathrm{J}=0.031368,0.1 \%$; wt $10.3 \mathrm{mg}$

$\begin{array}{cccccccccc}600 & 0.0429 & 0.0023 & 0.00037 & 2.47 & 15.5 & 0.3 & 0.1 & 822 & \pm 46 \\ 700 & 55.375 & .97529 & .00120 & 1.46 & 1189 & 2.1 & 33.1 & 1845 & \pm 2 \\ 800 \mathrm{w} & 19.291 & .33867 & .00084 & 5.60 & 2258 & 4.3 & 11.5 & 1849 \pm 2 \\ 850 \mathrm{w} & 26.824 & .47098 & .00110 & 7.86 & 3364 & 3.7 & 16.0 & 1849 \pm 2 \\ 900 \mathrm{w} & 11.533 & .20219 & .00090 & 30.0 & 6740 & 4.0 & 6.9 & 1850 \pm 2 \\ 950 \mathrm{w} & 46.561 & .81387 & .00331 & 66.2 & 16277 & 6.9 & 27.6 & 1854 & \pm 2 \\ 1000 \mathrm{w} & 7.2928 & .12750 & .00146 & 48.7 & 4250 & 24.1 & 4.3 & 1854 & \pm 2 \\ 1025 & .6850 & .0134 & .00025 & 6.25 & 334 & 12.1 & .5 & 1728 & \pm 17 \\ 1050 & .1504 & .0030 & .00006 & 0.86 & 4.23 & 3.1 & .1 & 1721 & \pm 23 \\ 1075 & .0150 & .0014 & .00003 & 1.50 & 71.5 & 2.9 & .0 & 514 & \pm 6\end{array}$

X1-16/F, Alunite, $2^{\text {nd }}$ generation, coarse-grained

Total-gas date: $1835 \pm 4$ Ma; Plateau date $=1853 \pm 3 ; \mathrm{J}=0.007257,0.12 \%$; wt.11.3 mg

\begin{tabular}{|c|c|c|c|c|c|c|c|c|c|}
\hline $250 \mathrm{~b}$ & 0.0091 & 0.0017 & 0.0013 & 0.45 & 0.56 & 1.0 & 0.2 & 70 & \pm 8 \\
\hline 300 & .0503 & .0008 & .0001 & .16 & 1.20 & 21.1 & .1 & 703 & \pm 32 \\
\hline 400 & .0016 & .00006 & .00001 & .03 & .17 & 1.5 & .0 & 301 & \pm 56 \\
\hline 450 & .0012 & .00008 & .00001 & .03 & .22 & 1.1 & .0 & 197 & \pm 30 \\
\hline 450 & .0180 & .0004 & .00002 & .05 & .81 & 12.4 & .0 & 572 & \pm 11 \\
\hline 500 & .0628 & .0006 & .00006 & .15 & 1.56 & 35.2 & .1 & 1011 & \pm 59 \\
\hline 550 & .3015 & .0018 & .00005 & .13 & 4.66 & 72.9 & .2 & 1449 & \pm 12 \\
\hline 550 & 1.1762 & .0059 & .00005 & .12 & 13.72 & 90.3 & .6 & 1615 & \pm 14 \\
\hline 575 & 3.7452 & .0167 & .00007 & .18 & 43.95 & 97.1 & 1.8 & 1743 & \pm 5 \\
\hline 600 & 21.728 & .09414 & .00043 & .52 & 115 & 98.9 & 10.4 & 1775 & \pm 7 \\
\hline 625 & 1.5509 & .00679 & .00008 & .17 & 14.45 & 91.8 & .7 & 1763 & \pm 2 \\
\hline $650^{\mathrm{P}}$ & 48.764 & .19753 & .00127 & 1.2 & 186 & 99.4 & 21.7 & 1852 & \pm 2 \\
\hline $675^{P}$ & 71.107 & .28732 & .00095 & .86 & 261 & 99.5 & 31.6 & 1855 & \pm 4 \\
\hline $725^{\mathrm{P}}$ & 71.918 & .29140 & .00143 & .75 & 153 & 99.2 & 32.0 & 1852 & \pm 2 \\
\hline 800 & .7200 & .0031 & .00005 & .04 & 2.67 & 67.9 & .3 & 1794 & \pm 14 \\
\hline 950 & .0217 & .0006 & .00003 & .03 & .63 & 7.8 & .1 & 451 & \pm 5 \\
\hline 1200 & .0030 & .0007 & .00007 & .11 & 1.20 & 1.7 & .1 & 53 & \pm 9 \\
\hline
\end{tabular}


FV3-1/16, Alunite, $1^{\text {st }}$ generation, fine-grained; $\mathbf{1}^{\text {st }}$ analysis

Total-gas date: $1820 \pm 11 \mathrm{Ma}$; Plateau date $=1834 \pm 3 ; \mathrm{J}=0.007257,0.12 \%$; wt. $8.3 \mathrm{mg}$

\begin{tabular}{|c|c|c|c|c|c|c|c|c|c|}
\hline $250 \mathrm{~b}$ & -0.0005 & 0.00061 & 0.00067 & 0.32 & 0.29 & -0.1 & 0.2 & -12 & \pm 80 \\
\hline 450 & .0051 & .0001 & .00004 & 0.57 & 1.86 & 19.9 & .0 & 472 & +79 \\
\hline 525 & .0358 & .0002 & .00001 & .17 & 4.0 & 66.1 & .1 & 1374 & \pm 31 \\
\hline 600 & 2.9703 & .0154 & .00003 & .38 & 195 & 99.2 & 5.0 & 1623 & \pm 9 \\
\hline $675^{\mathrm{P}}$ & 48.016 & .20660 & .00000 & nd & 413 & 99.7 & 67.9 & 1827 & \\
\hline $700^{\mathrm{P}}$ & 16.450 & .0694 & .00016 & 2.29 & 992 & 99.9 & 22.8 & 1850 & \pm 15 \\
\hline 725 & 2.1660 & .0091 & .00000 & nd & 101 & 98.8 & 3.0 & 1853 & \pm 26 \\
\hline 750 & .2368 & .0010 & .00002 & 1.0 & 52 & 97.7 & .3 & 1804 & \pm 21 \\
\hline 800 & .3434 & .0017 & .00000 & nd & 16.8 & 91.9 & .6 & 1682 & \pm 11 \\
\hline 950 & .0118 & .0004 & .00003 & .60 & 7.2 & 42.2 & .1 & 398 & \pm 81 \\
\hline 1150 & .0250 & .0003 & .00002 & .33 & 5.5 & 57.7 & .1 & 818 & \pm 96 \\
\hline 1350 & .0419 & .0002 & .00001 & .01 & 0.19 & 13.5 & .1 & 1883 & \pm 30 \\
\hline
\end{tabular}

FV3-1/16, Alunite, 1st generation, fine-grained; 2nd analysis

Total-gas date: $1808 \pm 2 \mathrm{Ma}$; Plateau date $=1846 \pm 2 ; \mathrm{J}=0.031319,0.1 \% ;$ wt. $10.4 \mathrm{mg}$

\begin{tabular}{|c|c|c|c|c|c|c|c|c|}
\hline 500 & 11.063 & .23061 & .00084 & 1.68 & 461 & 98.7 & 14.3 & 1655 \\
\hline 550 & 9.8095 & .18067 & .00024 & 3.00 & 2258 & 99.8 & 11.2 & 1792 \\
\hline 575 & 10.154 & .18280 & .00035 & 8.75 & 4570 & 99.9 & 11.3 & 1818 \\
\hline $600^{\mathrm{P}}$ & 53.307 & .93741 & .00143 & 4.90 & 3232 & 99.8 & 58.0 & 1845 \\
\hline 625 & 3.6651 & .06420 & .00033 & 2.54 & 494 & 99.0 & 4.0 & 1850 \\
\hline 650 & .5555 & .0102 & .00015 & 5.00 & 340 & 98.5 & .6 & 1796 \\
\hline 675 & .1151 & .0021 & .00004 & 4.00 & 212 & 96.5 & .1 & 1794 \\
\hline 700 & .1297 & .0025 & .00006 & 6.00 & 252 & 96.9 & .2 & 1734 \\
\hline 750 & .1248 & .0028 & .00008 & 1.60 & 56 & 89.2 & .2 & 1580 \\
\hline 1000 & .0146 & .0034 & .00010 & 1.67 & 57 & 46.9 & .2 & 227 \\
\hline
\end{tabular}

FV3-1/11, Alunite, 1st generation, fine-grained cement

Total-gas date: $1842+2 \mathrm{Ma}$; Weighted-mean date $=1867+2 ; \mathrm{J}=0.029713,0.1 \%$; wt. $11.6 \mathrm{mg}$

$\begin{array}{cccccccccc}250 \mathrm{~b} & 0.0632 & 0.0056 & 0.00358 & 0.71 & 1.10 & 4.1 & 0.1 & 523 & \pm 13 \\ 400 & .0346 & .0018 & .00008 & .12 & 2.72 & 14.6 & .0 & 798 & \pm 31 \\ 500 & .36830 & .0093 & .00007 & .14 & 19.3 & 72.2 & .2 & 1408 & \pm 3 \\ 550 & 6.0797 & .1549 & .00179 & 1.90 & 165 & 95.6 & 3.4 & 1395 & \pm 12 \\ 575 & 29.146 & .50582 & .00163 & 2.91 & 903 & 99.4 & 11.0 & 1800 & \pm 2 \\ 600 & 4.0921 & .06904 & .00020 & .30 & 103 & 95.4 & 1.5 & 1832 & \pm 2 \\ 625 \mathrm{w} & 141.73 & 2.3243 & .00824 & 6.87 & 1937 & 99.7 & 50.5 & 1865 & \pm 2 \\ 650 \mathrm{w} & 2.8361 & .04676 & .00018 & .11 & 28.1 & 85.2 & 1.0 & 1859 \pm 2 \\ 675 \mathrm{w} & 88.623 & 1.4466 & .00537 & 3.03 & 817 & 99.4 & 31.4 & 1871 & \pm 2 \\ 700 \mathrm{w} & 1.9878 & .0326 & .00024 & .67 & 90.7 & 94.9 & .7 & 1863 & \pm 4 \\ 725 & .1046 & .0021 & .00003 & .06 & 3.96 & 40.0 & .0 & 1638 \pm 23 \\ 800 & .0041 & .0003 & .00005 & .07 & 2.52 & 1.9 & .0 & 643 & \pm 43 \\ 1200 & .0019 & .0007 & .00005 & .07 & .92 & .9 & .0 & 143 & \pm 23\end{array}$


FV3-2/7, Alunite, $2^{\text {nd }}$ generation, coarse-grained

Total-gas date: $1828 \pm 2 \mathrm{Ma}$; No plateau; $\mathrm{T} \max =1857 \pm 2 ; \mathrm{J}=\mathbf{0 . 0 3 1 3 0 0 , 0 . 1 \%}$; wt. $11.7 \mathrm{mg}$

$\begin{array}{cccccccccc}500 & 0.1026 & 0.0023 & 0.00032 & 2.13 & 15.3 & 69.4 & 0.1 & 1579 & \pm 29 \\ 550 & 13.234 & .25955 & .00063 & 3.32 & 1366 & 99.6 & 11.1 & 1721 & \pm 3 \\ 600 & 62.696 & 1.11194 & .00020 & 20 & 111000 & 99.9 & 47.4 & 1835 & \pm 2 \\ 650 & 48.138 & .84323 & .00118 & 5.90 & 4216 & 99.9 & 35.9 & 1849 & \pm 2 \\ 675 & 3.5697 & .0623 & .00014 & 2.80 & 1246 & 99.6 & 2.7 & 1853 & \pm 5 \\ 700 & 3.436 & .05975 & .00013 & 1.62 & 747 & 99.3 & 2.5 & 1857 & \pm 2 \\ 800 & .4113 & .0077 & .00005 & .71 & 110 & 95.0 & .3 & 1771 & \pm 10 \\ 1250 & .0290 & .0013 & .00008 & 4.00 & 67.0 & 84.2 & .1 & 932 & \pm 91\end{array}$

FV3-1/25, Alunite, $2^{\text {nd }}$ generation, coarse-grained

Total-gas date: $1842 \pm 2 \mathrm{Ma}$; Plateau date $=1858 \pm 2 ; \mathrm{J}=0.031310,0.1 \%$; w. $9.9 \mathrm{mg}$

$\begin{array}{cccccccccc}500 & 0.0437 & 0.0011 & 0.00035 & 3.89 & 5.95 & 43.4 & 0.0 & 1434 & \pm 33 \\ 550 & 1.5847 & .03564 & .00027 & 3.86 & 509 & 98.6 & 1.5 & 1574 & \pm 3 \\ 575 & 35.587 & .63959 & .00040 & 2.22 & 3553 & 99.8 & 27.3 & 1820 & \pm 2 \\ 600 & 10.867 & .19055 & .00005 & .83 & 3176 & 99.8 & 8.1 & 1848 & \pm 2 \\ 625 & .2147 & .0038 & .00004 & 2.00 & 190 & 97.7 & .2 & 1838 & \pm 16 \\ 650^{\mathrm{P}} & 17.616 & .30732 & .00048 & 9.60 & 6146 & 99.9 & 13.1 & 1854 & \pm 3 \\ 675 & \mathrm{P} & 64.373 & 1.1186 & .00237 & 39.5 & 18643 & 99.9 & 47.4 & 1859 \\ 700 & 2.456 & .04256 & .00014 & 2.80 & 851 & 99.4 & 1.8 & 1862 & \pm 4 \\ 750 & .2786 & .0051 & .00007 & .64 & 46.3 & 89.6 & .2 & 1800 & \pm 13 \\ 1000 & .0745 & .0020 & .00009 & 1.00 & 22.2 & 74.5 & .1 & 1394 & \pm 16\end{array}$

FV3-1/12, Alunite, $3^{\text {rd }}$ generation, fine-grained; sheared

Total-gas date: $1712 \pm 2 \mathrm{Ma}$; No plateau; $\mathrm{T} \max =1805 \pm 2 ; \mathrm{J}=0.030540,0.1 \%$; wt. $9.6 \mathrm{mg}$

$\begin{array}{cccccccccc}450 & 0.0196 & 0.0009 & 0.00006 & 0.38 & 5.44 & 29.8 & 0.0 & 948 & \pm 15 \\ 525 & .0334 & .0014 & .00005 & .62 & 17.5 & 57.5 & .1 & 984 & \pm 46 \\ 550 & 1.2173 & .04009 & .00006 & 1.50 & 1002 & 98.9 & 1.9 & 1184 & \pm 1 \\ 600 & 32.469 & .67332 & .00027 & 3.86 & 9619 & 99.9 & 32.7 & 1633 & \pm 2 \\ 625 & 66.445 & 1.2228 & .00046 & 1.92 & 5095 & 99.9 & 59.4 & 1765 & \pm 2 \\ 650 & 4.0219 & .07140 & .00003 & .43 & 1020 & 99.5 & 3.5 & 1805 & \pm 2 \\ 675 & 2.1886 & .03902 & .00008 & 1.60 & 780 & 99.3 & 1.9 & 1800 \pm 2 \\ 800 & .3920 & .0074 & .00009 & .82 & 67.8 & 92.3 & .4 & 1728 \pm 7 \\ 1200 & .0160 & .0036 & .00013 & 1.44 & 39.7 & 36.6 & .2 & 231 & \pm 9\end{array}$

FV3-3/3, Alunite, 1st generation, fine-grained

Total-gas date: $99.4 \pm 0.4 \mathrm{Ma}$; Weighted-mean date $=51.3 \pm 0.1 ; \mathrm{J}=0.031170,0.1 \%$; wt. $11.9 \mathrm{mg}$

$\begin{array}{cccccccccc}400 & 0.0023 & 0.0005 & 0.00014 & 2.0 & 7.0 & 10.4 & 0.0 & 244 & \pm 62 \\ 450 & .0334 & .0059 & .00029 & 1.4 & 28 & 34.5 & .2 & 293 & \pm 15 \\ 500 & .0505 & .0182 & .00014 & 2.8 & 363 & 77.0 & .7 & 150 & \pm 12 \\ 525 & .10659 & .08247 & .00006 & 1.0 & 1374 & 84.3 & 3.0 & 71 & \pm 2 \\ 550 & .46165 & .47654 & \text { bd } & \text { bd } & 5295 & 93.8 & 17.5 & 53.7 & \pm 0.1 \\ 575 \mathrm{w} & .50682 & .54896 & \text { bd } & \text { bd } & 13724 & 96.9 & 20.1 & 51.2 & \pm 0.1 \\ 600 \mathrm{w} & .66374 & .71565 & \text { bd } & \text { bd } & 23855 & 97.6 & 26.2 & 51.4 & \pm 0.1 \\ 625 & 1.0437 & .82427 & \text { bd } & \text { bd } & 9159 & 96.8 & 30.2 & 69.8 & \pm 0.3 \\ 650 & .0992 & .0073 & .00004 & 1.0 & 183 & 89.9 & .3 & 636 & \pm 3 \\ 700 & .3797 & .0110 & .00010 & 3.3 & 366 & 97.4 & .4 & 1320 & \pm 7 \\ 1000 & 1.6138 & .03995 & .00033 & 1.9 & 235 & 92.3 & 1.5 & 1470 \pm 2\end{array}$


"Ninety-nine percent pure alunite was picked from vein material collected from 3 surface samples (X numbers) and from 6 drill core samples (FV numbers). Each alunite was gently ground to 250-125 micrometers. Minor pyrite $(<1 \%)$ was not removed. The alunite samples were cleaned with reagent-grade acetone, alcohol, and deionized water and air-dried. Eight to 12 mg of each alunite were wrapped in an aluminum foil packages. Two aliquants of one alunite sample, FV3-1/16, were irradiated in two different irradiation packages and analyzed twice. Seven of the ten samples were encapsulated in silica glass vials with other samples and fluence standards adjacent to each unknown. Three of the ten samples were each encapsulated alone in "break-seal" silica glass vials and evacuated to better than $10^{-8}$ torr; for these three samples, the neutron-fluence standards were enclosed in adjacent silica vials. One of the two aliquants of sample FV3-1/16 was irradiated in a "breakseal" vial; the other was irradiated the other way. The standard for this experiment is hornblende MMhb-1 with percent $\mathrm{K}=1.555$, ${ }^{40} \mathrm{Ar}_{\mathrm{R}}=$ $1.624 \times 10^{-9} \mathrm{~mole} / \mathrm{gm}$ (Samson and Alexander, 1987), and K-Ar age $=523.1 \pm 2.6 \mathrm{Ma}$ (age reevaluated by Renne et al. 1998). For irradiation, an aluminum canister was loaded with the silica vials. The samples were irradiated in three different irradiation packages. The first irradiation package contained FV3-1/16 in a "breakseal" vial and it was irradiated for 30 hours in the TRIGA reactor at the U.S. Geological Survey in Denver, Colorado. Because of the promising results of this experiment, eight additional alunite samples were irradiated for 129 hours in a second package; the longer irradiation period was employed to acquire more optimal ${ }^{40} \mathrm{Ar}_{\mathrm{R}} /{ }^{39} \mathrm{Ar}_{\mathrm{K}}$ ratios. This second irradiation package also contained a "breakseal" vial. A third irradiation for 30 hours contained one alunite sample in a "breakseal" vial. The alunites and standards were analyzed in the Denver Argon Laboratory of the U.S. Geological Survey using a Mass Analyser Products 215 rare-gas mass spectrometer on a Faraday-cup collector. The vacuum-encapsulated vials were loaded into the extraction system and baked at $250^{\circ} \mathrm{C}$ before the vacuum seal was broken on line and the released gas was analyzed to determine whether any argon had been recoiled from the sample during irradiation. These analyzed fractions are indicated as the $250 \mathrm{~b}$ step on the above table. All alunite samples were heated in a double-vacuum low-blank resistance furnace for 20 minutes, in a series of 8 to 17 steps, to a maximum of $1350^{\circ} \mathrm{C}$, and analyzed using the standard stepwise heating technique described by Snee (in press). Each standard was degassed to release argon in a single step at $1250^{\circ} \mathrm{C}$. For every argon measurement, five isotopes of argon ( ${ }^{40} \mathrm{Ar}$, ${ }^{39} \mathrm{Ar},{ }^{38} \mathrm{Ar},{ }^{37} \mathrm{Ar}$, and ${ }^{36} \mathrm{Ar}$ ) are measured. Detection limit at the time of this experiment was $2 \times 10^{-17}$ moles of argon.

${ }^{+}$Abundance of ${ }^{40} \mathrm{Ar}_{\mathrm{R}}$ (Radiogenic $\left.{ }^{40} \mathrm{Ar}\right),{ }^{39} \mathrm{Ar}_{\mathrm{K}}\left(\mathrm{K}\right.$-derived ${ }^{39} \mathrm{Ar}$ ), and ${ }^{38} \mathrm{Ar}_{\mathrm{Cl}}\left(\mathrm{Cl}\right.$-derived $\left.{ }^{38} \mathrm{Ar}\right)$ is measured in volts and calculated to five decimal places. Voltage may be converted to moles using $1.160 \times 10^{-12}$ moles argon per volt signal. The "F" value can be directly calculated from the data on the table. All isotopic abundances have been corrected for mass discrimination. Mass discrimination was determined by calculating the ${ }^{40} \mathrm{Ar} /{ }^{36} \mathrm{Ar}$ ratio of aliquants of atmospheric argon pipetted from a fixed pipette on the extraction line; the ratio during this experiment was 298.9, which was corrected to 295.5 to account for mass discrimination. Final isotopic abundances were corrected for all interfering isotopes of argon including atmospheric argon. ${ }^{37} \mathrm{Ar}$ and ${ }^{39} \mathrm{Ar}$, which are produced during irradiation, are radioactive and their abundances were corrected for radioactive decay. Abundances of interfering isotopes from $\mathrm{K}$ and Ca were calculated from reactor production ratios determined by irradiating and analyzing pure $\mathrm{CaF}_{2}$ and $\mathrm{K}_{2} \mathrm{SO}_{4}$; the $\mathrm{K}_{2} \mathrm{SO}_{4}$ was degassed in a vacuum furnace prior to irradiation to release extraneous argon. Corrections for $\mathrm{Cl}$-derived ${ }^{36} \mathrm{Ar}$ were determined using the method of Roddick (1983). Production ratios for this experiment are available in Snee (in press).

(a) Apparent ages and associated errors were calculated from analytical data then rounded using associated analytical errors. Apparent ages of each fraction include the error in $\mathrm{J}$ value $(0.1 \%)$, which was calculated from the reproducibility of splits of the argon from several standards. Apparent ages were calculated using decay constants of Steiger and Jager (1977). All apparent age errors are cited at 1 sigma. Uncertainties in the calculations for apparent age of individual fractions were calculated using equations of Dalrymple et al. (1981).

${ }^{\mathrm{P}}$ Fraction included in plateau date. Plateaus determined according to the method of Fleck et al. (1977).

${ }^{\mathrm{w}}$ Fraction included in weighted-mean date.

Also shown on Fig. 10 is the age spectrum for sample FV3-1/12. This alunite has a texture which indicates it was clearly deformed by younger structural activity. Its age spectrum exhibits an increase in apparent ages with increasing release temperature, a pattern characteristic of apparent ${ }^{40} \mathrm{Ar}$ loss. This mixing of younger argon in the lower temperature steps with older argon in higher temperature steps is interpreted to be a result of later structural and thermal activity of unknown age.

Figs. 11 and 12 are the age spectrum and isochron diagrams for FV3-3/3 alunite. The age spectrum has the classic U-shaped character attributable to incorporation of excess ${ }^{40} \mathrm{Ar}$. Despite the presence of this excess argon, more than 46-percent of the ${ }^{39} \mathrm{Ar}$ released in two temperature steps defines an apparent age of $51.3 \pm 0.1 \mathrm{Ma}$, interpreted to represent the maximum estimate for the age of formation. The isochron diagram confirms this apparent age and shows that a second component of radiogenic argon with a Proterozoic signature is present in the sample.

We interpret this older argon reservoir to be incorporated from argon released from older country rocks during the processes that formed this supergene alunite. 


\section{Alunites - Tapajós Gold Province}

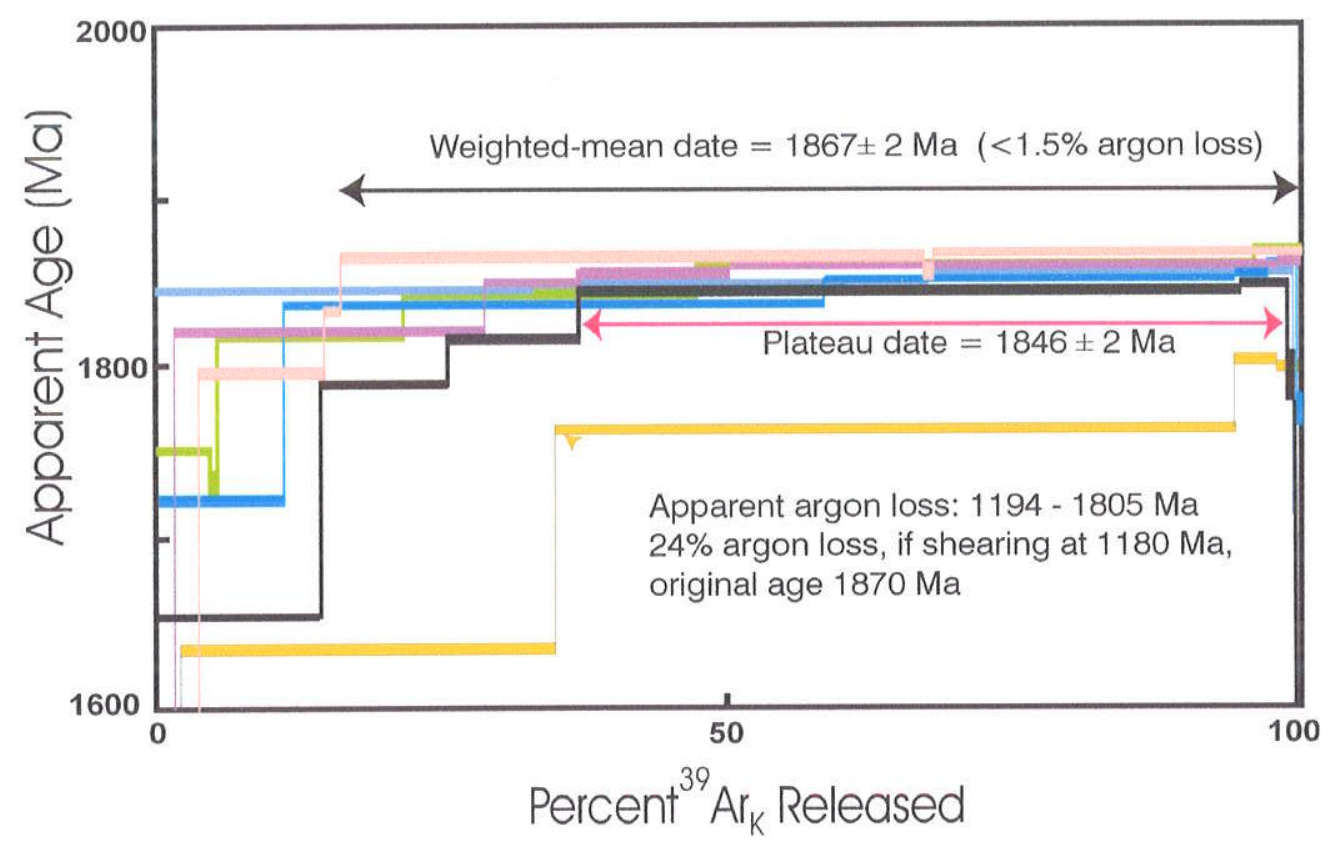

Fig. 10 Composite ${ }^{40} \mathrm{Ar}{ }^{\beta^{9}} \mathrm{Ar}$ age-spectrum diagram showing age spectra of 8 alunite samples from the Tapajos Gold Province. Plateaus or high-temperature release ages for seven of these spectra lie between $1869 \pm 2$ and $1846 \pm 2 \mathrm{Ma}$. Interpreted age of high-sulfidation system is $1869 \mathrm{Ma}$; younger ages reflect extended cooling or partial resetting of argon systematics between 1869 and $1846 \mathrm{Ma}$. Apparent argon loss in lower temperature release steps may be due to younger structural or thermal activity. Age spectrum showing apparent argon loss from 1194 to 1805 Ma is for a deformed alunite and reflects younger structural and thermal activity that locally affected the deposit. Details of interpretation are discussed in Landis et al (this volume).

Supergene Alunite - Tapajós Gold Province

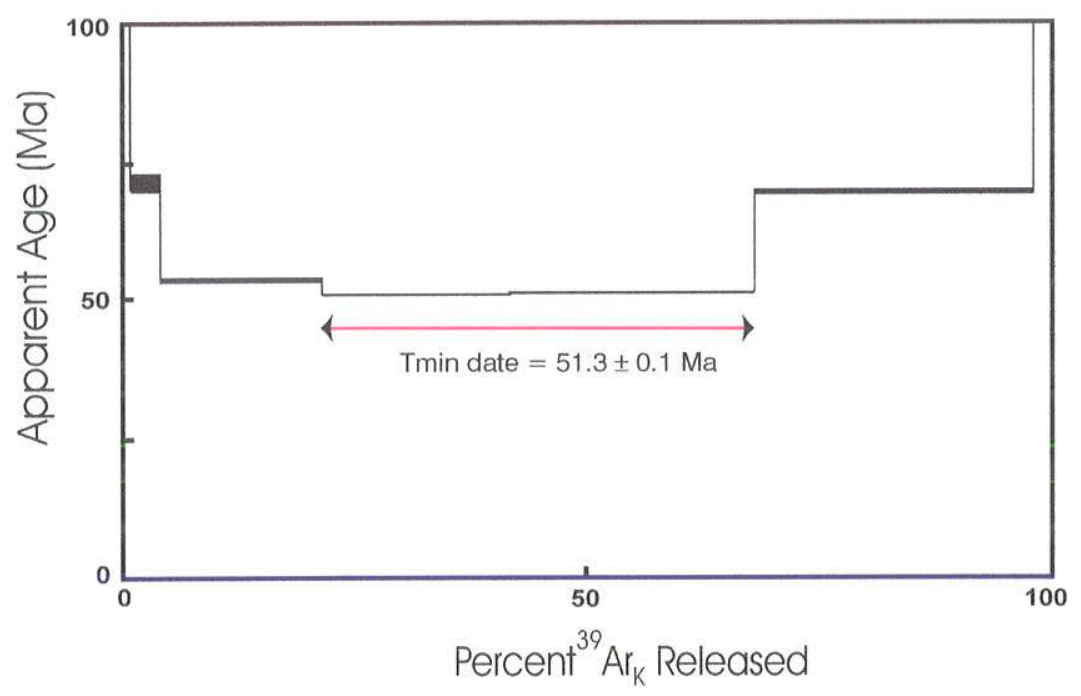

Fig. $11{ }^{40}$ Ar ${ }^{39}$ Ar age-spectrum diagram for supergene alunite sample FV3-3/3 from the Tapajos Gold Province. U-shaped spectrum is typical for a sample containing excess ${ }^{40} A r$. Despite presence of excess argon, apparent age of two temperature steps comprising 46.3-percent of total released ${ }^{39} \mathrm{Ar}$ is $51.3 \pm 0.1$ Ma and is interpreted to be the maximum age for supergene alunite formation. 
Supergene Alunite - Tapajós Gold Province

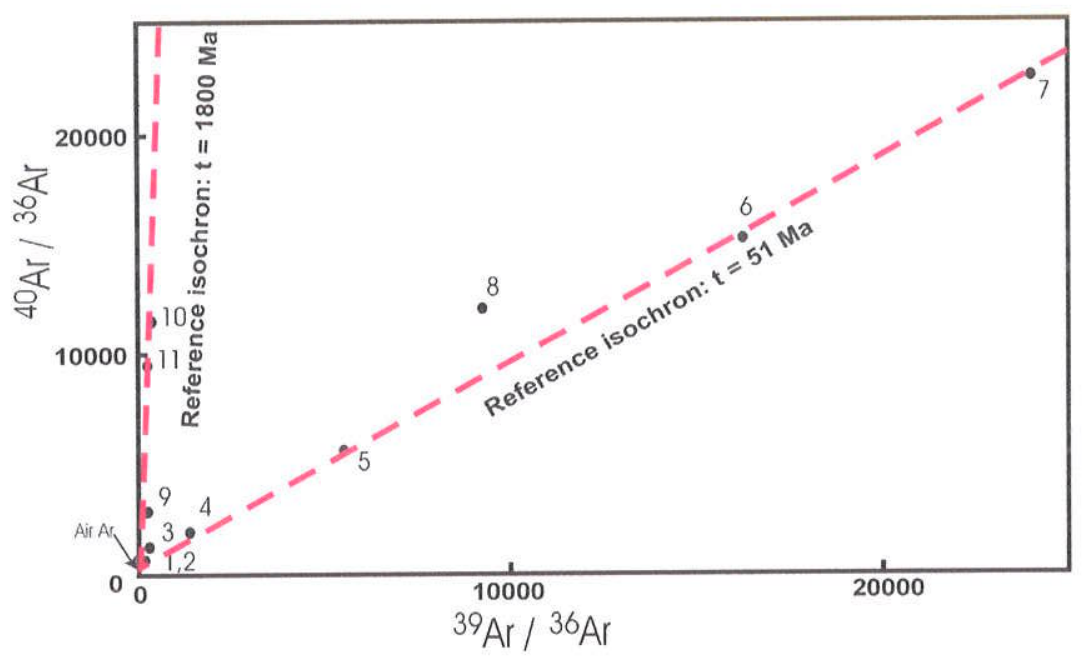

Fig. $12{ }^{40} \mathrm{Ar}{ }^{36} \mathrm{Ar} v \mathrm{~s}^{39} \mathrm{Ar}{ }^{36} \mathrm{Ar}$ isochron diagram for supergene alunite sample. Data for eleven temperature steps are bracketed by two reference isochrones with ages of 51 and $1800 \mathrm{Ma}$. Distribution of data indicate two reservoirs of radiogenic argon with apparent ages of approximately 51 and Proterozoic ages. Isochron analysis supports the interpretation that the formation age of supergene alunite is $\leq 51 \mathrm{Ma}$ and minor excess argon released from host rocks during weathering process was incorporated.

Table 4. Summary of ${ }^{40} \mathrm{Ar} /{ }^{39} \mathrm{Ar}$ Age-Spectrum Results for Alunites from High-Sulfidation Mineralization, Tapajós Gold Province, Brasil

\begin{tabular}{|c|c|c|c|c|}
\hline SAMPLE \# & EVENT & $\begin{array}{l}\text { Apparent } \\
\text { Age } \\
\text { (Ma) }\end{array}$ & Type of Age & Comment \\
\hline FV3-1/11* & MINERALIZATION & $1867 \pm 2$ & $\begin{array}{c}\text { Weighted } \\
\text { mean }\end{array}$ & $\begin{array}{l}\text { Near plateau defined by } 83.6 \% \text { of } \\
\text { released }{ }^{39} \mathrm{Ar} ; \text { Tmax }=1871 \mathrm{Ma}\end{array}$ \\
\hline$X 1-16 / 18$ & MINERALIZATION & $1869 \pm 2$ & Maximum & $\begin{array}{l}\text { Apparent argon loss with age rising } \\
\text { from } 1750 \text { to } 1869 \mathrm{Ma}\end{array}$ \\
\hline FV3-1/25 & 个 & $1858 \pm 2$ & Plateau & $\begin{array}{l}\text { Plateau defined by } 62.3 \% \text { of released } \\
{ }^{39} \mathrm{Ar} \text {; apparent argon loss, age rises to } \\
\qquad 1862 \pm 4\end{array}$ \\
\hline FV3-2/7 & Cooling & $1857 \pm 2$ & Maximum & $\begin{array}{l}\text { Apparent argon loss with age rising } \\
\text { from } 1721 \text { to } 1857 \mathrm{Ma}\end{array}$ \\
\hline $\mathrm{X} 1-16 / \mathrm{F}^{*}$ & and/or & $1853 \pm 3$ & Plateau & $\begin{array}{l}\text { Plateau defined by } 85.3 \% \text { of released } \\
{ }_{39} \mathrm{Ar}\end{array}$ \\
\hline $\mathrm{X} 1-16 / \mathrm{G}$ & Thermal & $1851 \pm 2$ & $\begin{array}{l}\text { Weighted } \\
\text { mean }\end{array}$ & $\begin{array}{l}\text { Near plateau defined by } 43 \% \text { of } \\
\text { released }{ }^{39} \mathrm{Ar} \text {; } \operatorname{Tmax}=1854 \mathrm{Ma}\end{array}$ \\
\hline $\begin{array}{l}\text { FV3-1/16 } \\
\text { (2) }\end{array}$ & Resetting & $1846 \pm 2$ & Plateau & $\begin{array}{l}\text { Plateau defined by } 62 \% \text { of released } \\
\text { 39 Ar; apparent argon loss, age rises to } \\
1850 \mathrm{Ma}\end{array}$ \\
\hline $\begin{array}{l}\text { FV3-1/16* } \\
\text { (1) }\end{array}$ & & $1834 \pm 17$ & Plateau & $\begin{array}{c}\text { Plateau defined by } 93.7 \% \text { of released } \\
{ }^{39} \mathrm{Ar} \text {; large error due to low }{ }^{39} \mathrm{Ar} \\
\text { abundance; apparent argon loss, age } \\
\text { rises to } 1853 \mathrm{Ma}\end{array}$ \\
\hline FV3-1/12 & Shearing & $1805 \pm 2$ & Maximum & $\begin{array}{l}\text { Apparent argon loss with age rising } \\
\text { from } 1184 \text { to } 1805 \mathrm{Ma}\end{array}$ \\
\hline FV3-3/3 & $\begin{array}{c}\text { Supergene/ } \\
\text { Climatic effects }\end{array}$ & $51.3 \pm 0.1$ & $\begin{array}{l}\text { Weighted } \\
\text { mean }\end{array}$ & $\begin{array}{c}\text { Excess argon; near plateau in saddle } \\
\text { defined by } 46.3 \% \text { of released }{ }^{39} \mathrm{Ar} \\
\text { isochron reflects mixing of three or } \\
\text { more argon reservoirs }\end{array}$ \\
\hline
\end{tabular}

$\mathrm{X}$ in sample number refers to surface sample; FV in sample number refers to core sample; * - breakseal encapsulated 


\subsection{Stable Isotopic data}

The stable isotope data are typical of classical magmatic hydrothermal alunite observed in studies of many deposits including Summitville, Julcani, Rodalquilar, Lepanto, Pierina and Tombo as summarized by Rye et al. (1992), Arribas Jr. (1995), Hedenquist et al. (1998), Deyell et al. (this volume) and Fifarek et al. (this volume). These alunites form from sulfuric acid created during the disproportionation of $\mathrm{SO}_{2}$ during the condensation of a magmatic vapor plume that arises from the brittleductile transition beginning at about $400{ }^{\circ} \mathrm{C}$ (Rye, 1993; Fournier, 1999).

Figure 13 summarizes the temperature data (Table 5) based on sulfur isotope fractionations in coexisting alunite and pyrite from the surface and drill holes using the experimental data of Ohmoto and Lasaga (1982). The surface sample is from the silica cap. Its pyrite has been oxidized so its $\delta^{34} \mathrm{~S}$ value is assumed to have been 1 permil. The temperatures range from 420 to $130{ }^{\circ} \mathrm{C}$ with the highest temperatures in the deepest sample and the lowest from surface in the silica cap. Previous studies (summarized in Rye, 1993; Rye, this volume) have shown that the alunitepyrite sulfur isotope fractionations are an excellent geothermometer for magmatic hydrothermal alteration. The sulfur isotope temperatures (Table 5; Fig. 13) are consistent with magmatic hydrothermal alteration in other high sulfidation systems. In addition, three of the four $\mathrm{SO}_{4} \mathrm{OH}$ oxygen isotope temperatures in Table 4 are in excellent agreement with the sulfur isotope temperatures. The sulfur and oxygen isotope temperature data almost certainly represent primary alteration temperatures that have not been affected by metamorphism. The high temperatures for some of the deep samples are consistent with the occurrence of andalusite in the alteration assemblages (Hemley et al., 1980).

In Table 5 the $\delta^{34} \mathrm{~S}$ values of alunite range from 4.1 to 38.2 permil and values for coexisting pyrite range from -6.6 to 1.7 permil. All except two $\delta{ }^{34} \mathrm{~S}$ alunite values are greater than 14.3 permil. The exceptions are: 1) a sample with a $\delta^{34} \mathrm{~S}$ value of 4.1 permil from the shallow depths (FV3̃3/3; Table 5); this has recently shown an argon age of about $51 \mathrm{Ma}$ and is obviously supergene; 2) a recrystallized sample with a value of 12.4 permil also from a shallow depth in a drill hole (FV3̃1/12; Table 5). If the $\mathrm{H}_{2} \mathrm{~S} \mathrm{SO}_{4}$ and $\delta^{34} \mathrm{~S}_{\Sigma \mathrm{S}}$ of the system are constant both can be estimated using a simple level rule for the data on Fig. 13. For the data set as a whole, most of the change in isotope composition is in the alunite suggesting that for the entire system $\mathrm{H}_{2} \mathrm{~S} / \mathrm{SO}_{4}>1$ as is typical of magmatic hydrothermal high-sulfidation systems (Rye, 1993, Arribas Jr., 1995). However, for drill hole samples most of the change in sulfur isotope composition is in the pyrite suggesting that the $\mathrm{H}_{2} \mathrm{~S}_{/} \mathrm{SO}_{4}$ was probably not constant for all alunite deposition. 
The surface samples collected from the silica cap show two generations of alunite where coarse-grained, isotopically heavy alunite with a sulfur isotope temperature of about $140{ }^{\circ} \mathrm{C}$ is cut by fine-grained isotopically light alunite with a temperature of $270{ }^{\circ} \mathrm{C}$. Both of these occurrences are magmatic hydrothermal alunite suggesting major pulsing in the vertical extent of the magmatic vapor plume that gave rise to the alteration. The large $\delta^{34} \mathrm{~S}$ values for the alunite require that the sulfuric acid for the acid sulfate alteration was derived from the disproportionation of $\mathrm{SO}_{2}$ in a magmatic vapor plume that equilibrated with wall rocks.

\section{Alunite-pyrite sulfur isotope temperatures}

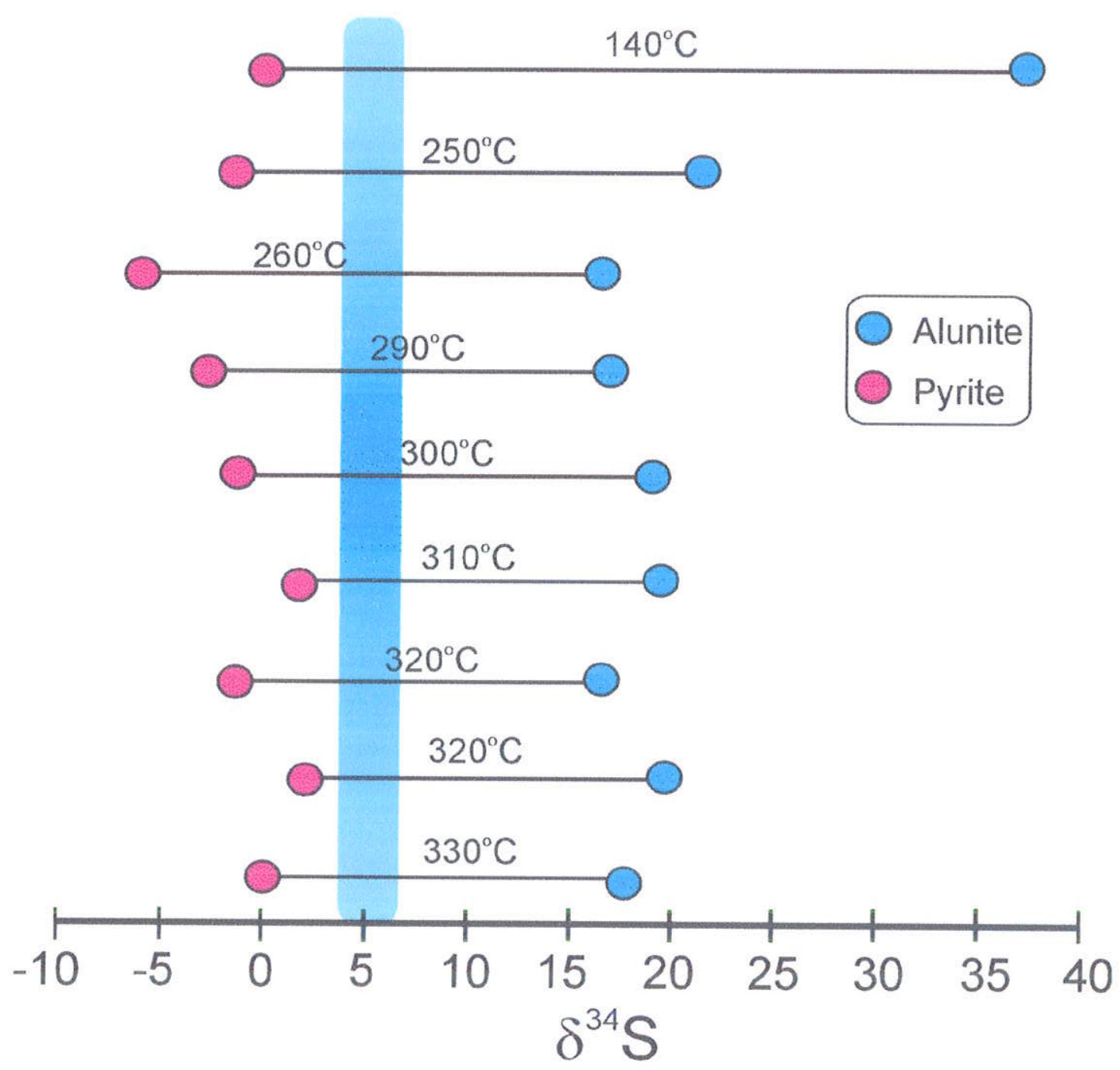

Fig. 13. $\delta^{34} S$ values of alunite and coexisting pyrite in samples from drill holes and surface sample of alunite from silica cap and assumed $\delta^{34} S$ of 1.0 permil for pyrite that has been removed by oxidation. Temperatures are based on calculations using empirical equation of Ohmoto and Rye (1979) and Ohmoto and Lasaga (1982). Note that for samples between 330 and $260^{\circ} \mathrm{C}$ most of the change of $\delta^{34} \mathrm{~S}$ values is in the sulfide, whereas for the data set as a whole most of the change is in the alunite. This probably means that the $\mathrm{H}_{2} \mathrm{~S} / \mathrm{SO}_{4}$ of the fluids was not constant and ranged from slightly $<1$ to $>1$. 
Table 5. Summary of stable isotope data for alunite and coexisting pyrite and argon age data for alunite

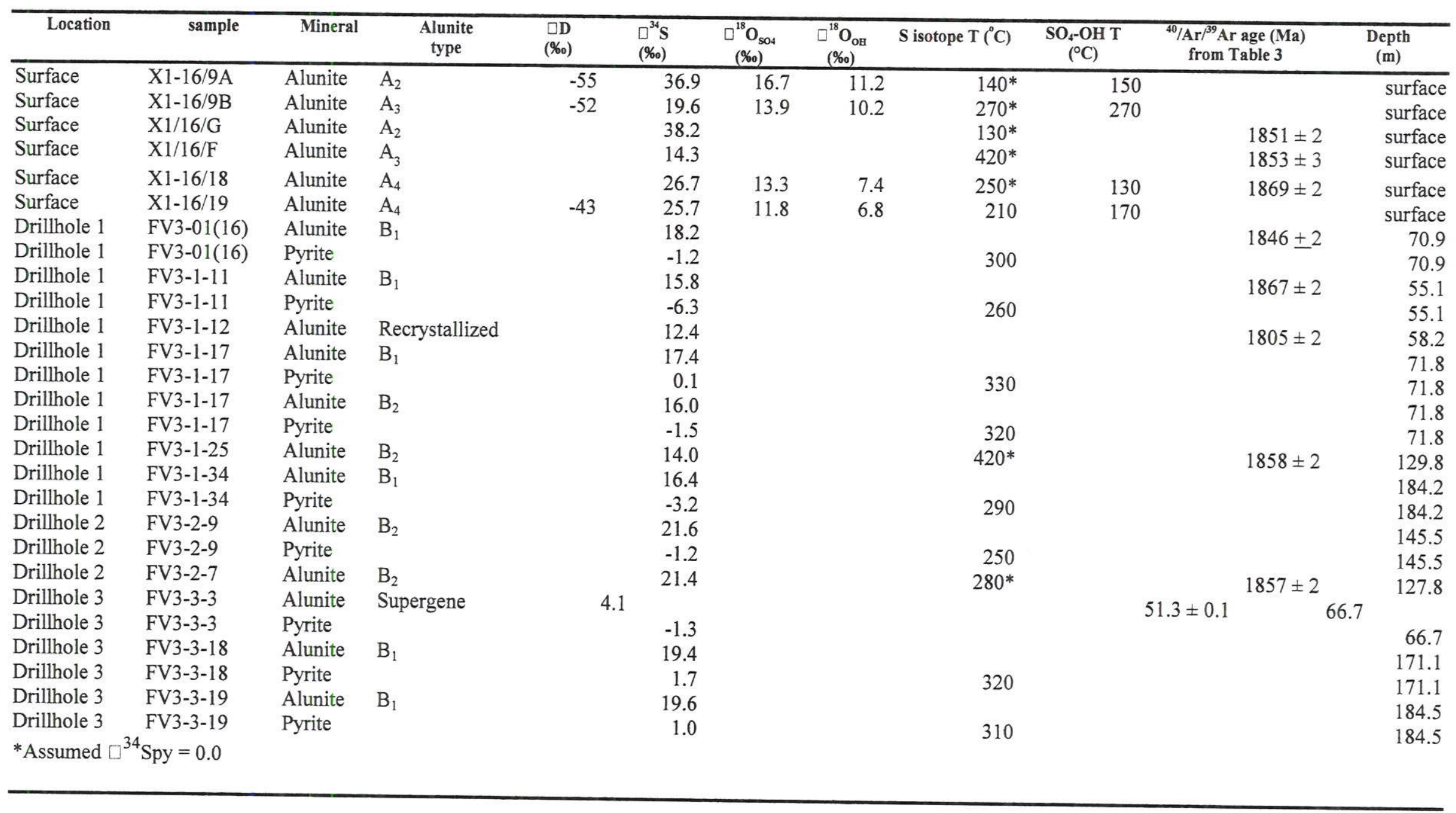


Fig. $14 \mathrm{a}$ and $\mathrm{b}$ summarizes the $\delta \mathrm{D}, \delta^{34} \mathrm{~S}$ and $\delta^{18} \mathrm{O}_{\mathrm{SO} 4}$ and $\delta^{18} \mathrm{O}_{\mathrm{OH}}$ of alunite. In Fig. $14 \mathrm{a}$ the $\delta{ }^{34} \mathrm{~S}$ versus $\delta^{18} \mathrm{O}_{\mathrm{SO} 4}$ values fall in or near the reference for magmatic hydrothermal alunite assuming a $\delta^{34} \mathrm{~S}_{\Sigma \mathrm{S}}$ of 5 and $\mathrm{H}_{2} \mathrm{~S}_{/} \mathrm{SO}_{4}$ between 1 and 8 . Those values that fall below the reference indicate minor mixing of magmatic fluids with meteoric water. All of the $\Delta^{18} \mathrm{O}_{\mathrm{SO}-\mathrm{OH}}$ fractionations give geologically reasonable temperatures. These fractionations frequently give disequilibrium values due to retrograde exchange in the $\mathrm{OH}$ site (Rye et al., 1990). The fact that these fractonations give such reasonable temperatures may indicate that they were reset uniformly during tectonic activity interpreted to result in minor argon loss in some alunites. On the other hand however, the $\Delta^{18} \mathrm{O}_{\mathrm{SO} 4-\mathrm{OH}}$ fractionation temperatures match exceptionally well with the sulfur isotope temperatures and therefore are likely primary and therefore not reset during metamorphism.
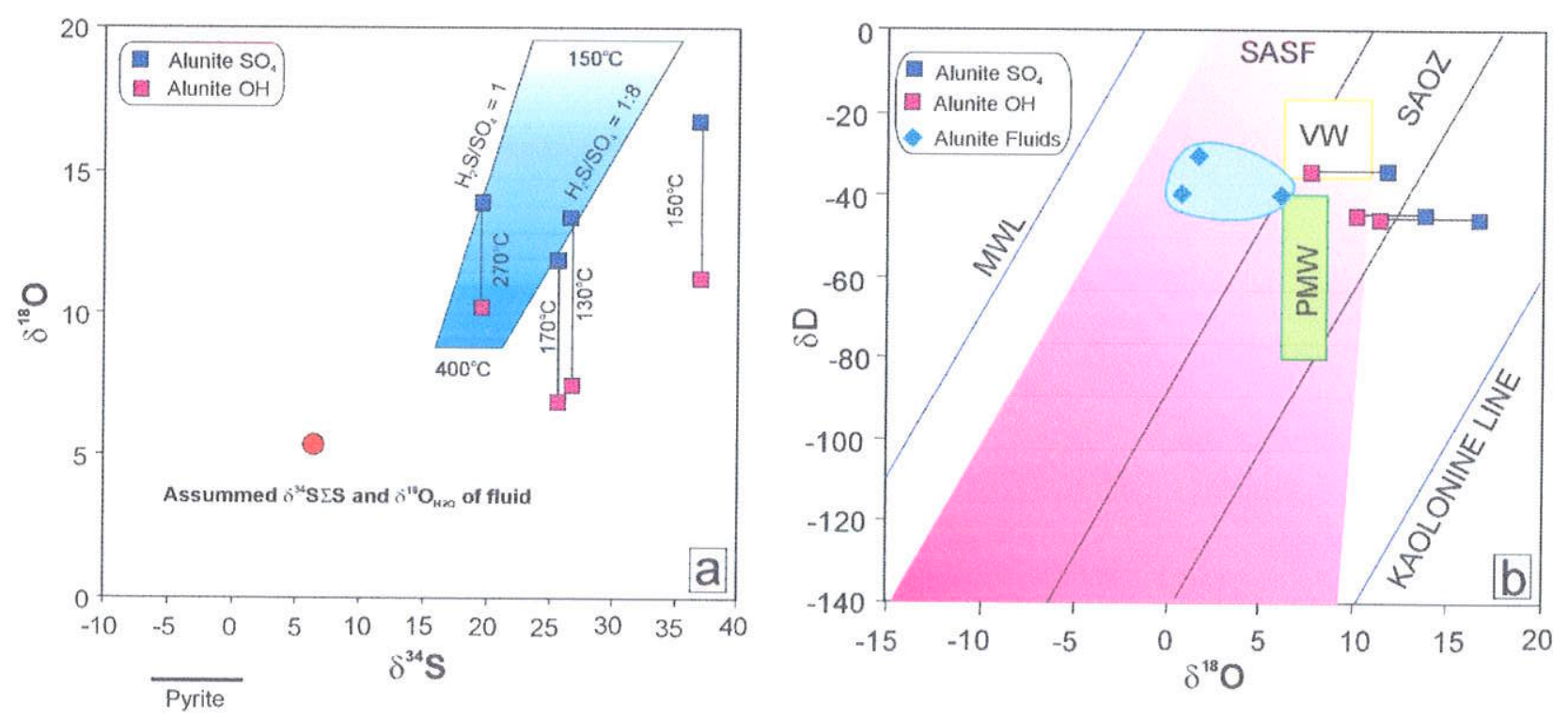

Fig. $14 \tilde{a}$ b. $\delta^{34} \mathrm{~S}, \delta^{18} \mathrm{OOH}, \delta^{18} \mathrm{OSO}_{4}$ values (a) and $\delta \mathrm{D}, \delta^{18} \mathrm{O} \mathrm{OH}, \delta^{18} \mathrm{O} \mathrm{SO}_{4}$ values (b) of alunite plotted on reference diagrams discussed by Rye et al. (1992). Tie lines between solid and open symbols in (a) represent $\delta^{8} \mathrm{O} \mathrm{SO}_{4} \mathrm{OH}$ values with temperatures calculated from experimental curves of Stoffregen et al. (1994). The polygon in (a) is the field predicted for $\delta^{34} \mathrm{~S}^{18} \delta^{18} \mathrm{O} \mathrm{OH}, \delta^{18} \mathrm{OSO}_{4}$ values of magmatic hydrothermal alunite in isotopic equilibrium with a fluid of $\delta^{18} \mathrm{O}_{\mathrm{H}_{2} \mathrm{O}}=6$ and a $\delta^{34} \mathrm{~S}_{2 \mathrm{~S}}$ of 5 at temperatures of 400 to $150{ }^{\circ} \mathrm{C}$ and $\mathrm{H}_{2} \mathrm{~S}_{\mathrm{SO}} \mathrm{SO}_{4}=1$ to 8 . Fluid composition of parent fluids in (b) are

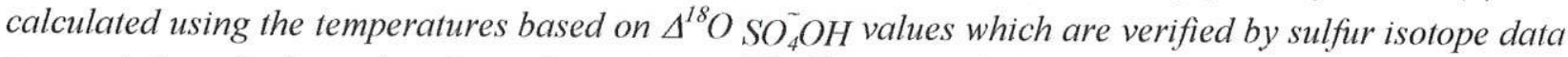
on coexisting alunite and pyrite and equations of Stoffregen et al. (1994). Some data points fall below the field due to mixing of magmatic hydrothermal fluids with meteoric water.

The $\delta \mathrm{D}$ values (Fig. 14b) are near the primary magmatic water (PMW) reference of Taylor (1968) and volcanic water (VW) reference of Giggenbach (1997) and are typical of magmatic fluids in high sulfidation systems (Rye et al., 1992; Arribas, 1995, Hedenquist et al., 
1998). The $\delta^{18} \mathrm{O}_{\mathrm{H} 2 \mathrm{O}}$ values are lower than those of typical magmatic water regardless of $\delta \mathrm{D}$ value. This difference is also typical of fluids for magmatic hydrothermal alunite and likely reflects mixing of magmatic fluids with meteoric water (Rye et al., 1992; Rye, 1993).

\section{Discussion}

The general geologic, mineralogic, and stable isotope characteristics of the sulfur-bearing minerals of the mineral occurrences in the Tapajós Gold Province are similar to those observed in many recent high-sulfidation ore deposits, such as the Tertiary Yanacocha Gold district in Peru (Harvey et al., 1999), the Miocene Summitville, Colorado, USA (Stoffregen, 1987; Rye, 1993); the Miocene Lepanto, Philippines (Hedenquist et al., 1998), the Miocene Rodolquiar, Spain (Arribas Jr. et al., 1995), as well as the Late Proterozoic Hope Brook Mine in Canada (Dubé et al., 1995). The $1.869 \pm 0.002 \mathrm{Ga}$ age of the magmatic hydrothermal alunite associated with the Tapajós high-sulfidation mineralization is consistent with a cogenetic origin with the host volcanic and igneous rocks.

The Iriri Group sequence was affected by very weak regional metamorphism that resulted in only local foliation in epiclastic volcanic rocks. Some alunite is foliated and locally sheared. Most of the alunite foliation appears to be related mainly to hydrothermal breccia flow flux but some is related to younger structural activity as evidenced by disturbed argon isotopic systematics. There is no evidence that regional metamorphism affected the primary chemical and isotopic alunite compositions.

To our knowledge, andalusite has not been described in unmetamorphosed Tertiary highsulfidation deposits. Advanced argillic alteration with andalusite has been reported at the Upper Cretaceous Chelopech Au deposit, Bulgaria (Andrew, 2002), at the latest Triassic to Middle Jurassic Limonite Creek area, British Columbia (Deyell et al., 2000), at the Paleozoic Brewer mine (Lu et al., 1992), and at the Precambrian or lower Paleozoic Mi Vida porphyry Cu deposit in Argentina (Koukharsky and Mirre, 1976). Andalusite has been associated in some of these deposits with depths below typical epithermal environment (Deyell et al., 2000; Andrew, 2002). However, in the Tapajós high-sulfidation mineralization, andalusite occurs close to the silica cap suggesting that it formed instead of kaolinite due to excess silica and relatively high temperatures (about 350. $400{ }^{\circ} \mathrm{C}$ ), as predicted by Hemley et al. (1980). These conditions are consistent with the alunite stable isotope temperatures (Fig. 13).

The high-sulfidation mineralization is closely related to calc-alkaline granite, granophyre and porphyry intrusions, which show high-temperature alkali metasomatism overprinted by propylitic and sericitic alteration similar to those described in the Batalha Granite in the Tapajós Gold Province (Juliani et al., submitted). The Batalha Granite is gold-mineralized and its 
hydrothermal system shares characteristics with porphyry $\mathrm{Cu}-\mathrm{Au}$ deposits, such as extensive $\mathrm{K}$ alteration, biotite halogen content, and base metals and gold association (Juliani et al., submitted). These characteristics could suggest that the Tapajós high-sulfidation $\mathrm{Au}$ mineralization might be genetically linked to $\mathrm{Cu}-\mathrm{Au}$ porphyry mineralization as proposed by Sillitoe (1973, 1991), Davidson and Mpodozis (1991), Hedenquist and Lowenstern (1994) and Hedenquist et al. (1998) in studies of more recent, similar tectonic settings.

A possible reason for the preservation of the Tapajós high-sulfidation mineralization from erosion and weathering could be the generation of shallow pull-apart basins in NW̃ trending shear zones after the formation of the Parauari magmatic arc evolution. Rapid burial by fluvial and shallow marine sediments favored their preservation from early weathering and erosion. Their preservation was also favored by the tectonic stability of the Tapajós Gold Province after the Parauari event. Later events had remarkably little affect on the argon retention in alunite.

There appears to be remarkably little supergene alteration of the Tapajós occurrences. Only one sample of supergene alunite (Table 4) has been discovered and it formed about $51.3 \pm$ $0.1 \mathrm{Ma}$, as previously discussed. The supergene alunite was probably formed during the early Tertiary widespread laterization in the southern Amazonian Craton (Faraco et al., 1997; Motta et al., 2000) when the deposit was unroofed. The erosion of the large areas of the volcanic sequence probably with similar epithermal Au deposits as described in this paper could result in the secondary gold concentration in alluvial and colluvial deposits, which have been mined extensively in the Tapajós Gold Province.

\section{Conclusions}

The high-sulfidation mineralization in the Tapajós Gold Province is the first such Paleoproterozoic occurrence discovered in the Amazonian Craton. Despite the poor quality of outcrops due to aggressive tropical climate and dense rain forest and the existence of few exploratory drill holes, the geologic setting, the nature of host rocks, the alteration mineralogy, the spatial relationship between hydrothermal zones, age of mineralization and stable isotopic characteristics of the high-sulfidation mineralization have been determined. This unexpected preservation of high-sulfidation occurrences opens new perspectives for precious and base metal prospecting, not only in the Amazonian Craton, but also in other old cratonic terrains.

The Tapajós high-sulfidation mineral occurrence, which contains magmatic hydrothermal alunite with ${ }^{40} \mathrm{Ar} /{ }^{39} \mathrm{Ar}$ age of $1.869 \pm 2 \mathrm{Ga}$, is related to ring composite volcanoes associated with an interpreted large ash-flow caldera complex. It consists of zones of intense silicification associated with hydrothermal breccia bodies that are covered by a hematite-rich rock interpreted 
to be a silica cap. Near the surface the breccias were affected by strong advanced argillic alteration, represented by pyrophyllite, quartz, pyrite, andalusite, diaspore, rutile, and woodhouseite-svanbergite, which envelopes alunite-rich zones with inner massive or vuggy silica, that characterize strong acid leaching. Ore minerals related to advanced argillic alteration are pyrite, covellite, bornite, enargite-luzonite, galena, chalcopyrite, sphalerite, native silver, copper, and gold. This alteration grades downwards and especially outwards to intermediate argillic, sericitic and propylitic alteration. Several generations of alunite occurred over a temperature range from about 130 to $420{ }^{\circ} \mathrm{C}$. The high temperatures indicated by some alunite and pyrite sulfur isotope fractionations and alunite $\mathrm{SO}_{4}$ and $\mathrm{OH}$ site oxygen isotope fractionations are consistent with the occurrence of andalusite in the alteration assemblages.

The Tapajós high-sulfidation mineral occurrences were apparently preserved from erosion and weathering by the development of shallow pull-apart basins in NW-SE trending shear zones following the formation of the Paraurai magmatic arc. Rapid burial by fluvial and shallow marine sediments preserved the deposits from weathering and erosion until about $51 \mathrm{Ma}$. Their preservation was also favored by the tectonic stability of the Tapajós Gold Province following the completion of the $1.87 \mathrm{Ga}$ volcanic and plutonic magmatic arc system. Only slight argon loss resulted in some samples from later tectonic activity.

\section{Acknowledgments}

We thank Fundação de Amparo à Pesquisa do Estado de São Paulo (grant 98/02567-6), PRONEX/CNPq/UFPA (662103/1998) and the Conselho Nacional de Pesquisa (CNPq )for the research scholarship granted to Carmen M.D. Nunes and Rafael H. Corrêa Silva. We are grateful to Philip M. Bethke, Charles (Skip) Cunningham and Charles H. Thorman who improved the manuscript with constructive reviews. We also thank Cyndi Kester for analyzing samples for stable isotope compositions and Ross Yeoman for argon isotopic analyses. In addition, the authors are grateful to Marcos de S. Mansueto, Dr. Excelso Ruberti, Dr. Silvio R.F. Vlach for support at the IGUSP MicroProbe Lab. and to Rio Tinto Desenvolvimentos Minerais for samples and field work support. 


\section{CAPÍTULO IV}

(Anexo II)

\section{THE BATALHA AU-GRANITE SYSTEM - TAPAJÓS GOLD PROVINCE, AMAZONIAN CRATON, BRAZIL: HYDROTHERMAL ALTERATION AND REGIONAL IMPLICATIONS}

\section{Abstract}

The Tapajós Gold Province is part of the $2.10-1.87$ Ga Ventuari-Tapajós (or TapajósParima) tectonic province of the central Amazonian craton. The Ventuari-Tapajós Province resulted from an ocean-continent orogeny, which produced two calc-alkaline magmatic arcs that are represented by the Cuiú-Cuiú complex ( 2.1-1.90 Ga) and Parauari intrusive suite ( 1.92-1.88 Ga). The Parauari magmatic event was accompanied by sedimentation and intrusion of post-tectonic $\sim 1.88$ Ga calc-alkaline granites and was followed by subalkaline and alkaline A-type magmatism related to the $\sim 1.87 \mathrm{Ga}$ Uatumã event. The $1883 \mathrm{Ma}$ Batalha granite consists of metaluminous to peraluminous, calc-alkaline to subalkaline, hornblendebiotite syeno- to monzogranites, and shows a late- to post-collisional affinity. Intense pervasive and fissural post-magmatic hydrothermal alteration, linked to gold mineralization, affected the Batalha granite. The early alteration stage involved Na metasomatism represented by crystallization of interstitial albite and replacement of plagioclase and K-feldspar by albite. Precipitation of albite caused Na impoverishment and $\mathrm{K}$ enrichment in the hydrothermal fluid, leading to microcline and biotite crystallization and pervasive replacement of older feldspars by $K$-feldspar. Pervasive and fissural propylitization overprints magmatic and early hydrothermal mineral associations, and is characterized mainly by epidote, clinozoisite, chlorite, albite, carbonate and sulphide formation. Fissural to pervasive sericitization was the last hydrothermal stage and led to crystallization of sericite, quartz and sulphide. Gold mineralization was related to the last two alteration stages, most importantly sericitization. The hydrothermal alterations were related to exsolved magmatic aqueous fluids and occurred at 500 to $290{ }^{\circ} \mathrm{C}$ and 2.6 to 1.2 kbar.

The Batalha granite shares certain characteristics with both porphyry-related systems (biotite halogen content, large alteration haloes and base metals associated with gold) and intrusion-related gold systems (reduced environment, depth of emplacement and gold mineralization associated with sericitic alteration). Classification of the Batalha gold mineralization is thus not straightforward. However, calc-alkaline to subalkaline subvolcanic granites similar to Batalha (i.e., with identical hydrothermal alteration patterns) are associated 
with Paleoproterozoic quartz-alunite high-sulphidation volcanic-hosted epithermal gold mineralization in the Tapajós Gold Province, implying coeval evolution of the hydrothermal systems. Thus, shallower and more oxidized Batalha granite may have generated porphyry CuAu type deposit. This has new implications for gold exploration in the Tapajós Gold Provinceapart from the known gold deposits within shear zones - there is high potential for low-grade, large-volume gold and base metal deposits.

Keywords: Amazonian craton; Paleoproterozoic; Granite; Hydrothermal alteration; Gold; Tapajós; Brazil

\section{Introduction}

During the 1970's and 1980's the Tapajós Gold Province (Figs. 1 and 2a) produced 150 tons of gold from more than 380 "garimpos" (small mining operations undertaken by prospectors), but systematic studies of primary ore deposits began only recently. It is now evident that there is a relationship between secondary gold deposits, regional lineaments and shear zones (Faraco et. al., 1997), especially those that cut Paleoproterozoic granitic suites (Creporizão, Parauari and Maloquinha) and volcanic rocks (Iriri Group). The Tapajós granitehosted gold mineralization has been interpreted as porphyry $\mathrm{Cu}-\mathrm{Au}$ (Coutinho et al., 1997; Jacobi, 1999), orogenic lode-gold (Goldfarb et al., 2001) and intrusion-related gold (Santos et al., 2001). Associated subvolcanic-hosted gold mineralization has been related to low-sulphidation epithermal and volcanic-hosted to high-sulphidation systems (Dreher et al., 1998; Juliani et al., 2000; Nunes et al., 2000). Gold mineralization in the Batalha granite (Fig. 2b, c) was related to pervasive post-magmatic hydrothermal alteration and may have been linked to Paleoproterozoic quartz-alunite high-sulphidation system. A late-stage phase of gold mineralization was related to shear zones (Corrêa-Silva et al., 2000).

This paper reports petrographic, mineralogical and geochemical data that constrain the genesis and evolution of hydrothermal alteration and gold mineralizations in the Batalha granite. The Batalha hydrothermal system shares characteristics with Au-rich, Cu-poor porphyry deposits (extensive hydrothermal alteration) and with intrusion-related gold systems (association with relatively reduced I-type granite). The affinity of the Batalha hydrothermal system with lowgrade, large-volume gold deposits provides a new concept for gold exploration in the Tapajós Gold Province. 


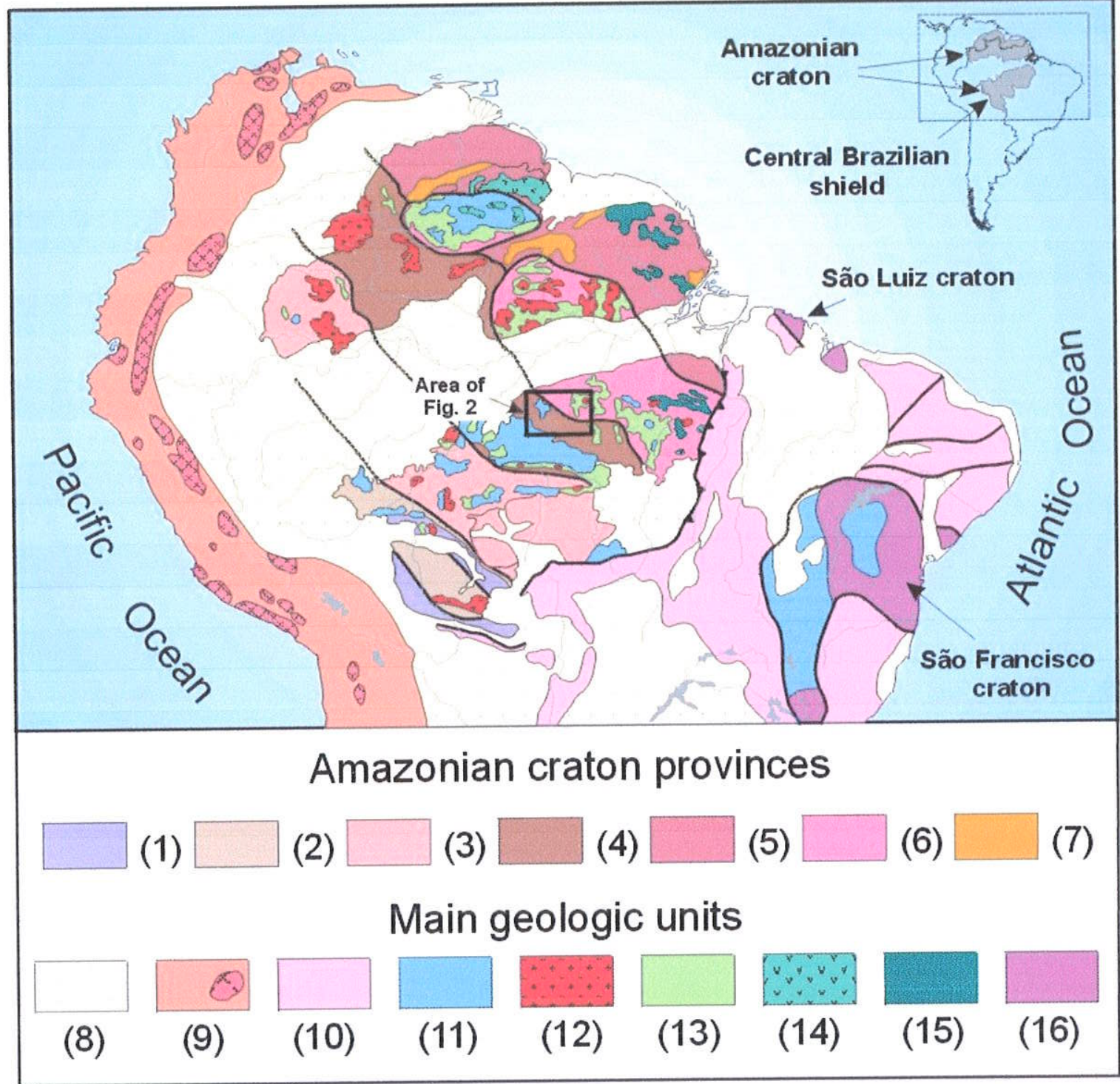

Fig. 1. Main crustal provinces of the Amazonian craton and adjacent areas: (1) Sunsás Province; (2) Rondonian-San Ignácio Province; (3) Rio Negro-Juruena Province; (4) Ventuari-Tapajós Province; (5) Maroni-Itacaiúnas Province: (6) Central Amazonian Province; (7) Granulitic complexes; (8) Cenozoic to Mesozoic sedimentary basins; (9) Andean belt showing Precambrian inliers (cross pattern); (10) Neoproterozoic mobile belts; (11) Proterozoic sedimentary basins; (12) Granitic batholits; (13) Felsic to intermediate volcanic and volcaniclastic sequences; (14) Mafic volcanic rocks; (15) Greenstone belts; (16) Granite-gneiss, granulites and granite-greenstone terrains (minor cratonic areas). Heavy continuous and dotted lines represent province borders after Tassinari and Macambira (1999), and saw-tooth line represents thrust-faults.

\section{Geological setting}

The Tapajós Gold Province is located in the Central Brazilian shield in southern Amazonian craton (Almeida et al., 1981; Fig. 1). The craton has been divided into several predominantly NW-oriented tectonic or geochronological provinces (Tassinari and Macambira, 1999; Santos et al., 2000). In these provinces, one or more orogenic events involving juvenile crust accretion, granite magmatism and tectonic reworking can be identified.

The Tapajós Gold Province is located on the boundary between the Central Amazonian Province $(>2.3 \mathrm{Ga}$ ) and the $\sim 2.10-1.87 \mathrm{Ga}$ Ventuari-Tapajós (Tassinari and Macambira, 1999; 
Fig. 1) or Tapajós-Parima (Santos et al., 2000) Province. The Central Amazonian Province is mainly composed of felsic volcano-plutonic and sedimentary units, while the Ventuari-Tapajós Province is related to an ocean-continent orogeny with shallow east-dipping subduction accompanied by sedimentation and intrusion of late- to post-tectonic calc-alkaline granites (Santos et al., 2000). The orogenic units (Fig. 2a, c; Table 1) are mainly composed of the Jacareacanga Group ( 2.10 Ga detrital zircons), which is a low-grade metamorphic volcanosedimentary sequence, and by the Cuiú-Cuiú and Parauari calc-alkaline magmatic arcs (Santos et al., 2000; Ferreira et al., 2000). The Cuiú-Cuiú arc ( 2.01-1.90 Ga) is composed of migmatites, gneisses, amphibolites and metasomatised granitoids and is cut by granites, granodiorites and tonalites of the Creporizão intrusive suite (1.97-1.90 Ga) (Ricci et al., 1999; Klein and Vasquez, 2000; Vasquez and Klein, 2000). All these rocks are intruded by granitoids of the Parauari intrusive suite $(\sim 1.92-1.88 \mathrm{Ga})$ and by gabbroic rocks of the Ingarana intrusive suite $(1.89 \mathrm{Ga})$ (Almeida et al., 2000; Bahia and Quadros, 2000).

The late- to post-orogenic volcanic rocks of the Tapajós Gold Province are represented by the Bom Jardim Formation and the Iriri Group (Fig. 2a, c; Table 1). The Bom Jardim Formation (2.00-1.88 Ga) is composed predominantly of dacitic and andesitic volcanic and volcaniclastic rocks and is stratigraphically followed by the Iriri Group; the latter is divided into the volcanic Salustiano and Aruri Formations dated at 1,88 Ga (Almeida et al., 2000; Klein and Vasquez, 2000). The Aruri Formation hosts a Paleoproterozoic gold-bearing quartz-alunite highsulphidation epithermal system (Jacobi, 1999; Juliani et al., 2000; Nunes et al., 2000).

Granite plutons of the Maloquinha intrusive suite $(\sim 1.87 \mathrm{Ga})$ cut the Iriri Group and are aligned parallel to NW-trending regional lineaments (Fig. 2a). They are mainly represented by alaskitic granites with subordinate biotite granite, amphibole-biotite granite and subvolcanic granite facies (Almeida et al., 2000; Bahia and Quadros, 2000). These granites are subalkaline to alkaline, peraluminous and similar to aluminous A-type granites, sometimes with rapakivi texture (Almeida et al., 2000; Klein and Vasquez, 2000).

The Iriri Group and the Maloquinha intrusive suite have been considered as part of the Uatumã Supergroup (Almeida et al. 2000; Klein and Vasquez, 2000). However, some authors have demonstrated the existence of at least two distinct volcanic sequences, calc-alkaline and Atype, which are neither coeval nor comagmatic (Dall'Agnol et al., 1994; 1999; Lamarão et al., submitted). The youngest geological units in the Tapajós Gold Province are fluvial to shallow marine sequences of the Buiuçu Formation and crosscutting basic rocks of the Crepori diabase and Cachoeira Seca intrusive suite (Table 1). 


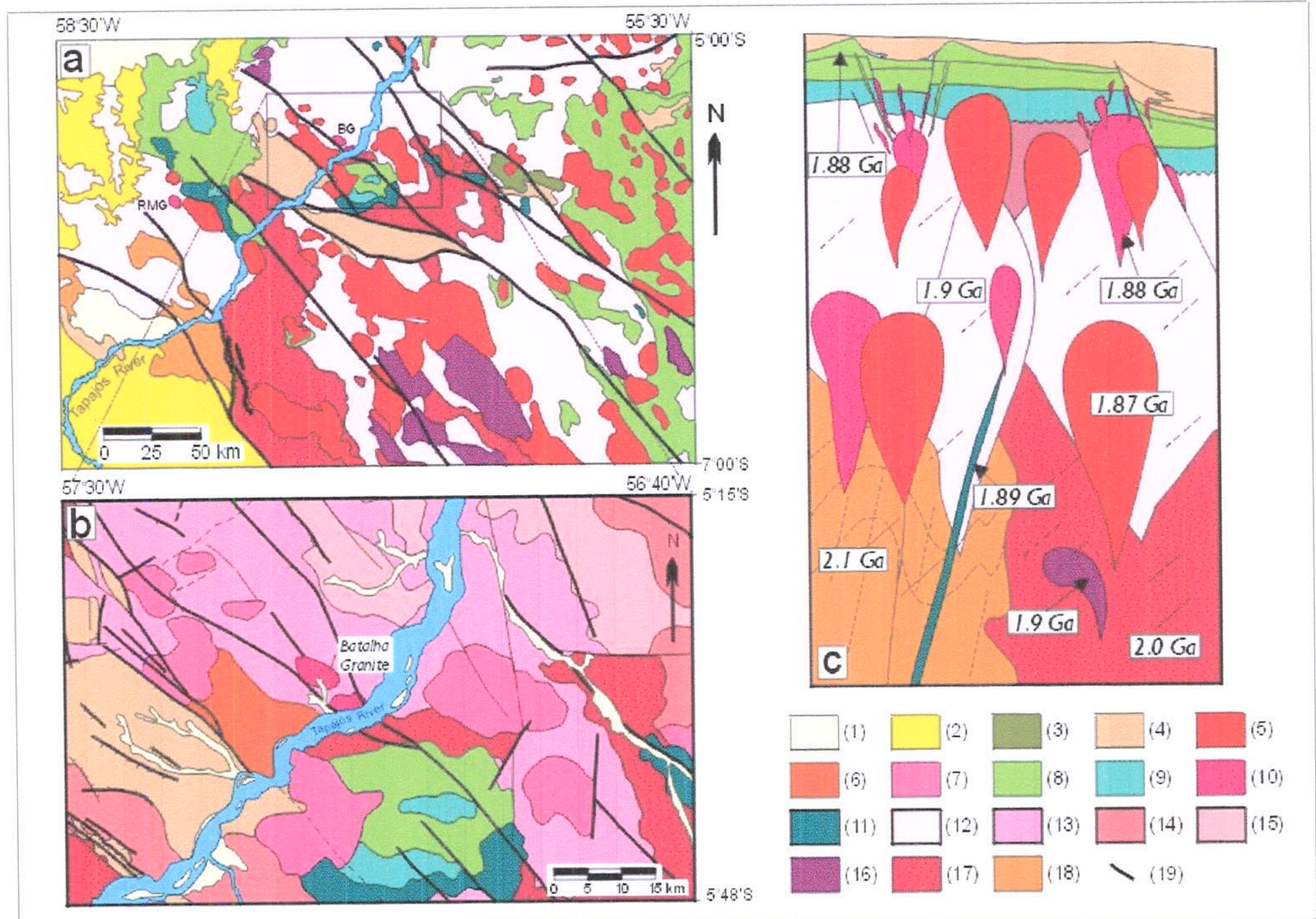

Fig. 2. (a) Geological map of part of the Tapajós Gold Province; (b) Geological map of the Batalha area (modified from Almeida et al., 2000; Bahia and Quadros, 2000; Ferreira et al., 2000; Klein and Vasquez, 2000; Vasquez and Klein, 2000). (c) Schematic stratigraphic column of the Tapajós Gold Province. (1) Cenozoic sediments; (2) Paleozoic sedimentary basins; (3) Cachoeira Seca mafic suite; (4) Buiuçu Formation; (5-7) Maloquinha intrusive suite: (5) Undivided, (6) Amphibole-biotite granite facies, (7) Biotite granite facies; (8) Iriri Group (Aruri and Salustiano formations); (9) Bom Jardim Formation; (10) Rosa de Maio (RMG) and Batalha (BG) granites; (11) Ingarana intrusive suite; (12-15) Parauari intrusive suite: (12) Undivided, (13) Granite facies, (14) Granodiorite facies, (15) Titanite granite facies; (16) Creporizão intrusive suite; (17) Cuiu-Cuiú complex; (18) Jacareacanga Group; (19) Shear zones. 
Table 1

Main geological units and geochronology of the Tapajós Gold Province

\begin{tabular}{|c|c|c|c|c|c|}
\hline Geological units & Lithology & Age (Ma) & Method & Tectonic setting & References \\
\hline Phanerozoic cover & Clastic sediments, laterite and alluvia & - & - & Intracratonic & $(6)(11)$ \\
\hline $\begin{array}{l}\text { Cachoeira Seca } \\
\text { Intrusive Suite }\end{array}$ & $\begin{array}{l}\text { Subalkaline to tholeiitic olivine gabbro, diorite, troctolites } \\
\text { and diabase }\end{array}$ & $1186 \pm 0.015$ & SHRIMP U-Pb baddeleyite & Intracratonic & $(7)$ \\
\hline Crepori Diabase & Tholeiitic augite diabase and olivine diabase & $1778 \pm 0.009$ & SHRIMP U-Pb baddeleyite & Intracratonic & $(6)(7)$ \\
\hline Buiuçu Formation & $\begin{array}{l}\text { Feldspatic sandstone, sandstone, arkose, conglomerate, } \\
\text { argillite, siltite and acid tuffs }\end{array}$ & - & - & Taphrogenic basin & $(11)$ \\
\hline $\begin{array}{l}\text { Uatumã Supergroup } \\
\text { Maloquinha Granite }\end{array}$ & $\begin{array}{l}\text { Subvolcanic subalkaline to alkaline biotite-hornblende } \\
\text { alkali-feldspar granite, syenogranite monzogranite and } \\
\text { riebeckite-arfvedsonite, micro-monzonites with rapakivi } \\
\text { textures }\end{array}$ & $\begin{array}{l}1874 \pm 0.007 \\
\text { to } \\
1870 \pm 0.004\end{array}$ & SHRIMP U-Pb zircon & $\begin{array}{l}\text { Post-collisional and } \\
\text { anorogenic }\end{array}$ & $\begin{array}{l}(1)(2)(6)(9) \\
(11)\end{array}$ \\
\hline $\begin{array}{l}\text { Iriri Group } \\
\text { Aruri Formation }\end{array}$ & $\begin{array}{l}\text { Tuffs, ignimbrites, rhyolite, volcanic breccias and } \\
\text { tuffaceous sandstones }\end{array}$ & $1877 \pm 0.004$ & $\mathrm{~Pb}-\mathrm{Pb}$ zircon evaporation & Late to post-orogenic & $\begin{array}{l}\text { (3) (6) (7) } \\
\text { (2) }(6)(7)(8) \\
\text { (9) }(11)\end{array}$ \\
\hline Salustiano Formation & $\begin{array}{l}\text { Rhyolite, rhyodacite, dacite, volcaniclastic rocks and } \\
\text { fayalite-hedenbergite rhyolites }\end{array}$ & $\begin{array}{l}1870 \pm 0.008 \\
1890 \pm 0.002\end{array}$ & $\begin{array}{l}\text { SHRIMP U-Pb zircon } \\
\mathrm{Pb}-\mathrm{Pb} \text { zircon evaporation }\end{array}$ & Late to post-orogenic & $\begin{array}{l}(6)(7)(8)(9) \\
(11)\end{array}$ \\
\hline Bom Jardim Formation & $\begin{array}{l}\text { Andesite, dacite, trachyandesite and latite, with } \\
\text { subordinated rhyolitic and basaltic flows and volcaniclastic } \\
\text { rocks }\end{array}$ & $\begin{array}{l}1888 \pm 0.007 \\
1893 \pm 0.005 \\
2001 \pm 0.006\end{array}$ & $\mathrm{~Pb}-\mathrm{Pb}$ zircon evaporation & Late to post-orogenic & $\begin{array}{l}(6)(7)(8)(9) \\
(11)\end{array}$ \\
\hline $\begin{array}{l}\text { Rosa de Maio and } \\
\text { Batalha granites }\end{array}$ & Calc-alkaline hornblende-biotite and biotite granites & $\begin{array}{l}1879 \pm 0.011 \\
1883 \pm 0.004 \\
\end{array}$ & $\begin{array}{l}\text { U-Pb zircon } \\
\text { SHRIMP U-Pb zircon }\end{array}$ & $\begin{array}{l}\text { Late- to post Parauari } \\
\text { magmatic arc (II) }\end{array}$ & $(10)$ \\
\hline $\begin{array}{l}\text { Ingarana Intrusive } \\
\text { Suite }\end{array}$ & $\begin{array}{l}\text { Subalkaline olivine gabbro, augite gabbro, norite, } \\
\text { anorthosite and ferrosilite diabase }\end{array}$ & $1893 \pm 0.003$ & SHRIMP U-Pb zircon & $\begin{array}{l}\text { Parauari arc basic } \\
\text { magmatism }\end{array}$ & (4) \\
\hline Parauari Intrusive Suite & $\begin{array}{l}\text { Porphyritic hornblende-biotite monzogranite, granodiorite, } \\
\text { syeno-granite and tonalite }\end{array}$ & $\begin{array}{l}1897 \pm 0.001 \\
1883 \pm 0.002 \\
\end{array}$ & $\begin{array}{l}\mathrm{U}-\mathrm{Pb} \text { zircon } \\
\mathrm{Pb}-\mathrm{Pb} \text { zircon }\end{array}$ & $\begin{array}{l}\text { Calc-alkaline magmatic } \\
\operatorname{arc}(\mathrm{II})\end{array}$ & $(4)(5)(6)(10)$ \\
\hline $\begin{array}{l}\text { Abacaxis and Sequeiro } \\
\text { Formations }\end{array}$ & $\begin{array}{l}\text { Pinkish siltstones, sandstone and claystone and quartz- } \\
\text { wackes }\end{array}$ & $\begin{array}{c}1895 \pm 0.009 \\
\text { to } \sim 1900 \\
\end{array}$ & U-Pb zircon & $\begin{array}{l}\text { Parauari fore- and } \\
\text { back-arc (II) basins }\end{array}$ & (6) (10) \\
\hline $\begin{array}{l}\text { Creporizão Intrusive } \\
\text { Suite }\end{array}$ & $\begin{array}{l}\text { Gneissified porphyritic syeno- and monzogranites, } \\
\text { granodiorite and tonalite }\end{array}$ & $\begin{array}{l}1968 \pm 0.019 \\
1897 \pm 0.006 \\
\end{array}$ & $\begin{array}{l}\mathrm{Pb}-\mathrm{Pb} \\
\mathrm{U}-\mathrm{Pb}\end{array}$ & Late-magmatic arc (I) & (5) (11) \\
\hline Cuiú-Cuiú Complex & $\begin{array}{l}\text { Granodioritic to tonalitic gneisses, migmatites and } \\
\text { amphibolite enclaves }\end{array}$ & $2011 \pm 0.023$ & U-Pb zircon & $\begin{array}{l}\text { Calc-alkaline magmatic } \\
\operatorname{arc}(\mathrm{I})\end{array}$ & $(7)(8)(10)(13)$ \\
\hline Jacareacanga Group & $\begin{array}{l}\text { Phyllite, schists, metaturbidite, quartzite, metabasite, and } \\
\text { BIF (low- to medium-metamorphic grade) }\end{array}$ & $\begin{array}{l}2125 \text { to } \\
2106\end{array}$ & U-Pb detrital zircon & Trench basin & $(8)(10)(11)$ \\
\hline
\end{tabular}

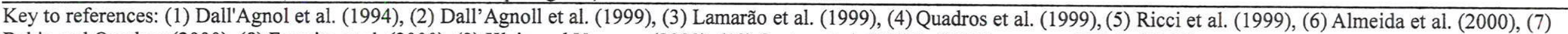
Bahia and Quadros (2000), (8) Ferreira et al. (2000), (9) Klein and Vasquez (2000), (10) Santos et al. (2000), (13) Vasquez and Klein (2000). 


\section{Geology of the Batalha area}

The Batalha granite is a $\sim 25 \mathrm{~km}^{2}$ elliptical body of hornblende-biotite granite that intrudes granites of the Parauari intrusive suite (Fig. 2b). SHRIMP U/Pb zircon age of $1883 \pm 4$ Ma determined for a granite correlated to Batalha suggests that Batalha be related to the posttectonic magmatism of the Parauari magmatic arc, represented by the $1879 \pm 11 \mathrm{Ma}$ Rosa de Maio Granite (Fig. 2a; Table 1; Santos et al., 2000).

The Parauari intrusive suite in the Batalha area is predominantly composed of biotite monzogranite, biotite-hornblende granodiorite and hornblende-biotite monzogranite, with minor alkali-feldspar granite, syenogranite, tonalite, microtonalite and granophyric monzogranite (Almeida et al., 2000). These rocks are leucocratic, grey to reddish-pink, equigranular to porphyritic, and medium- to coarse-grained. The Batalha granite and many other granites of the region are aligned in a NW-SE direction, suggesting that regional NW-trending structures controlled their emplacement (Fig. 2a).

\section{Analytical methods}

Samples were collected from outcrops in the mineralized zones of the Batalha granite and from drill cores in the sterile and mineralized zones. Geochemical studies of hydrothermally altered rocks were performed using drill core material only. Rock powders were prepared in a tungsten carbide ring mill and analyzed at ACTLABS (Activation Laboratories Inc., Ontario, Canada) after lithium metaborate or tetraborate fusion using ICP for the major elements and ICPMS for the trace elements. Mineral chemical analyses were obtained by a JEOL JXA 8600 electron microprobe at the Instituto de Geociências, Universidade de São Paulo. The wavelength dispersive technique was employed, with accelerating voltages of $15 \mathrm{kV}$, probe current of $5 \mu \mathrm{A}$, and beam diameter of $5 \mu \mathrm{m}$, except for the feldspars which were analyzed with $10 \mu \mathrm{m}$ beam.

\section{Petrography}

\subsection{Least-altered granites}

The least-altered granites are found as discontinuous and irregular bodies within hydrothermally altered zones. These granites (Fig. 3a, e) are grey to pink, massive, leucocratic to alaskitic ( $<5 \%$ of biotite and hornblende), medium- to fine-grained, and inequigranular or slightly porphyritic (locally granophyric). The modal composition is syeno- to monzogranitic (Fig. 4) and the change from the least altered to hydrothermally altered rocks is gradual.

K-feldspar is euhedral, coarse, Carlsbad-twinned, perthitic to mesoperthitic and frequently partially inverted to microcline (Fig. 5a). 

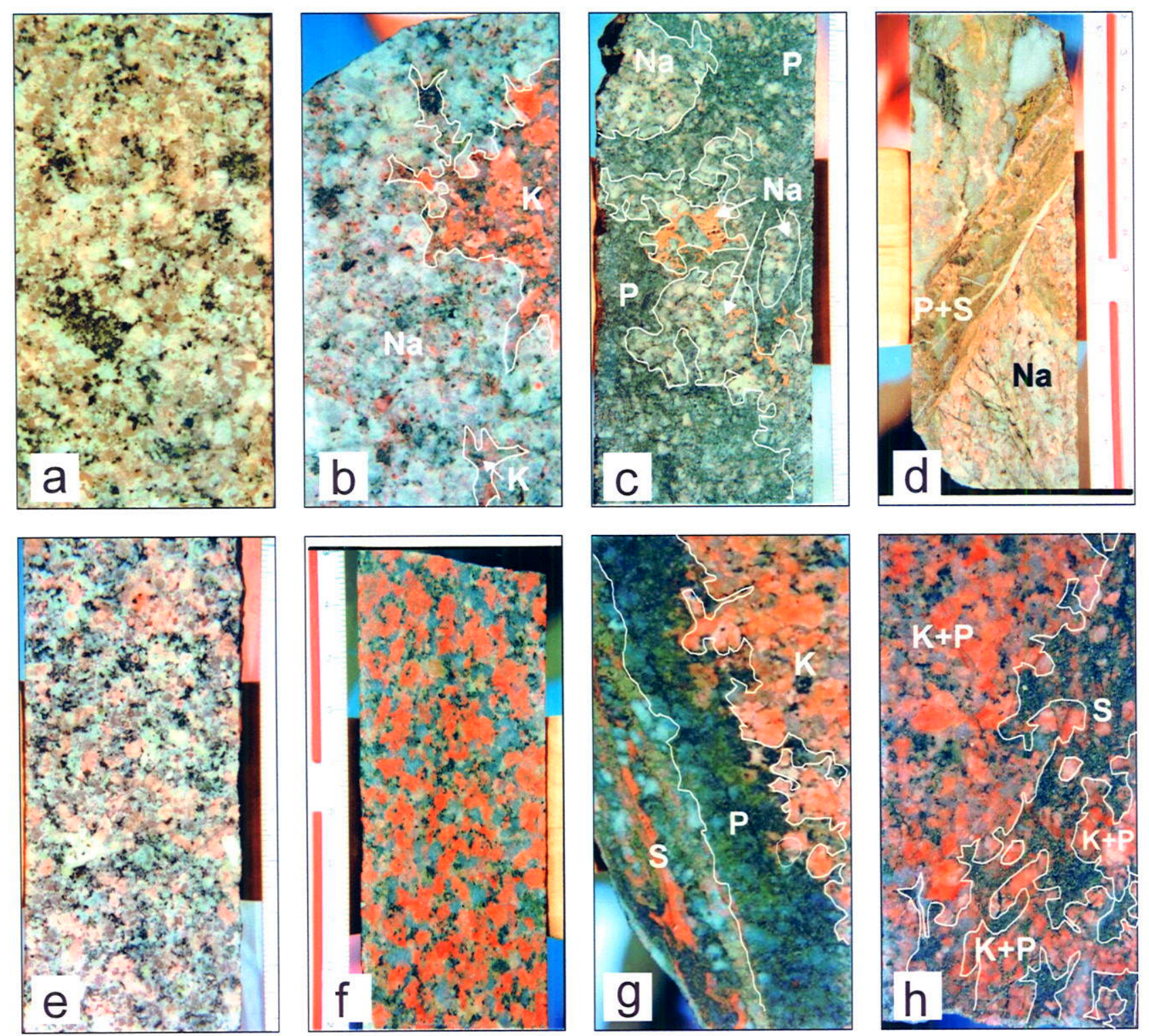

Fig. 3. Macroscopic aspects of the Batalha granites. (a through d) Alteration sequence for Na metasomatism: (a) least-altered granite with weak Na metasomatism; (b) strongly Na-altered granite (light grey) with an infiltrating zone of pervasive strong K metasomatism (dark grey); (c) Na-altered and strongly propylitized granite; (d) Na-altered granite overprinted by propylitic alteration and sericitic fissural alteration related to shear zones. (e through $h$ ) Alteration sequence for K metasomatism: (e) least-altered granite; (f) intensively $K$-altered granite; $(g)$ strongly $K$-altered granite overprinted by propylitic and sericitic fissural alteration. (h) K-altered and propylitized granite overprinted by pervasive sulphide-rich sericitic alteration. Drill core diameter is $50 \mathrm{~mm} . \mathrm{Na}=$ Na metasomatic zone; $K=K$ metasomatic zone; $P=$ 


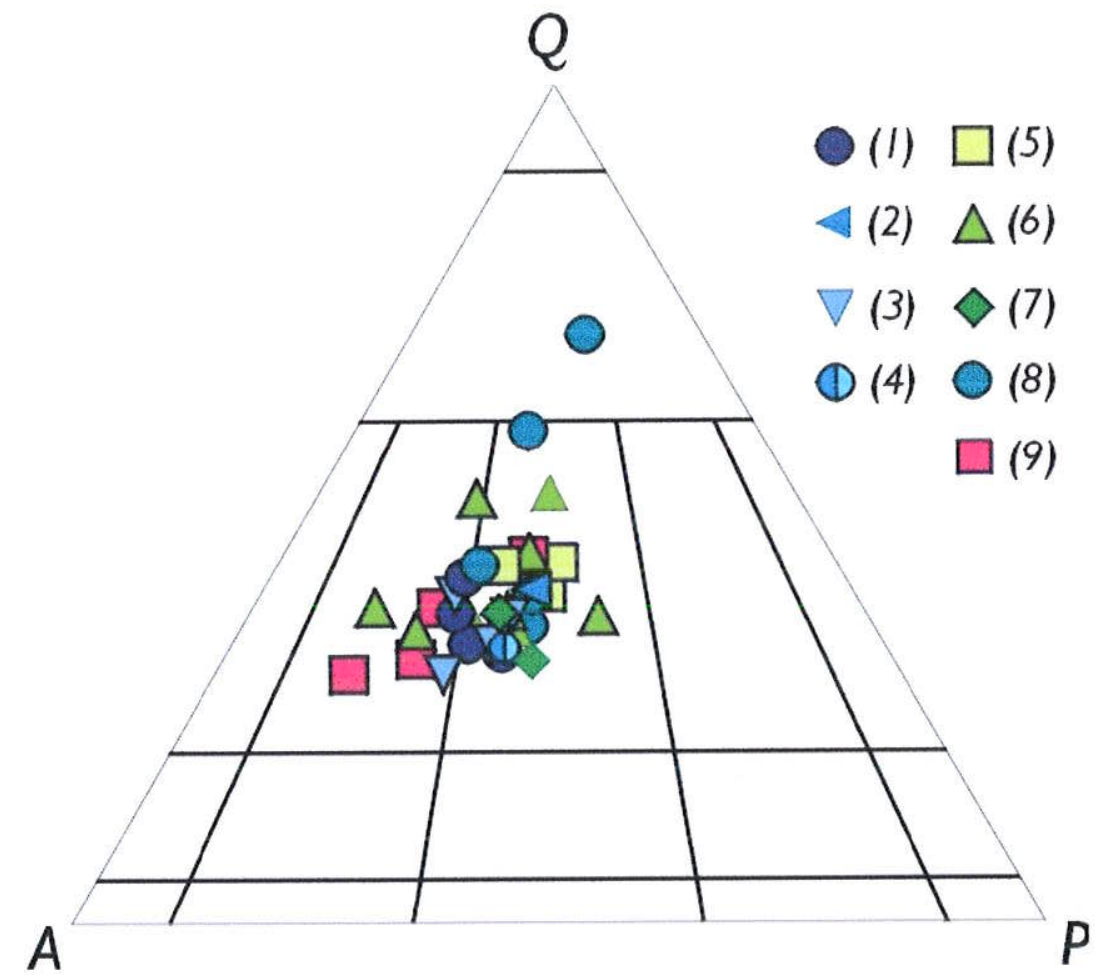

Fig. 4. QAP modal diagram for Batalha granite. Symbols: $1=$ least-altered granite; $2=$ Na-altered granite; $3=\mathrm{Na}$-and $\mathrm{K}$-altered granite; $4=\mathrm{Na}$-altered and propylitized granite; $5=\mathrm{Na}$-and $\mathrm{K}$-altered granite; $6=\mathrm{Na}$-and $\mathrm{K}$-altered and propylitized granite; $7=\mathrm{Na}$-and $\mathrm{K}$-altered and strongly propylitized granite; $8=\mathrm{Na}$-and $\mathrm{K}$-altered, propylitized, and sericitized granite; $9=\mathrm{Na}$-and $\mathrm{K}$-altered, propylitized, sericitized and carbonatized granite.

Albite exsolution is homogeneous, follows the crystallographic orientations of the host mineral, and has mainly string or stringlet, and more rarely bleb forms. Plagioclase is found as medium-sized euhedral to subhedral crystals (Fig. 5b), locally intergrown with K-feldspar at its borders. It ranges from oligoclase $\left(\mathrm{An}_{20-25}\right)$ in the cores, to albite at the rims. Some crystals have rounded or irregular nuclei isolated from an oligoclase mantle by quartz-rich inclusion zones, suggesting inheritance. Occasionally, these nuclei show weak oscillatory zoning. Incipient rapakivi textures are sometimes observed; in most cases, the plagioclase borders on K-feldspar grains can be attributed to Na metasomatism. Quartz is predominantly interstitial, in places euhedral to subhedral or skeletal, and may present undulatory extinction and corrosion textures. It commonly contains K-feldspar, oligoclase, biotite and hornblende inclusions.

The amphibole has a dark bluish-green, olive-green or brownish pleochroism. It may occur as fine-grained crystals in orthoclase, but generally forms isolated euhedral to subhedral crystals or aggregates that are partially substituted by magmatic and hydrothermal biotite (Fig. 5c). Two generations of reddish-brown magmatic biotite (Fig. 5c) are found, the older in orthoclase grains and the younger interstitial (Fig. 5d). Allanite, zircon, ilmenite and apatite are the magmatic accessory minerals. Epidote, clinozoizite, chlorite, carbonates, fluorite, sulphides, leucoxene and saussurite are secondary. 

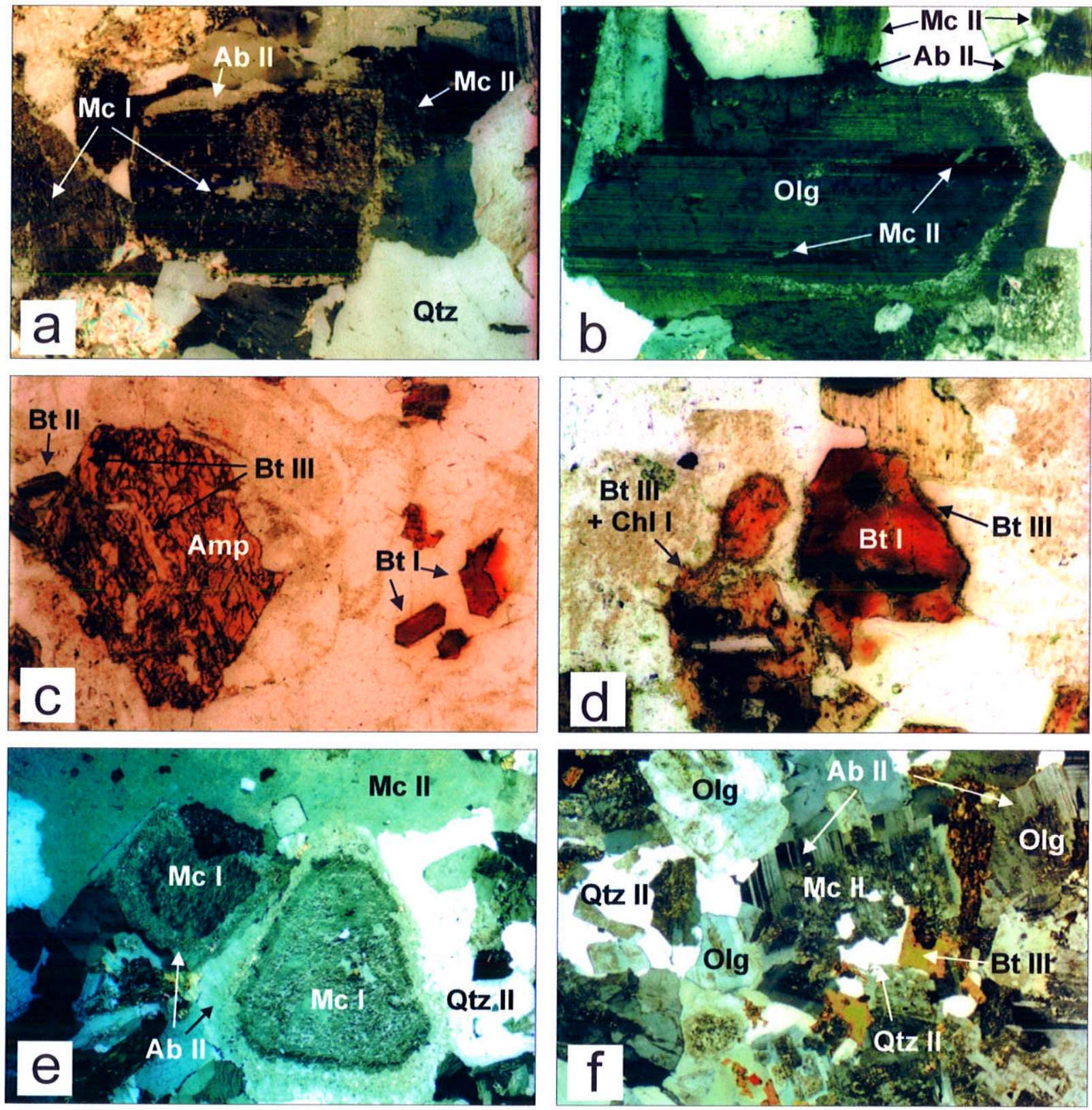

Fig. 5. Photomicrographs of magmatic and hydrothermal textures in the Batalha granite. (a) perthitic Kfeldspar inverted to microcline (Mc I) with hydrothermal albite (Ab II) rim, overprinted by hydrothermal microcline (Mc II); (b) euhedral magmatic oligoclase (Olg) with minor hydrothermal albite (Ab II) and microcline (Mc II); (c) magmatic biotite (Bt I and Bt II) and amphibole (Amp) partially replaced by hydrothermal biotite (Bt III); (d) magmatic biotite (Bt I) replaced along the rim by hydrothermal biotite (Bt III) and chlorite (Chl I); (e) perthitic K-feldspar inverted to microcline ( $M c$ I) with hydrothermal albite (Ab II) rim (i.e., rapakivi-like texture). Interstitial hydrothermal quartz (Qtz II) and microcline (Mc II) are also present; $(f)$ hydrothermal microcline (Mc II) intergrown with hydrothermal quartz (Qtz II) and biotite (Bt III) and with hydrothermal albite rims (Ab II), also present on magmatic oligoclase (Olg). Transmitted light, crossed polarisers; photo height corresponds to $3.5 \mathrm{~mm}$. 


\subsection{Altered granites}

$\mathrm{Na}$ and $\mathrm{K}$ metasomatism, propylitization and sericitization are widespread in the Batalha granite; silicification, carbonatization and sulphidization are locally present (Corrêa-Silva et al., 2000). The crystallization sequence of igneous, post-magmatic and hydrothermal minerals is presented in Fig. 6.

\subsubsection{Na metasomatism}

The earliest stage of hydrothermal alteration was pervasive $\mathrm{Na}$ metasomatism. It led to crystallization of albite as interstitial crystals and to partial to nearly complete replacement of magmatic plagioclase and K-feldspar. The contacts between hydrothermal albite and older feldspars have irregular and concave forms indicating dissolution of the pre-existing feldspar. Hydrothermal albite tends to be oriented perpendicular to the dissolution surfaces.

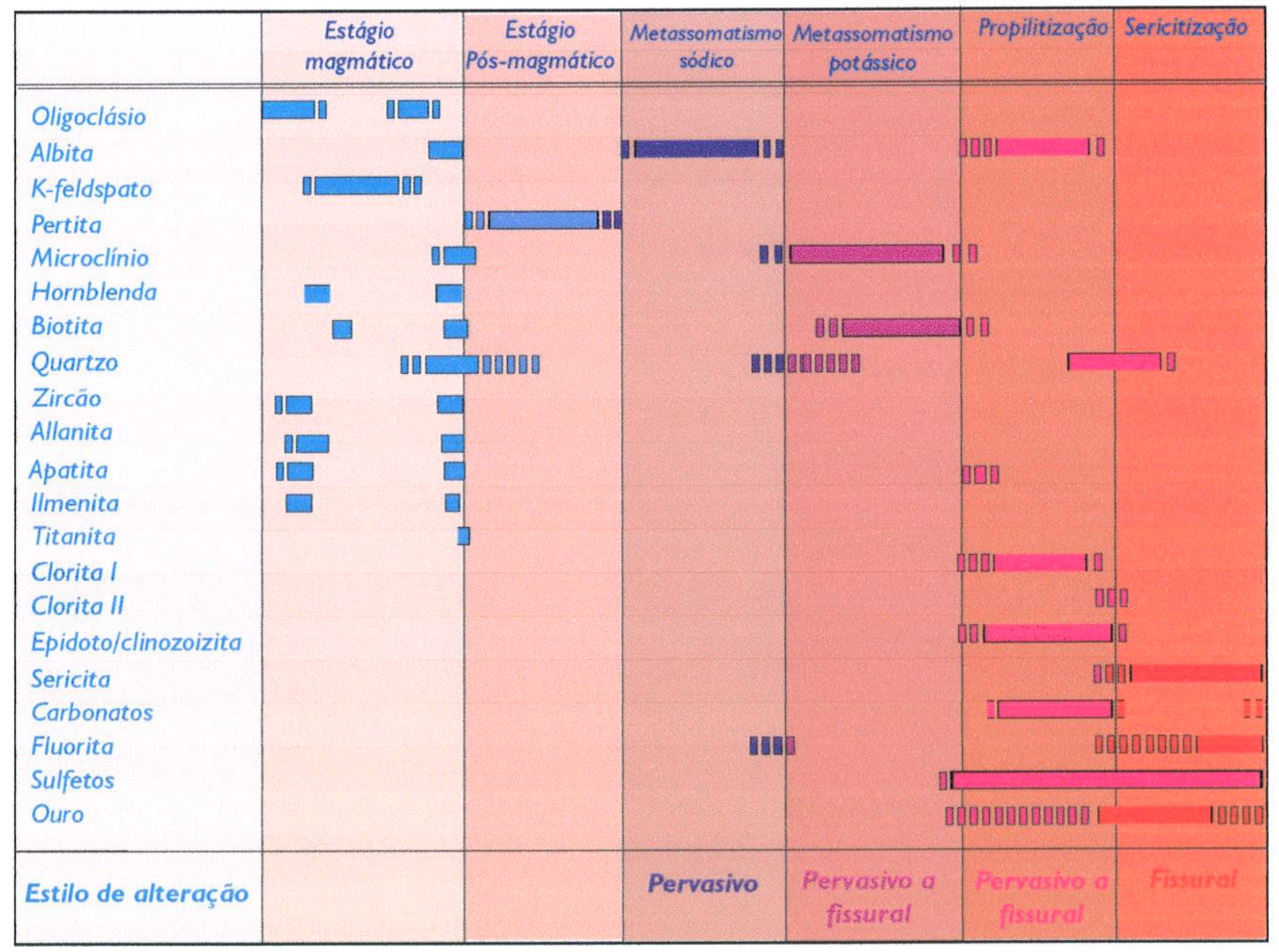

Fig. 6. Magmatic, post-magmatic and hydrothermal crystallization sequences in the Batalha granite.

The Na metasomatism also resulted in crystallization of albite on igneous plagioclase and K-feldspar (Fig. 5e). Metasomatic albite differs from igneous albite in showing discontinuous mantles, intergrowths with quartz and hydrothermal biotite (Fig. 5f) and presence of K-feldspar 
inclusions. In the perthite crystals, exsolved albite served as nuclei for crystallization of metasomatic albite and the hydrothermal albite inclusions are distinguished from subsolvus albite exsolution by their irregular nature - they do not follow the crystallographic orientations of the host mineral and may show interlocking and penetrating forms. The Na-altered rocks contain abundant fluorite and rare hornblende that is commonly replaced by biotite.

\subsubsection{K metasomatism}

Albite precipitation impoverished the hydrothermal fluid in $\mathrm{Na}$ and the fluid became enriched in $\mathrm{K}$. Thus the alkaline metasomatism turned from sodic to potassic (Fig. 3b, f), and was accompanied by pervasive and fissural silicification, mainly in fractured zones and stockworks. The main macroscopic feature of this alteration is the change of the granite colour from pink or grey to intense red. Under the microscope, this is observed as turbidity of the altered feldspars, probably owing to crystallization of fine-grained hematite (cf. Boone, 1969).

The K metasomatism was characterized by microcline and biotite crystallization (Fig. 6), and pervasive replacement of perthite and plagioclase by microcline. This resulted in irregular corroded contacts, interstitial crystals and discontinuous veins with wedge terminations. The complete replacement of both perthite and plagioclase by microcline resulted in irregular intergrowths commonly associated with quartz (Fig. 7a). Within this alteration zone, the igneous biotite and hornblende are partially or totally replaced by hydrothermal green biotite that commonly forms radial aggregates and shows leucoxene and ilmenite inclusions along cleavage planes and at grain margins. These rocks show intense sulphidization, resulting in a pyrite, pyrrhotite, chalcopyrite and bornite assemblage.

\subsubsection{Propylitic alteration}

The propylitic alteration is mainly pervasive, but also occurs as fissural, in part related to shear zones (Fig. 3g), and overprints earlier alteration types (Fig. 3c). It caused impoverishment of alkalis and enrichment of $\mathrm{H}_{2} \mathrm{O}, \mathrm{CO}_{2}$ and $\mathrm{S}$ in the lower temperature hydrothermal fluid, and is characterized by epidote + clinozoisite + chlorite $I+$ albite + carbonates \pm quartz \pm sericite \pm sulphides \pm leucoxene \pm biotite \pm fluorite \pm apatite \pm titanite assemblage.

Within this alteration zone, oligoclase cores are saussuritized and K-feldspar is variably sericitized and chloritized. Irregular microcrystalline quartz veins with diffuse contacts are also observed. Hornblende is almost totally replaced by biotite and chlorite, and early biotite shows partial or total chloritization. Allanite is always partially replaced by chlorite, epidote, clinozoisite, carbonate and sericite, and ilmenite grains have fine-grained leucoxene on the borders. 

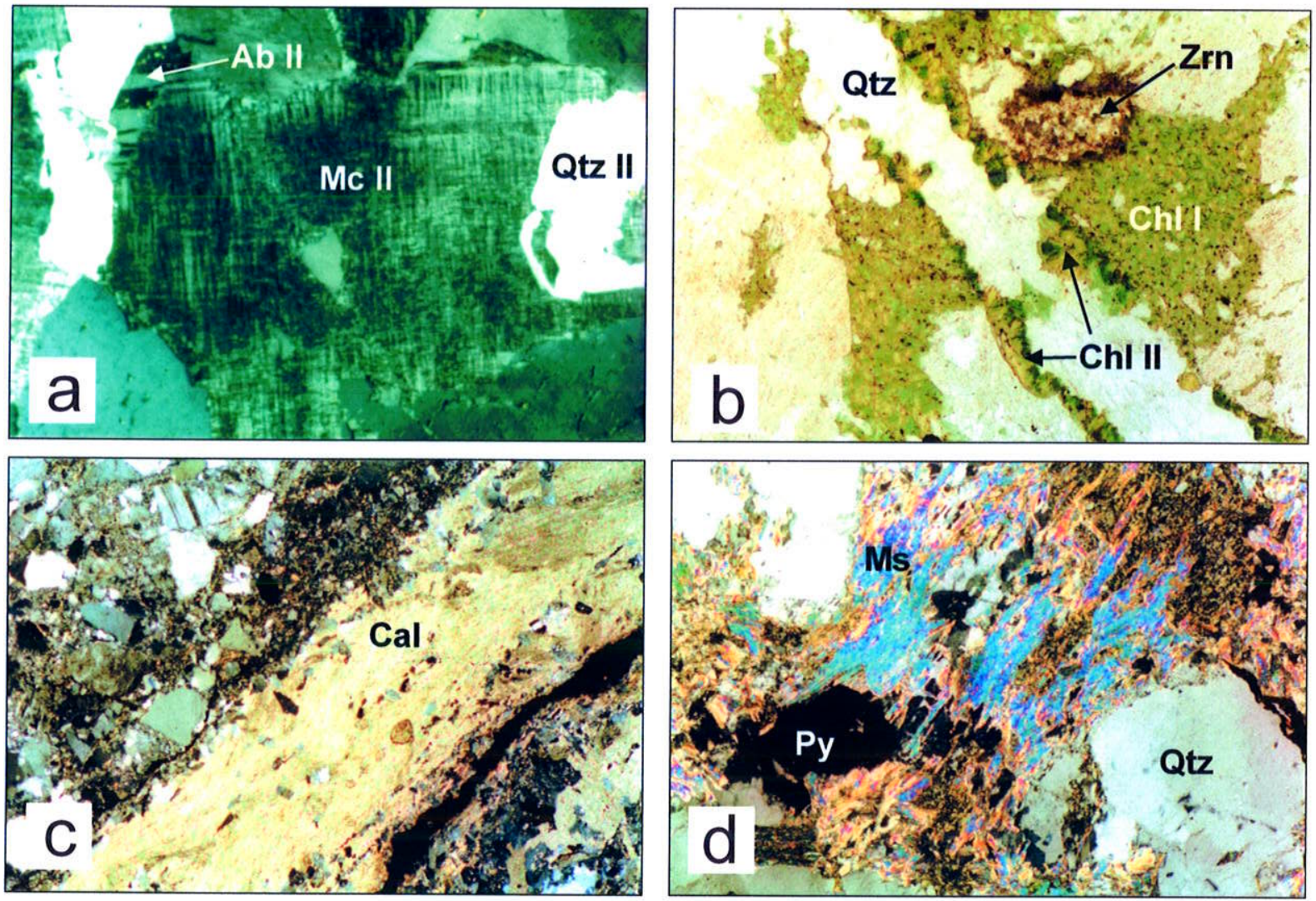

Fig. 7. Photomicrographs of hydrothermal textures in the Batalha granite. (a) Hydrothermal microcline (Mc II) with quartz intergrowth (Qtz II), and hydrothermal albite (Ab II). (b) Quartz vein with the second generation of chlorite (Chl II) transecting chlorite (Chl I) from the first propylitic alteration. (c) Calcite (Cal) vein cutting a cataclastic zone. (d) Sericite (Ms), associated with quartz and pyrite (Py), replacing plagioclase and microcline. Transmitted light, crossed polarisers; photo height corresponds to $3.5 \mathrm{~mm}$. 
Fine-grained gold inclusions $(\sim 10 \mu \mathrm{m})$ in disseminated pyrite were identified in association with hydrothermal biotite, chlorite and quartz. Close to shear zones, a second chlorite generation (chlorite II) fills fractures and interstitial spaces (Fig. 7b). Veins and fault breccia matrix (Fig. 7c) with carbonates, fluorite, milk and grey quartz, amethyst, pyrite and chalcopyrite are common. Coarse-grained gold (up to $3 \mathrm{~mm}$ ) is found in the inner parts of quartz veins with carbonate, fluorite, pyrite, chalcopyrite and chlorite.

\subsubsection{Sericitic alteration}

Sericitic alteration was the last hydrothermal stage that affected the Batalha granite. It produced a quartz, sericite, pyrite, chalcopyrite and galena assemblage that is usually found in fissures, but grades into the pervasive style (Fig. 3h) around hydrothermal veins. Intense substitution of the feldspar, especially K-feldspar, by sericite is characteristic (Fig. 7d). In the sericite-rich veins, fluorite, pyrophyllite, clay minerals, amethyst, euhedral pyrite with finegrained inclusions of gold $(\sim 10 \mu \mathrm{m})$ and barite are found. This assemblage also fills fractures associated to shear zones (Fig. 3d).

\section{Mineral chemistry}

\subsection{Amphibole}

Representative chemical compositions of igneous amphiboles from the Batalha granite are shown in Table 2. Most of them fall near the boundary between ferro-edenite and hastingsite, some indicate ferrian hastingsite compositions (Fig. 8a). The compositional variation of the amphiboles is controlled by edenitic and ferritschermakitic exchanges. The $\mathrm{Al}^{\mathrm{IV}}$ and $\mathrm{Fe}^{3+}$ contents of the majority of the amphiboles fall in the field of mid-level granitic plutons (Fig. 8b); these are considered transitional between magnetite and magnetite-free facies (Borodina et al., 1999). The ferrian hastingsite compositions are more typical of deep-level, magnetite-free granitic plutons (Fig. 8b) (Borodina et al., 1999). The $\mathrm{Fe}^{3+} /\left(\mathrm{Fe}^{3+}+\mathrm{Fe}^{2+}\right)$ ratio for these amphiboles is low, varying between 0.05 and 0.20 in the ferrian hastingsite, and reflects low- $f \mathrm{O}_{2}$ conditions during magmatic crystallization.

\subsection{Biotite}

The magmatic biotite of Batalha is annite-rich (Table 3) and has an average $\mathrm{FeO} * \mathrm{MgO}$ of 6.05; this is slightly lower than that in biotite of anorogenic suites $(\mathrm{FeO} * \mathrm{MgO}=7.04)$ and significantly higher than those in biotites for typical peraluminous (3.48) and calc-alkaline (1.76) suites (Abdel-Rahman, 1994). The $\mathrm{Mg}$ and $\mathrm{Al}_{\text {total }}$ contents of the Batalha biotite are similar to those described by Nachit (1994) for calc-alkaline and subalkaline rocks. 
Table 2

Representative amphibole compositions from Batalha Granite

\begin{tabular}{|c|c|c|c|c|c|c|c|c|c|c|}
\hline Sample & $\mathrm{P} 4-4$ & $\mathrm{P} 15-11$ & $\mathrm{P} 2-13$ & P8-7 & P19-6 & P21-8 & P2-6 & P10-11 & $\mathrm{P} 22-8$ & P5-6 \\
\hline & \multicolumn{4}{|c|}{ core } & \multicolumn{3}{|c|}{ intermediate } & \multicolumn{3}{|c|}{ rim } \\
\hline $\mathrm{SiO}_{2}$ & 38.19 & 40.25 & 41.76 & 42.25 & 40.97 & 41.74 & 40.88 & 41.15 & 42.42 & 41.84 \\
\hline $\mathrm{TiO}_{2}$ & 0.61 & 0.71 & 1.80 & 1.88 & 0.25 & 1.84 & 2.33 & 0.65 & 1.46 & 1.86 \\
\hline $\mathrm{Al}_{2} \mathrm{O}_{3}$ & 13.58 & 9.02 & 8.48 & 8.27 & 10.54 & 8.40 & 9.36 & 8.51 & 8.89 & 8.58 \\
\hline $\mathrm{FeO}$ & 28.66 & 28.79 & 27.28 & 27.30 & 27.88 & 27.56 & 26.75 & 29.34 & 27.16 & 26.67 \\
\hline $\mathrm{MnO}$ & 0.79 & 1.13 & 0.86 & 0.60 & 0.95 & 0.74 & 0.72 & 1.20 & 0.95 & 0.90 \\
\hline $\mathrm{MgO}$ & 2.55 & 3.49 & 4.23 & 4.75 & 3.96 & 4.16 & 4.51 & 3.47 & 4.10 & 4.68 \\
\hline $\mathrm{CaO}$ & 11.21 & 10.35 & 10.04 & 10.20 & 11.33 & 10.31 & 10.45 & 10.16 & 10.32 & 10.14 \\
\hline $\mathrm{Na}_{2} \mathrm{O}$ & 1.03 & 1.78 & 2.01 & 2.08 & 1.06 & 2.01 & 2.29 & 1.74 & 1.29 & 2.27 \\
\hline $\mathrm{K}_{2} \mathrm{O}$ & 1.71 & 1.24 & 1.03 & 1.04 & 1.24 & 1.04 & 0.90 & 1.17 & 1.01 & 1.04 \\
\hline $\mathrm{F}$ & 0.21 & 0.51 & 0.28 & 0.65 & 0.23 & 0.41 & 0.49 & 0.40 & 0.10 & 0.48 \\
\hline $\mathrm{Cl}$ & 0.08 & 0.23 & 0.10 & 0.13 & 0.07 & 0.14 & 0.05 & 0.19 & 0.15 & 0.13 \\
\hline Total & 98.62 & 97.50 & 97.89 & 99.14 & 98.47 & 98.35 & 98.73 & 97.98 & 97.83 & 98.59 \\
\hline \multicolumn{11}{|c|}{ Number of ions on the basis of $23(0)$} \\
\hline TSi & 5.999 & 6.460 & 6.613 & 6.620 & 6.395 & 6.604 & 6.430 & 6.555 & 6.658 & 6.590 \\
\hline $\mathrm{TAl}^{\mathrm{IV}}$ & 2.001 & 1.540 & 1.387 & 1.380 & 1.605 & 1.396 & 1.570 & 1.445 & 1.342 & 1.410 \\
\hline $\mathrm{CAl}^{\mathrm{VI}}$ & 0.514 & 0.165 & 0.196 & 0.148 & 0.335 & 0.171 & 0.165 & 0.152 & 0.303 & 0.182 \\
\hline CTi & 0.072 & 0.085 & 0.214 & 0.221 & 0.030 & 0.219 & 0.276 & 0.079 & 0.172 & 0.221 \\
\hline $\mathrm{CFe}^{3+}$ & 0.807 & 0.630 & 0.249 & 0.255 & 0.755 & 0.229 & 0.229 & 0.646 & 0.382 & 0.188 \\
\hline CMg & 0.597 & 0.835 & 0.999 & 1.110 & 0.921 & 0.982 & 1.056 & 0.825 & 0.959 & 1.099 \\
\hline $\mathrm{CFe}^{2+}$ & 2.958 & 3.234 & 3.341 & 3.266 & 2.884 & 3.399 & 3.274 & 3.263 & 3.183 & 3.310 \\
\hline CMn & 0.052 & 0.051 & 0.000 & 0.000 & 0.000 & 0.000 & 0.000 & 0.037 & 0.001 & 0.000 \\
\hline $\mathrm{BCa}$ & 1.886 & 1.779 & 1.704 & 1.713 & 1.895 & 1.748 & 1.760 & 1.733 & 1.735 & 1.712 \\
\hline $\mathrm{BNa}$ & 0.061 & 0.117 & 0.157 & 0.152 & 0.056 & 0.134 & 0.127 & 0.142 & 0.141 & 0.153 \\
\hline BMn & 0.053 & 0.103 & 0.116 & 0.079 & 0.049 & 0.099 & 0.096 & 0.145 & 0.124 & 0.121 \\
\hline $\mathrm{BFe}^{2+}$ & 0.000 & 0.000 & 0.000 & 0.056 & 0.000 & 0.019 & 0.017 & 0.000 & 0.000 & 0.015 \\
\hline $\mathrm{ANa}$ & 0.254 & 0.437 & 0.461 & 0.479 & 0.265 & 0.482 & 0.572 & 0.396 & 0.252 & 0.541 \\
\hline $\mathrm{AK}$ & 0.343 & 0.255 & 0.209 & 0.208 & 0.248 & 0.211 & 0.180 & 0.238 & 0.202 & 0.209 \\
\hline $\mathrm{CCl}$ & 0.022 & 0.062 & 0.027 & 0.034 & 0.017 & 0.036 & 0.014 & 0.051 & 0.039 & 0.035 \\
\hline $\mathrm{CF}$ & 0.104 & 0.259 & 0.139 & 0.320 & 0.111 & 0.204 & 0.246 & 0.204 & 0.048 & 0.237 \\
\hline $\mathrm{OH}$ & 1.874 & 1.679 & 1.834 & 1.646 & 1.872 & 1.760 & 1.740 & 1.745 & 1.913 & 1.728 \\
\hline
\end{tabular}



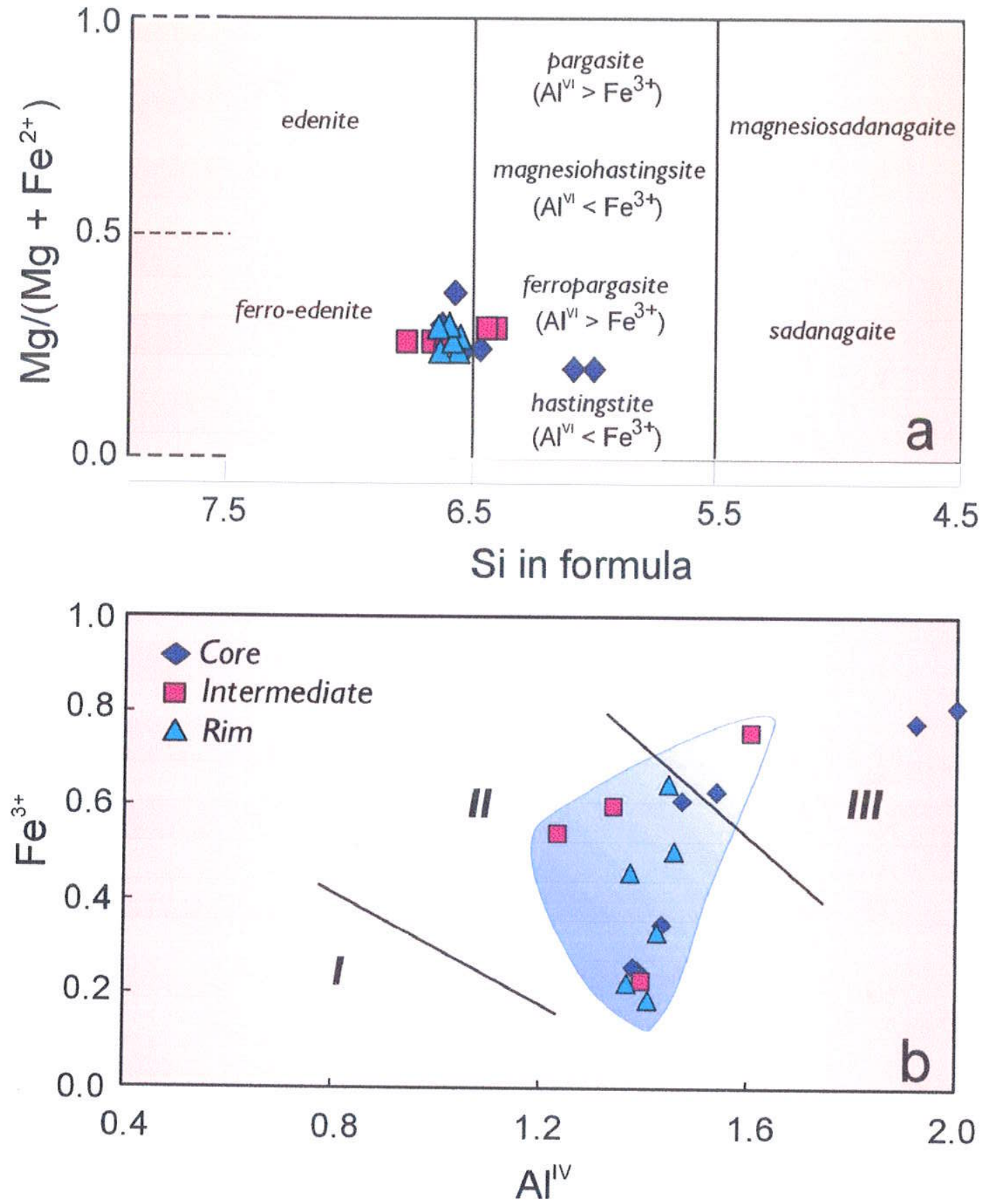

Fig. 8. (a) Classification of the amphiboles from the Batalha granite, based on Leake et al. (1997). (b) $A l^{I V}$ versus $\mathrm{Fe}^{3+}$ diagram for the Batalha amphiboles showing fields for I-high-level, II - mid-level and III - deep-level granitic plutons (Borodina et al., 1999). Ferric iron was calculated according to Schumacher (1997).

The hydrothermal biotite from Batalha is also annite-rich (Table 3) and is enriched in $\mathrm{Al}_{2} \mathrm{O}_{3}$ and $\mathrm{Fe}_{2} \mathrm{O}_{3}$ and impoverished in $\mathrm{TiO}_{2}$ (Fig. 9a, b) and $\mathrm{BaO}$ in relation to magmatic biotite. Compositions of magmatic and hydrothermal biotite indicate that the pluton crystallized close to nickel-nickel oxide (NNO) buffer (Fig. 10) and that similar conditions dominated during the post-magmatic stage. A negative correlation between $\mathrm{Fe}^{3+} /\left(\mathrm{Fe}^{2+}+\mathrm{Fe}^{3+}\right)$ and Ti content, mainly observed in hydrothermal biotite, points to small relative $\mathrm{fO}_{2}$ increase during the hydrothermal stage. 
Table 3

Representative biotite compositions from Batalha Granite

\begin{tabular}{|c|c|c|c|c|c|c|c|c|}
\hline \multirow{3}{*}{ Sample } & \multicolumn{3}{|c|}{ Magmatic biotite } & \multicolumn{5}{|c|}{ Hydrothermal biotite } \\
\hline & P36-5 & P33-9 & $\mathrm{P} 1-1$ & P30-10 & P12-4 & $\mathrm{P} 31-10$ & P24-12 & P26-16 \\
\hline & 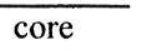 & intermediate & rim & core & \multicolumn{2}{|c|}{ intermediate } & \multicolumn{2}{|c|}{ rim } \\
\hline $\mathrm{SiO}_{2}$ & 34.86 & 34.52 & 33.39 & 34.13 & 33.97 & 34.32 & 34.75 & 34.90 \\
\hline $\mathrm{TiO}_{2}$ & 3.21 & 3.62 & 3.40 & 2.41 & 2.68 & 2.65 & 2.38 & 2.86 \\
\hline $\mathrm{Al}_{2} \mathrm{O}_{3}$ & 14.83 & 13.78 & 14.96 & 14.14 & 14.54 & 14.62 & 14.86 & 14.39 \\
\hline $\mathrm{FeO}$ & 25.25 & 25.75 & 25.74 & 25.80 & 25.87 & 25.98 & 25.42 & 25.79 \\
\hline $\mathrm{Fe}_{2} \mathrm{O}_{3}$ & 3.74 & 3.58 & 3.47 & 4.40 & 3.92 & 4.46 & 3.88 & 3.92 \\
\hline $\mathrm{MnO}$ & 0.51 & 0.56 & 0.35 & 0.52 & 0.42 & 0.50 & 0.49 & 0.54 \\
\hline $\mathrm{MgO}$ & 5.35 & 5.87 & 4.55 & 4.98 & 4.43 & 4.97 & 5.14 & 5.40 \\
\hline $\mathrm{BaO}$ & 0.02 & 0.00 & 0.00 & 0.29 & 0.07 & 0.29 & 0.16 & 0.00 \\
\hline $\mathrm{CaO}$ & 0.02 & 0.00 & 0.01 & 0.01 & 0.02 & 0.00 & 0.08 & 0.00 \\
\hline $\mathrm{Na}_{2} \mathrm{O}$ & 0.04 & 0.03 & 0.03 & 0.03 & 0.04 & 0.03 & 0.03 & 0.03 \\
\hline $\mathrm{K}_{2} \mathrm{O}$ & 9.32 & 9.30 & 9.19 & 9.00 & 9.36 & 9.09 & 9.27 & 9.10 \\
\hline $\mathrm{F}$ & 0.36 & 0.29 & 0.03 & 0.22 & 0.25 & 0.18 & 0.41 & 0.27 \\
\hline $\mathrm{Cl}$ & 0.16 & 0.16 & 0.15 & 0.20 & 0.15 & 0.13 & 0.18 & 0.15 \\
\hline $\mathrm{H}_{2} \mathrm{O}$ & 1.64 & 1.66 & 1.77 & 1.68 & 1.67 & 1.72 & 1.61 & 1.70 \\
\hline Total & 99.29 & 99.12 & 100.15 & 101.76 & 100.90 & 98.93 & 98.66 & 99.03 \\
\hline \multicolumn{9}{|c|}{ Number of ions on the basis of $11 \mathrm{O}$} \\
\hline $\mathrm{Si}$ & 2.919 & 2.903 & 2.835 & 2.896 & 2.888 & 2.891 & 2.902 & 2.900 \\
\hline AlIV & 1.081 & 1.097 & 1.165 & 1.104 & 1.112 & 1.109 & 1.098 & 1.100 \\
\hline AlVI & 0.283 & 0.267 & 0.331 & 0.309 & 0.343 & 0.312 & 0.363 & 0.308 \\
\hline $\mathrm{Ti}$ & 0.202 & 0.229 & 0.217 & 0.154 & 0.171 & 0.168 & 0.150 & 0.179 \\
\hline $\mathrm{Fe} 2+$ & 2.003 & 2.038 & 2.049 & 2.112 & 2.090 & 2.094 & 2.019 & 2.037 \\
\hline $\mathrm{Mn}$ & 0.036 & 0.040 & 0.025 & 0.037 & 0.030 & 0.035 & 0.035 & 0.038 \\
\hline $\mathrm{Mg}$ & 0.667 & 0.610 & 0.575 & 0.630 & 0.562 & 0.624 & 0.640 & 0.668 \\
\hline $\mathrm{Ba}$ & 0.000 & 0.000 & 0.000 & 0.010 & 0.002 & 0.006 & 0.005 & 0.000 \\
\hline $\mathrm{Ca}$ & 0.001 & 0.000 & 0.001 & 0.001 & 0.002 & 0.000 & 0.008 & 0.000 \\
\hline $\mathrm{Na}$ & 0.006 & 0.005 & 0.006 & 0.004 & 0.006 & 0.004 & 0.005 & 0.004 \\
\hline $\mathrm{K}$ & 0.996 & 0.998 & 0.996 & 0.974 & 1.016 & 0.976 & 0.988 & 0.965 \\
\hline $\mathrm{CF}$ & 0.188 & 0.152 & 0.013 & 0.118 & 0.133 & 0.096 & 0.214 & 0.140 \\
\hline $\mathrm{CCl}$ & 0.046 & 0.045 & 0.042 & 0.057 & 0.042 & 0.036 & 0.052 & 0.043 \\
\hline $\mathrm{OH}$ & 1.766 & 1.803 & 1.945 & 1.825 & 1.825 & 1.868 & 1.734 & 1.817 \\
\hline $\mathrm{XFe}$ & 0.770 & 0.790 & 0.810 & 0.790 & 0.810 & 0.790 & 0.790 & 0.780 \\
\hline XMg & 0.230 & 0.210 & 0.200 & 0.210 & 0.200 & 0.210 & 0.230 & 0.230 \\
\hline Xsid & 0.378 & 0.394 & 0.505 & 0.429 & 0.464 & 0.436 & 0.446 & 0.414 \\
\hline Xann & 0.392 & 0.396 & 0.295 & 0.361 & 0.336 & 0.354 & 0.324 & 0.356 \\
\hline \multicolumn{9}{|c|}{$\begin{array}{l}\text { Biotite halogen composition } \\
\mathrm{XF}\end{array}$} \\
\hline $\mathrm{XF}$ & 0.094 & 0.076 & 0.007 & 0.059 & 0.067 & 0.048 & 0.107 & 0.070 \\
\hline $\mathrm{XCl}$ & 0.023 & 0.023 & 0.021 & 0.029 & 0.021 & 0.018 & 0.026 & 0.022 \\
\hline $\mathrm{XOH}$ & 0.883 & 0.902 & 0.973 & 0.913 & 0.913 & 0.934 & 0.867 & 0.909 \\
\hline IV(F) & 1.56 & 1.64 & 2.70 & 1.75 & 1.68 & 1.84 & 1.48 & 1.70 \\
\hline IV(F/Cl) & 5.43 & 5.45 & 6.43 & 5.65 & 5.43 & 5.54 & 5.41 & 5.52 \\
\hline
\end{tabular}



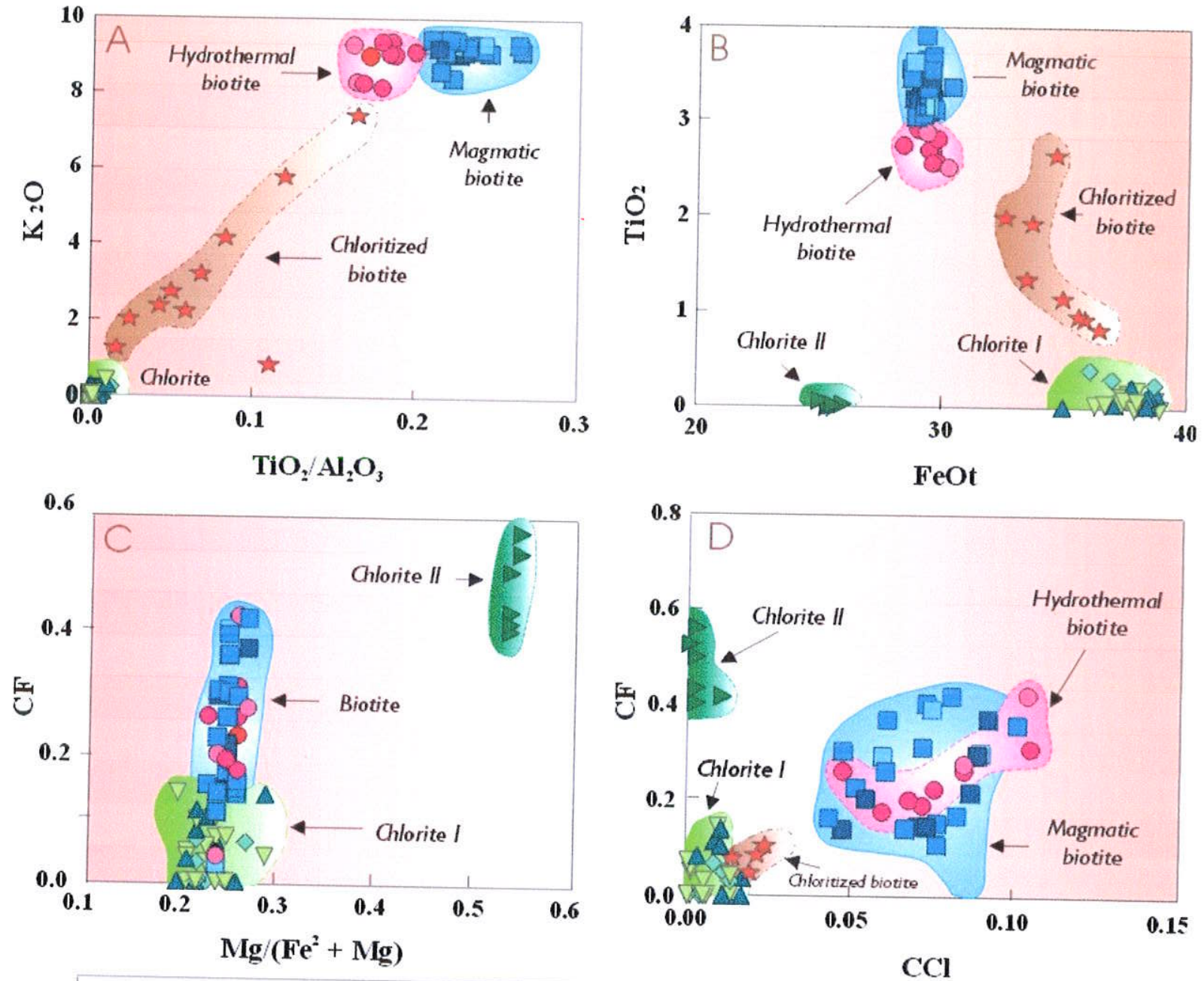

\begin{tabular}{|lll}
\hline Magmatic biotite core & Hydrothermal biotite core & Chlorite I core \\
Magmatic biotite intermediate & Hydrothermal biotite intermediate & Chlorite I intermediate \\
Magmatic biotite rim & 0 Hydrothermal biotite rim & $\nabla$ Chlorite I rim
\end{tabular}

Fig. 9. $\mathrm{K}_{2} \mathrm{O}$ versus $\mathrm{TiO}_{2} / \mathrm{Al}_{2} \mathrm{O}_{3}$ (a), $\mathrm{TiO}_{2}$ versus $\mathrm{FeO}$ tot (b), $\mathrm{CF}$ versus $\mathrm{Mg} /(\mathrm{Fe}+\mathrm{Mg}$ ) (c), and $\mathrm{CF}$ versus $\mathrm{CCl}(d)$ diagrams showing the composition of magmatic and hydrothermal biotite and chlorites from
Batalha.

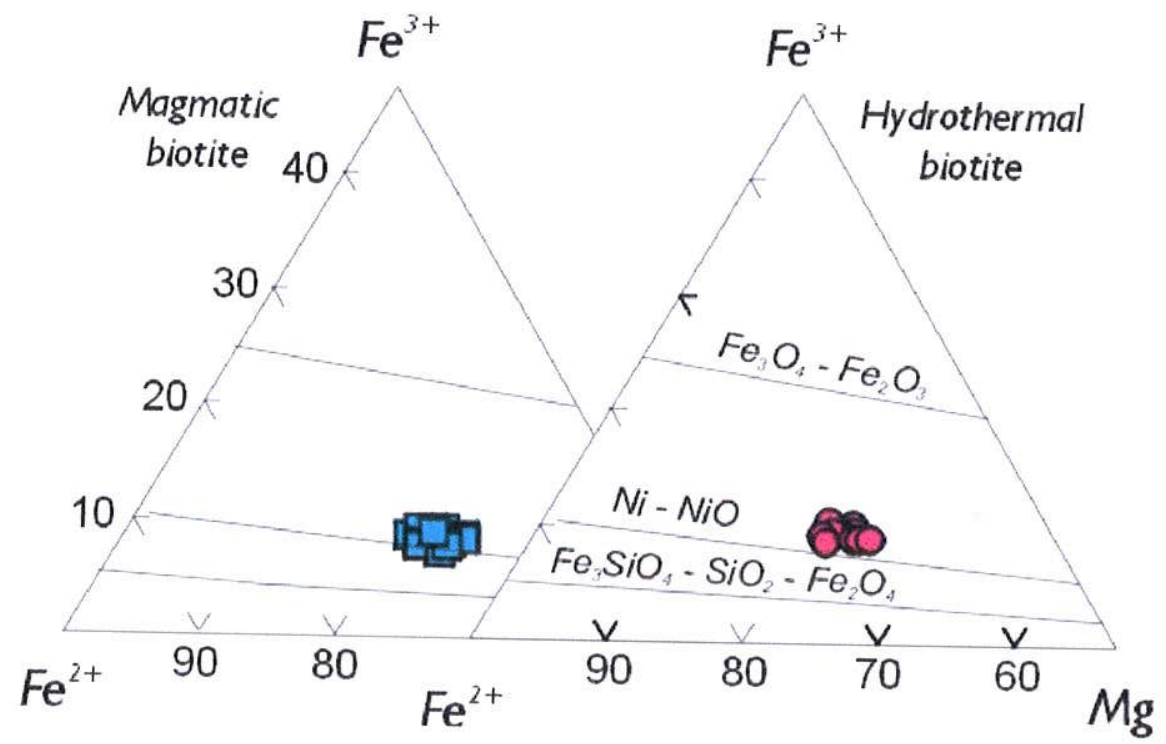

Fig. 10. Composition of Batalha biotite in terms of $\mathrm{Fe}^{3+}-\mathrm{Fe}^{2+}-\mathrm{Mg}$ (Wones and Eugster, 1965). $\mathrm{FeO}$ and $\mathrm{Fe}_{2} \mathrm{O}_{3}$ were estimated according to De Bruiyn et al. (1983). Cationic proportions based on 11 oxygens. 
The propylitization overprint affected the composition of both magmatic and hydrothermal biotite and resulted in the decrease of $\mathrm{SiO}_{2}, \mathrm{Na}_{2} \mathrm{O}$ and $\mathrm{K}_{2} \mathrm{O}$ (Fig. 9a) and increase in $\mathrm{Al}_{2} \mathrm{O}_{3}$, FeOt (Fig. 9b), $\mathrm{MnO}$ and $\mathrm{MgO}$. However, $\mathrm{Mg} /(\mathrm{Mg}+\mathrm{Fe}$ ) in the hydrothermal biotite is similar to that in magmatic biotite (Fig. 9c). The $\mathrm{CF}$ and $\mathrm{CCl}$ contents in magmatic and hydrothermal biotite are similar but are significantly lower in the chloritized biotite (Fig. 9d). The $\log \left(f \mathrm{H}_{2} \mathrm{O}\right) /(f \mathrm{HCl})$ and $\log (f \mathrm{HF}) /(f \mathrm{HCl})$ values (cf. Munoz, 1984; Zhu and Sverjenski, 1992) of the hydrothermal biotite are similar to biotite associated with K metasomatism and porphyry $\mathrm{Cu}$ deposits (Fig. 11a). The $\log \left(f \mathrm{H}_{2} \mathrm{O}\right) /(f \mathrm{HF})$ values of the Batalha biotite (Fig. 11b) are lower than those reported by Selby and Nesbitt (2000). The calculated fluorine (IV(F)) and fluorine/chlorine intercept (IV $(\mathrm{F} / \mathrm{Cl})$ ) values (Munoz, 1984) are similar to those of both porphyry $\mathrm{Cu}$ and $\mathrm{Sn}-\mathrm{W}-\mathrm{Be}$ deposits (Fig. 11c). This indicates relatively high fluorine fugacities in the hydrothermal fluid at Batalha.

\subsection{Chlorite}

Representative analyses of chlorite I (first stage of pervasive propylitic alteration) and chlorite II (late fissural and pervasive propylitic alteration) are shown in Table 4. Chlorites I and II differ in composition, and plot near the boundaries between aphrosiderite and ripidolite (chlorite I) and ripidolite and pycnochlorite (chlorite II) (Fig. 12).

$\mathrm{The} \mathrm{Mg} /(\mathrm{Mg}+\mathrm{Fe})$ ratios of chlorite I (0.20 to 0.29$)$ are close to those of coexistent biotite ( 0.19 to 0.23 ), indicating inheritance of the parent mineral chemistry, as also observed by Cathelineau (1988) for similar situations elsewhere. In chlorite II, these ratios are higher $(\sim 0.55$; Fig. 9c), reflecting extensive substitution of $\mathrm{Mg}$ by $\mathrm{Fe}$, which is accompanied by $\mathrm{Al}^{\mathrm{IV}}$ substitution for Si. The latter may be related to increase of $\mathrm{fO}_{2}$ and changes in the water-rock ratio, $f \mathrm{~S}_{2}$, $\mathrm{pH}$ or composition of the hydrothermal fluid. Chlorite I has also lower $\mathrm{F}$ contents (Fig. 9c, d) and higher Mn than chlorite II.

\subsection{Sericite}

Representative compositions of Batalha sericite are shown in Table 4. It is similar to the "secondary" muscovite of Miller et al. (1981), showing compositional variations controlled by phengitic substitution through Tschermak-type reactions related to negative correlation between $\left(\mathrm{Si}+\mathrm{Mg}+\mathrm{Fe}^{2+}\right)$ versus $\left(\mathrm{Al}^{\mathrm{IV}}+\mathrm{Al}^{\mathrm{VI}}\right)$ and $\mathrm{Al}^{\mathrm{IV}}$ versus $\left[\left(\mathrm{Al}^{\mathrm{VI}}-2\right)+(2 * \mathrm{Ti})\right]$. Compositional differences between cores and borders of sericite crystals are also observed, with larger celadonite content in the cores and enrichment in $\mathrm{Al}^{\mathrm{VI}}, \mathrm{K}$ and $\mathrm{Na}$ at the borders. This is related to paragonitic substitution. 

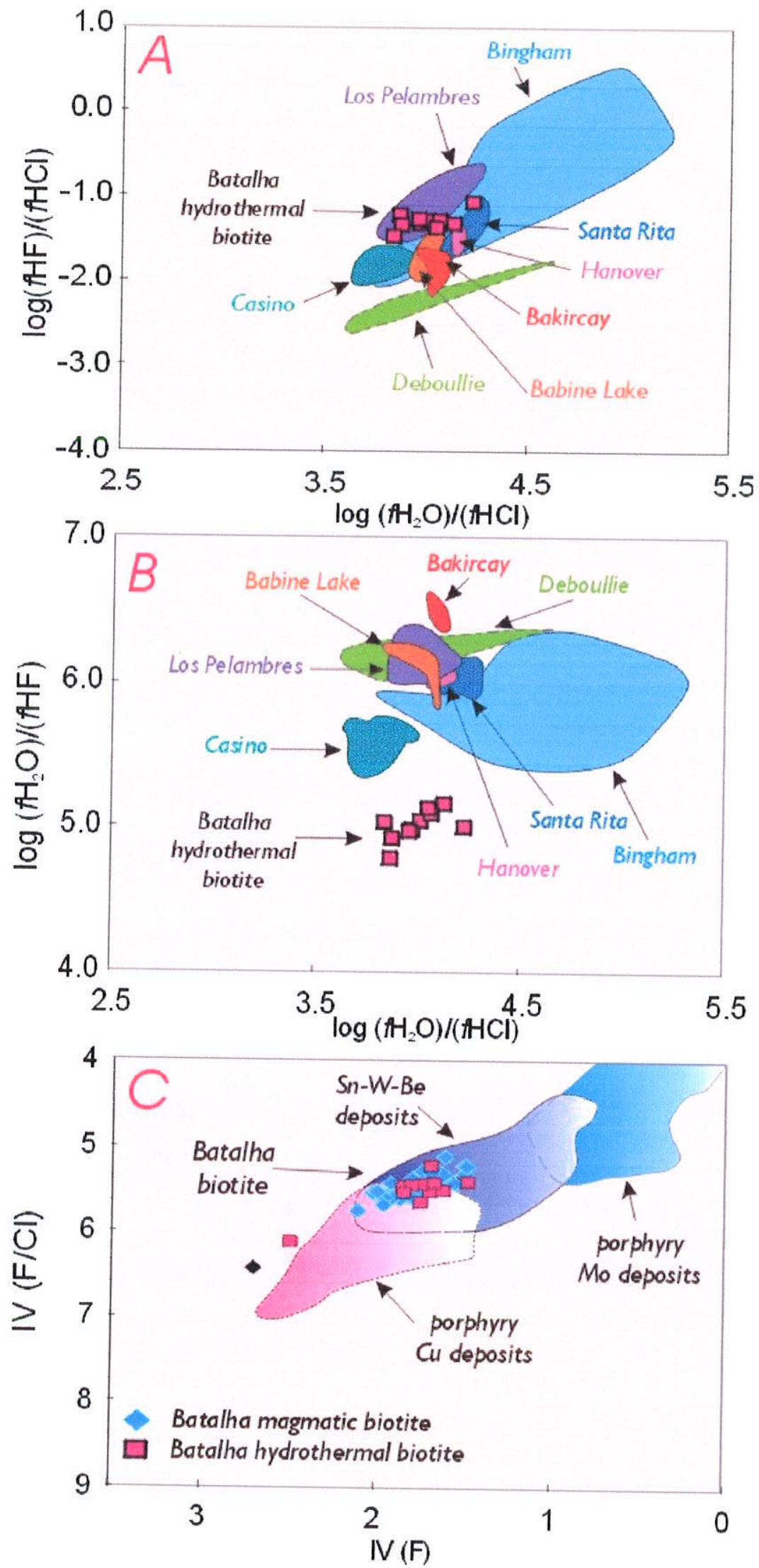

Fig. 11. Biotite halogen chemistry from Batalha, calculated on the basis of Munoz (1984) and Zhu and Sverjenski (1992) applying an estimated temperature of $490{ }^{\circ} \mathrm{C}$ (see thermobarometry further on). (a) $\log (f H F) /(f H C l)$ versus $\log \left(f H_{2} \mathrm{O}\right) /(f H C l)$ and (b) $\log \left(f \mathrm{H}_{2} \mathrm{O}\right) /(\mathrm{fHF})$ versus $\log \left(\mathrm{fH}_{2} \mathrm{O}\right) /(\mathrm{fHCl})$ diagrams showing data on Batalha granite and selected porphyry Cu deposits (see Selby and Nesbitt, 2000). (c) $I V(F)$ versus $I V(F / C l)$ plot for Batalha hydrothermal system and fields for porphyry $\mathrm{Mo}, \mathrm{Sn}-\mathrm{W}$-Be and Cu deposits (Munoz, 1984). 
Table 4

Representative chlorite and sericite compositions from Batalha Granite

Chlorite I

\begin{tabular}{rrrrr}
\hline core & & intermediate & \multicolumn{1}{c}{ rim } \\
\cline { 5 - 5 } \cline { 5 - 5 } 22.44 & $\mathrm{P} 7-2$ & & $\mathrm{P} 6-2$ & $\mathrm{P} 2-2$ \\
0.03 & 0.13 & & 23.06 & 23.68 \\
22.17 & 21.52 & 0.12 & 0.04 \\
36.29 & 37.36 & 21.35 & 20.52 \\
0.81 & 0.87 & 37.71 & 38.62 \\
6.76 & 6.00 & 0.95 & 1.23 \\
0.01 & 0.05 & 5.84 & 5.42 \\
0.01 & 0.01 & 0.05 & 0.03 \\
0.00 & 0.05 & 0.00 & 0.04 \\
0.05 & 0.00 & 0.07 & 0.07 \\
0.00 & 0.01 & 0.00 & 0.00 \\
10.71 & 10.81 & 0.01 & 0.02 \\
99.29 & 100.27 & 10.72 & 10.72 \\
& & 99.86 & 100.38
\end{tabular}

Number of ions on the basis of $36(0,0 H$

$\mathrm{Si}$

$\mathrm{Al}^{\mathrm{IV}}$

$\mathrm{Al}^{\mathrm{VI}}$

$\mathrm{Fe}^{2+}$

$\mathrm{Mn}$

$\mathrm{Mg}$

$\mathrm{Ca}$

$\mathrm{Na}$

K

$\mathrm{CF}$

$\mathrm{CCl}$

$\mathrm{OH}$

$\mathrm{X}_{\mathrm{Fe}}$

$\underline{\underline{X_{\mathrm{Mg}}}}$

$\begin{array}{rr}5.015 & 5.207 \\ 2.985 & 2.793 \\ 2.852 & 2.830 \\ 0.006 & 0.021 \\ 6.784 & 6.933 \\ 0.154 & 0.163 \\ 2.252 & 1.985 \\ 0.001 & 0.011 \\ 0.005 & 0.003 \\ 0.000 & 0.015 \\ 0.072 & 0.000 \\ 0.000 & 0.006 \\ 15.964 & 15.997 \\ 0.750 & 0.780 \\ 0.250 & 0.220\end{array}$

\section{Chlorite II}

\begin{tabular}{rrr}
\hline core & & \multicolumn{1}{c}{ rim } \\
\hline P11-3 & P12-3 & P10-4 \\
26.54 & 26.71 & 27.09 \\
0.00 & 0.02 & 0.01 \\
19.48 & 19.21 & 19.55 \\
25.40 & 25.99 & 25.75 \\
0.27 & 0.20 & 0.23 \\
17.18 & 16.97 & 16.83 \\
0.02 & 0.03 & 0.00 \\
0.02 & 0.02 & 0.00 \\
0.02 & 0.00 & 0.01 \\
0.40 & 0.33 & 0.31 \\
0.00 & 0.00 & 0.00 \\
11.35 & 11.38 & 11.47 \\
100.67 & 100.85 & 101.24
\end{tabular}

$\begin{array}{rrrrr}\text { of ions on the basis of } 36(O, O H, F) & & \\ 5.158 & 5.294 & 5.518 & 5.553 & 5.595 \\ 2.842 & 2.706 & 2.482 & 2.447 & 2.405 \\ 2.781 & 2.697 & 2.289 & 2.256 & 2.349 \\ 0.020 & 0.007 & 0.000 & 0.004 & 0.001 \\ 7.053 & 7.221 & 4.417 & 4.519 & 4.448 \\ 0.180 & 0.233 & 0.047 & 0.036 & 0.040 \\ 1.946 & 1.807 & 5.325 & 5.260 & 5.181 \\ 0.012 & 0.007 & 0.004 & 0.006 & 0.001 \\ 0.000 & 0.018 & 0.010 & 0.006 & 0.001 \\ 0.019 & 0.019 & 0.004 & 0.000 & 0.001 \\ 0.000 & 0.000 & 0.526 & 0.431 & 0.402 \\ 0.005 & 0.017 & 0.000 & 0.002 & 0.002 \\ 15.998 & 15.992 & 15.737 & 15.783 & 15.798 \\ 0.780 & 0.800 & 0.450 & 0.460 & 0.460 \\ 0.220 & 0.200 & 0.550 & 0.540 & 0.540\end{array}$

\section{Sericite}

\begin{tabular}{rrrr}
\hline & & & \\
\hline $\mathrm{P} 1$ & $\mathrm{P} 10-6$ & $\mathrm{P} 11-8$ & $\mathrm{P} 14-10$ \\
54.34 & 46.46 & 46.25 & 48.82 \\
0.09 & 0.65 & 0.02 & 0.03 \\
27.97 & 30.55 & 33.88 & 32.88 \\
2.77 & 3.52 & 1.69 & 1.32 \\
0.00 & 0.05 & 0.00 & 0.00 \\
0.85 & 2.08 & 0.98 & 0.76 \\
0.01 & 0.00 & 0.02 & 0.00 \\
0.22 & 0.14 & 0.22 & 0.21 \\
8.88 & 10.92 & 10.98 & 10.57 \\
0.27 & 0.53 & 0.31 & 0.20 \\
0.02 & 0.00 & 0.02 & 0.00 \\
4.44 & 4.14 & 4.28 & 4.40 \\
99.85 & 99.04 & 98.65 & 99.19
\end{tabular}

Number of ions on the basis of $24(\mathrm{O}, \mathrm{OH}, \mathrm{F})$

\begin{tabular}{llll}
7.127 & 6.344 & 6.259 & 6.509 \\
0.873 & 1.656 & 1.741 & 1.491 \\
3.447 & 3.257 & 3.659 & 3.672 \\
0.009 & 0.067 & 0.002 & 0.003 \\
0.304 & 0.402 & 0.191 & 0.147 \\
0.000 & 0.006 & 0.000 & 0.000 \\
0.166 & 0.423 & 0.199 & 0.150 \\
0.001 & 0.000 & 0.002 & 0.000 \\
0.057 & 0.036 & 0.059 & 0.054 \\
1.486 & 1.902 & 1.895 & 1.798 \\
0.224 & 0.457 & 0.262 & 0.167 \\
0.008 & 0.002 & 0.008 & 0.000 \\
3.884 & 3.771 & 3.865 & 3.917 \\
0.650 & 0.490 & 0.490 & 0.490 \\
0.350 & 0.510 & 0.510 & 0.510 \\
\hline
\end{tabular}




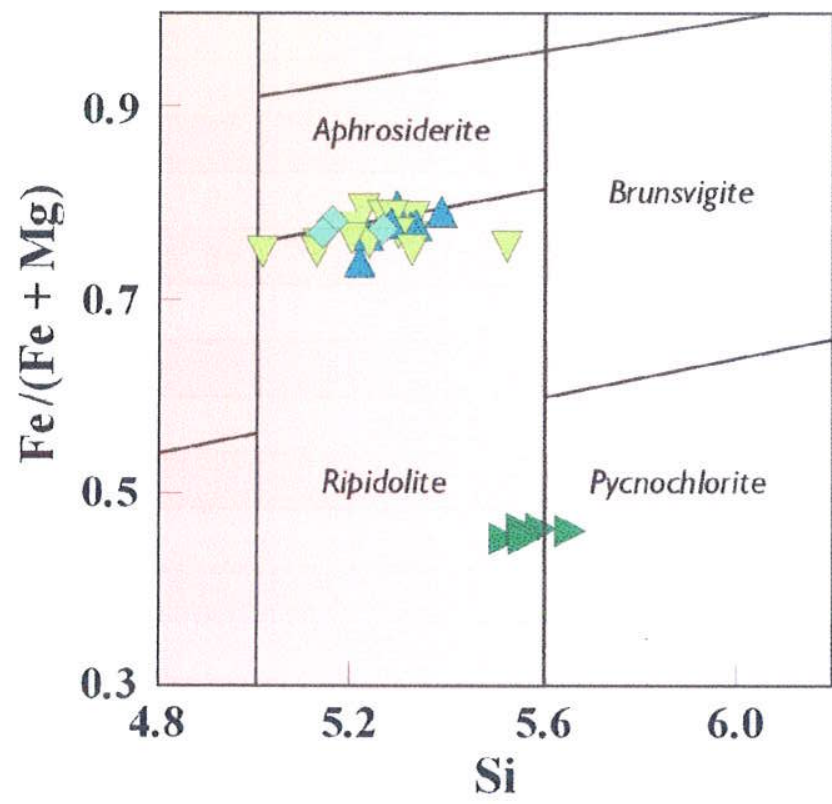

$\triangle$ Clorite I (núcleo)

$\diamond$ Clorite I (intermediária)

$\nabla$ Clorite I (borda)

$\checkmark$ Clorite II

Fig. 12. Si versus $\mathrm{Fe} /(\mathrm{Fe}+\mathrm{Mg})$ diagram showing chlorite compositions from Batalha. Classification of Hey (1954).

\subsection{Feldspars}

Magmatic plagioclase varies from oligoclase to albite (Fig. 13; Table 5) with a compositional gap that may reflect the peristerite gap. Points with an apparent composition of $\mathrm{An}_{7-10}$ probably represent small remains of magmatic oligoclase in albite.

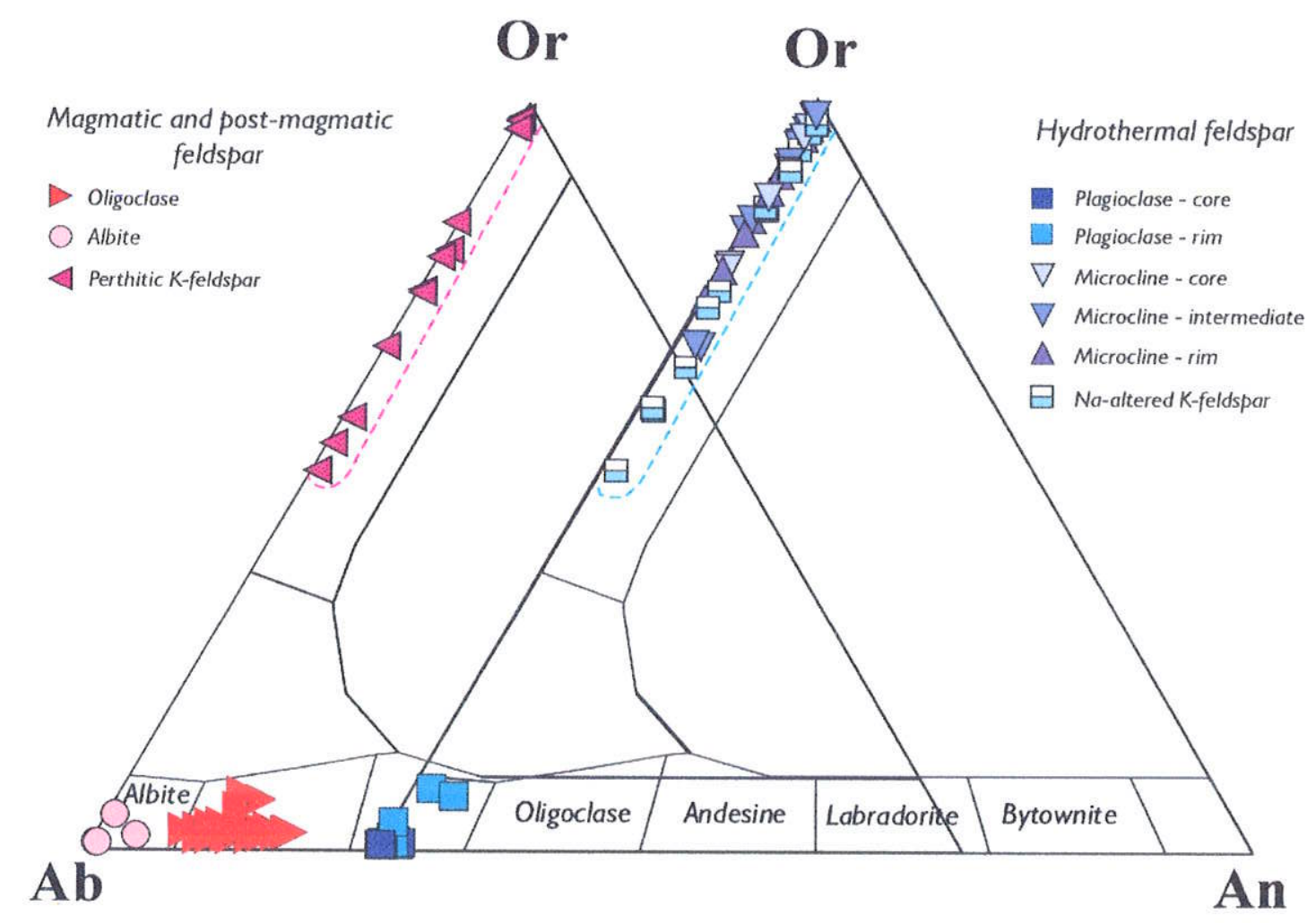

Fig. 13. Or-Ab-An diagrams showing the composition of feldspars from Batalha. 
Table 5

Representative feldspar compositions from Batalha Granite

\begin{tabular}{|c|c|c|c|c|c|c|c|c|c|c|}
\hline & \multicolumn{6}{|c|}{ Magmatic and post-magmatic feldspar } & \multicolumn{4}{|c|}{ Hydrothermal feldspar } \\
\hline & \multicolumn{3}{|l|}{ Plagioclase } & \multicolumn{3}{|l|}{ K-feldspar } & \multirow{2}{*}{$\frac{\text { Plagioclase }}{\text { Albite }}$} & \multicolumn{3}{|c|}{ K-feldspar } \\
\hline & Oligoclase & Oligoclase & Albite & $\begin{array}{c}\text { Perthitic } \\
\text { ortoclase }\end{array}$ & Perthite & $\begin{array}{l}\text { Metasomatic } \\
\text { perthite }\end{array}$ & & Albite & Microcline & Microcline \\
\hline Sample & P23-7 & P32-2 & P3-5 & P16-4 & P7 & P46-11 & P22-7 & P6-17 & P8-6 & P13 \\
\hline $\mathrm{SiO}_{2}$ & 64.89 & 64.48 & 69.23 & 65.07 & 66.10 & 65.90 & 68.17 & 69.23 & 64.84 & 64.10 \\
\hline $\mathrm{Al}_{2} \mathrm{O}_{3}$ & 22.56 & 21.86 & 19.98 & 18.84 & 18.16 & 18.87 & 19.87 & 19.84 & 18.66 & 18.33 \\
\hline $\mathrm{TiO}_{2}$ & 0.00 & 0.00 & 0.00 & 0.02 & 0.06 & 0.03 & 0.00 & 0.00 & 0.00 & 0.00 \\
\hline $\mathrm{Fe}_{2} \mathrm{O}_{3}$ & 0.13 & 0.19 & 0.15 & 0.09 & 0.06 & 0.03 & 0.07 & 0.08 & 0.11 & 0.21 \\
\hline $\mathrm{MnO}$ & 0.02 & 0.03 & 0.00 & 0.01 & 0.03 & 0.00 & 0.02 & 0.01 & 0.03 & 0.00 \\
\hline $\mathrm{MgO}$ & 0.00 & 0.00 & 0.00 & 0.01 & 0.01 & 0.00 & 0.02 & 0.00 & 0.05 & 0.00 \\
\hline $\mathrm{CaO}$ & 3.42 & 3.42 & 0.08 & 0.00 & 0.08 & 0.02 & 0.23 & 1.56 & 0.00 & 0.00 \\
\hline $\mathrm{SrO}$ & 0.06 & 0.00 & 0.00 & 0.00 & 0.00 & 0.01 & 0.00 & 0.00 & 0.00 & 0.00 \\
\hline $\mathrm{BaO}$ & 0.03 & 0.00 & 0.00 & 0.46 & 0.20 & 0.49 & 0.00 & 0.00 & 0.20 & 0.14 \\
\hline $\mathrm{Na}_{2} \mathrm{O}$ & 9.71 & 9.00 & 11.60 & 0.46 & 2.83 & 3.14 & 11.70 & 10.36 & 0.37 & 0.19 \\
\hline $\mathrm{K}_{2} \mathrm{O}$ & 0.43 & 1.34 & 0.07 & 16.50 & 12.62 & 12.29 & 0.29 & 0.11 & 16.49 & 16.24 \\
\hline Total & 101.26 & 100.31 & 101.11 & 101.46 & 100.14 & 100.77 & 100.38 & 101.19 & 100.74 & 99.22 \\
\hline \multicolumn{11}{|c|}{ Number of ions on the basis $32 \mathrm{O}$} \\
\hline $\mathrm{Si}$ & 11.331 & 11.394 & 11.953 & 11.915 & 12.055 & 11.959 & 11.896 & 11.947 & 11.935 & 11.963 \\
\hline $\mathrm{Al}$ & 4.640 & 4.549 & 4.062 & 4.062 & 3.899 & 4.032 & 4.083 & 4.033 & 4.045 & 4.029 \\
\hline $\mathrm{Fe}^{3+}$ & 0.017 & 0.025 & 0.020 & 0.013 & 0.008 & 0.004 & 0.010 & 0.010 & 0.016 & 0.030 \\
\hline $\mathrm{Ti}$ & 0.000 & 0.000 & 0.000 & 0.003 & 0.008 & 0.004 & 0.000 & 0.000 & 0.000 & 0.000 \\
\hline $\mathrm{Mn}$ & 0.002 & 0.004 & 0.000 & 0.002 & 0.005 & 0.000 & 0.002 & 0.001 & 0.005 & 0.000 \\
\hline $\mathrm{Mg}$ & 0.001 & 0.000 & 0.000 & 0.002 & 0.002 & 0.000 & 0.006 & 0.000 & 0.012 & 0.000 \\
\hline $\mathrm{Sr}$ & 0.010 & 0.000 & 0.000 & 0.000 & 0.000 & 0.000 & 0.000 & 0.000 & 0.000 & 0.000 \\
\hline $\mathrm{Ba}$ & 0.002 & 0.000 & 0.000 & 0.033 & 0.015 & 0.035 & 0.000 & 0.000 & 0.014 & 0.010 \\
\hline $\mathrm{Ca}$ & 0.640 & 0.647 & 0.014 & 0.000 & 0.016 & 0.004 & 0.043 & 0.289 & 0.000 & 0.000 \\
\hline $\mathrm{Na}$ & 3.288 & 3.085 & 3.883 & 0.163 & 1.002 & 1.104 & 3.959 & 3.467 & 0.131 & 0.069 \\
\hline K & 0.096 & 0.301 & 0.016 & 3.853 & 2.935 & 2.846 & 0.064 & 0.024 & 3.872 & 3.867 \\
\hline $\mathrm{Ab}$ & 81.7 & 76.5 & 99.2 & 4.1 & 25.3 & 27.9 & 97.4 & 91.7 & 3.3 & 1.8 \\
\hline An & 15.9 & 16.0 & 0.4 & 0.0 & 0.4 & 0.1 & 1.1 & 7.6 & 0.0 & 0.0 \\
\hline Or & 2.4 & 7.5 & 0.4 & 95.9 & 74.2 & 72.0 & 1.6 & 0.6 & 96.7 & 98.2 \\
\hline
\end{tabular}


Microprobe analyses of pertithic feldspar were performed on the igneous and Na-altered host $\mathrm{K}$-feldspar in domains where albite exsolution was not recognized. Igneous $\mathrm{K}$-feldspar has a lower alkali content and slightly higher Ca content than hydrothermal K-feldspar (Table 5); both show distinct linear trends of substitution between $\mathrm{K}$ and $\mathrm{Na}$. The hydrothermal microcline is more homogeneous than the igneous $\mathrm{K}$-feldspar and shows a trend of $\mathrm{Na}$ and $\mathrm{K}$ contents concordant with the compositional variation of the albitized K-feldspar. This suggests a link between $\mathrm{Na}$ alteration and microcline crystallization related to the evolution of the hydrothermal fluid.

\section{Thermobarometry for magmatic and hydrothermal assemblages}

The crystallization conditions of the Batalha granite were estimated using an internally consistent thermodynamic database (TWQ software; Berman, 1991) considering plagioclase, biotite and amphibole in equilibrium with quartz and $\mathrm{K}$-feldspar at $\mathrm{X}_{\mathrm{H} 2 \mathrm{O}}=1$. The best estimates for the conditions of formation of the magmatic mineral assemblage (plagioclase core + biotite + amphibole core $+\mathrm{K}$-feldspar + quartz) range between 955 and $800{ }^{\circ} \mathrm{C}$ and 5.6 and $4.2 \mathrm{kbar}$ (Fig. 14a). However, the magmatic minerals show different degrees of chemical disequilibrium indicated by the dispersion of the calculated reactions. This is probably caused by reequilibration during cooling and hydrothermal alteration and results in calculated temperatures of 967-707 ${ }^{\circ} \mathrm{C}$ and pressure of 5.7-2.5 kbar (Fig. 14a). The re-equilibration of biotite is generally very effective in the presence of hydrothermal fluids, as shown by the strong recrystallization of the biotite to chlorite, even when the amphiboles are preserved. This disequilibrium is reflected by the displacement of the tschermakite + annite $=$ phlogopite + Fe-tschermakite reaction to temperatures of $600-450{ }^{\circ} \mathrm{C}$ at $2.5 \mathrm{kbar}$ (Fig. 14a). The neoformed K-metasomatic minerals are in chemical equilibrium with amphibole rims, except for the phlogopite end-member. In this case, phlogopite activity was estimated to be $\sim 0.7$ using activity-temperature diagrams. Thus, the K-metasomatic assemblage probably reached equilibrium at $2.6 \mathrm{kbar}$ and $492{ }^{\circ} \mathrm{C}$ (Fig. 14b).

The depth of the emplacement of the Batalha granite was also estimated using the Al-inhornblende barometer (Hammarstrom and Zen, 1986; Johnson and Rutherford, 1989; Schmidt, 1992; Anderson and Smith, 1995). Apart from the restricted paragenesis necessary for its successful application, temperature-sensitive substitutions (such as the edenite-forming reaction) and low- $f \mathrm{O}_{2}$ conditions affect Al-in-hornblende and limit its applicability (Anderson and Smith, 1995). The $\mathrm{Fe} /(\mathrm{Fe}+\mathrm{Mg})$ of the Batalha amphiboles exceeds 0.65 , implying that barometry based on Al-in-hornblende may yield excessively high pressures (Anderson and Smith, 1995). However, according to Borodina et al. (1999), $f \mathrm{O}_{2}$ conditions would reflect the total pressure 
(mostly $\mathrm{P}_{\mathrm{H} 2 \mathrm{O}}$ ) during the cooling and oxidation that accompany the evolution of a pluton. Thus, $\mathrm{fO}_{2}$ could represent a pressure-dependent variable and enable tentative barometric calculations.

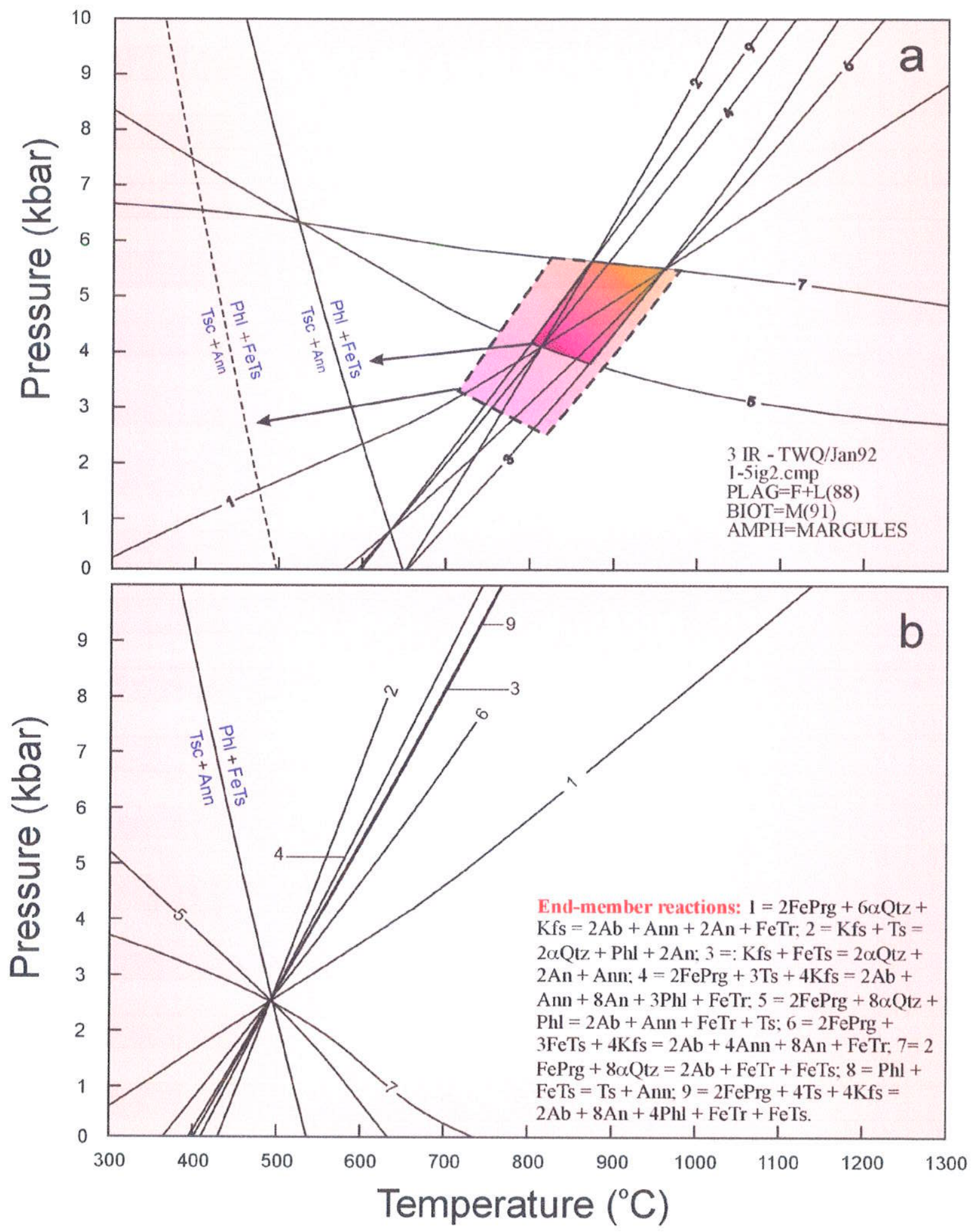

Fig. 14. TWQ thermobarometry for (a) magmatic and (b) hydrothermal mineral assemblages of Batalha. Rectangle with continuous boundary represents the most equilibrated sample and rectangle with dashed boundary covers the field calculated for other samples. Arrows in (a) indicate low-temperature reequilibrium of biotite. Mineral abbreviations after Kretz (1973). End-member activities from Berman (1988), McMullin (1991), Mader and Berman (1992) and Fuhrman and Lindsley (1988).

Table 6 
Estimated P-T conditions of magmatic and hydrothermal stages from the Batalha Granite

\begin{tabular}{|c|c|c|c|c|}
\hline & Temperature $\left({ }^{\circ} \mathrm{C}\right)$ & Pressure (kbar) & Method & Reference \\
\hline $\begin{array}{l}\text { Magmatic mineral } \\
\text { assemblage }\end{array}$ & $955-800$ & $\begin{array}{l}5.6-4.2 \\
3.60 \\
4.18-4.76 \\
3.80-4.07 \\
3.63-4.09^{*}\end{array}$ & $\begin{array}{l}\text { TWQ } \\
\text { Al-in- } \\
\text { hornblende } \\
\text { geobarometer }\end{array}$ & $\begin{array}{l}\text { Berman (1992) } \\
\text { Johnson and Rutherford (1989) } \\
\text { Schmidt (1992) } \\
\text { Hammarstrom and Zen (1986) } \\
\text { Anderson and Smith (1995) }\end{array}$ \\
\hline K-metassomatism & 490 & 2.6 & TWQ & Berman (1992) \\
\hline Propylitization & $495-340$ & & $\begin{array}{l}\text { Chlorite-biotite } \\
\text { geothermometer } \\
\mathrm{Al}^{\mathrm{IV}} \text {-in-chlorite } \\
\text { geothermometer }\end{array}$ & Dickenson and Hewitt (1986) \\
\hline $\begin{array}{l}\text { Sericitization } \\
\text { Shear zone }\end{array}$ & $\begin{array}{l}290-115 \\
292-288\end{array}$ & 1.2 & $\begin{array}{l}\text { TWQ } \\
\mathrm{Al}^{\mathrm{IV}} \text {-in-chlorite } \\
\text { geothermometer }\end{array}$ & $\begin{array}{l}\text { Berman (1992) } \\
\text { Cathelineau and Nieva (1985) }\end{array}$ \\
\hline
\end{tabular}

* Pressure calculated using the equation of Anderson \& Smith (1995) at $850^{\circ} \mathrm{C}$.

The $\mathrm{Fe}^{3+}$ and $\mathrm{Al}^{\mathrm{IV}}$ relationships of the majority of Batalha amphiboles indicate similarity with amphiboles of the mid-level plutons (Fig. 8b). This could reflect crystallization pressures and/or predominant conditions during the post-magmatic stage between 5 and $2 \mathrm{kbar}$ (Borodina et al., 1999). The application of various Al-in-hornblende barometers to most of the Batalha amphibole yields pressures between 4.8 and $3.6 \mathrm{kbar}$ (Table 6). Considering the precision of these methods, the values are quite close and consistent with the P-T conditions estimated independently from TWQ (Fig. 14a). The barometry for the igneous assemblage (Fig. 14a; Table 6) could indicate maximum depth of early magma crystallization, while K-metasomatic assemblage (Fig. 14b) should indicate the depth of consolidation of the Batalha granite.

Crystallization temperatures for the hydrothermal minerals were estimated using the biotite-chlorite pair (cf. Dickenson and Hewitt, 1986) at the TWQ pressure (2.6 kbar) for the K metasomatism stage (Fig. 14b). The equilibrium between hydrothermal biotite and chlorite I was also calculated at different pressures defining univariant reaction curves. The obtained crystallization temperatures range from 495 to $340^{\circ} \mathrm{C}$.

The geothermometer based on the $\mathrm{Al}^{\mathrm{IV}}$ content of chlorite (Cathelineau and Nieva, 1985; Cathelineau, 1988) was applied with some caution, as the chlorite composition depends not only on the temperature, but also on the nature of the coexisting mineral assemblage and bulk rock composition (Caritat et al., 1993). A correction for the $\mathrm{Al}^{\mathrm{IV}}-\mathrm{T}$ dependency using $\mathrm{Fe} /(\mathrm{Fe}+\mathrm{Mg}$ ) in chlorite was adopted as proposed by Kranidiotis and MacLean (1987), Jowett (1991) and Zang and Fyfe (1995). The temperature obtained from the equation of Cathelineau and Nieva (1985), vary from 358 to $326^{\circ} \mathrm{C}$ for chlorite I and 292 to $288^{\circ} \mathrm{C}$ for chlorite II.

The $\mathrm{P}-\mathrm{T}$ conditions of the late paragenesis sericite + hydrothermal albite $+\mathrm{K}$-feldspar + quartz were also estimated using the TWQ. The core compositions of the minerals show strong 
chemical disequilibria and indicate temperatures between 290 and $115^{\circ} \mathrm{C}$. The rim compositions show equilibrium around $288{ }^{\circ} \mathrm{C}$ at $1.2 \mathrm{kbar}$ for the reactions quartz + kaolinite $=$ pyrophyllite + $\mathrm{H}_{2} \mathrm{O}$ and albite + muscovite $=$ microcline + paragonite. These mineral assemblages indicate reequilibration at temperatures around $150-65^{\circ} \mathrm{C}$. These results are coherent with the petrographic observations that early muscovite crystallized at the final stage of the evolution of the hydrothermal fluid. The lower temperatures may be related to shear zones.

\section{Whole-rock geochemistry}

\subsection{Least-altered rocks}

The least-altered granites of Batalha are transitional between calc-alkaline and subalkaline and metaluminous and peraluminous (Fig. 15a, b; Table 7). The $\mathrm{Ga} / \mathrm{Al}$ versus agpaitic index plot (Fig. 15c) shows a trend from the field of fractionated I- and S-type granites to the Atype granite field. The $\mathrm{Nb} / \mathrm{Y}$ ratios are relatively low and the studied granites plot in the A2subtype of the A-type granites (Eby, 1992). In spite of the small compositional variation in the least-altered rocks, the $\mathrm{Rb}, \mathrm{Sr}$ and $\mathrm{Ba}$ contents (Table 7) suggest that plagioclase and hornblende fractionation was important in the evolution of the Batalha granite.

In the $\mathrm{Rb}$ versus $\mathrm{Y}+\mathrm{Nb}$ diagram of Pearce et al. (1984), the least-altered Batalha granites plot on the boundary between the volcanic arc and within plate granite fields (Fig. 15d). The high $\mathrm{Rb}$ concentrations could be explained by introduction of the element into the mantle through a subduction zone, strong fluid influx during magmatic crystallization, or extensive crustal contamination owing to lower crustal or upper mantle melting in post-collisional relaxation regimes (see Pearce et al., 1984). Rb-Hf-Ta values of the Batalha granite point to late- and post-collisional signatures (cf. Harris et al., 1986).

The Batalha granite shows a LREE-enriched REE pattern (Fig. 16a; Table 7). The $\Sigma$ LREE (206.21 to 313.13), $\Sigma$ HREE (23.64 to 33.16), $(\mathrm{Gd} / \mathrm{Lu})_{\mathrm{N}}(1.19$ to 1.60$),(\mathrm{La} / \mathrm{Lu})_{\mathrm{N}}(6.99$ to 13.35), $(\mathrm{La} / \mathrm{Yb})_{\mathrm{N}}(7.14$ to 13.33$)$ and negative Eu anomaly $\left(\mathrm{Eu} / \mathrm{Eu}^{*}=0.29\right.$ to 0.40$)$ indicate differences in comparison to the typical aluminous A-type granites (Rämö and Haapala, 1995, Dall'Agnol et al., 1999). These characteristics probably reflect the calc-alkaline nature of the Batalha granite. 
Whole-rock geochemical data for Batalha Granite

\begin{tabular}{|c|c|c|c|c|c|c|c|c|c|c|c|c|c|c|c|c|c|c|c|c|c|c|c|}
\hline & \multicolumn{5}{|c|}{ (1) } & \multicolumn{6}{|c|}{2} & \multicolumn{4}{|c|}{3} & \multicolumn{3}{|l|}{4} & \multirow{2}{*}{$\frac{6}{\mathrm{Fbt}-2 / 10}$} & \multirow{2}{*}{$\frac{7}{\text { Fbt-5/3b }}$} & \multirow{2}{*}{$\frac{8}{F b t-5 / 3 a}$} & \multicolumn{2}{|l|}{9} \\
\hline & $\mathrm{Fbt}-5 / 2$ & Fbt-1/5 & $\mathrm{Fbt}-4 / 2$ & $\mathrm{Fbt}-4 / 3$ & $\mathrm{Fbt}-2 / 3$ & $\mathrm{Fbt}-2 / 7 \mathrm{a}$ & Fbt-1/3 & $\mathrm{Fbt}-2 / 4$ & Fbt-1/7 & $\mathrm{Fbt}-3 / 10$ & Fbt-3/9 & Fbt-3/1 & $\mathrm{Fbt}-3 / 7 \mathrm{a}$ & $\mathrm{Fbt}-4 / 5$ & Fbt-1/2 & $\mathrm{Fbt}-3 / 2$ & Fbt-3/5 & $\mathrm{Fbt}-3 / 7 \mathrm{~b}$ & & & & $\mathrm{Fbt}-2 / 7 \mathrm{~b}$ & $\mathrm{Fbt}-3 / 3$ \\
\hline $\mathrm{SiO}_{2}$ & 71.88 & 72.13 & 71.50 & 71.92 & 72.13 & 71.31 & 73.19 & 72.49 & 73.93 & 72.22 & 72.66 & 74.40 & 73.76 & 72.59 & 72.69 & 59.69 & 62.01 & 68.04 & 70.54 & 70.39 & 70.46 & 66.34 & 57.01 \\
\hline $\mathrm{TiO}_{2}$ & 0.19 & 0.18 & 0.21 & 0.19 & 0.20 & 0.19 & 0.16 & 0.20 & 0.20 & 0.19 & 0.19 & 0.18 & 0.17 & 0.16 & 0.15 & 0.21 & 0.24 & 0.21 & 0.19 & 0.24 & 0.21 & 0.21 & 0.18 \\
\hline $\mathrm{Al}_{2} \mathrm{O}_{3}$ & 13.73 & 13.67 & 13.59 & 13.34 & 13.27 & 13.66 & 12.73 & 13.14 & 13.05 & 13.68 & 13.70 & 12.76 & 12.69 & 13.47 & 12.94 & 17.10 & 17.22 & 11.87 & 13.49 & 15.01 & 14.10 & 17.44 & 19.84 \\
\hline $\mathrm{Fe}_{2} \mathrm{O}_{3} \mathrm{~T}$ & 2.18 & 2.12 & 2.47 & 2.23 & 2.35 & 2.34 & 1.95 & 2.43 & 2.10 & 2.24 & 2.12 & 2.07 & 1.90 & 1.98 & 2.12 & 7.05 & 5.43 & 7.55 & 2.50 & 2.55 & 2.31 & 2.75 & 6.76 \\
\hline $\mathrm{MnO}$ & 0.04 & 0.05 & 0.05 & 0.05 & 0.05 & 0.04 & 0.05 & 0.06 & 0.04 & 0.04 & 0.05 & 0.02 & 0.03 & 0.01 & 0.02 & 0.05 & 0.02 & 0.03 & 0.02 & 0.02 & 0.02 & 0.02 & 0.07 \\
\hline $\mathrm{MgO}$ & 0.29 & 0.29 & 0.36 & 0.31 & 0.37 & 0.42 & 0.18 & 0.47 & 0.37 & 0.40 & 0.34 & 0.65 & 0.35 & 0.25 & 0.16 & 3.76 & 0.46 & 0.50 & 0.47 & 0.35 & 0.40 & 0.34 & 4.22 \\
\hline $\mathrm{CaO}$ & 1.42 & 1.43 & 1.29 & 1.25 & 1.13 & 1.16 & 0.99 & 1.07 & 1.06 & 1.02 & 1.07 & 0.67 & 0.66 & 0.63 & 0.39 & 0.10 & 0.26 & 0.21 & 1.22 & 0.23 & 0.23 & 1.41 & 0.17 \\
\hline $\mathrm{Na}_{2} \mathrm{O}$ & 3.62 & 3.66 & 3.60 & 3.51 & 3.74 & 4.23 & 3.63 & 3.78 & 3.47 & 3.54 & 3.47 & 3.52 & 3.55 & 3.65 & 3.41 & 4.67 & 0.33 & 0.13 & 1.95 & 7.78 & 1.18 & 9.51 & 8.41 \\
\hline $\mathrm{K}_{2} \mathrm{O}$ & 4.90 & 5.16 & 4.75 & 4.92 & 4.39 & 4.42 & 4.60 & 4.65 & 4.78 & 5.32 & 5.35 & 4.74 & 4.65 & 5.37 & 5.48 & 3.99 & 10.13 & 4.23 & 6.47 & 1.00 & 10.14 & 0.07 & 0.12 \\
\hline $\mathrm{P}_{2} \mathrm{O}_{5}$ & 0.05 & 0.04 & 0.05 & 0.05 & 0.04 & 0.04 & 0.03 & 0.05 & 0.04 & 0.04 & 0.04 & 0.04 & 0.04 & 0.04 & 0.03 & 0.03 & 0.05 & 0.04 & 0.06 & 0.03 & 0.05 & 0.04 & 0.04 \\
\hline LOI & 0.94 & 1.46 & 1.05 & 0.98 & 1.21 & 1.80 & 1.05 & 2.12 & 1.27 & 1.36 & 1.09 & 1.45 & 1.54 & 1.21 & 1.47 & 2.85 & 2.61 & 6.15 & 2.63 & 1.33 & 1.37 & 1.69 & 3.23 \\
\hline Total & 99.25 & 100.19 & 98.92 & 98.75 & 98.88 & 99.61 & 98.55 & 100.46 & 100.31 & 100.05 & 100.08 & 100.50 & 99.34 & 99.36 & 98.86 & 99.50 & 98.76 & 98.96 & 99.54 & 98.93 & 100.48 & 99.83 & 100.04 \\
\hline $\mathrm{Ba}$ & 693 & 586 & 735 & 597 & 503 & 568 & 392 & 410 & 464 & 595 & 603 & 488 & 577 & 624 & 432 & 280 & 758 & 412 & 852 & 135 & 1530 & 38 & 26 \\
\hline $\mathrm{Rb}$ & 203 & 188 & 198 & 245 & 210 & 178 & 213 & 201 & 179 & 235 & 239 & 159 & 201 & 235 & 214 & 131 & 398 & 227 & 277 & 31 & 368 & 6 & 6 \\
\hline $\mathrm{Sr}$ & 91 & 82 & 88 & 84 & 78 & 63 & 52 & 64 & 67 & 72 & 74 & 49 & 42 & 55 & 38 & 37 & 44 & 6 & 56 & 17 & 39 & 37 & 45 \\
\hline $\mathrm{Ga}$ & 17 & 17 & 19 & 2 & 19 & 19 & 19 & 17 & 16 & 19 & 19 & 15 & 17 & 19 & 18 & 35 & 38 & 36 & 21 & 22 & 15 & 25 & 32 \\
\hline Y & 40 & 39 & 43 & 52 & 47 & 36 & 54 & 44 & 39 & 45 & 47 & 23 & 35 & 44 & 51 & 18 & 39 & 26 & 46 & 45 & 61 & 44 & 22 \\
\hline $\mathrm{Zr}$ & 266 & 231 & 281 & 288 & 242 & 227 & 252 & 288 & 274 & 262 & 271 & 257 & 239 & 244 & 224 & 301 & 301 & 222 & 238 & 297 & 275 & 287 & 252 \\
\hline $\mathrm{Nb}$ & 13 & 13 & 14 & 16 & 16 & 14 & 16 & 15 & 14 & 15 & 15 & 12 & 14 & 14 & 15 & 16 & 19 & 15 & 15 & 17 & 14 & 16 & 13 \\
\hline Cs & 4.1 & 4.3 & 5.2 & 5.1 & 3.6 & 1.8 & 4.5 & 3.3 & 3.4 & 3.6 & 3.7 & 1.7 & 2.2 & 3.1 & 2.2 & 1.4 & 4.2 & 2.8 & 4.1 & 0.4 & 2.7 & 0.4 & 0.4 \\
\hline $\mathrm{Sc}$ & 4 & 4 & 4 & 4 & 4 & 4 & 2 & 4 & 3 & 4 & 3 & 3 & 3 & 3 & 3 & 5 & 5 & 3 & 4 & 4 & 4 & 4 & 4 \\
\hline $\mathrm{Cu}$ & 9 & 9 & 11 & 9 & 9 & 42 & 9 & 11 & 9 & 13 & 9 & 47 & 131 & 75 & 60 & 9 & 142 & 115 & 177 & 122 & 89 & 204 & 9 \\
\hline $\mathrm{Zn}$ & 29 & 46 & 50 & 47 & 81 & 36 & 54 & 96 & 398 & 29 & 36 & 29 & 29 & 54 & 29 & 37 & 140 & 29 & 29 & 1960 & 29 & 45 & 29 \\
\hline $\mathrm{Hf}$ & 7.5 & 6.5 & 7.8 & 8.7 & 7.4 & 6.6 & 8.0 & 8.5 & 7.3 & 7.6 & 7.7 & 7.3 & 7.1 & 7.5 & 7.4 & 9.4 & 8.7 & 6.3 & 7.2 & 8.3 & 8.0 & 8.2 & 7.4 \\
\hline $\mathrm{Ta}$ & 2.7 & 2.9 & 3.3 & 3.5 & 3.8 & 3.3 & 4.4 & 3.3 & 2.0 & 3.3 & 3.9 & 3.0 & 3.9 & 3.2 & 4.2 & 2.4 & 2.1 & 3.3 & 3.7 & 3.4 & 4.3 & 2.4 & 1.7 \\
\hline $\mathrm{Tl}$ & 0.9 & 0.6 & 1.0 & 1.0 & 1.0 & 1.0 & 1.0 & 0.9 & 0.5 & 1.1 & 1.0 & 1.0 & 1.1 & 1.4 & 1.0 & 0.7 & 1.1 & 0.6 & 1.3 & 0.2 & 2.0 & 0.2 & 0.1 \\
\hline $\mathrm{Pb}$ & 23 & 20 & 23 & 24 & 25 & 13 & 25 & 33 & 180 & 21 & 22 & 10 & 17 & 26 & 16 & 7 & 38 & 6 & 13 & 464 & 66 & 22 & 4 \\
\hline Th & 21.5 & 17.8 & 21.9 & 26.6 & 26.0 & 21.6 & 29.0 & 22.1 & 19.5 & 24.4 & 23.4 & 22.8 & 23.8 & 22.5 & 23.2 & 28.8 & 20.6 & 19.0 & 25.8 & 21.2 & 24.4 & 25.2 & 22.7 \\
\hline $\mathrm{U}$ & 5.7 & 4.8 & 4.9 & 7.2 & 7.6 & 5.9 & 8.3 & 6.4 & 4.5 & 7.0 & 7.4 & 5.5 & 7.0 & 6.4 & 6.7 & 10.2 & 5.4 & 6.0 & 7.2 & 6.1 & 6.8 & 6.8 & 6.3 \\
\hline $\mathrm{La}$ & 51.9 & 48.9 & 77.1 & 77.6 & 49.8 & 54.4 & 57.9 & 43.5 & 51.1 & 54.2 & 51.3 & 15.7 & 40.9 & 40.7 & 52.4 & 13.7 & 62.7 & 51.9 & 54.6 & 71.3 & 26.4 & 47.7 & 10.5 \\
\hline $\mathrm{Ce}$ & 101.0 & 99.5 & 143.0 & 145.0 & & 102.0 & 113.0 & 90.1 & 103.0 & 105.0 & 101.0 & 32.7 & 77.8 & 80.5 & 101.0 & 29.5 & 122.0 & 93.8 & 105.0 & 135.0 & 51.2 & 93.8 & 21.9 \\
\hline PT & 11.6 & 10.7 & 15.7 & 16.3 & 11.1 & 11.4 & 12.7 & 9.8 & 11.3 & 12.1 & 11.4 & 3.6 & 8.9 & 9.3 & 11.5 & 3.3 & 13.8 & 10.9 & 12.2 & 14.9 & 6.0 & 10.7 & 2.7 \\
\hline $\mathrm{Nd}$ & 45.3 & 39.1 & 61.1 & 62.6 & 44.2 & 43.6 & 50.1 & 36.8 & 41.8 & 46.7 & 44.6 & 13.9 & 35.9 & 36.1 & 46.2 & 12.1 & 54.0 & 45.9 & 47.9 & 59.4 & 25.1 & 42.1 & 11.4 \\
\hline $\mathrm{Sm}$ & 8.3 & 7.2 & 10.2 & 10.7 & 8.6 & 7.6 & 9.7 & 7.1 & 7.5 & 8.5 & 8.4 & 2.5 & 6.8 & 7.1 & 9.0 & 2.2 & 9.4 & 7.9 & 8.6 & 11.0 & 6.1 & 7.7 & 3.3 \\
\hline $\mathrm{Eu}$ & 0.93 & 0.86 & 1.01 & 0.93 & 0.79 & 0.81 & 0.79 & 0.72 & 0.80 & 0.82 & 0.83 & 0.25 & 0.72 & 0.71 & 0.75 & 0.25 & 0.64 & 0.50 & 0.80 & 1.17 & 0.75 & 0.71 & 0.36 \\
\hline $\mathrm{Gd}$ & 7.00 & 6.09 & 7.90 & 9.00 & 7.10 & 6.00 & 8.00 & 6.07 & 6.50 & 7.60 & 7.10 & 2.20 & 6.00 & 6.60 & 7.60 & 2.00 & 7.80 & 6.20 & 7.40 & 8.60 & 7.20 & 6.60 & 3.20 \\
\hline $\mathrm{Tb}$ & 1.2 & 1.1 & 1.3 & 1.4 & 1.2 & 1.0 & 1.4 & 1.2 & 1.1 & 1.2 & 1.2 & 0.5 & 1.0 & 1.1 & 1.3 & 0.4 & 1.2 & 0.7 & 1.2 & 1.4 & 1.5 & 1.2 & 0.6 \\
\hline Dy & 7.0 & 6.4 & 7.5 & 8.7 & 7.8 & 6.0 & 9.0 & 7.4 & 6.8 & 7.5 & 7.7 & 3.4 & 5.9 & 7.3 & 8.6 & 3.4 & 7.1 & 4.2 & 7.5 & 8.1 & 10.1 & 7.3 & 4.4 \\
\hline Ho & 1.4 & 1.3 & 1.5 & 1.8 & 1.6 & 1.2 & 1.9 & 1.5 & 1.3 & 1.6 & 1.6 & 0.8 & 1.2 & 1.6 & 1.8 & 0.8 & 1.5 & 0.9 & 1.6 & 1.6 & 2.1 & 1.5 & 0.9 \\
\hline Er & 4.3 & 3.8 & 4.5 & 5.5 & 4.8 & 3.8 & 5.7 & 4.6 & 3.9 & 4.8 & 4.9 & 2.6 & 3.9 & 4.6 & 5.4 & 2.6 & 4.3 & 3.0 & 4.7 & 4.7 & 6.4 & 4.5 & 3.1 \\
\hline $\mathrm{Tm}$ & 0.64 & 0.58 & 0.68 & 0.84 & 0.76 & 0.58 & 0.90 & 0.71 & 0.58 & 0.74 & 0.77 & 0.44 & 0.62 & 0.73 & 0.85 & 0.45 & 0.70 & 0.51 & 0.71 & 0.76 & 0.99 & 0.69 & 0.51 \\
\hline $\mathrm{Yb}$ & 3.9 & 3.9 & 3.9 & 5.1 & 4.7 & 3.5 & 5.3 & 4.7 & 3.8 & 4.5 & 4.9 & 2.8 & 3.9 & 4.5 & 5.0 & 2.9 & 4.3 & 3.4 & 4.3 & 4.6 & 5.8 & 4.1 & 3.3 \\
\hline $\mathrm{Lu}$ & 0.62 & 0.57 & 0.60 & 0.82 & 0.74 & 0.58 & 0.84 & 0.74 & 0.58 & 0.72 & 0.76 & 0.47 & 0.63 & 0.73 & 0.79 & 0.48 & 0.69 & 0.55 & 0.67 & 0.70 & 0.82 & 0.67 & 0.54 \\
\hline
\end{tabular}

Key to rock types: (1) Least-altered granitoid; (2) Na- and K-altered samples; (3) Na- and K-altered and propylitized samples; (4) Na- and K-altered and strongly propylitized sample; (5) Na- and K-altered, propylitized, and sericitized samples; (6) Na-altered, K-altered, propylitized, sericitized and carbonatized sample; (7) Na-altered sample; (8) Naaltered and $\mathrm{K}$-altered sample; (9) Na-altered and propylitized samples. Oxides are in $\%$ and minor elements in ppm. 

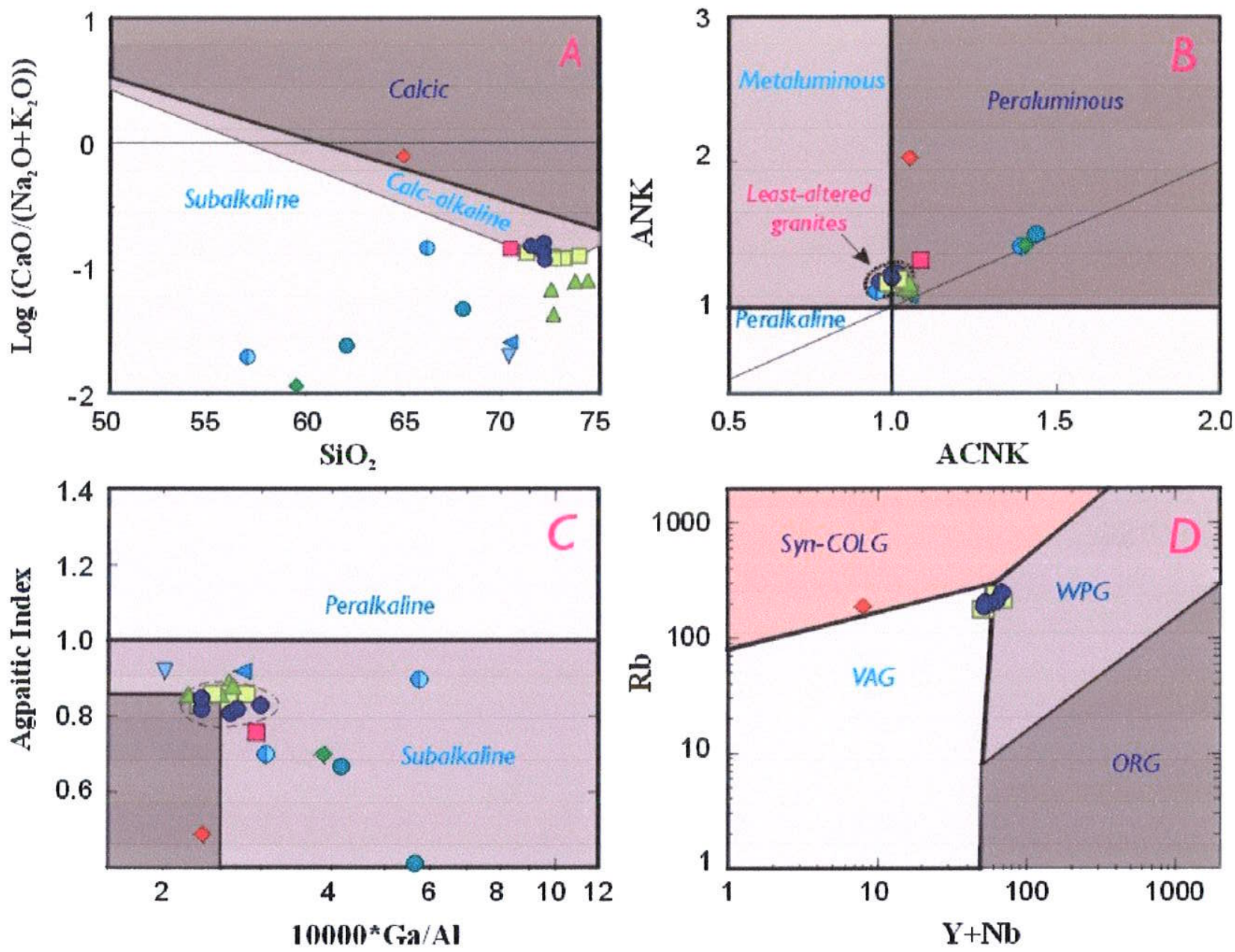

Fig. 15. Composition of Batalha granite in (a) the lime-alkali index diagram (Brown, 1982); (b) ACNK versus ANK diagram (Maniar and Piccoli, 1989); (c) Ga/Al versus agpaitic index diagram (Whalen et al., 1987); and (d) Rb versus $\mathrm{Y}+\mathrm{Nb}$ diagram (Pearce et al., 1984). ACNK is molecular $\mathrm{Al}_{2} \mathrm{O}_{3} /\left(\mathrm{CaO}+\mathrm{Na}_{2} \mathrm{O}\right.$ $\left.+\mathrm{K}_{2} \mathrm{O}\right)$, ANK molecular $\mathrm{Al}_{2} \mathrm{O}_{3}\left(\mathrm{Na}_{2} \mathrm{O}+\mathrm{K}_{2} \mathrm{O}\right)$. Abbreviations in (d) denote ocean ridge granites (ORG), volcanic arc granites (VAG), within plate granites (WPG), and syn-collisional granites (syn-COLG). Symbols as in Fig. 5.

\subsection{Altered rocks}

For the purpose of analyzing the chemical changes of the hydrothermal alteration that affected the Batalha granite, defined by $\mathrm{Na}$ and $\mathrm{K}$ alteration, propylitization, sericitization and carbonatization, two groups of rocks were distinguished. Group I is characterized by early strong Na metasomatism (Fig. 17a), Group II by initial weak Na metasomatism (Fig. 17b). The strong Na-altered granites (Group I) show intense Ca and $\mathrm{K}$ removal in relation to least-altered granites (Fig. 17a; path 1), followed by strong $\mathrm{K}$ reintroduction with $\mathrm{K}$-feldspar crystallization in welldefined fronts in the granite (Fig. 3b) resulting in path 2 (Fig. 17a). The Na-altered granites without significant $\mathrm{K}$ alteration were propylitized along path 3 (Fig. 17a); this caused loss of $\mathrm{K}$ and Ca, similar to that reported by Dall'Agnol (1980) for hydrothermally altered granites from the Amazonian craton. 


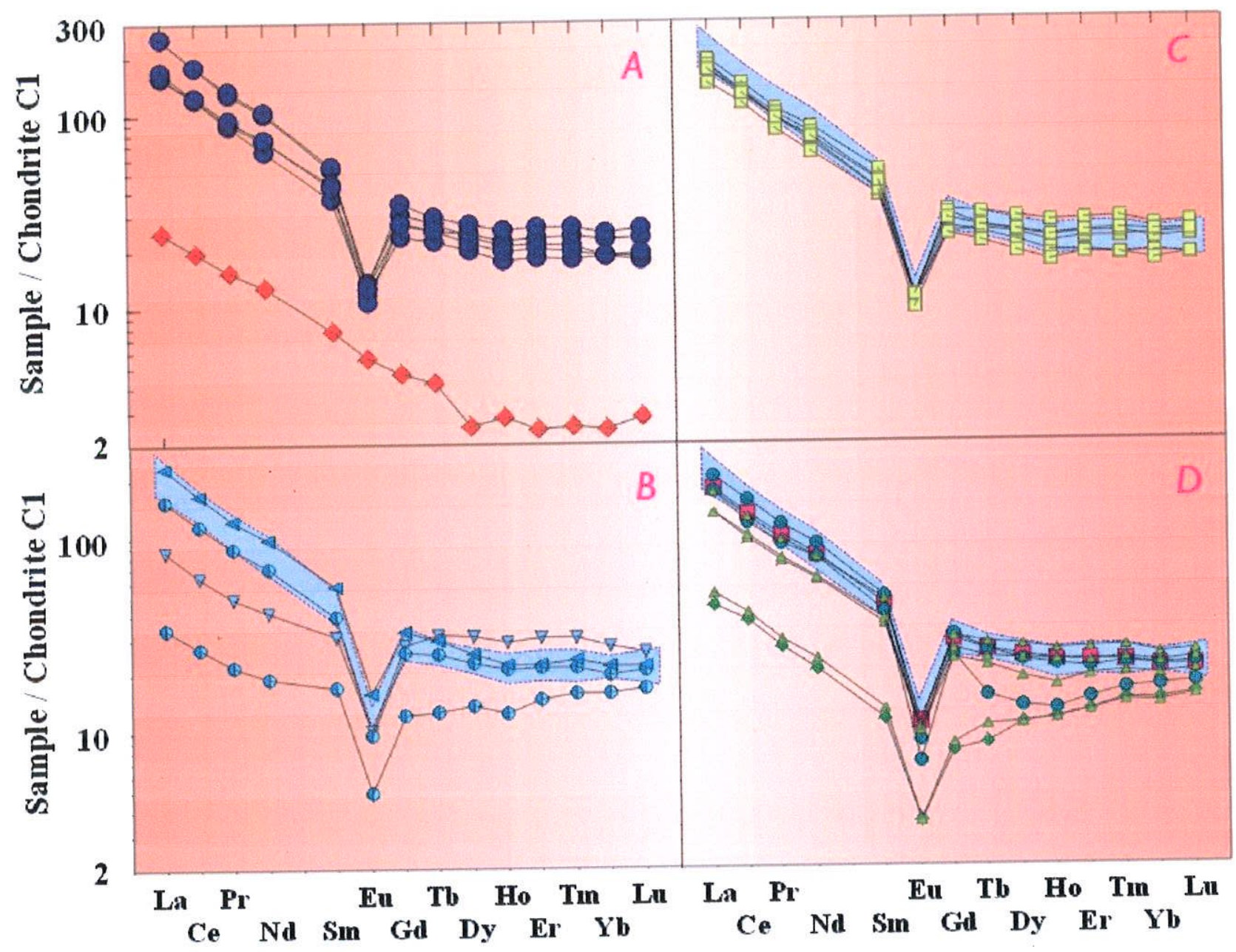

Fig. 16. Chondrite-normalized rare earth element (REE) patterns (Boynton, 1984) for (a) the leastaltered granites; (b) granites with strong early Na alteration; (c) K-altered granites; and (d) propylitized, sericitized and carbonatized granites with weak early Na alteration. The dashed field in (b), (c) and (d) represents REE variation for the least-altered granites.

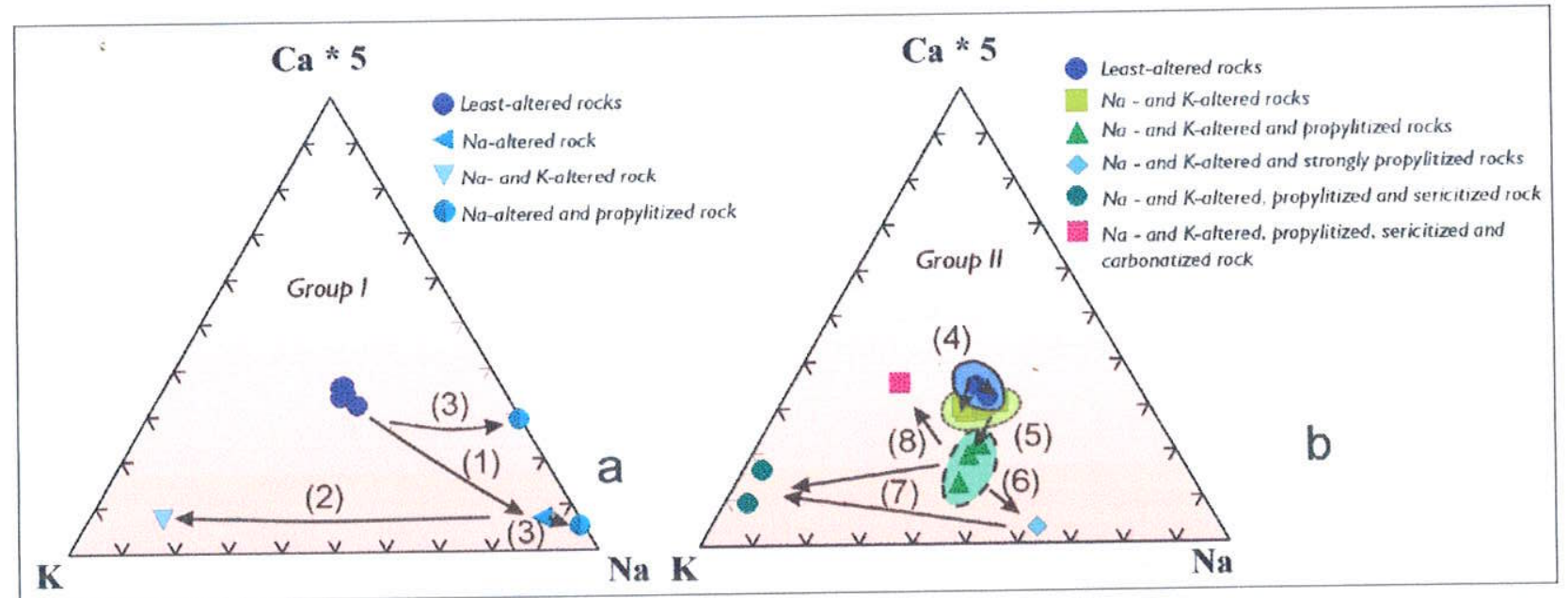

Fig. 17. Ca*5-K-Na cationic diagram showing hydrothermal alteration trends for (a) Group I Naaltered granites $(1=$ Na alteration; $2=K$ alteration; $3=$ propylitization $)$ and $(b) K$-altered granites $(4=$ $\mathrm{Na}$ and $\mathrm{K}$ alteration; $5=$ propylitization; $6=$ intense propylitization; $7=$ sericitization trend; $8=$ carbonatization) for Batalha. 
Compared to the least-altered granites, the Group II granites present a loss of $\mathrm{Ca}$, accompanied by slight $\mathrm{K}$ or $\mathrm{Na}$ enrichments (Fig. 17b, path 4) during $\mathrm{Na}$ and $\mathrm{K}$ metasomatism. The pervasive to initial fissural propylitization caused a more intense decalcification and a slight enrichment in K (Fig. 17b, path 5), represented by biotite and subordinate sericite. In rocks where the propylitization was more intense, a strong reduction in $\mathrm{Ca}$ and increase in $\mathrm{Na}$ is observed (Fig. 17b, path 6). The late overprinting of sericitic alteration resulted in strong $\mathrm{Na}$ and Ca losses and enrichment in K (Fig. 17b, path 7). Path 8 in Fig. 17b represents overprint of carbonatization after the sericitization.

Mass balance between unaltered and altered rocks was calculated in relation to the average composition of the least-altered granites (Fig. 18), considering $\mathrm{Nb}$ as a relatively immobile element. The Na metasomatism (Fig. 18a, b) in Group I rocks is mainly accompanied by strong enrichment in $\mathrm{Na}(80 \%), \mathrm{Cu}$ (up to 995\%), $\mathrm{Zn} \mathrm{(1370 \% )} \mathrm{and} \mathrm{Pb}(1600 \%)$, significant losses in $\mathrm{Ca}(85 \%), \mathrm{K}(82 \%), \mathrm{Mn}, \mathrm{P}, \mathrm{Rb}, \mathrm{Ba}$ and $\mathrm{Sr}$, and slight losses in Si, Y, Ta, Th, U. The overprint of the strong $\mathrm{K}$ metasomatism, relative to the previous strong $\mathrm{Na}$ alteration, essentially causes gains of $\mathrm{K}(115 \%), \mathrm{P}, \mathrm{Ba}, \mathrm{Rb}, \mathrm{Sr}, \mathrm{Y}, \mathrm{Cu}, \mathrm{Ta}$, Th, $\mathrm{U}$, small gains in $\mathrm{Mg}$ and $\mathrm{Si}$, and losses in $\mathrm{Na}(66 \%)$, the LREE, $\mathrm{Zn}$ and $\mathrm{Ga}$. The late propylitization caused strong $\mathrm{Mg}, \mathrm{Na}, \mathrm{Fe}^{3+}$ tot, $\mathrm{Mn}$, $\mathrm{Ca}, \mathrm{Al}, \mathrm{P}$ and $\mathrm{Ga}$ enrichments and losses in $\mathrm{K}, \mathrm{Ba}, \mathrm{Rb}, \mathrm{Y}, \mathrm{Cu}, \mathrm{Zn}, \mathrm{Ta}, \mathrm{Pb}$, the LREE (Fig. 18a, b). $\mathrm{Zr}, \mathrm{Sc}$ and $\mathrm{Ti}$ are relatively immobile in all cases.

The rocks affected by weak early $\mathrm{Na}$ metasomatism and weak to moderate $\mathrm{K}$ metasomatism (Group II) are characterized by $\mathrm{Cu}$ (up to $1330 \%$ ), $\mathrm{Zn}$ (up to $710 \%$ ) and $\mathrm{Pb}$ (up to $700 \%$ ) enrichments accompanied by $\mathrm{Ca}, \mathrm{P}, \mathrm{Ba}, \mathrm{Sr}$, Sc and LREE losses (Fig. 18c, d). Different samples may present small gains or losses of $\mathrm{K}$ due to initial $\mathrm{K}$ removal during $\mathrm{Na}$ alteration followed by $\mathrm{K}$ reintroduction during $\mathrm{K}$ alteration. The overprint of the initial propylitization relative to the $\mathrm{Na}$ and $\mathrm{K}$ alterations mainly promotes $\mathrm{Mg}$ and $\mathrm{K}$ gains and losses of $\mathrm{Ca}$ (up to $70 \%$ ), Mn, Sr, $\mathrm{Zn}, \mathrm{Pb}$ and the LREE (Fig. 18c, d). In rocks where the propylitization was more intense, there are relative increases in $\mathrm{Fe}^{3+}$ tot, $\mathrm{Mg}, \mathrm{Na}$, $\mathrm{Ga}$ and $\mathrm{U}$ and reductions in $\mathrm{Ca}(93 \%)$, $\mathrm{Ba}, \mathrm{Rb}, \mathrm{Y}, \mathrm{Cu}, \mathrm{Pb}, \mathrm{Ta}, \mathrm{Si}, \mathrm{K}, \mathrm{P}, \mathrm{Sr}, \mathrm{Zn}$ and the LREE. The overprint of the sericitic alteration results in relative enrichment in $\mathrm{K}, \mathrm{P}, \mathrm{Cu}$ (up to $1070 \%$ ), $\mathrm{Rb}, \mathrm{Ba}, \mathrm{Y}$, the LREE and $\mathrm{Zn}$ and impoverishment in $\mathrm{Na}$ (up to $96 \%$ ), $\mathrm{Mn}, \mathrm{Fe}^{3+}$ tot, $\mathrm{Sr}$, Th and $\mathrm{U}$ (Fig. 18c, d). The carbonatization after sericitization is mainly characterized by gains in $\mathrm{Si}, \mathrm{Ca}, \mathrm{Na}, \mathrm{P}, \mathrm{Ba}, \mathrm{Sr}, \mathrm{Y}, \mathrm{U}, \mathrm{Ta}, \mathrm{Th}$, the LREE and $\mathrm{Cu}$ (up to 1700\%) and losses in $\mathrm{Fe}^{3+}$ tot, $\mathrm{Ga}$ and $\mathrm{Zn}$. Variations in the relatively immobile elements, such as $\mathrm{Y}, \mathrm{Zr}$ and $\mathrm{Ti}$, may be related to the action of $\mathrm{CO}_{2}-\mathrm{F}$-rich fluids, as described by Hynes (1980), or to rock volume variations.

It is worth noting that in the more intensively altered samples the $\mathrm{Nb}$ is also relatively mobile, resulting in over- or underestimated gains or losses of certain elements (e.g., sample Fbt- 
$3 / 5$ shows a $\mathrm{K}$ gain of $\sim 58 \%$ if $\mathrm{Nb}$ is considered relatively immobile and $110 \%$ if $\mathrm{Yb}$ ).

The strongly Na-altered rocks show a similar REE pattern as the least-altered granites (Fig. 16b). The overprinting of $\mathrm{K}$ metasomatism in these rocks results in a decrease in the LREE and increase in the HREE (Fig. 16b). The K-altered granites with weak early Na metasomatism behave in the same way as the least-altered rocks with a decrease in the LREE and a slight increase in the negative Eu anomaly (Fig. 16c).

The propylitization which affects both Na-altered (Fig. 16b) and K-altered rocks (Fig. 16d) involved gradational reduction in $\mathrm{REE}$, more pronounced for the LREE, proportional to alteration intensity. This is due to gradual destruction of allanite and dissolution of the REE, with partitioning of the HREE into the mafic mineral assemblage. Sericitization and carbonatization provided reintroduction of the REE up to the level observed in the least-altered rocks (Fig. 16d). However, one sericitized sample has lower HREE contents than the least-altered granites.
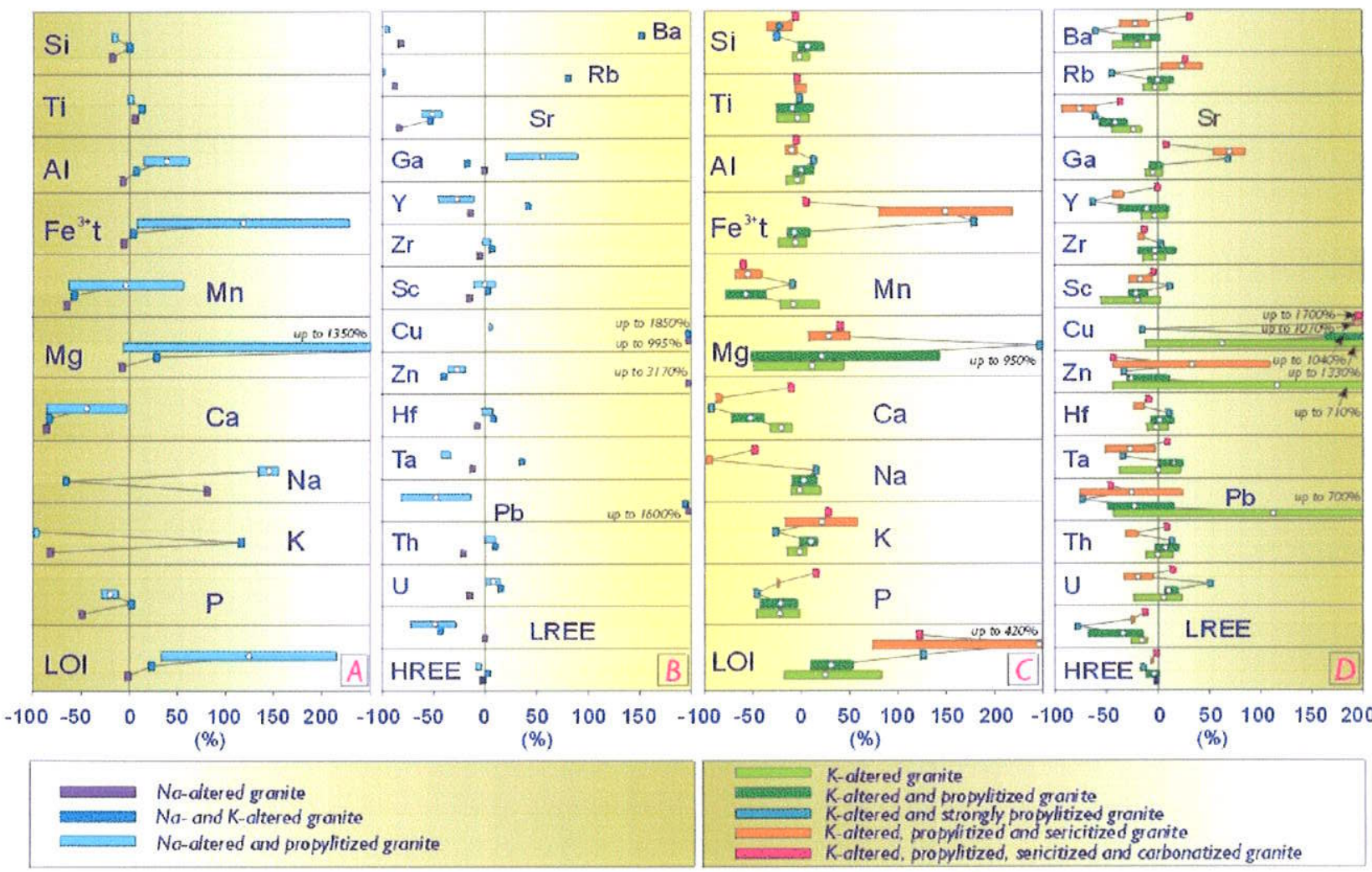

Fig. 18. Isovolumetric cationic mass balance of Batalha granites considering $\mathrm{Nb}$ as a relatively immobile element and using the average composition of the least-altered granites for comparison. Group I denotes granites affected by strong early Na alteration ( $a$ and b), Group II granites affected by early weak Na alteration ( $c$ and d). Horizontal bars correspond to mass balance ranges of various samples of the same alteration style. Lines bind average compositions and indicate the evolutionary sequence of alteration. Based on methods outlined by Gresens (1967), Grant (1986) and Potdevin and Marquer (1987). 


\section{Discussion and concluding remarks}

\subsection{Magmatic system}

The lack of primary magnetite and presence of amphibole with low $\mathrm{Fe}^{3+} /\left(\mathrm{Fe}^{3+}+\mathrm{Fe}^{2+}\right)$ suggest similarity with I-type ilmenite series granitoids (Ishihara, 1981) for the Batalha granite. Relatively more oxidized conditions of the granite crystallization are indicated by the $\mathrm{Fe}^{2+}-\mathrm{Fe}^{3+}-\mathrm{Mg}$ content in the magmatic biotite that plots close to the NNO buffer (Fig. 10), which defines the boundary between the magnetite- and ilmenite-series granitoids. $\mathrm{Fe}^{3+} /\left(\mathrm{Fe}^{3+}+\right.$ $\mathrm{Fe}^{2+}$ ) ratios of magmatic biotite are similar to those observed in hydrothermal biotite (Fig. 10), suggesting that the increase in the oxidation state of magmatic biotite could reflect in situ oxidation of $\mathrm{Fe}^{2+}$ (see Wones and Eugster, 1965).

The absence of magmatic and hydrothermal magnetite in the Batalha granite may be related to high $\mathrm{P}_{\mathrm{H} 2 \mathrm{O}}$. The latter expands the stability fields of hornblende and biotite and precludes precipitation of magnetite in an oxidizing environment (Fershtater et al., 1978). Conditions of relatively high $\mathrm{P}_{\mathrm{H} 2 \mathrm{O}}$ are expected in mesozonal granitic rocks equilibrated at 5-2 kbar (Borodina et al., 1999). This seems also to have been the case for the Batalha granite that crystallized at 5.6-2.6 kbar.

\subsection{Hydrothermal system}

Epithermal systems in the Tapajós Gold Province have been associated with quartzalunite high-sulphidation systems in volcanic rocks of the Iriri Group (Jacobi, 1999; Juliani et al., 2000; Nunes et al., 2000) and adularia-bearing low-sulphidation systems in basic rocks of the Ingarana suite (Dreher et al., 1998). Mesothermal granite-hosted hydrothermal gold systems are associated with $\mathrm{Cu}-\mathrm{Au}$ porphyry (Coutinho et al., 1997; Jacobi, 1999), orogenic lode-gold (Goldfarb et al., 2001) and intrusion-related gold systems (Santos et al., 2001). All these granitehosted deposits seem to share many characteristics (Lang and Baker, 2001), implying that the distinction among these genetic models may not be simple.

Extensive early $\mathrm{Na}$ metasomatism followed by $\mathrm{K}$ metasomatism, propylitization and sericitization related to a post-magmatic hydrothermal system affected the Batalha granite. Gold mineralization was associated with the hydrothermal system, especially with sericitization. Basemetal enrichments were linked to $\mathrm{Na}$ and $\mathrm{K}$ metasomatism and sericitization (Fig. 18b, d). Temperature and pressure conditions for these hydrothermal processes vary from $\sim 500{ }^{\circ} \mathrm{C}$ and $2.6 \mathrm{kbar}$ for $\mathrm{K}$ metasomatism to $\sim 290^{\circ} \mathrm{C}$ and $1.2 \mathrm{kbar}$ for sericitization.

The evolution of the Batalha hydrothermal system is similar to some of the intrusionrelated gold deposits (e.g., Dublin Gulch, Canada, Maloof et al., 2001) and porphyry Cu deposits (e.g., Lepanto, Philippines, Hedenquist et al., 1998; Escondida, Chile and Porgera, Papua New 
Guinea, Corbett and Leach, 1998; Garza et al. 2001). In these, high-temperature $\left(>400{ }^{\circ} \mathrm{C}\right) \mathrm{K}$ alteration generated by magmatic fluids was overprinted by moderate- to low-temperature (400-200 ${ }^{\circ} \mathrm{C}$ ) alteration, mainly resulting in sericitization (Sillitoe, 1993; Hedenquist et al., 1998). Gold mineralizations in intrusion-related gold deposits are most commonly associated with late stage sericitic alteration (Sillitoe, 1991; Lang and Baker, 2001). In porphyry deposits, gold is usually related to the $\mathrm{K}$ alteration stage, but association with sericite, chlorite or clay alteration assemblages has also been reported for the Dizio and Didio (Phillipines) and Grasberg (Indonesia) Au-rich porphyry Cu deposits (Corbett and Leach, 1998).

The IV $(\mathrm{F})$ and IV $(\mathrm{F} / \mathrm{Cl})$ of the hydrothermal biotite of Batalha show affinity with fluids of the porphyry $\mathrm{Cu}$ and $\mathrm{Sn}-\mathrm{W}-\mathrm{Be}$ deposits. Estimated $\log \left(f \mathrm{H}_{2} \mathrm{O}\right) /(f \mathrm{HF})$ values are lower than those of porphyry $\mathrm{Cu}$ deposits (Fig. 11), possibly indicating higher $f \mathrm{~F}$ in the hydrothermal fluids. This could reflect either a more differentiated magma in relation to those associated to porphyry $\mathrm{Cu}$ deposits or an early vapor saturation that may have resulted in removal of $\mathrm{Cu}$ from the melt as chlorine complexes (Candela, 1989).

The Batalha granite differs from intrusion-related gold systems in showing extensive hydrothermal alteration, undetectable or very low $\mathrm{Bi}$, Mo and As contents and metallogenetic specialization of the Tapajós Gold Province, without any known Sn and W deposits. The Batalha system differs from the porphyry $\mathrm{Cu}$ deposits in its depth of emplacement and $\mathrm{fO}_{2}$ conditions. The Batalha granite has a signature of mesozonal granitoids, yet porphyry systems are related to epizonal settings. Oxygen fugacity of $\mathrm{Cu}$-Au porphyries typically falls in the field between nickel-nickel oxide (NNO) and hematite-magnetite (HM) oxygen buffers, implying a strong association with highly oxidized I-type magnetite series granitoids. In contrast, the Batalha granite reflects relatively reduced conditions close to the NNO buffer, suggesting affinity of the Batalha mineralization with intrusion-related gold systems (Lang and Baker, 2001). However, reduced systems associated with magnetite-free granitoids have also been related to Au-rich porphyry mineralization (Rowins, 2000). The relatively reduced I-type granitoids may be more favorable progenitors for both Au-rich, Cu-poor porphyry and intrusion-related gold deposits because magnetite, the main sink for gold at the magmatic stage, crystallizes in lesser amounts, resulting in gold concentration in the hydrothermal fluids (Leveille et al., 1988). These reduced systems have potential to transport as much gold as the classic oxidized porphyry Cu systems, but significantly less copper (see Leveille et al., 1988).

Intrusion-related gold systems have been formed mainly during the Phanerozoic, but Proterozoic and also Archean deposits have been described (Lang and Baker, 2001). Porphyry $\mathrm{Cu}$ deposits are predominantly Tertiary, but deposits of other ages are recognized as well. Examples of large Proterozoic porphyry $\mathrm{Cu}$ deposits are few (e.g., Haib in southern Namibia and 
Malanjkand in India; Porter, 2001). Other Precambrian porphyry $\mathrm{Cu}$ deposits (including Au-rich deposits related to ilmenite-bearing, reduced I-type granitoids) are the Neoproterozoic 17 Mille Hill deposit and the Late Archean deposits of Boddington in Australia, and Clark Lake and Troilus in Canada (Rowins, 2000).

The relatively young age of the porphyry and shallow intrusion-related deposits is ascribed to high erosion rates in volcano-plutonic arcs, although changes from episodic tectonic processes in the Middle Archean and Proterozoic to continuous processes in the Phanerozoic could result in significant differences in overall tectonic controls and should be considered (Goldfarb et al., 2001). The Batalha system (1.88 Ga) correlates with the final stage of one of the most important episodes of Paleoproterozoic juvenile crustal growth $(\sim 2.1-1.8 \mathrm{Ga})$. The latter is, according to Goldfarb et al. (2001), related to major mantle overturning with plumes causing heating at the base of the crust, massive melting, granitoid emplacement, depletion of lower crust and formation of extensive buoyant continental crust. The resultant crustal blocks are important for mineral resources and, besides orogenic lode-gold deposits (Goldfarb et al., 2001), can host intrusion-related (as defined by Lang and Baker, 2001), porphyry and epithermal deposits.

\subsection{Regional implications}

The $\sim 1880$ Ma Batalha granite has been attributed to the $\sim 1870$ Ma Maloquinha intrusive suite (Almeida et al., 2000), but its mineralogy, chemistry, and tectonic environment rather relate it to the $\sim 1880 \mathrm{Ma}$ Rosa de Maio granite, which belongs to the late- to post-tectonic calc-alkaline granites of the Parauari magmatic event $(\sim 1.92-1.88 \mathrm{Ga})$. This event generated the younger calcalkaline magmatic arc of the Ventuari-Tapajós (or Tapajós-Parima) Province in an oceancontinent orogeny associated with shallow east-dipping subduction (Santos et al., 2000).

Well-preserved Paleoproterozoic volcanic-hosted gold-bearing quartz-alunite highsulphidation epithermal systems were recently discovered in the 1.89-1.87 Ga Iriri Group of the Tapajós Gold Province (Jacobi, 1999; Juliani et al., 2000; Nunes et al., 2000). Sulphur, deuterium and oxygen stable isotope compositions of alunite from the epithermal systems related to calc-alkaline granite and granophyry intrusions in particular, support a predominance of magmatic fluid with subordinate meteoric water contribution (Juliani et al., 2000). These intrusions were epithermally affected by early $\mathrm{Na}$ metasomatism followed by intense $\mathrm{K}$ metasomatism, propylitization and sericitization, identical to those described from Batalha. This suggests a genetic link between epithermal and granite-hosted hydrothermal systems. Highsulphidation quartz-alunite epithermal systems and intrusion-related gold systems are not genetically linked (Sillitoe, 1991) but a direct spatial and temporal relationship between epithermal and porphyry deposits can be inferred elsewhere (Sillitoe, 1993). For example, a 
connection between a porphyry and high-sulphidation system was described by Hedenquist et al. (1998) for Far Southeast-Lepanto (Philippines).

This conceptual model is of great importance for mineral exploration because epithermal gold deposits, especially high-sulphidation systems, are common in areas with appropriate erosion level for exposure and preservation of Au-rich porphyry deposits (Sillitoe, 1993). In Precambrian terrains, however, high-sulphidation epithermal systems are rare and only few metamorphosed examples have been described; these include the Neoproterozoic Hope Brook deposit (Dubé et al., 1995) and the Paleoproterozoic Enåsen deposit (Hallberg, 1994). Thus, the recognition of a well-preserved Paleoproterozoic epithermal (and possibly porphyry-related) system in the Tapajós Gold Province provides an important key to the understanding of preservation and evolution of Precambrian terrains and associated gold-copper metallogeny. The Batalha system shows characteristics of both intrusion-related gold and gold-rich, copper-poor porphyry deposits. However, if a connection of the Batalha magmatic-hydrothermal system with quartz-alunite high-sulphidation epithermal systems is confirmed, affinity with porphyry systems could be reinforced.

The metallogenetic specialization described from Batalha provides new insights into the exploration models and prospects for the Tapajós Gold Province. In addition to epithermal and orogenic lode-gold, high-grade low-tonnage gold deposits (Goldfarb et al., 2001), the province offers potential for low-grade, large-volume porphyry-related deposits in a shallower Batalha type environment as well as base metals in more oxidized granite systems, similar to those described by Lamarão et al. (submitted). The relatively reduced Batalha system calls in exploration for gold at distal parts of the granite intrusions in the Tapajós Gold Province, especially in structurally controlled sheeted sulphide veins and sulphide replacement bodies (see also Rowins, 2000).

\section{Acknowledgements}

The authors would like to thank the Fundação de Amparo à Pesquisa no Estado de São Paulo for financial support (grant 98/02567-6), PRONEX/CNPq/UFPA (662103/1998) and Conselho Nacional de Pesquisa for the research scholarship granted to R.H. Corrêa-Silva. We are greatly indebted to P. Eilu, R. Dall'Agnol and O.T. Rämö for their reviews of the manuscript, which significantly improved this paper, and to I. McReath and T. Benevides for helpful discussions and aid with the English revision. The authors are also grateful to $\mathrm{M}$. de S. Mansueto, E. Ruberti and S.R.F. Vlach for technical support at the IGUSP MicroProbe Lab., and to Rio Tinto Desenvolvimentos Minerais for the samples and field work support. This is a contribution to the IGCP 426 (Granite Systems and Proterozoic Lithospheric Processes). 


\section{CAPÍTULO V}

(Anexo III)

\section{EVALUATION OF ALUNITE ARGON AGES AND FLUID INCLUSION INTEGRETY: STEP-WISE NOBLE GAS HEATING EXPERIMENTS ON 1.87 GA ALUNITE FROM TAPAJÓS GOLD PROVINCE, BRAZIL}

\section{Abstract}

Quantitative analyses are reported for active $\mathrm{N}_{2}, \mathrm{CH}_{4}, \mathrm{CO}, \mathrm{CO}_{2}, \mathrm{H} 2, \mathrm{O}, \mathrm{HF}, \mathrm{HCl}, \mathrm{H}_{2} \mathrm{~S}$, $\mathrm{SO}_{2}$ ) and noble (He, Ar, Ne) gas released by crushing and step-heating gas extraction experiments on an alunite from the Tapajós gold province in Brazil.

The alunite occurs within quartz-alunite alteration of silicified breccia underlying $a$ postvolcanic caldera hydrothermal silica cap situated on the ancient margin of the Amazonian craton. This oldest known dated occurrence of alunite $\left({ }^{40} \mathrm{Ar}{ }^{39} \mathrm{Ar}\right.$ dated at $\left.1.87 \mathrm{Ga}\right)$ is typical of alunite formed in a high-sulfidation magmatic hydrothermal environment, and provides a geologically long duration test for the retention of gas species in alunite. This alunite has suffered minimal post depositional thermal stress or tectonic deformation buried in a shallow graben structure. Our detailed analysis of one alunite combined with data from argon age spectra temperature release profiles from ten related samples define limits on the preservation of originally trapped gas in fluid inclusions and on the retention of radiogenic argon for geochronologic applications.

Variations in the isotopic release profiles of helium, neon, and argon from alunite suggest possible radiogenic and nucleogenic processes effecting noble gas isotopic chemistry, quantify diffusion properties, and identify gas residence sites within alunite. Alunite undergoes OH-loss below $500^{\circ} \mathrm{C}$ and $\mathrm{K}_{-} \mathrm{SO}_{4}$ structural breakdown above $600^{\circ} \mathrm{C}$, with both events influencing gas release patterns.

Three gas retention sites are recognized in alunite : 1) fluid inclusions (FI), 2) mineral structure OH intervals, and 3) alunite crystal structural matrix (XM).

Fluid inclusions generally are $\leq 1 \mu$ with variable but high vapor/liquid, and entrapped gas is released quantitatively at $200^{\circ} \mathrm{C}(\approx 1 \mathrm{hr}$.). Multiple evidence supports the conclusion that the gas is that originally trapped in alunite at the time of crystallization. $\mathrm{H}_{2} \mathrm{O}$ is $32 \%$ of total gas, $\mathrm{H}_{2} \mathrm{~S} / \mathrm{SO}_{2}$ is approximately $4: 1$ to $2: 1, \mathrm{~N}_{2} / \mathrm{Ar}$ is 0.3 to 96.3, and only ppm levels of $\mathrm{O}_{2}, \mathrm{HCl}$, and $\mathrm{HF}$ were detected. Very large amounts of $\mathrm{H}_{2}$ and $\mathrm{CO}$ were detected, though $\mathrm{CO}_{2} / \mathrm{CH}_{4} \approx 12.8$ and $\mathrm{H}_{2} \mathrm{~S}_{\mathrm{SO}} \approx 2.3$, indicating thermodynamic disequilibrium for some species and hints to gas trapping mechanisms. Helium is 214 ppm. FI helium is approximately $4 \%$ of total with $R / R a=$ 
19.5, whereas XM helium is approximately $65 \%$ of total released helium with $R / R a=0.2-2.0$. $\mathrm{FI}^{40} \mathrm{Ar}{ }^{36} \mathrm{Ar} 3=584-629$ and matrix ${ }^{40} \mathrm{Ar}{ }^{36} \mathrm{Ar}>9.6 \times 104$. For all samples (excluding fluid inclusions $) \geq 95 \%$ of argon is released over a $125^{\circ}$ temperature range within $525^{\circ}-725^{\circ} \mathrm{C}$.

Low temperature (FI) release ${ }^{38} \mathrm{Ar}{ }^{36} \mathrm{Ar}=0.0-0.064$ and high temperature $(X M)$ release ${ }^{38} \mathrm{Ar}{ }^{36} \mathrm{Ar}=3.6-14.7$ which suggest chlorine $(n, \gamma)$ and potassium-41 $(n, \alpha)$ in situ reactions from U-Th derived neutrons with trace $\mathrm{Cl}$ over the $1.87 \mathrm{Ga}$ existence of the alunite. The age increase effect of ${ }^{36} \mathrm{Ar}$ production from $\mathrm{Cl}$ nucleogenic reactions in correcting for atmospheric ${ }^{40} \mathrm{Ar}$ in age equations (can be very large) is typically 1-5 Ma and generally is insignificant to determined argon age. U-Th decay over this time contributed $4 \mathrm{He}(\alpha)$ buildup in the XM sites. Atmospheric corrected excess ${ }^{21} \mathrm{Ne}{ }^{22} \mathrm{Ne}=0.028-0.409$ points to post- crystallization nucleogenic neon production via appropriate $(\alpha, n)$ reactions within alunite.

Diffusion coefficients and activation energies determined using Arrhenius plots indicate two distinct populations of Tapajós alunite, a high temperature group (HTG) and a low temperature group (LTG), also defined by their $\delta^{34} \mathrm{~S}$ values and indicated $\Delta \delta^{34} S$ (alunite-pyrite) temperatures. Argon $\log$ Do $=2.45(L T G)$ and $=15.33$ (HTG) with activation energies of 225 $(\mathrm{kJ} / \mathrm{mole})$ and $465(\mathrm{~kJ} / \mathrm{mole})$ respectively. Helium diffusion in alunite is quantified with log Do = -4.33 and $E=106.8(\mathrm{~kJ} / \mathrm{mole})$. Model calculations of simplistic $1 / \mathrm{e}$-folding times and diffusion distance-time curves indicate that helium should remain in alunite for millions of years at approximately $\leq 100^{\circ} \mathrm{C}$, whereas alunite below $200-225^{\circ} \mathrm{C}$ will retain argon virtually indefinitely. Alunite with a post-formation low to moderate temperature and deformation history appears to be an ideal mineral host, preserving both fluid inclusion gas indicative of the highsulfidation geochemical environment and processes of transport and deposition. Our data confirm results of others that alunite is a suitable potassium-bearing mineral for argon geochronologic applications, and demonstrate its' usefulness even in extremely old geologic settings.

\section{Introduction}

The discovery of $1.87 \mathrm{Ga}$ alunite as large intergrown crystals from the Tapajós gold district in the Brazilian Amazonian craton offers an unprecedented opportunity to evaluate the capacity of alunite to retain original noble gas and fluid inclusion compositions. In particular, these alunites afford a broad window of time during which geologic processes could affect noble and active gas compositions, fluid inclusion contents, and noble gas isotopic proportions. Alunite occurrences commonly exhibit attributes that strongly link their formation to magmatic and hydrothermal processes (Rye, et.al., 1992; Rye,1993). 
Understanding the extent of initial volatile preservation, or identifying processes which modify retained volatiles, provides important constraints on these processes in interpreting alunite-hosted fluid inclusion gas data. Is fluid inclusion gas of magmatic steam alunite a sample of magmatic volatiles? We further assess the alunite crystal structure retention of argon for dating purposes. In another paper, (Landis and Rye, this volume) results are presented on gas chemistry data of fluid inclusions in alunite from a variety of deposits that are consistent with geologic and geochemical constraints for those deposits. Likewise the argon geochronology of the $1.87 \mathrm{Ga}$ Tapajós deposit, also discussed in this volume (Juliani et al., this volume), gives a picture of a remarkable history of argon retention in most alunite with minor loss in sheared samples. In this paper we present the results of active gas $\mathrm{N}_{2}, \mathrm{CH}_{4}, \mathrm{CO}, \mathrm{CO}_{2}, \mathrm{H}_{2}, \mathrm{O}_{2}, \mathrm{HF}, \mathrm{HCl}$, $\mathrm{H}_{2} \mathrm{~S}, \mathrm{SO}_{2}$ ) and noble gas ( $\mathrm{He}, \mathrm{Ar}, \mathrm{Ne}$ ) compositions determined during crushing and step-wise heating of a single sample of coarse alunite from Tapajós. In conjunction with argon thermal release experiments on 10 irradiated alunites from the Tapajós district, we use these data to recognize three discrete sites of gas retention, and to determine model diffusion properties of He, $\mathrm{Ar}, \mathrm{Ne}$ in alunite. As the released gas can be shown to be derived from both fluid inclusions, and mineral structure we use the data to provide an extreme test (approximately 1.87 Ga duration) of the general integrity of fluid inclusions in coarse alunite preserving samples of primary gas compositions of the parent hydrothermal fluids as well as the reliability of argon ages.

Our results show that the fluid inclusions in $1.87 \mathrm{Ga}$ alunite retain most of their primary active and noble gas compositions, with predicted noble gas modifications from radiogenic and nucleogenic reactions. We assert that if alunite retains noble gas over very long periods of geologic time, then active gas in fluid inclusions from much younger alunite deposits reliably will characterize the mineralizing fluids trapped at the time of alunite deposition. Volatile chemistry will have genetic significance to processes of mineral transport, deposition, source(s), and fluid trapping mechanisms. Others have shown alunite to be a feasible host for $\mathrm{K}-\mathrm{Ar}$ and ${ }^{40} \mathrm{Ar} /{ }^{39} \mathrm{Ar}$ geochronology (Ashley and Silberman, 1976; Vasconcelos, et.al., 1994; Vasconcelos, 1999; Bird, et.al., 1990; Dammer, 1995). With our study, we confirm their conclusions and derive particulars on argon systematics, diffusion characteristics, and closure temperatures. As anticipated from the argon geochronology of the Tapajós alunite reported by Juliani et al., (this volume) argon diffusion coefficients in alunite are so low that coarse alunites can be expected to give reliable argon ages. Finally, the time-temperature window of argon loss in alunite is quantified. 


\section{Experimental Methods}

\section{Instrumental}

\section{Noble and Active Gases and Fluid Inclusions}

Both noble gas abundance and isotopic composition, and active gas mixture compositions were determined on a newly developed noble gas vacuum system with a versatile custom manifold, quadrupole mass spectrometer (QMS), and MAP215-50 (MAP) static high resolution sector mass spectrometer with both faraday and ion counting modes. The extraction manifold is assembled with high conductance 3/4" diameter stainless steel tubing, Varian minivalves (manual and pneumatic operation), and $\mathrm{Cu}$ gasketed 1.33" conflat flanges, and is bakeable to $200^{\circ} \mathrm{C}$ with either heating tapes or a blanket oven. Features include SAES ST-707 (GP-50) and nubbin getters, a tantalum crucible (molybdenum liner) low blank furnace (LBF) capable of $1600^{\circ} \mathrm{C}$, two Displex DE-204 cryogenic charcoal traps (to approximately $12^{\circ} \mathrm{K}$ and temperature controlled), various charcoal and liquid nitrogen traps, calibrated expansion volumes, a Pfeiffer Vacuum Prisma quadrupole mass spectrometer (QMS) with QuadStar software, Dorflinger and Peterson pipette systems for dispensing isotopic and gas mixture reference gases, and inline volume pipette inlet to the static sector mass spectrometer (MAP215-50), all operated with custom LabView software in semi-automated fashion.

Additional valve arrangements, cryogenic traps, and molecular sieve traps, capillary jet separators, and sample mounting hardware enable the extraction of dissolved gas from water samples, and tritium - $3 \mathrm{He}$ measurements. Our primary reference gas is a remixed, ultra-purified air from Scott Marrin (Ref \#: CC121990, Riverside, CA) with a NIST traceable air mixture, and atmospheric noble 7 gas content, that is used both for QMS gas and noble gas calibration and MAP215-50 noble gas calibration.

Standards have been cross-checked with lab air, and Loveland Pass air with corrections for temperature-pressure-relative humidity. The extraction-gas purification manifold is pumped by both a $180 \mathrm{l} / \mathrm{s}$ drag turbo (approximately 2x10-9 Torr), and the QMS is pumped by a $65 \mathrm{l} / \mathrm{s}$ turbo. Both turbomolecular pumps are backed by oil-free membrane pumps. Ultra-high vacuum (UHV) volume expansions, cryogenic separator heads, and inlet to mass spectrometer (MAP) are maintained at approximately 3x10-10 torr with a 40 1/s StarCell, while the MAP is kept below 3x10-11 torr between analyses with a SAES ST-101 getter and a 40 1/s triode pump. Splits of noble gas remaining in the UHV manifold section after analysis are removed through the QMS turbo and not the StarCell or triode ion pumps.

The instrument has a virtually unmeasurable ${ }^{40} \mathrm{Ar}$ rate of rise, and negligible backgrounds on the peaks of interest. Both QMS and MAP operate in static mode during noble gas analysis, whereas a variable leak valve through a separate chamber port on the QMS is used for dynamic 
pumping during gas mixture analyses. Resolution of MAP is optimized for ${ }^{3} \mathrm{He}$ with a resolution of approximately 640 . Sensitivity is given in Table 1.

Table 1. Instrument Sensitivity Calibration Factors

\begin{tabular}{|c|c|c|c|c|}
\hline Isotupe & Mass spectrometer & Defertor & Senvitivity & Units \\
\hline${ }^{4} \mathrm{H}^{2}$ & $\mathrm{MAP}$ & Faralay & $8.10 .31 \mathrm{a}^{-12}$ & mokivolt \\
\hline 'Hに & $\mathrm{MAP}$ & DIC & $1.363 e^{-93}$ & mokeps \\
\hline Ne-isotopes & MAP & Faralday & $2.35 a^{-11}$ & mole: wh \\
\hline Ne-isotopes & MAP & DIC & $1.40 a^{-19}$ & mokeps \\
\hline$" \mathrm{Ar}$ & QMS & $\mathrm{AM}$ & $341 \mathrm{e}^{-3}$ & moksamp \\
\hline${ }^{3} \mathrm{Ar}$ & QMS & $A M$ & $3.32 \mathrm{~L}^{-3}$ & mok amp \\
\hline +"Ar & QMS & $A M$ & $3.63 \mathrm{a}^{-3}$ & moks amp \\
\hline
\end{tabular}

Note: M.AP = Mass Analyzer Products 215-50, QMS $=$ Pfeiffer Prisnna 0-340.AMU, DIC $=$ di gital ion counting i Champeltron and Ortec electronics). $\mathrm{AM}=$ analog multiplier ( $\mathrm{SEV} 217 \mathrm{i}, \mathrm{cps}=$ counts per second. Precision: faraday $\leq \pm 0.02 \%$, DIC $₫ \pm 0.4 \%$. AM $\Xi \pm 0.5 \%$.

\section{Argon Geochronology}

Argon geochronology of ten Brazilian alunite samples was conducted in the USGS Denver argon laboratory. In this laboratory samples are stepheated in a low-blank, doublevacuum internal resistance furnace, gases are processed through an ultra-high vacuum extraction line, and purified argon isotopes are analyzed on a Mass Analyzer Products 215 rare-gas mass spectrometer equipped with a Niertype source and Faraday and electron multiplier detectors.

The double-vacuum resistance furnace consists of a tantalum crucible with a molybdenum liner; an outer water-cooled can surrounds the crucible. Within the outer can, a tungsten-heating element surrounds the crucible and both are surrounded by a heat shield that protects the outer can. The heating element volume is continually pumped to a vacuum of less that $1 \times 10-7$ torr. A furnace controller that raises the crucible to a programmed temperature in one to two minutes powers the heating elements. Temperature of the sample is measured by a thermocouple attached to the crucible and maintained to $+2{ }^{\circ} \mathrm{C}$. The crucible is on-line with the extraction line made of pyrex and stainless steel and the gases released during each heating step are cleaned with $\mathrm{Zr}-\mathrm{Al}$ and $\mathrm{Zr}-\mathrm{V}-\mathrm{Fe}$ alloy getters. Purified argon is transferred from the cleaning chamber to the inlet manifold by freezing onto charcoal within a pyrex finger with liquid nitrogen. After transfer, expansion, and volume splitting, argon is expanded into the mass spectrometer and analyzed. Isotopic abundances of five argon isotopes $\left({ }^{40} \mathrm{Ar},{ }^{39} \mathrm{Ar},{ }^{38} \mathrm{Ar},{ }^{37} \mathrm{Ar}\right.$, and ${ }^{36} \mathrm{Ar}$ ) are determined over multiple analysis cycles and the data are regressed to time zero (time of gas inlet). 


\section{Sample and Gas Processing}

Ten alunite samples were analyzed in this study. One of these, Tapajós alunite No. 16/18, was used in the comprehensive study of structural and fluid inclusion noble and active gases as well as argon geochronology; the sample and gas processing procedures for this sample are first described below. The sample and gas processing procedures for the other nine alunites, which were exclusively used for argon geochronology, are described in the second part of this section.

\section{Noble and Active Gases and Fluid Inclusions}

A single sample, Tapajós alunite 16/18, consisting of several ethanol washed, weighed pieces of alunite (total: $6.96 \mathrm{~g}$ ), 0.5 to $1.0 \mathrm{~cm}$ on a side, was analyzed in several steps during this study, as described below.

The sample was crushed off-line under sealed vacuum, returned to the manifold, and gases extracted and analyzed. It was then heated to $200^{\circ} \mathrm{C}$ for 60 minutes twice in the same crush tube and gases analyzed. These gas extractions were analyzed both by QMS for active gas mixtures and by MAP and QMS for noble gas elemental and isotopic composition. Larger remaining pieces $(0.1<\mathrm{d}<1.0 \mathrm{~mm})$ were then placed into a on-line stainless steel tube resistance furnace. The sample was heated to $200^{\circ} \mathrm{C}$ and held 60 minutes a third time. The third $200^{\circ} \mathrm{C}$ thermal extraction did not yield sufficient gas for QMS analysis and only noble gas analyses were performed. The second $200^{\circ} \mathrm{C}$ thermal extraction yield was $<2 \%$ of total low temperature gas yield, indicating release of nearly all fluid inclusion contained gas in the previous crush and first $200^{\circ} \mathrm{C}$ release.

Gas released from subsequent heating in $100^{\circ} \mathrm{C}$ increments of 10 minute ramp and 60 minute duration each, to $700^{\circ} \mathrm{C}$, was analyzed only for He-Ne-Ar. Static QMS analysis of active gas is not feasible as chemical interactions of gas species with the hot thoriated tungsten filament modifies the composition. To test QMS source effects on analytical results, the same gas was analyzed at both the $1 \mathrm{ma}$ and 0.4 ma filament current, at several EAV (electron accelerating voltages) to assess EID (electron impact desorption) shifts in composition, and on a second QMS fitted with a separate thoriated iridium filament which operates at a much lower temperature. As long as the gas was dynamically pumped during analysis, no appreciable differences in gas chemistry was noted compared to the calibrated configuration.

Off-line crushing mentioned above was accomplished in a 7/8" diameter annealed 304 stainless steel tube, butt welded closed on one end, and fitted with a vacuum valve (Nupro 6BG) on the other. The tube containing the sample was attached to the noble gas extraction manifold and pumped overnight to mid- 10-8 Torr. The tube was removed from the manifold with the 
valve closed, and the contents crushed with a 5 ton press releasing fluid inclusion contained gas, and returned to the manifold for extraction of the mechanically released gas. A $5 \mathrm{cc}(0.33 \%)$ split of total gas was dynamically analyzed in the QMS, with corrections applied for background, sensitivity relative to nitrogen, and isobaric overlap in AMU peaks by a matrix solution. Results are in mole fractions which are then calculated to total moles per gram based on argon sensitivity and weight of sample and split fraction corrections. QMS analytical uncertainty is typically \pm 0.5 $\%$ error, with calibration and other error propagation yielding a total estimated error of $<2 \%$.

The remaining $99.6 \%$ of gas was then processed for noble gas purification, separation, and analysis by trapping evolved gas in a LN2 trap, exposing noncondensible gas to ST-707 at $320^{\circ} \mathrm{C}$ for 5 mins., ST-707 at $280^{\circ} \mathrm{C}$ for 5 mins., freezing argon-krypton-xenon onto a LN2charcoal trap, freezing the purified $\mathrm{He}-\mathrm{Ne}$ on charcoal at $13^{\circ} \mathrm{K}$ for 10 mins., concentrating and isolating the gas in a forward small volume section of the manifold prior to analysis. The argon was released from the LN2 -charcoal trap and expanded statically into the QMS for analysis, while the cryogenic trap was warmed to $45^{\circ} \mathrm{K}$, to release only $\mathrm{He}$, in a procedure analogous to Lott and Jenkins (1984) and Lott, (2001). After helium was expanded into the MAP, analyzed, and pumped away, the cryogenic trap was warmed to $75^{\circ} \mathrm{C}$ to release neon for analysis.

Neon isotopes were measured by ion counting, with corrections for background, ion doublets from ${ }^{40} \mathrm{Ar}^{++}$and ${ }^{44} \mathrm{CO}_{2}{ }^{++}$, and reference standard corrections. Source non- linearity or mass discrimination has not been observed in our MAP, at the gas pressures released by these samples (Farley, 2000). Crushing and furnace procedural blanks generally were trivial and "airlike" in composition, but corrections were applied as appropriate. Procedural errors are $\leq \pm 0.5 \%$ to $\leq \pm 0.8 \%$ ( $1 \sigma$ as percent of mean). After each $100^{\circ} \mathrm{C}$ heating step (60 mins.), gas was removed and the tube furnace was allowed to cool quickly to room temperature during analysis, and then heated to the next $100^{\circ} \mathrm{C}$ higher temperature. Over the several days of this experiment, the sample was vacuum pumped briefly only while at ambient lab temperature.

Alunite is a hydrated sulfate mineral that undergoes $\mathrm{OH}$ - loss near $500^{\circ} \mathrm{C}$ and $\mathrm{SO}_{3}$ loss above $600^{\circ} \mathrm{C}$ (Slansky, 1973; Fielding, 1981; Fielding and Sclar, 1980). As temperature of extraction approached $400-500^{\circ} \mathrm{C}$, water from alunite $\mathrm{OH}$ sites combined with $\mathrm{SO}_{2}$ from sulfate sites to produce sulfuric acid. Though $\mathrm{H}_{2} \mathrm{SO}_{4}$ was frozen quickly into an LN2 trap, we were unable to restrict its destructive effects on copper gaskets and valve parts in the exposed section of the manifold. Extensive disassembly and ultra-clean washing of the affected section, gasket replacement, valve repair, and reassembly and heating tape bakeout was required to restore UHV conditions to the manifold. As our sample size was nearly $7.0 \mathrm{~g}$ alunite, the quantity of decomposition products was large. We do not recommend repeating this experiment without adequate methods of restricting the water and acid products to a 'throw-away' section of 
manifold. Normal milligram quantities of alunite used for argon geochronology analyses, do not present a problem to UHV manifold and getters.

\section{Argon Geochronology}

Ninety-nine percent pure alunite was picked from vein material collected from 3 surface samples (X numbers) and from 6 drill core samples (FV numbers). Each alunite was gently ground to 250-125 micrometers. Minor pyrite $(<1 \%)$ was not removed. The alunite samples were cleaned with reagent-grade acetone, alcohol, and deionized water and air-dried. Eight to $12 \mathrm{mg}$ of each alunite were wrapped in aluminum foil packages.

Two aliquots of one alunite sample, FV3-1/16, were irradiated in two different irradiation packages and analyzed twice. Seven of the ten samples were encapsulated in silica glass vials with other samples and fluence standards adjacent to each unknown. Three of the ten samples were each encapsulated alone in "break-seal" silica glass vials and evacuated to better than 10-8 torr; for these three samples, the neutron-fluence standards were enclosed in adjacent silica vials. One of the two aliquots of sample FV3-1/16 was irradiated in a "breakseal" vial; the other was irradiated the other way. The standard for this experiment is hornblende MMhb- 1 with percent $\mathrm{K}$ $=1.555,40 \mathrm{ArR}=1.624 \times 10-9 \mathrm{~mole} / \mathrm{gm}$ (Samson and Alexander, 1987), and $\mathrm{K}-\mathrm{Ar}$ age $=$ $523.1+2.6 \mathrm{Ma}$ (age reevaluated by Renne et al. 1998).

For irradiation, an aluminum canister was loaded with the silica vials. The samples were irradiated in three different irradiation packages. The first irradiation package contained FV3$1 / 16$ in a "breakseal" vial and it was irradiated for 30 hours in the TRIGA reactor at the U.S. Geological Survey in Denver, Colorado. Because of the promising results of this experiment, eight additional alunite samples were irradiated for 129 hours in a second package; the longer irradiation period was employed to acquire more optimal ${ }^{40} \mathrm{Ar}_{\mathrm{R}} /{ }^{39} \mathrm{Ar}_{\mathrm{K}}$ ratios. This second irradiation package also contained a "breakseal" vial. A third irradiation for 30 hours contained one alunite sample in a "breakseal" vial. The alunites and standards were analyzed in the Denver Argon Laboratory of the U.S. Geological Survey using a Mass Analyser Products 215 rare-gas mass spectrometer on a Faraday-cup collector. The vacuum-encapsulated vials were loaded into the extraction system and baked at $250^{\circ} \mathrm{C}$ before the vacuum seal was broken on line and the released gas was analyzed to determine whether any argon had been recoiled from the sample during irradiation.

All alunite samples were heated in a double-vacuum low-blank resistance furnace for length of heating intervals (in minutes) indicated for each, in a series of 8 to 17 steps, to a maximum of $1350^{\circ} \mathrm{C}$, and analyzed using the standard stepwise heating technique described by Snee (in press). Each standard was degassed to release argon in a single step at $1250^{\circ} \mathrm{C}$. Mass 
discrimination was determined by calculating the ${ }^{40} \mathrm{Ar} /{ }^{36} \mathrm{Ar}$ ratio of aliquots of atmospheric argon pipetted from a fixed pipette on the extraction line; the ratio during this experiment was 298.9, which was corrected to 295.5 to account for mass discrimination. Final isotopic abundances were corrected for all interfering isotopes of argon including atmospheric argon. 37 Ar and 39Ar, which are produced during irradiation, are radioactive and their abundances were corrected for radioactive decay.

Abundances of interfering isotopes from $\mathrm{K}$ and $\mathrm{Ca}$ were calculated from reactor production ratios determined by irradiating and analyzing pure $\mathrm{CaF}_{2}$ and $\mathrm{K}_{2} \mathrm{SO}_{4}$; the $\mathrm{K}_{2} \mathrm{SO}_{4}$ was degassed in a vacuum furnace prior to irradiation to release extraneous argon. Corrections for $\mathrm{Cl}-$ derived 36Ar were determined using the method of Roddick (1983). Production ratios for this experiment are available in Snee (in press). Detection limit at the time of this experiment was $2 \times 10-17$ moles of argon.

\section{Results}

Of the ten alunite samples analyzed in this study (described in Juliani, et.al. this volume), only Tapajós alunite No.16/18 is used for the comprehensive study of noble and active gases and fluid inclusions. It is from the upper levels of the volcanic ring structure volcanic complex that hosts a $1.87 \mathrm{Ga}$ gold occurrence in the Tapajós province of the Brazilian Amazon. Additional alunite samples used for argon geochronology are from both surface and drill core sites. Possible cosmogenic production of nuclides in surface samples did not occur as all were collected at sites many meters deep below the original surface, and were made accessible by active mining operations.

The Tapajós alunite is identified by Juliani et al. (this volume) as magmatic hydrothermal alunite (Rye, 1992) formed from high sulfidation mineralization genetically linked to the volcanic-magmatic activity on the then margin of the Amazonian craton. Post-caldera volcanic rocks host the high-sulfidation mineralization within explosive hydrothermal breccia bodies and massive hematite-rich vuggy silica caps. Quartz-alunite alteration forms under the silica cap as an envelope extending up to 200 meters from the breccia centers and is known to occur up to 230 meters below the surface.

Five varieties of alunite are recognized at shallow levels under the silica cap (A1-A5), of which X1-16/18 alunite is identified as A5, a late-stage rose-colored, fine-grained, randomly oriented aluntite that crosscuts and replaces the branching crystals of A4 (Juliani, et al., this volume). Fine- to medium- grained alunite associated with the silicified hydrothermal breccia cement occurs at depth in three main types (B1- B3) described by Juliani et al. (this volume).

Geologic evidence and argon geochronology argues this alunite occurrence has been 
protected since formation by burial in a shallow graben and subjected only to brief and episodic low temperature thermal (dike intrusion) and nearby shearing events not long after formation. Since early post deposition, this alunite has remained thermally undisturbed. No evidence is known for deep burial or high sustained geothermal gradients. Nor do rocks exhibit even very low grade greenschist metamorphism.

\section{Description of alunite and fluid inclusions}

\section{Mineralogy}

Alunite, a hydrated potassium-aluminum sulfate, is $\mathrm{KAl}_{3}\left(\mathrm{SO}_{4}\right)_{2}(\mathrm{OH})_{6}$. Crystal structure intervals perpendicular to the alunite $\mathrm{C}$-axis alternate between tetrahedrally coordinated sulfur bonded with oxygen and potassium, and octahedrally coordinated aluminum bonded with oxygen and $\mathrm{OH}$ structural water. Important stoichiometric substitutions of $\mathrm{Na}$ for $\mathrm{K}, \mathrm{Fe}$ for $\mathrm{Al}, \mathrm{P}$ for $\mathrm{S}$, and $\mathrm{F}$ and $\mathrm{Cl}$ for $\mathrm{OH}$ are possible. At elevated temperature, alunite loses its' structural water near $\leq 500^{\circ} \mathrm{C}$, and undergoes crystal disintegration by loss of $\mathrm{SO}_{3}>600^{\circ} \mathrm{C}$ (Slansky, 1973; Fielding, 1981; Fielding and Sclar, 1981). These crystallographic transformations and loss of alunite stoichiometric components with step heating aid gas release and possibly alter gas retention sites.

Sample X1-16/18 is pure, massive crystalline alunite comprised of smaller crystal domains of 5-20 $\mu$ thick plates commonly only 20-80 $\mu$ across (Figure 1g). Larger contiguous crystal domains $0.2-3.0 \mathrm{~mm}$ across also are common. The other alunite of this study range in crystal-domain size from that of X1-16/18 to a few $\mu$ m (examples shown in Figs. 1g, 1h, and 1i). One sample, FV3-1/12, consists of thin (a few $\mu \mathrm{m}$ ) plates that resulted from structural deformation.

\section{Alunite Chemistry}

Electron microprobe chemical analyses of representative Tapajós alunite, based upon the average of 10-12 points per sample, are given in Table 2. Data are expressed in weight \% oxides. Analyses total an average of $84.86 \mathrm{wt} . \%$, with the remainder as $\mathrm{OH}$ structural water.

A high temperature (HTG) group and a low temperature (LTG) group are recognized from the $\delta^{34} \mathrm{~S}$ alunite values and $\Delta^{34} \mathrm{~S}$ (alunite-pyrite) calculated equilibrium fractionation sulfur isotope temperatures (Juliani, et al, this volume). These two groups of Tapajós alunite also differ in their argon diffusion parameters as discussed below. Additional composition data for magmatic steam and magmatic hydrothermal alunite are given elsewhere (Juliani, et al., and Landis and Rye, this volume). In comparing these data, HTG alunite is more enriched in potassium $\left(\mathrm{K}_{2} \mathrm{O} / \mathrm{Na}_{2} \mathrm{O}=9.81\right)$ than LTG alunite $\left(\mathrm{K}_{2} \mathrm{O} / \mathrm{Na}_{2} \mathrm{O}=2.58\right)$, with slightly more 
phosphorus substitution for sulfur. Chlorine and fluorine substituted in the $\mathrm{OH}$ sites is comparable in both groups.
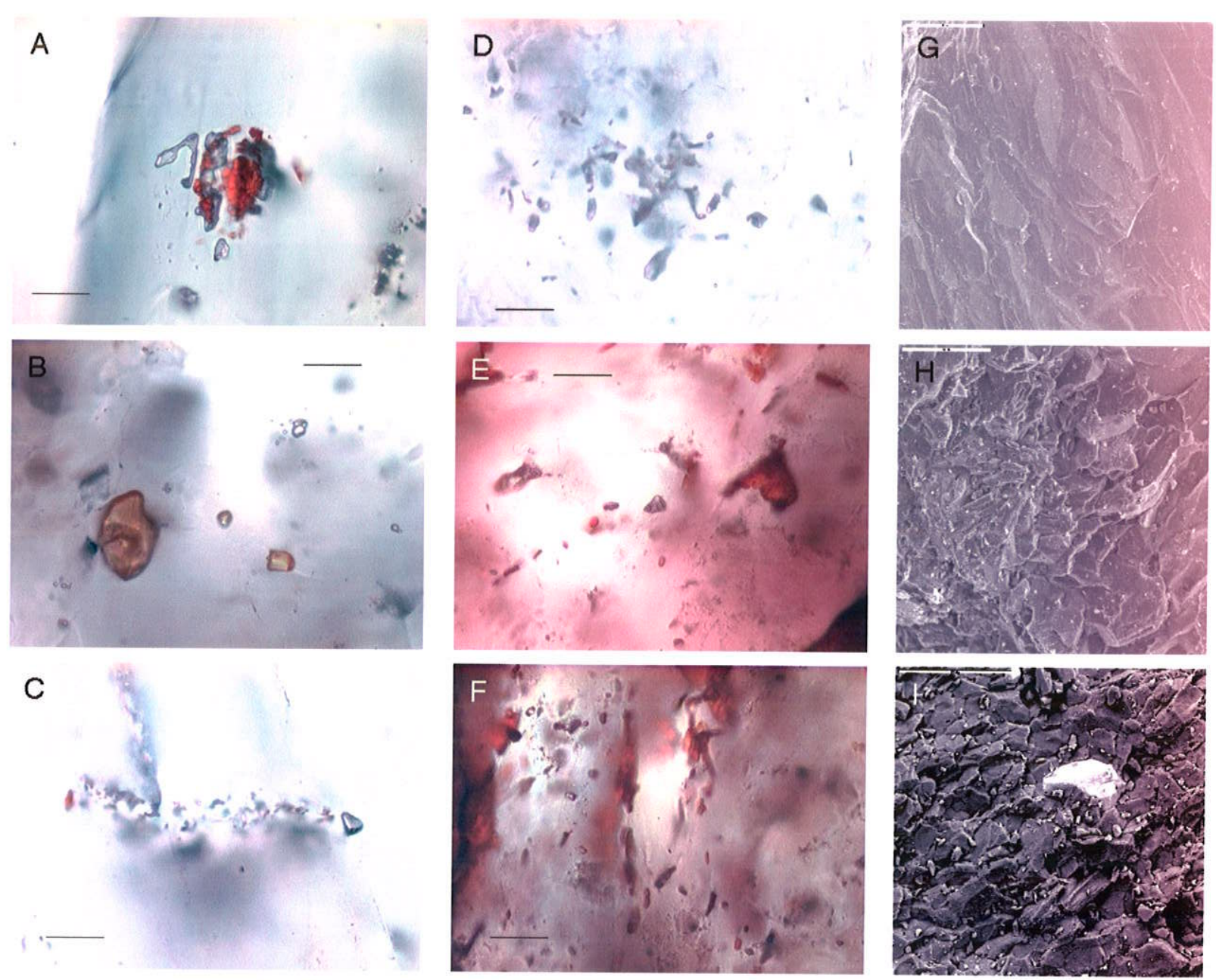

Figure 1. Photomicrograph and SEM images of alunite and hosted fluid inclusions. Images A-C are of fluid inclusions in the LTG alunite and images D-F of fluid inclusions in the HTG alunite. The scale bar in images A-F represents 1 micron. A). X1-16/18 - large gas rich Type 1 fluid inclusion with primary hematite crystals possibly the reason for nucleating a fluid inclusion defect. B). FV3-1/16-unusually large hematitic stained gas inclusions of Type 2, with < 0.1 micron inclusions visible. C) X1-16/18-Type 1 (vertical inter domain boundaries) and Type 2 (horizontal growth bands) fluid inclusions, gas rich with no visible meniscus. D). FV3-1/11 - Type 3 randomly distributed micron to submicron sized gas rich fluid inclusions. E). and F). X1-16F - larger Type 1 fluid inclusions in alunite with abundant primary hematite. Liquid meniscus seen in 0.3 micron inclusion centered in Figure E. G). SEM image of X1-16/18 LTG alunite showing massive large crystal domains and speckled holes of opened fluid inclusions (scale bar $=100$ microns). H). SEM image of X1-16G LTG alunite with moderate sized crystal domains and lighter grey hematite blebs (scale bar = 50 microns). I). FV3-1/11 HTG alunite showing disrupted micro crystal domains and bright pyrite grain (scale bar $=50$ microns). The platy smaller crystal domains are more typical of HTG alunite. Extremely rare planes of secondary fluid inclusions are not seen in any of these images.

Though Tapajós alunite exhibits magmatic hydrothermal characteristics (Juliani, et.al., this volume), there are striking similarities of HTG alunite compositions to that of other 
magmatic steam alunites, whereas LTG alunite is similar to other magmatic hydrothermal alunite compositions (Landis and Rye, this volume). The low $\delta^{34} \mathrm{~S}$ (alunite), high temperature of deposition, high $\mathrm{K} / \mathrm{Na}$, increased $\mathrm{P}$ and $\mathrm{F}$ of Tapajós $\mathrm{HTG}$ alunite samples are all indicative of a close magmatic link. The smaller crystal domains of HTG alunite might infer more rapid vapor transport and deposition. Perhaps HTG alunite formed in a transitional deposition environment between magmatic steam and magmatic hydrothermal conditions in the alteration environment of explosive hydrothermal breccia formation. We don't fully understand the significance of differences between the LTG and HTG alunite, but examine this hypothesis further in considering diffusion parameters below.

Table 2. Aserage Alunite Analyses (Eketron Microprohe)

\begin{tabular}{|c|c|c|c|c|c|c|}
\hline & \multicolumn{3}{|c|}{ Low-T } & \multicolumn{3}{|c|}{ High-T } \\
\hline Wt\% Oxides & FV3-1/16 & $x 1-16 / 18$ & $X 1-16 G$ & FV/3-1/25 & FV3-1/11 & $X 1-16 F$ \\
\hline$n=\#$ analyses & 10 & 10 & 10 & 10 & 11 & 12 \\
\hline $\mathrm{K}_{2} \mathrm{O}$ & 5.11 & 6.51 & 8.55 & 9.53 & 8.05 & 9.50 \\
\hline $\mathrm{Na}_{2} \mathrm{O}$ & 3.71 & 2.74 & 1.34 & 0.76 & 1.24 & 0.75 \\
\hline $\mathrm{SO}_{3}$ & 37.84 & 37.71 & 36.94 & 36.66 & 36.79 & 36.64 \\
\hline $\mathrm{Al}_{2} \mathrm{O}_{3}$ & 37.29 & 37.05 & 36.71 & 36.83 & 37.18 & 36.40 \\
\hline $\mathrm{P}_{2} \mathrm{O}_{5}$ & 0.28 & -.. & 0.45 & 0.50 & 0.45 & 0.34 \\
\hline $\mathrm{CaO}$ & 0.20 & $\ldots$ & 0.27 & -. & ... & -.. \\
\hline $\mathrm{BaO}$ & $\cdots$ & 0.34 & 0.76 & 0.50 & 0.37 & 0.46 \\
\hline $\mathrm{F}$ & $\cdots$ & 0.96 & 0.81 & 1.00 & $\cdots$ & $\cdots$ \\
\hline $\mathrm{Cl}$ & $\cdots$ & $\ldots$ & 0.07 & $\ldots$ & 0.05 & $\ldots$ \\
\hline Total & 84.64 & 85.46 & 85.01 & 85.46 & 84.46 & 84.15 \\
\hline Temp ${ }^{\circ} \mathrm{C}$ & & 250 & 130 & 420 & 260 & 420 \\
\hline$\delta^{34} \mathrm{~S}$ & & 26.7 & 38.2 & 14.0 & 15.8 & 14.3 \\
\hline
\end{tabular}

\section{Fluid Inclusions}

Generally fluid inclusions are $\leq 1 \mu$ diameter, with high gas/liquid ratios and are the most obvious and readily observable site of gas retention within alunite. They are too small for detailed temperature-salinity-clathrate studies (Roedder, 1984). As can be seen from the photomicrograph and SEM images in Figure 1, rare 1-2 $\mu$ gas rich inclusions can be identified.

Most inclusions are in the range of 0.2 to $0.01 \mu$ and appear also to be gas rich. As illustrated in the SEM image (Fig.1i), diffusion pathways from inclusions to crystal domain boundaries are the limiting dimensions to gas retention. Loss or exchange of gas to the surrounding environment is presumed rapid once gas reaches the edge of the crystallite.

Fluid inclusions in Tapajós alunite are typical of those observed in alunite specimens from other localities (Landis and Rye, this volume). All examined alunite exhibit the same threetype fluid inclusion occurrence: Type 1) elongated parallel to the alunite c-axis as primary inclusions, commonly concentrated at micron to sub-micron crystal domain boundaries defined 
by change in contiguous optical properties and epitaxial growth of alunite in a subtly different crystal orientation, but otherwise solid massive alunite without voids or passages at the boundaries; Type 2) primary inclusions parallel to surfaces of mineral deposition (growth bands) perpendicular to principal deposition direction (outward from base of crystal); and Type 3) randomly dispersed, somewhat elongate, primary fluid inclusions without preferred orientation or location but always observed within the interiors of optically definable crystal domains.

Importantly, LTG alunite almost exclusively exhibits Type 1 and 2, whereas HTG alunite is dominated by Type 3 fluid inclusions. Planes of pseudosecondary and secondary fluid inclusions are extremely rare. Daughter minerals were absent from the gas rich inclusions, and difficult to recognize with certainty from the rare and extremely small liquid rich inclusions. A notable exception is primary hematite, common both as solid inclusions and as nucleating defect centers for fluid inclusions. The small size and large number of fluid inclusions in alunite certainly favors preservation of trapped gas.

But at the submicron scale, this also increases the likelihood of trapping gases out of equilibrium with the bulk fluid or vapor, across large chemical gradients at the deposition interface (Landis and Rye, this volume).

\section{Active gas data from crush and heating extraction}

Crush and $200^{\circ} \mathrm{C}$ thermal release gas analyses are given in Table 3 . The gas chemistry of the Tapajós 16/18 alunite is comparable to that of other magmatic hydrothermal alunites, and is discussed with data from other alunite localities in Landis and Rye (this volume). As will be demonstrated below, this low temperature gas is dominated by release from fluid inclusions. Gas analyses in Table 3 are reported in mole percent (or ppmV) for the initial crush, and the first and second $200^{\circ} \mathrm{C}$ heating extraction of 60 minutes duration.

Total moles of gas released for each extraction is calculated from the argon calibration (moles/amp) and then a weighted sum of moles for the total of each gas is normalized to calculate Total mole fractions (percentage). Total Thermal tabulation is recast to include just the two $200^{\circ} \mathrm{C}$ thermal extractions. The second $200^{\circ} \mathrm{C}$ extraction released less than 2 mole $\%$ of total gas in these three extractions, and a subsequent third $200^{\circ} \mathrm{C}$ extraction did not yield enough gas for dynamic QMS analysis ( $<0.02$ mole\%). With the exception of water, the amounts of almost all gas species decrease with each of the three gas release events described above. The initial crushing of alunite releases fluids from the larger inclusions, and rare secondary planes and voids between crystal boundaries by breaking open these voids. Over time at $200^{\circ} \mathrm{C}$, increasing numbers of very small gas rich inclusions in the interior of crystal domains and more water-rich inclusions open either by thermal decrepitation of small inclusions or by thermal distortion of the 
crystal and diffusion of gas from inclusion sites.

Table 3a. Crush and Thermal Rekase Gas Compositions.

\begin{tabular}{|c|c|c|c|c|c|c|c|}
\hline Relense & $A r \%$ & $\mathrm{I}_{2} \mathrm{Oh}$ & $I_{2}()^{0} \mathrm{l}$ & $\mathrm{CHI}_{3} " / 3$ & $C O)^{\prime}$ & $\mathrm{CO}_{2} " \mathrm{O}$ & $\mathrm{II}_{2} " \mathrm{u}$ \\
\hline Crush $\left(22^{\circ} \mathrm{C}\right)$ & 0.302 & 29.039 & 0.859 & 0.414 & 67.708 & 0.155 & 1.51 .3 \\
\hline $1-\left(200^{\circ} \mathrm{C}-60 \mathrm{~min}\right)$ & 31.491 & 10.617 & 10.411 & 1.251 & 0.000 & 38.873 & 7.263 \\
\hline $2-\left(200^{\circ} \mathrm{C}-60 \mathrm{~min}\right)$ & 0.132 & 3.733 & 58.433 & 3.887 & 0.515 & 22.770 & 10.443 \\
\hline Total Mole $\%$ & 1.021 & 28.115 & 2.211 & 0.501 & 64.821 & 1.496 & 1.822 \\
\hline Total Thermal & 17.109 & 7.460 & 32.435 & 2.460 & 0.236 & 31.488 & 8.721 \\
\hline Relestse & $O_{2} P p m$ & IIF ppl" & $I / \mathrm{l} / \mathrm{p} m \mathrm{~m}$ & $\mathrm{II}_{2} \mathrm{~S}_{\mathrm{P}} \mathrm{Pm}$ & $\mathrm{SO}_{2} \mathrm{pmm}$ & IIe ppmI & Total Moles \\
\hline Crush $\left(22^{r} \mathrm{C}\right)$ & 8 & 30 & 6 & 34 & 8 & 11 & $7.1678 \mathrm{E}-08$ \\
\hline $1-\left(200^{\circ} \mathrm{C}-60 \mathrm{~min}\right)$ & 221 & 76 & 136 & 189 & 110 & 216 & $1.7351 \mathrm{E}-09$ \\
\hline $2-\left(200^{\circ} \mathrm{C}-60 \mathrm{~min}\right)$ & 165 & 0 & 117 & 292 & 94 & 212 & $1.4698 \mathrm{E}-09$ \\
\hline Total Nole \% & 16 & 31 & $\pi$ & 42 & 12 & 20 & $7.4883 \mathrm{E}-08$ \\
\hline Total Thermal & 200 & 41 & 128 & 235 & 102 & 214 & $3.2049 \mathrm{E}-09$ \\
\hline
\end{tabular}

Table 3b. Crush and Thermal Rekase Gas (ompositions (water tres)

\begin{tabular}{|c|c|c|c|c|c|c|}
\hline Relerise & $11 \%$ & $\mathrm{I}_{2}: 6$ & $\mathrm{CII}_{4} \mathrm{Os}$ & $c 0 \%$ & $\mathrm{CO}_{2} \mathrm{OH}$ & $\mathrm{II}_{2} \%$ \\
\hline Crush $\left(22^{\prime} \mathrm{C}^{\prime}\right)$ & 0.304 & 29.291 & 0.417 & 68.295 & 0.156 & 1.526 \\
\hline $1-\left(200^{\circ} \mathrm{C}-60 \mathrm{~m}\right.$ min $)$ & 35.150 & 11.851 & 1.296 & 0.000 & 43.390 & 8.107 \\
\hline $2-\left(200^{\top} \mathrm{C}-60\right.$ min $)$ & 0.318 & 8.980 & 9.350 & 1.239 & 54.778 & 25.123 \\
\hline Total Mole \% & 1.044 & 28.751 & 0.513 & 66.286 & 1.530 & 1.863 \\
\hline Total Thermal & 25.322 & 11.041 & 3.640 & 0.350 & 46.603 & 12.908 \\
\hline Relerse & $\mathrm{O}_{2} \mathrm{PPm}$ & $I I F p m$ & $\| C / p m m$ & $I_{2} S_{P} P m$ & $\mathrm{SO}_{2} \mathrm{PPM}$ & IIe ppum \\
\hline Crush $\left(22{ }^{\circ} \mathrm{C}\right)$ & 8 & 31 & 6 & 34 & 8 & 12 \\
\hline $1-\left(200^{\circ} \mathrm{C}-60 \mathrm{~min}\right)$ & 247 & 85 & 152 & 209 & 122 & 241 \\
\hline $2-\left(200^{\circ} \mathrm{C}-60 \mathrm{~min} !\right.$ & 398 & 0 & 282 & 704 & 226 & 509 \\
\hline Total Mole \% & 17 & 31 & 11 & 43 & 12 & 21 \\
\hline Total Thermal & 289 & 61 & 189 & .348 & 152 & 316 \\
\hline
\end{tabular}

Much higher temperature is required to release distinctive noble gas compositions from the alunite crystal structure. The noble gas data from step-heating alunite discussed below (especially argon and helium isotopes), and the diminished amount of released gas observed in the second and third $200^{\circ} \mathrm{C}$ thermal extraction, supports our assertion that 1) no alunite structural gas is released either by crushing or low temperature thermal extraction, and 2) data in Table 3 represent analyses of primary fluid inclusion gas, in large measure, sealed since time of trapping.

The sites that release gas by crushing are most likely of any to have exchanged fluids with other external fluids since their formation, and therefore may contain gas from ambient atmospheric and groundwater sources. This is because mechanical breaking of the crystal will tend to open larger inclusions and possible fractures, and these sites are most likely to have been 
open to fluid exchange after entrapment of original fluids. However, thermal release gas sites such as small primary fluid inclusions not opened by mechanical breakage of the crystal, most likely would preserve primary gas compositions originally trapped with alunite deposition.

A weighted total of $2.2 \mathrm{~mol} \%$ water for the analysis $(32.4 \%$ for weighted total thermal release) supports the observation that most fluid inclusions under microscopic examination appear gas rich. Only ppm level $\mathrm{O}_{2}, \mathrm{HCl}$, and $\mathrm{HF}$ is detected, and $\mathrm{H}_{2} \mathrm{~S}_{\mathrm{SO}} \mathrm{SO}_{2}$ is released in approximately a 4:1 to $2: 1$ ratio, consistent with the ratio predicted by Juliani et al (this volume).

The $\mathrm{N}_{2} /$ Ar ratio ranges from 96.3 for the crush release to 0.3 and 28.3 for the two thermal releases; the weighted Total Mole and Total Thermal ratio of 27.5 and 0.44 respectively. These ratios suggest large variations in $\mathrm{N}_{2}$ and $\mathrm{Ar}$, but do not (especially considering other gas compositions) imply the presence of atmospheric gas in the sample. The $\mathrm{N}_{2} / \mathrm{Ar}$ of atmosphere approximately 82 and of solubility in water approximately 38 . Helium is high at $214 \mathrm{ppm}$. Tapajós data plot in $\mathrm{N}_{2}-\mathrm{Ar}-\mathrm{He}$ space comparable to Tambo (Deyell., et.al. this volume).

In striking contrast to these results is the huge amount of $\mathrm{H}_{2}$ along with $\mathrm{CO}$, even though $\mathrm{CO}_{2} / \mathrm{CH}_{4}$ approximately 12.8 , and $\mathrm{H}_{2} \mathrm{~S} / \mathrm{SO}_{2}$ approximately 2.3 are normal and appear to be equilibrium ratios. Typical of many gas analyses of fluid inclusions in alunite, $\mathrm{H}_{2}$ is not in thermodynamic equilibrium with other gas species. Possible reasons for high $\mathrm{H}_{2}$ contents in alunite fluid inclusion gas are discussed in Landis and Rye (this volume).

\section{Noble gas data from step-heating extraction}

The results of $100^{\circ} \mathrm{C}$ increment, 60 minute duration step-heating release of $\mathrm{He}, \mathrm{Ne}$, and Ar from $200^{\circ}-700^{\circ} \mathrm{C}$ are presented and discussed below. Patterns of noble gas isotope release graphed with each temperature interval are used to demonstrate three major gas release sites: 1) fluid inclusion gas, 2) OH-site gas, and 3) gas retained to high temperature in alunite crystal structure. Major trends in gas release patterns are easily depicted in the series of plots presented and interpreted, even though data are limited and temperature steps of $100^{\circ} \mathrm{C}$ do not allow for extremely precise step resolution of trends. Some data are intrinsically diagnostic, e.g. mantle versus crustal sources, radiogenic or nucleogenic excess production, atmospheric contamination. We evaluate plots of specific ratios and multiple isotopes as indicators of processes that have affected noble gas retained in alunite over the past $1.87 \mathrm{Ga}$. Interpretative and speculative discussion is given along with each graphic analysis for brevity.

The helium, neon, and argon concentrations and isotopic compositions from $200^{\circ}-700^{\circ} \mathrm{C}$ step-heating gas release are reported in Table 4. Both concentration and appropriate ratios are calculated (moles/g and atomic ratios). Concentration Total is the sum of all gas released by isotopic species. Ratio Tolal is the ratio calculated from totals in concentration. The * notation 
indicates an atmospheric corrected isotope excess present in the system or sample.

Table 4. Noble Gas Isotope Concentrations and Ratios. Tapajos XI-16: IS. Nlunite

Concentration

\begin{tabular}{|c|c|c|c|c|c|c|c|c|}
\hline Temp. ${ }^{\circ} \mathrm{C}$ & $\begin{array}{c}\text { He } \\
\text { (molesig) }\end{array}$ & $\begin{array}{c}\text { 'He } \\
\text { (moles'g) }\end{array}$ & $\begin{array}{c}{ }^{20} \mathrm{Ne} \\
\text { moles/g }\end{array}$ & $\begin{array}{c}{ }^{21} \mathrm{Ne} \\
\text { molesigg }\end{array}$ & $\begin{array}{l}{ }^{22} \mathrm{Ne} \\
\text { moles/g }\end{array}$ & $\begin{array}{c}{ }^{3 r} \mathrm{Ar} \\
\text { (moles/g) }\end{array}$ & $\begin{array}{c}{ }^{31} \mathrm{Ar} \\
\text { (moles/g) }\end{array}$ & $\begin{array}{c}{ }^{\infty} \mathrm{Ar} \\
\text { (moles/g) }\end{array}$ \\
\hline 22.4 & $3.29 E-20$ & $1.81 \mathrm{E} \cdot 14$ & $2.53 E \cdot 14$ & $8.10 \mathrm{E} \cdot 17$ & $2.72 E \cdot 15$ & $4.98 \mathrm{E} \cdot 15$ & 0 & $3.01 \mathrm{E} \cdot 12$ \\
\hline 200 & $2.33 E \cdot 18$ & $1.58 \mathrm{E}-13$ & $6.13 E-14$ & $2.08 E-16$ & $6.90 E \cdot 15$ & $1.48 \mathrm{E}-14$ & $5.03 E=18$ & $9.33 \mathrm{E}-12$ \\
\hline 308 & $7.48 E-18$ & $2.77 \mathrm{E} \cdot 13$ & $5.87 E \cdot 15$ & $1.80 \mathrm{E}-17$ & $6.14 E \cdot 16$ & $1.81 \mathrm{E} \cdot 14$ & $3.41 \mathrm{E} \cdot 17$ & $1.06 \mathrm{E}-11$ \\
\hline 408 & $3.92 E \cdot 18$ & $5.29 E \cdot 13$ & $5.35 E-15$ & $1.65 \mathrm{E} \cdot 17$ & $5.53 E-16$ & $5.41 E \cdot 14$ & $3.46 E-15$ & $5.50 \mathrm{E} \cdot 11$ \\
\hline 500 & $9.08 \mathrm{E} \cdot 19$ & $2.87 E \cdot 12$ & $6.18 E \cdot 15$ & $3.20 \mathrm{E}-17$ & $6.69 E \cdot 16$ & 5.99E-14 & $2.14 E \cdot 13$ & 4.28E-09 \\
\hline 600 & $6.26 \mathrm{E}-18$ & 2. $33 \mathrm{E} \cdot 12$ & $2.80 E \cdot 14$ & $2.75 E-16$ & $3.32 E-15$ & $1.67 \mathrm{E} \cdot 13$ & $2.45 E-12$ & $1.62 E \cdot 08$ \\
\hline 700 & $1.42 \mathrm{E} \cdot 18$ & 4. $35 \mathrm{E} \cdot 12$ & $1.12 E \cdot 15$ & $4.45 \mathrm{E} \cdot 18$ & $1.33 \mathrm{E}-16$ & $1.18 \mathrm{E} \cdot 13$ & $4.47 \mathrm{E} \cdot 13$ & $5.45 E-09$ \\
\hline Total: & $2.24 \mathrm{E}-17$ & $1.05 \mathrm{E}-11$ & 1.33E-13 & $6.35 \mathrm{E} \cdot 16$ & $1.49 \mathrm{E} \cdot 14$ & $4.36 \mathrm{E} \cdot 13$ & $3.11 \mathrm{E} \cdot 12$ & $2.60 \mathrm{E} \cdot 08$ \\
\hline \multicolumn{9}{|l|}{ Ratio } \\
\hline Temp. ${ }^{\circ} \mathrm{C}$ & ${ }^{3} \mathrm{He} / \mathrm{He}$ & $R / R a$ & $\begin{array}{c}R / R a \\
\left(200^{\circ} \mathrm{C}\right)\end{array}$ & $\frac{{ }^{20} \mathrm{Ne}}{{ }^{22} \mathrm{Ne}}$ & $\frac{{ }^{21} \mathrm{Ne}}{{ }^{22} \mathrm{Ne}}$ & ${ }^{21} \mathrm{Ne}^{*}$ & ${ }^{22} \mathrm{Ne}^{*}$ & ${ }^{21} \mathrm{Ne}^{*}$ \\
\hline 22.4 & $1.82 E-06$ & 1.31 & $1=10.60$ & 9.3045 & 0.0298 & $5.53 E \cdot 18$ & $1.42 \mathrm{E}-16$ & 0.0390 \\
\hline 200 & $1.48 E=05$ & $10.66=$ & $2=10.69$ & 8.8771 & 0.0301 & $2.47 \mathrm{E}-17$ & 6.61E-16 & 0.0374 \\
\hline 308 & 2.70E-05 & 19.50 & $3=10.44$ & 9.5580 & 0.0292 & $4.46 \mathrm{E}-19$ & 1.62E-17 & 0.0276 \\
\hline 408 & 7.42E-06 & 5.36 & & 9.6614 & 0.0298 & $5.65 \mathrm{E} \cdot 19$ & 8.75E-18 & 0.0645 \\
\hline 500 & 3.17E-07 & 0.23 & & 9.2357 & 0.0479 & $1.36 \mathrm{E} \cdot 17$ & $3.96 \mathrm{E} \cdot 17$ & 0.3438 \\
\hline 600 & 2.68E-06 & 1.94 & & B. 4337 & 0.0828 & $1.91 \mathrm{E}-16$ & 4. $68 \mathrm{E}-16$ & 0.4088 \\
\hline 700 & $3.27 \mathrm{E}-07$ & 0.24 & & 8. 3685 & 0.0334 & $1.12 E-18$ & $1.97 \mathrm{E}-17$ & 0.0571 \\
\hline Total: & 2.12E-06 & 1.53 & & 8.9248 & 0.0425 & $2.37 E=16$ & $1.36 \mathrm{E}-15$ & 0.1753 \\
\hline \multicolumn{9}{|l|}{ Ratio } \\
\hline Temp. ${ }^{\circ} \mathrm{C}$ & ${ }^{30} \mathrm{Ar}$ & ${ }^{\frac{31}{46} \mathrm{Ar}}$ & $\frac{{ }^{3} \mathrm{He}}{{ }^{21} \mathrm{Ne}^{*}}$ & & & $\frac{\mathrm{He}}{{ }^{40} \mathrm{Ar}}$ & & \\
\hline 22.4 & 605 & 0.0000 & 3276 & & -06 & 0.0060 & & \\
\hline 200 & 629 & 0.0003 & 6379 & 2.6 & .06 & 0.0169 & & \\
\hline 308 & 584 & 0.0019 & 621303 & 4.2 & $=.08$ & 0.0263 & & \\
\hline 408 & 1017 & 0.0639 & 936881 & & .08 & 0.0096 & & \\
\hline 500 & 71443 & 3.5764 & 210546 & 3.1 & .09 & 0.0007 & & \\
\hline 600 & 96928 & 14.6707 & 12175 & 1.1 & -08 & 0.0001 & & \\
\hline 700 & 46323 & 3.8053 & 3874210 & 2.0 & $=-10$ & 0.0008 & & \\
\hline Total: & 59536 & 7.1344 & 44321 & 9.1 & -09 & 0.0004 & & \\
\hline
\end{tabular}

The three $200^{\circ} \mathrm{C}-60 \mathrm{~min}$. data are combined and recalculated, normalized to $60 \mathrm{~min}$. release time. In Table 4, the three sequential and isothermal extractions in the column labeled $\mathrm{R} / \mathrm{Ra}\left(200^{\circ} \mathrm{C}\right)$ range from $10.44-10.69$ with a weighted average of 10.66. Tapajós fluid inclusions contain a $3 \mathrm{He}$ enriched helium, unlike $\mathrm{R} / \mathrm{Ra}$ in other magmatic-hydrothermal alunite known to be only $\leq 10$ 's Ma age that exhibit a significant crustal component (Landis and Rye, this volume). Helium from these younger alunite samples range from 0.07 to 1.31 .

Initially, we were concerned that different rates of diffusion for ${ }^{3} \mathrm{He}$ versus ${ }^{4} \mathrm{He}$ might fractionate helium isotopes yielding an apparent $3 \mathrm{He}$ enrichment. However, as clear from the three sequential $200^{\circ} \mathrm{C}$ gas releases $=\mathrm{f}$ (time), and from helium thermally released from other alunite with a very different ${ }^{3} \mathrm{He} /{ }^{4} \mathrm{He}$, no isotopic fractionation occurs during release. To the extent helium isotopes do not fractionate with thermal release, other noble gas isotope abundance data almost certainly are not affected. We model diffusion rates below but conclude that significant isotopic fractionation does not occur with leakage along crystal domain boundaries and micro-22 fractures or volume diffusion from either fluid inclusions or from the alunite crystal structure (Trull and Kurz, 1999; Ozima and Podosek, 2002). 


\section{Helium and Argon Isotopes}

Isotopic composition of helium varies with temperature and these data can be used to indicate gas release/storage sites in the alunite. The clear separation of He isotopes with different maxima for ${ }^{3} \mathrm{He}$ and ${ }^{4} \mathrm{He}$ during the stepwise heating argues strongly that the helium is derived from multiple sites within alunite. Percent of total ${ }^{3} \mathrm{He}$ and ${ }^{4} \mathrm{He}$ gas released versus temperature is illustrated in Figure 2a. Low temperature release gas is significantly enriched in ${ }^{3} \mathrm{He}$. We believe this helium, like the active gas, to be released from the many submicron fluid inclusion sites which are almost totally degassed with $200^{\circ}-300^{\circ} \mathrm{C}$ heating. By the $300^{\circ}-408^{\circ} \mathrm{C}$ temperature interval, and clearly above dehydration of alunite $\left(500^{\circ} \mathrm{C}\right)$, helium is derived from the mineral structure, and increasing amounts of ${ }^{4} \mathrm{He}$ are observed. Figure $2 \mathrm{~b}$ compares $\mathrm{R} / \mathrm{Ra}$ to cumulative percent of total helium released with stepped increase in temperature. Included on this diagram is the $\mathrm{R} / \mathrm{Ra}$ ( $\mathrm{x} 10$ for scale) weighted by the percent of total helium release for each temperature step which sums to a total $\mathrm{R} / \mathrm{Ra}=1.53$ at $100 \%$. Helium reaches a maximum $\mathrm{R} / \mathrm{Ra}=$ 19.5 at $308^{\circ} \mathrm{C}$ with only $4.3 \%$ of the helium released, dropping to $\mathrm{R} / \mathrm{Ra}=5.36$ at $408^{\circ} \mathrm{C}$ and $9.3 \%$ of total helium. These data are consistent with the assertion that approximately $200^{\circ} \mathrm{C} \mathrm{He}$ is released mainly from fluid inclusion sites. The plateau between $408^{\circ} \mathrm{C}-500^{\circ} \mathrm{C}$ identifies the initial alunite dehydration with a large concomitant release of water and initial production of $\mathrm{H}_{2} \mathrm{SO}_{4}$. At $500^{\circ} \mathrm{C}$ and above, the $\mathrm{R} / \mathrm{Ra}=0.2$ to 2 and is dominated by high ${ }^{4} \mathrm{He}$ representing nearly $65 \%$ of helium released from the alunite.

The geologic setting of this alunite sample precludes any surface cosmogenic ${ }^{3} \mathrm{He}$ production. Further, release of very different helium isotope ratios with temperature from identifiable sites supports the contention that this alunite 1) has not been exposed to cosmogenic ${ }^{3} \mathrm{He}$ production, and 2) has not exchanged helium with isotopically different helium during eons of burial. Both these cases should yield more uniform temperature release patterns. Cumulative percent of total release of ${ }^{3} \mathrm{He},{ }^{4} \mathrm{He}$, and ${ }^{40} \mathrm{Ar}$ plotted versus temperature in Figure 2c, illustrate a very different release profile for the different isotopes of helium and argon. $94.8 \%$ of argon is released at $200^{\circ} \mathrm{C}$ and $95.7 \%$ by $308^{\circ} \mathrm{C}$. We suspect that argon released between crush and $308^{\circ} \mathrm{C}$ is argon in fluid inclusions with a consistent ${ }^{40} \mathrm{Ar} /{ }^{36} \mathrm{Ar}$ approximately 584-629. This is not argon released at higher temperature from the mineral structure with ${ }^{40} \mathrm{Ar} /{ }^{36} \mathrm{Ar}>9.6 \times 104$. Note that unlike helium, argon does not show a change in rate of release across the temperature interval of thermal destruction of structural $\mathrm{OH}$ in alunite, implying that: 1) high temperature released argon is more tightly retained in the $\mathrm{K}-\mathrm{SO}_{4}$ tetrahedral coordinated intervals of alunite (radiogenic ${ }^{40} \mathrm{Ar}$ ) than argon in fluid inclusion sites, and 2) these two argon retention sites in alunite are distinctly separate and do not exchange. 
Figuruc $2 \mathrm{a}$

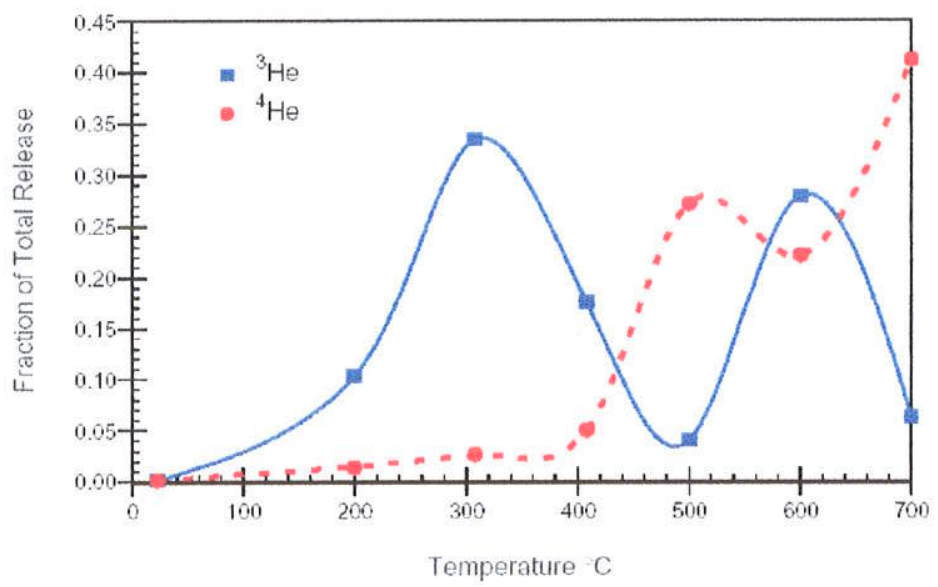

Figure 2b

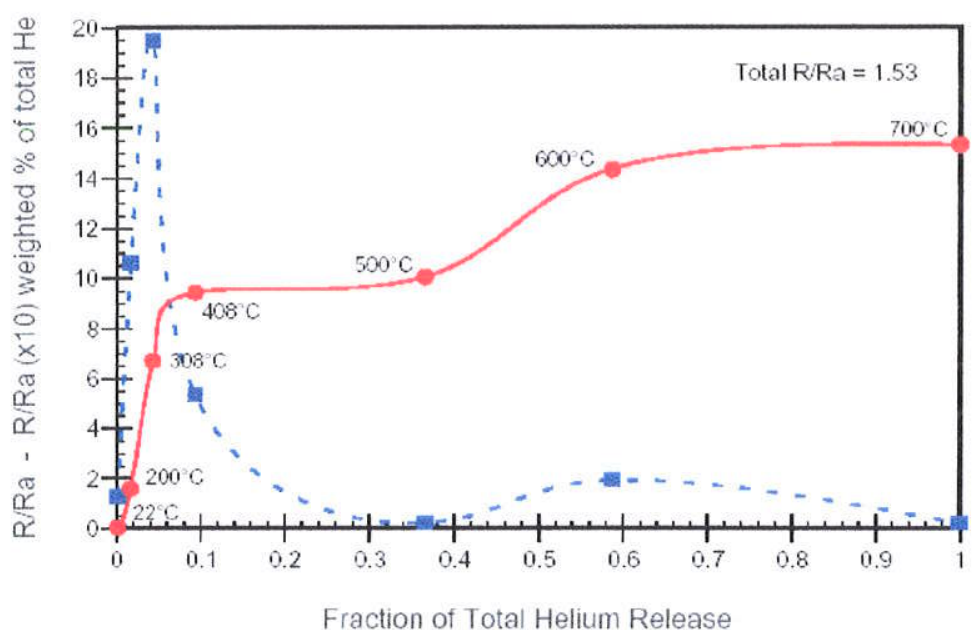

Fig̣ur $2 \mathrm{c}$

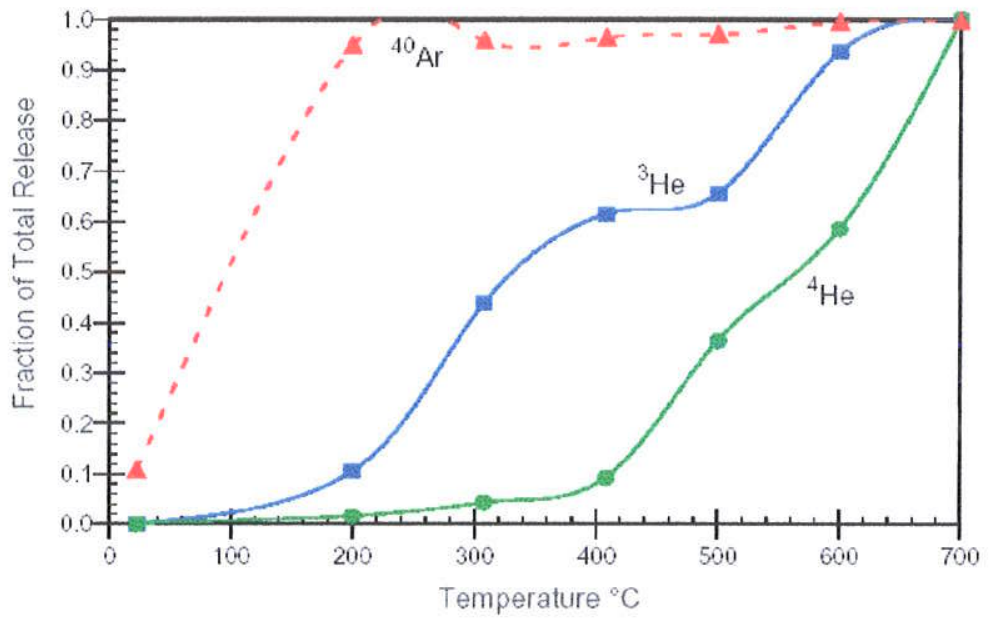

Figure 2. a. $3 \mathrm{He}$ and $4 \mathrm{He}$ temperature release patterns plotted as percent of total measured at temperature. Total $3 \mathrm{He}$ and $4 \mathrm{He}$ release are $2.24 \times 10-17$ and $1.05 \times 10-11$ moles $/ g$ respectively. $b . R / R a$ $(\mathrm{Ra}=3 \mathrm{He} / 4 \mathrm{He}$ of atmosphere $=1.384 \times 10-6)$ as squares and solid line, and $\mathrm{R} / \mathrm{Ra}(x 10)$ weighted as percent of total helium released as circles and dashed line, plotted against fraction of total helium released. . Temperatures of extraction label each point. $R / R a=1.53$ for total released helium. $c$. Fraction of total isotopic species released versus temperature step for $40 \mathrm{Ar}, 3 \mathrm{He}$, and $4 \mathrm{He}$. 
It is the argon released at high temperature from the breakdown of these tetrahedral layers, along with release of $\mathrm{SO}_{3}$ above $600{ }^{\circ} \mathrm{C}$, that is analyzed in ${ }^{40} \mathrm{Ar}-{ }^{39} \mathrm{Ar}$ age determinations.

During Ar-age spectra analysis, the sample is heated to $250^{\circ}-300^{\circ} \mathrm{C}$ and the fluid inclusion argon component is pumped away, and thus not included in age computations. The quantity of fluid inclusion argon is insignificant above approximately $300^{\circ} \mathrm{C}$. For $1.87 \mathrm{Ga}$ Tapajós alunite, the inherited Ar correction is not important given the very large amount of ${ }^{40} \mathrm{Ar}_{\text {rad. }}{ }^{4} \mathrm{He}$ release is uniform with temperature for approximately $90 \%$ of total $\mathrm{He}$, whereas ${ }^{3} \mathrm{He}$ shows several 'wiggles' which presumably represent discrete $3 \mathrm{He}$-enriched sites. We suspect these sites to be different size fluid inclusions and/or fluid inclusions with different gas/liquid content that decrepitate at different temperatures.

The contrast in noble gas chemistry between the low- and high- temperature gas retention sites is seen in Figure $3 a$ temperature release profiles of helium $(\mathrm{R} / \mathrm{Ra})$, argon $\left({ }^{40} \mathrm{Ar} /{ }^{36} \mathrm{Ar}\right)$, and ${ }^{4} \mathrm{He} /{ }^{40} \mathrm{Ar}$. Helium is a mixture of low temperature helium release from fluid inclusions with a ${ }^{3} \mathrm{He}$ enriched mantle component, and a high temperature release of radiogenic ${ }^{4} \mathrm{He}$, from the UTh and $\mathrm{K}$ decay (e.g. spallation induced), generated over $1.87 \mathrm{Ga}$ in the alunite. Two linear mixing lines are observed in Figure $3 b$ three isotope diagram of ${ }^{3} \mathrm{He} /{ }^{4} \mathrm{He}$ versus ${ }^{40} \mathrm{Ar} /{ }^{4} \mathrm{He}$ is evidence for mixing between these reservoirs within alunite.

The steep sloped mixing line is not heavily dependent upon ${ }^{40} \mathrm{Ar}$ production and represents mixing between originally trapped high $\mathrm{R} / \mathrm{Ra}$ helium and $\mathrm{R} / \mathrm{Ra}$ approximately lgroundwater-atmospheric helium in fluid inclusions of variable size, gas/liquid ratio, and helium retention or exchange. Mantle is characterized by ${ }^{4} \mathrm{He} /{ }^{40} \mathrm{Ar}$ approximately 10 , and the maximum observed in this alunite is ${ }^{4} \mathrm{He} /{ }^{40} \mathrm{Ar}$ approximately 0.026 . The maximum $\mathrm{R} / \mathrm{Ra}$ may be much higher were we to correct for radiogenic ${ }^{4} \mathrm{He}$ produced from U-Th decay in fluid inclusions. However, our probe analyses indicate that mineral U-Th concentrations are below reliable detection limits and must be no more than several 10's of ppm. Actinide concentration in inclusion fluids is unknown.

Neutron induced ${ }^{3} \mathrm{He}$ production from lithium $\left[6 \mathrm{Li}(\mathrm{n}, \alpha) 3 \mathrm{H} \square{ }^{*} 3 \mathrm{He}\right]$ is not likely to be significant with only trace amounts of lithium likely present in alunite. The second, low sloped line represents mixed amounts of radiogenic $\left({ }^{4} \mathrm{He}\right.$ and $\left.{ }^{40} \mathrm{Ar}\right)$ and possible spallogenic $\left({ }^{3} \mathrm{He}\right.$ and ${ }^{4} \mathrm{He}$ ) isotopes released with heating from the $\mathrm{K}-\mathrm{SO}_{4}$ alunite structural sites across the sulfate decomposition temperature.

We speculate that some small amount of spallation ${ }^{3} \mathrm{He}$ is present to account for the ${ }^{3} \mathrm{He}$ increase in $600^{\circ} \mathrm{C}$ release. Being deeply embedded in the tetrahedral sites, it is only released with temperature dependent destruction of the alunite structure (Ozima and Podosek, 2002). 
Figure 3a

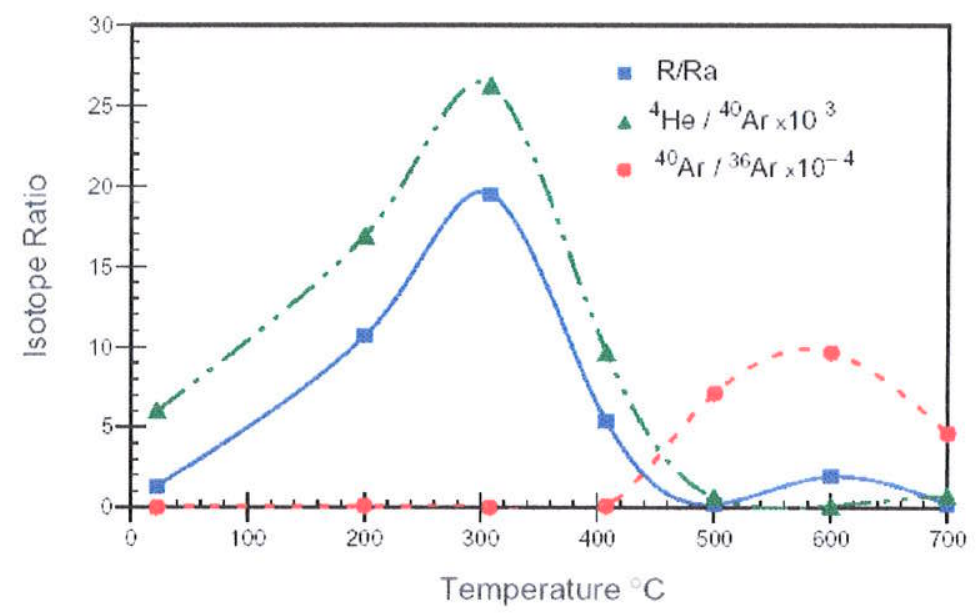

Figute 3b

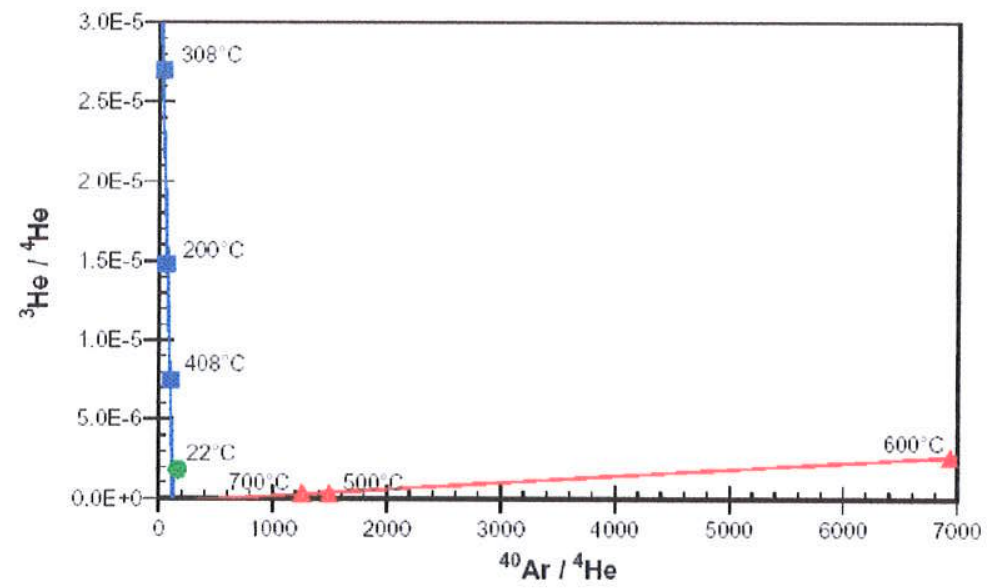

Figure 3c

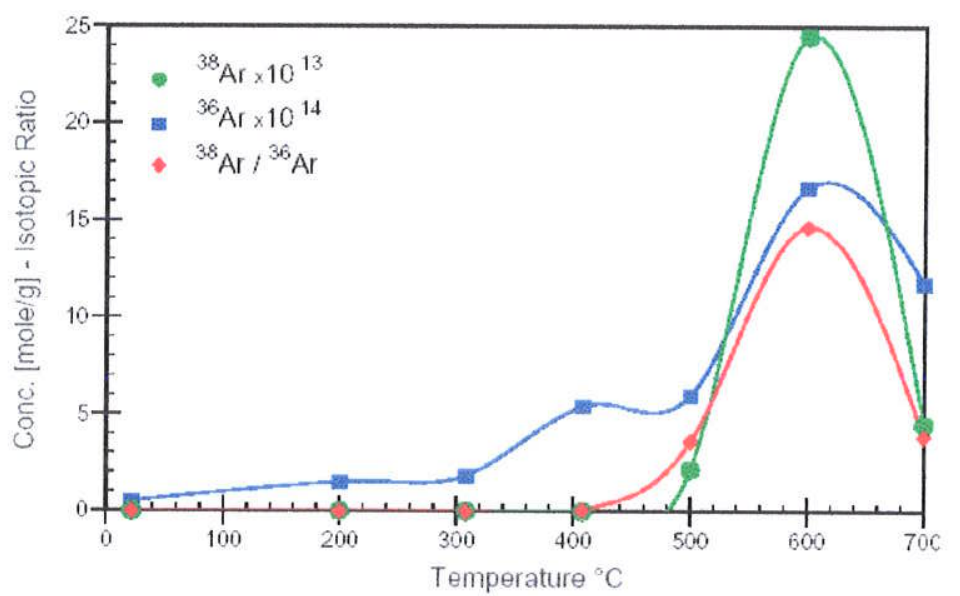

Figure 3. a. Isotopic Ratios versus temperature step for helium (R/Ra), ${ }^{4} H e{ }^{40} \mathrm{Ar}$ (x 103), and ${ }^{+0} \mathrm{Ar}{ }^{36} \mathrm{Ar}(x 10-4)$. Note that the later two ratios are multiplied by a scaling factor for illustration purposes. b. Three isotope plot showing two mixing lines in ${ }^{3} \mathrm{He}{ }^{4} \mathrm{He}$ versus ${ }^{40} \mathrm{Ar}{ }^{4} \mathrm{He}$ space as explained in the text. c. Concentration of ${ }^{38} \mathrm{Ar}$ (x1013) and ${ }^{36} \mathrm{Ar}$ (x1014) in moles/g versus temperature step, and corresponding ${ }^{38} \mathrm{Ar}{ }^{36} \mathrm{Ar}$ ratio clearly define the isotope specific site release differences for these normally conservative (constant) argon isotopes. Nuclear $(n, \gamma)$ and $(n, \alpha)$ reactions involving chlorine and potassium isotopes likely produce these differences as explained in the text. 
${ }^{40} \mathrm{Ar} /{ }^{36} \mathrm{Ar}$ is approximately 615 from fluid inclusions, which is vastly different from ${ }^{40} \mathrm{Ar} /{ }^{36} \mathrm{Ar}$ of approximately 97,000 of mineral structure retained radiogenic argon (40K decay). Were ${ }^{40} \mathrm{Ar}$ diffusively mobile over long periods of geologic time, fluid inclusion argon would have equilibrated with argon of the surrounding host mineral. Even with such an enormous contrast in Ar isotopic composition, this exchange is not evident. As observed from the ${ }^{4} \mathrm{He} /{ }^{40} \mathrm{Ar}$ trace (Fig.3a), maximum ${ }^{4} \mathrm{He}(\alpha)$ relative to ${ }^{40} \mathrm{Ar}$ occurs in the $200^{\circ}-300^{\circ} \mathrm{C}$ range.

Though approximately $95 \%$ of total helium is released at high temperature, dominantly as radiogenic ${ }^{4} \mathrm{He}$, the ${ }^{40} \mathrm{Ar}$ accumulated from decay of ${ }^{40} \mathrm{~K}$ in the tetrahedrally coordinated $\mathrm{K}-\mathrm{SO}_{4}$ site is more abundant. Clearly, the highly radiogenic ${ }^{40} \mathrm{Ar}$ only resides in the high temperaturerelease mineral structure site, and not in the structural $\mathrm{OH}$ site, or in fluid inclusions. An otherwise expected crustal production ratio of ${ }^{4} \mathrm{He} /{ }^{40} \mathrm{Ar}=4.9$ does not apply $\left({ }^{4} \mathrm{He} /{ }^{40} \mathrm{Ar}=3.11+\right.$ $0.738(\mathrm{Th} / \mathrm{U}) *(\mathrm{U} / \mathrm{K}) * 104:$ O’Nions and Ballentine, 1993) in the special enriched K-U-Th alunite mineral environment.

Both ${ }^{36} \mathrm{Ar}$ and ${ }^{38} \mathrm{Ar}$ generally are conservative in a crust-mantle environment, with a terrestrial abundance ratio of ${ }^{38} \mathrm{Ar} /{ }^{36} \mathrm{Ar}$ approximately 0.187 (McDougall and Harrison, 1999; Hiyagon, et.al., 1992; Honda, e.al., 1993; Niedermann, et.al., 1997; Poreda and Farley, 1992; Ozima and Igarashi, 2000). A plot of total ${ }^{36} \mathrm{Ar},{ }^{38} \mathrm{Ar}$, and ${ }^{38} \mathrm{Ar} /{ }^{36} \mathrm{Ar}$ versus temperature (Fig. 3c) shows ${ }^{38} \mathrm{Ar} /{ }^{36} \mathrm{Ar}=3.6-14.7$ in the $500^{\circ}-700^{\circ} \mathrm{C}$ release, whereas low temperature release $\left(22^{\circ}\right.$ $\left.408^{\circ} \mathrm{C}\right){ }^{38} \mathrm{Ar} /{ }^{36} \mathrm{Ar}=0.0-0.064$.

Fluid inclusion and mineral release argon below the alunite dehydration temperature interval are extremely enriched in ${ }^{36} \mathrm{Ar}$. Even argon released with the OH-site breakdown is dominantly ${ }^{36} \mathrm{Ar}$. Lacking an isotopic fractionation mechanism, we interpret this pattern as high temperature ${ }^{38} \mathrm{Ar}$ enrichment and low temperature ${ }^{36} \mathrm{Ar}$ enrichment by some nuclear process. Note that we observed no isobaric interference with argon isotopes from the presence of chlorine, sulfur, or organic molecules, given the thorough SAES gettering and cryogenic separation procedures used.)

We suggest the observed ${ }^{36} \mathrm{Ar}$ enrichment in fluid inclusions and hydrated crystal layers is from $(\mathrm{n}, \gamma)$ reactions with $\mathrm{Cl}$ and plentiful thermal neutrons. We do not know precisely the $\mathrm{Cl}$ content in this alunite (in OH-site), but several hundred ppm certainly is present (near the detection limit of microprobe) as reported in Table 2. Also, given a likely trace amount of actinide (U-Th) in the alunite hydrated layers and fluid inclusions with decay chain production of both fast $(>0.1 \mathrm{Mev})$ and slow to thermal neutrons, typical chlorine $(\mathrm{n}, \gamma)$ reactions are possible, e.g.; ${ }^{35} \mathrm{Cl}(\mathrm{n}, \gamma){ }^{36} \mathrm{Cl}(\beta-){ }^{36} \mathrm{Ar}$ and ${ }^{37} \mathrm{Cl}(\mathrm{n}, \gamma){ }^{38} \mathrm{Cl}(\beta-)$ 38Ar. In fact, the Q energies of these reactions are large and positive, such that only thermal neutrons are required for reactions to proceed. Note that none of the Tapajs alunite was exposed at the surface since formation $1.87 \mathrm{Ga}$ 
ago, and cosmogenic neutron production of these argon isotopes (Renne, et.al., 2001) is deemed not possible.

From measured thermal neutron capture cross sections, the ${ }^{36} \mathrm{Cl} /{ }^{38} \mathrm{Cl}$ (and therefore ${ }^{36} \mathrm{Ar} /{ }^{38} \mathrm{Ar}$ ) production ratio is about 316 (Roddick, 1983). At high temperatures $\left(500^{\circ}-700^{\circ} \mathrm{C}\right)$ sufficient to release argon from the $\mathrm{K}_{-} \mathrm{SO}_{4}$ tetrahedra within the alunite structure, the very large $38 \mathrm{Ar}$ enrichment likely is derived from the $41 \mathrm{~K}$ minor isotope 27 (6.7\% abundance) with slow to fast neutrons by ${ }^{41} \mathrm{~K}(\mathrm{n}, \alpha){ }^{38} \mathrm{Cl}(\beta-){ }^{38} \mathrm{Ar}$. This $(\mathrm{n}, \alpha)$ reaction also would contribute to the radiogenic $4 \mathrm{He}$ seen in the high temperature gas release. An additional pathway ${ }^{35} \mathrm{Cl}(\alpha, \mathrm{p}){ }^{38} \mathrm{Ar}$ is possible but energetically less likely.

Assuming that fluid inclusions contain modified original trapped argon, that atmosphere corrected excess ${ }^{36} \mathrm{Ar} *$ is all derived from the ${ }^{35} \mathrm{Cl}$ pathway (natural $\mathrm{n}-\gamma$ reaction in alunite), and correcting for $\mathrm{Cl}$ abundance, the affected chlorine concentration is approximately $37 \mathrm{ppt}$ (atomic). A total chlorine concentration cannot be calculated, but will be much more, given a small increase in ${ }^{38} \mathrm{Ar}$ from ${ }^{37} \mathrm{Cl}$ (1 in 316 chlorine atoms), and noting that only a small percentage of $\mathrm{Cl}$ atoms will be involved in such nuclear transformations. Probabilities for other nucleogenic production pathways are small because of associated large negative Q energies of reaction.

\section{Neon Isotopes}

The fluid inclusion, structural $\mathrm{OH}$, and high temperature gas sites are clearly defined in neon release patterns of Figure 4.

In Figure $4 \mathrm{a}$, the fraction of ${ }^{20} \mathrm{Ne},{ }^{21} \mathrm{Ne}$, and ${ }^{22} \mathrm{Ne}$ release is plotted against temperature, and illustrate the three major gas retention sites. Both ${ }^{20} \mathrm{Ne}$ and ${ }^{22} \mathrm{Ne}$ exhibit identical release from fluid inclusion and dehydration sites. At high temperature, slight ${ }^{22} \mathrm{Ne}^{*}$ excess (atmosphere corrected) is observed. As seen in Figure $4 b$, the fraction of excess ${ }^{22} \mathrm{Ne}$ and ${ }^{21} \mathrm{Ne}$ released by $200^{\circ} \mathrm{C}$ is $59.2 \%$ and $12.7 \%$ respectively. At $600^{\circ} \mathrm{C}$, essentially all of the neon is extracted from the alunite $(98.6 \%$ and $99.5 \%)$.

The ${ }^{21} \mathrm{Ne} /{ }^{22} \mathrm{Ne}=0.029-0.083$, and ${ }^{20} \mathrm{Ne} /{ }^{22} \mathrm{Ne}=8.37-9.66$. Atmospheric corrected excess ${ }^{21} \mathrm{Ne}^{*} /{ }^{22} \mathrm{Ne}^{*}=0.028-0.409$. For reference, ${ }^{21} \mathrm{Ne} /{ }^{22} \mathrm{Ne}=0.029\left(\right.$ atmosphere), ${ }^{21} \mathrm{Ne} /{ }^{22} \mathrm{Ne} \geq$ 0.070 (MORB), and ${ }^{21} \mathrm{Ne} /{ }^{22} \mathrm{Ne}$ approximately 0.47 (crust) (Kennedy, et.al., 1990; Ballentine, 1997; O’Nions and Ballentine, 1993). Lacking any evidence for incorporation of atmospheric gas in the alunite, we infer that neon is a mixture between mantle neon and nucleogenic neon. Average crustal ${ }^{21} \mathrm{Ne} /{ }^{22} \mathrm{Ne}$ approximately 0.47 , derived from nucleogenic production. In Figure $4 \mathrm{c}$, both ${ }^{21} \mathrm{Ne}^{*}$ and ${ }^{22} \mathrm{Ne}^{*}$ can be seen to define the separate fluid inclusion and alunite structural matrix sites. 
Figure ta

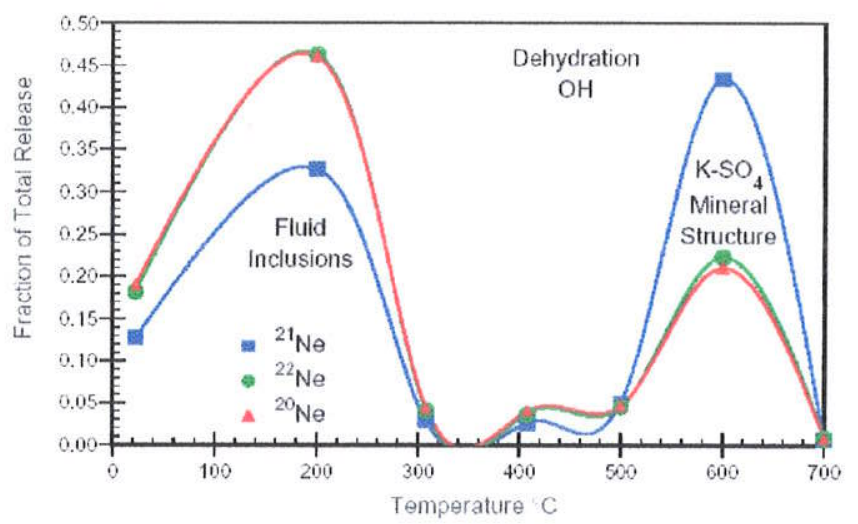

Figure fl

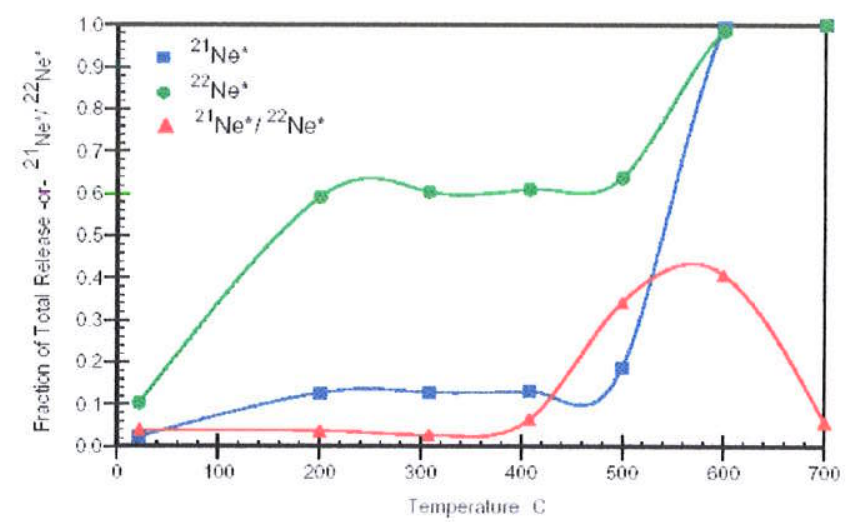

Figure ts

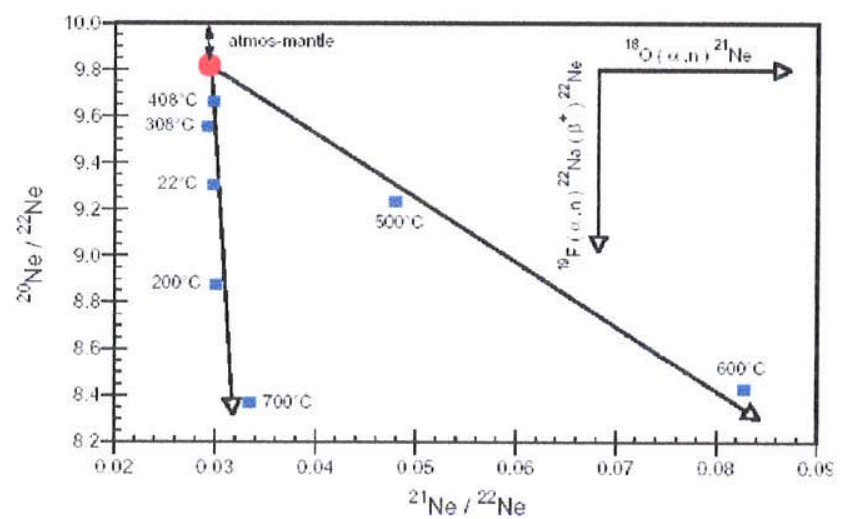

Figure 4. a. Fraction of total neon isotopic species released versus temperature step for $20 \mathrm{Ne}, 21 \mathrm{Ne}$. and $22 \mathrm{Ne}$. As seen in the previous helium and argon diagrams, neon clearly defines gas release from fluid inclusions, dehydration $\mathrm{OH}$ site, and $\mathrm{K}-\mathrm{SO} 4$ mineral structure site. Low temperature release of neon exhibits a nearly constant ratio of $20 \mathrm{Ne} / 22 \mathrm{Ne}$, and an increased amount of $22 \mathrm{Ne}$ at high temperature (lower $20 \mathrm{Ne} / 22 \mathrm{Ne}$ ). The ${ }^{2 l} \mathrm{Ne} e^{22} \mathrm{Ne}$ has increased from near atmospheric value (0.029) to approximately 0.083. b. Fraction of total neon isotope released versus temperature step for calculated ${ }^{21} \mathrm{Ne} *$ and ${ }^{22} \mathrm{Ne} *$ excess. The ${ }^{2 l} \mathrm{Ne} *{ }^{22} \mathrm{Ne} *$ ratio increased at high temperature steps through nucleogenic production within the alunite host mineral. $c .{ }^{20} \mathrm{Ne}{ }^{22} \mathrm{Ne}$ versus ${ }^{21} \mathrm{Ne}{ }^{22} \mathrm{Ne}$ three isotope plot illustrating the mixing of sites within alunite and the $(\alpha, n)$ nucleogenic reactions with fluorine and oxygen that differently characterize these sites. 
Additionally, ${ }^{21} \mathrm{Ne}^{*}$ dramatically increases preferentially to ${ }^{22} \mathrm{Ne}^{*}$ in the high temperature release from the latter site, giving rise to a peak in the ${ }^{21} \mathrm{Ne}^{*} /{ }^{22} \mathrm{Ne}^{*}$ ratio.

Note (fig.4b) that $59.2 \%$ of the ${ }^{22} \mathrm{Ne}^{*}$ and only $12.7 \%$ of ${ }^{21} \mathrm{Ne}^{*}$ is released at $200^{\circ} \mathrm{C}$. Significantly more neon is released only at $\geq 500^{\circ} \mathrm{C}$, liberating the remaining $36 \%$ of ${ }^{22} \mathrm{Ne}^{*}$ and $81 \%$ of ${ }^{21} \mathrm{Ne}^{*}$. The ${ }^{21} \mathrm{Ne} *{ }^{22} \mathrm{Ne}^{*}$ ratio maximum $\left(600^{\circ} \mathrm{C}\right)=0.41$.

Figure $4 \mathrm{c}$ illustrates the ${ }^{20} \mathrm{Ne} /{ }^{22} \mathrm{Ne}-{ }^{21} \mathrm{Ne} /{ }^{22} \mathrm{Ne}$ three isotope space with step-heating neon isotopic compositions. Neon isotopes appear to represent mixtures between mantle-atmosphere compositions with subsequent nucleogenic production of ${ }^{21} \mathrm{Ne}$ and ${ }^{22} \mathrm{Ne}$. The nucleogenic production slope is proportional to ${ }^{19} \mathrm{~F} /{ }^{18} \mathrm{O}$ ratio within the alunite. We assume that alpha generating sources are either in fluid inclusions, in the hydration planes within alunite, or uniformly distributed throughout the crystal structural matrix. Alpha emitters must be in proximity to the appropriate nuclear targets as typical $\alpha$ stopping distances are approximately $25-40 \mu$. By comparison to granitic rocks, the $\mathrm{n} / \alpha$ production ratio is approximately $2.5 \times 10-6$, making $(\alpha, n)$ nuclear production reactions most important (Morrison and Pine, 1954).

Radiogenic $\alpha$ particles are present in the $\mathrm{OH}$-sites, in fluid inclusions, and in the alunite structure, from U-Th decay, as well as spallation product $\alpha$ particles. Kennedy, et.al. (1990), estimate that approximately $97 \%$ of $21 \mathrm{Ne}^{*}$ is derived from oxygen, and $98 \%$ of ${ }^{22} \mathrm{Ne}^{*}$ from fluorine by the following reactons: ${ }^{18} \mathrm{O}(\alpha, \mathrm{n}){ }^{21} \mathrm{Ne}$ and ${ }^{19} \mathrm{~F}(\alpha, \mathrm{n}){ }^{22} \mathrm{Na}(\beta+){ }^{2} 2 \mathrm{Ne}$. We interpret our data to imply that fluorine $\left({ }^{19} \mathrm{~F}\right)$ resides both in fluid inclusions and substituted for $\mathrm{OH}-$, and that these sites contain a mixture of mantle and fluorine-derived nucleogenic neon. Neon retained to high temperature in alunite clearly is dominated by the ${ }^{18} \mathrm{O}(\alpha, \mathrm{n}) 21 \mathrm{Ne}$ reaction (figs. $\left.4 \mathrm{~b}, 4 \mathrm{c}\right)$. Neon trapped in fluid inclusions may have had a low initial ${ }^{20} \mathrm{Ne} /{ }^{22} \mathrm{Ne}$ from ${ }^{25} \mathrm{Mg}(\mathrm{n}, \alpha){ }^{22} \mathrm{Ne}$ contributions to the trapped fluids. But insitu $\mathrm{Mg}$ transformations within alunite can be ruled out.

Two additional plot analyses were considered, though plots are not included here: ${ }^{4} \mathrm{He} /{ }^{40} \mathrm{Ar}$ versus ${ }^{4} \mathrm{He}$ (cm3STP g-1) and ${ }^{21} \mathrm{Ne} *{ }^{22} \mathrm{Ne}$ vs ${ }^{4} \mathrm{He} /{ }^{22} \mathrm{Ne}$ (Ozima and Igarashi, 2000), to evaluate MORB versus OIB mantle components to the alunite gas content. In both evaluations, the data plot completely in the He-deficient OIB side of the ${ }^{21} \mathrm{Ne}^{*} /{ }^{4} \mathrm{He}$ production line and below the closed mantle ${ }^{4} \mathrm{He}-{ }^{40} \mathrm{Ar}$ system.

Further, the data separate into a low-temperature fluid inclusion release gas field and a field of high-temperature alunite crystal structure release. These data, compared to published MORB and OIB (and diamond) noble gas data (Ozima and Podosek, 2002), clearly indicate a less degassed Paleoproterozoic mantle source similar to OIB compositions trapped in the fluid inclusions in the $1.87 \mathrm{Ga}$ alunite, with radiogenic and nucleogenic modifications to noble gas isotopes retained in the alunite crystal domains.

The ${ }^{4} \mathrm{He} /{ }^{21} \mathrm{Ne} *$ ratio (Table 4 ) is significantly above the estimated crustal production of 
$9.96 \times 10-6$ (O’Nions and Ballentine, 1993) throughout the entire extraction steps from crush to $700^{\circ} \mathrm{C}$ thermal release. The large ratios imply significant radiogenic ${ }^{4} \mathrm{He}$ in the alunite, with noted increase across the interval of dehydration, and again at the final $700^{\circ} \mathrm{C}$ temperature step (interval of SO3 breakdown). We speculate that a significant portion of the trace U-Th in alunite must reside in the hydration $\mathrm{OH}$-sites, as well as within the tetrahedral-coordinated sulfate intervals. Both sites favor buildup of radiogenic $4 \mathrm{He}$ from $\mathrm{U}-\mathrm{Th}$ decay. The ${ }^{21} \mathrm{Ne}^{*} /{ }^{40} \mathrm{Ar}$ r ratio (Table 3), illustrates in situ production of these isotopes is dominated at low-temperature (fluid inclusion gas release) by nucleogenic ${ }^{21} \mathrm{Ne}$ and at high temperature (alunite structure) by radiogenic $40 \mathrm{Ar}$. Estimated crustal average ${ }^{21} \mathrm{Ne}^{*} /{ }^{40} \mathrm{Ar} *$ is approximately $4.94 \times 10-7$ (O'Nions and Ballentine, 1993).

Finally, the geochemical coherence of $\mathrm{U}$ and $\mathrm{K}$ in the upper mantle-crust creates a constant production ratio of ${ }^{4} \mathrm{He} /{ }^{40} \mathrm{Ar}$. Both ${ }^{21} \mathrm{Ne}^{*}$ and ${ }^{4} \mathrm{He}$ are derived from $\mathrm{U}$ and should have a constant ${ }^{21} \mathrm{Ne} * / 4 \mathrm{He}$ production ratio. Assuming the U-Th-K geochemical environment is constant, these production ratios should remain the same, and ${ }^{21} \mathrm{Ne} * /{ }^{4} \mathrm{He}$ versus ${ }^{4} \mathrm{He} /{ }^{40} \mathrm{Ar}$ can be used to evaluate a closed system condition within the alunite gas retention sites. This is illustrated in Figure 5.

The crush through $308^{\circ} \mathrm{C}$ release gas plots on a straight line defining constant production ratio closed system behavior for fluid inclusion gas. The high temperature release gas component plots in a completely different region of the diagram, indicating presumably the much different $\mathrm{U}(\mathrm{Th})-\mathrm{K}$ conditions of this retention site. Examination of the ${ }^{21} \mathrm{Ne}^{*} /{ }^{4} \mathrm{He}$ changes in Table 4, reveals increased neon $(\alpha, n)$ production in structural hydration layers and dominant ${ }^{4} \mathrm{He}$ production in the structural matrix as well as dominant ${ }^{40} \mathrm{Ar}$ production in the higher $\mathrm{T}$ site(s).

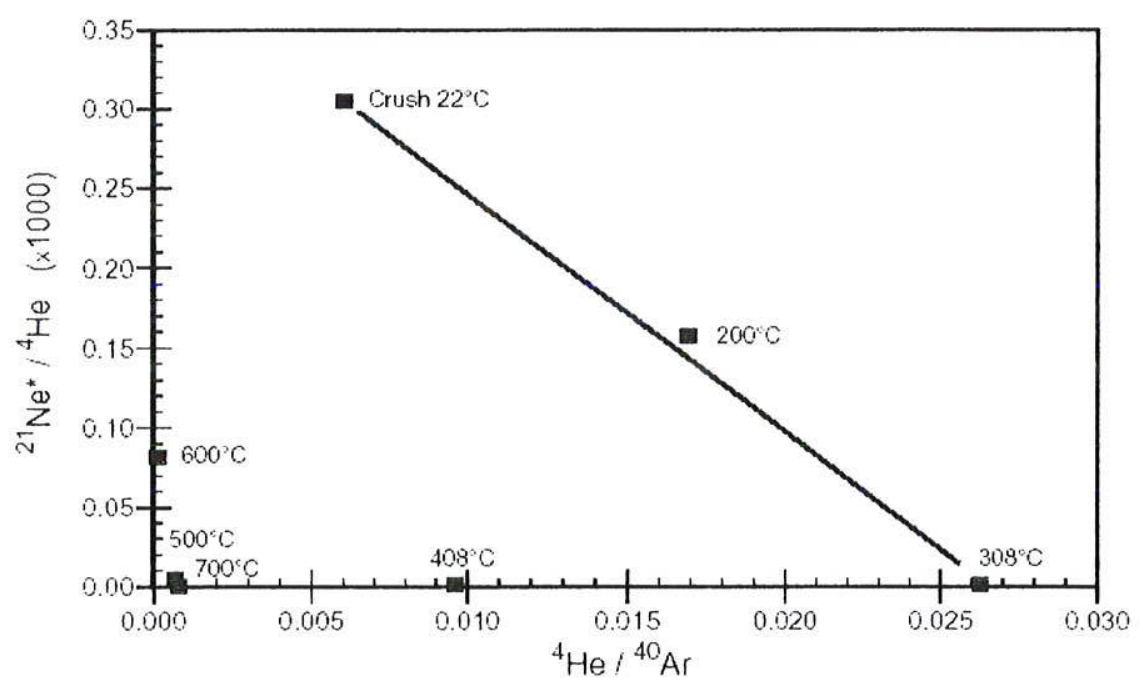

Figure 5. $21 \mathrm{Ne} / 4 \mathrm{He}$ versus $4 \mathrm{He} / 40 \mathrm{Ar}$ three isotope plot illustrating fluid inclusion population mixing as a separate gas release site, distinguished from higher temperature gas. These data define a constant UTh$K$ production ratio in a closed system for fluid inclusion gas. 


\section{Argon Geochronologic Data}

Argon thermal release data for ten alunites analyzed for argon age spectra (Juliani, et al., this volume) are given in Table 5 with additional data relevant to this study.

As described above in the methods section, these extractions and isotopic analyses were performed on a different vacuum furnace and mass spectrometer instrumentation in the argon geochronology lab. These samples previously had been irradiated in the USGS TRIGA reactor for the purpose of ${ }^{40} \mathrm{Ar} /{ }^{39} \mathrm{Ar}$ age determinations. We examined these data and the argon temperature release profiles for additional clues to argon retention and nucleogenic modifications in alunite.

Seven of these samples were analyzed under normal experimental conditions; i.e., after loading the samples onto the extraction system, the system was baked open to vacuum at $250^{\circ} \mathrm{C}$ overnight before gas processing and isotopic analysis. Thus any argon released at $<250^{\circ} \mathrm{C}$ was pumped away during bakeout and unavailable for isotopic analysis. In contrast, three samples, as indicated in Table 5, were irradiated individually in "breakseal" vials evacuated to $1 \times 10-8$ torr and sealed before irradiation for the purpose of collecting within that "breakseal" volume any ${ }^{39} \mathrm{Ar}$ and ${ }^{37} \mathrm{Ar}$ (irradiation-produced products of ${ }^{39} \mathrm{~K}$ and ${ }^{40} \mathrm{Ca}$, respectively) that may have been recoiled from the alunite samples during irradiation. After irradiation, these vials were attached to the extraction system, baked at $250^{\circ} \mathrm{C}$ overnight, and subsequently, the vacuum seal was opened on line, and the contents were analyzed for the argon isotopic compositions. In this case argon released from the samples during bakeout at $<250^{\circ} \mathrm{C}$ was not lost.

The results of the "breakseal" experiments indicate that less than 1 part in 500 39Ar and less than 1 part in 5000 40Ar were released into the vacuum during irradiation and subsequent heating during bakeout. Not listed in Table 5, is the large unquantified volumes of generally atmospheric ${ }^{40} \mathrm{Ar},{ }^{38} \mathrm{Ar}$, and ${ }^{36} \mathrm{Ar}$ released into the breakseal volume during the bakeout. This argon likely is identical to the $95 \%$ argon released from fluid inclusions during noble-gas experiments described above.

Just as ${ }^{38} \mathrm{Ar}$ and ${ }^{36} \mathrm{Ar}$ are produced from nucleogenic reaction in the natural environment, these isotopes are also produced from reactor irradiation. The reactions of interest are the same as those in the natural environment, i.e., ${ }^{35} \mathrm{Cl}(\mathrm{n}, \gamma){ }^{36} \mathrm{Cl}(\beta-){ }^{36} \mathrm{Ar}$ and ${ }^{37} \mathrm{Cl}(\mathrm{n}, \gamma){ }^{38} \mathrm{Cl}(\beta-){ }^{38} \mathrm{Ar}$. Abundances for the ${ }^{38} \mathrm{Ar}$ derived from $\mathrm{Cl}$ are indicated in Table 5; the samples were analyzed too quickly after irradiation to detect any ${ }^{36} \mathrm{Ar}$ produced from $\mathrm{Cl}$. These measurements, however, say nothing about the production of ${ }^{38} \mathrm{Ar}$ and ${ }^{36} \mathrm{Ar}$ from nucleogenic reactions over geologic time.

The implications of nucleogenic production of $36 \mathrm{Ar}$ from $\mathrm{Cl}$ over the life of the alunites are discussed below. Figure 6 is a plot of cumulative $\% 39 \mathrm{Ar}$ released from $0^{\circ}$ to $1000 \mathrm{OC}$ for all alunite samples. 
TABLE 5. "Ar $r^{34}$ Ar DATA FOR ALUNITES* FROM HIGH-SULFIDATION MINERALIZATION IN THE TAPAJOS GOLD PROVINCE, BRASIL

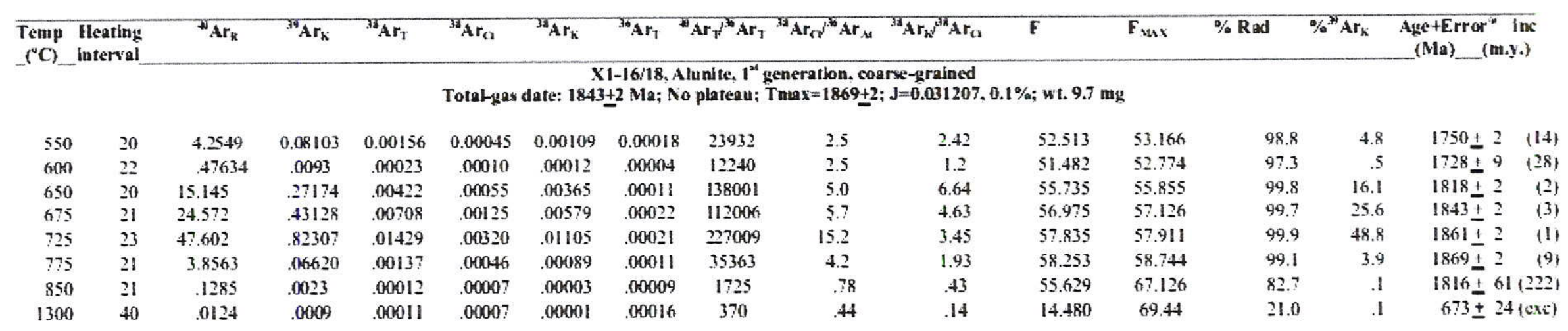

X1-16/G. Alunite, $1^{2 t}$ generation coarse-grained

Totahgas date: $1848+2 \mathrm{Mla}$; No plateau; Weighted-mean date $=1851 \pm 2 ; \mathrm{J}=0.031368 .0 .1 \%$; wt $10.3 \mathrm{mg}$

\begin{tabular}{|c|c|c|c|c|c|c|c|c|c|c|c|c|}
\hline 500 & 20 & 0.0429 & 0.0023 & 0.00043 & 0.000137 & 0.00003 & 0.00015 & 576.2 & 2.47 & 0.08 & 18.396 & 55.824 \\
\hline $5 \times 0$ & 40 & 55.375 & .97529 & .01444 & .00120 & .01310 & .00082 & 67838 & 1.46 & 10.9 & 56.778 & 57.026 \\
\hline $575^{4}$ & 20 & 19.291 & $.3386 ?$ & .00542 & .000084 & .00455 & .05015 & 128919 & 5.60 & 5.42 & 56.961 & 57.092 \\
\hline $\tan 0^{\circ}$ & 20 & 26.824 & .47098 & .00745 & .00110 & .00633 & .00014 & 191929 & 7.86 & 5.75 & 56.954 & 57.041 \\
\hline 625 " & 20 & 11.533 & .20219 & .00362 & .00090 & .00272 & .00003 & 384824 & 30.0 & 3.02 & 57.039 & 57.082 \\
\hline $6.50 \%$ & 24 & 46.561 & .81387 & .01425 & .00331 & .01093 & .00005 & 776404 & 66.2 & 3.30 & 57.209 & 57.227 \\
\hline $675^{*}$ & 21 & 7.2928 & .12750 & .00318 & .00146 & .00171 & .00003 & 243442 & 48.7 & .49 & 57.199 & 57.268 \\
\hline 700 & 20 & .6850 & .0134 & .000444 & .00025 & .00018 & .00004 & 17446 & 6.25 & .72 & $51.19 ?$ & 52.079 \\
\hline 800 & 20 & .1504 & .0030 & .00011 & .000066 & .00004 & $.00000 ?$ & 2426 & 0.86 & $6 ?$ & 50.868 & 57.780 \\
\hline
\end{tabular}

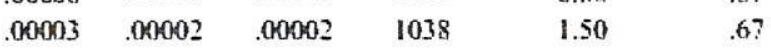

$10.516 \quad 25.112$

$\mathrm{X} 1-16 / \mathrm{F}$, Alunite, $2^{\text {es }}$ generation, coarse-grained

Total-gas date: $1835+4$ Ma; Plakeau date $=1853 \pm 3 ; \mathrm{J}=0.007257,0.12 \%$; w. $11.3 \mathrm{~mm}$

$\begin{array}{rrrrrrrrrrrrr}250 \mathrm{~b} & 915 & 0.0091 & 0.0017 & 0.00187 & 0.0013 & 0.00002 & 0.00297 & 298.6 & 0.45 & 0.02 & 5.467 & 534.19 \\ 300 & 10 & .0503 & .0008 & .00023 & .0001 & .00001 & .09064 & 372.5 & .16 & .01 & 65.695 & 310.94 \\ 400 & 11 & .0016 & .00006 & .00008 & .00001 & .00000 & .00036 & 303.8 & .03 & - & 25.015 & 1800.0 \\ 450 & 10 & .0012 & .00008 & .00008 & .00001 & .00000 & .00036 & 299.7 & .03 & -. & 15.930 & 1345.1 \\ 450 & 20 & .0180 & .0004 & .000010 & .00002 & .00000 & .00043 & 336.5 & .05 & . & 51.428 & 414.4 \\ 500 & 21 & .0628 & .0006 & .00013 & .00006 & .00001 & .00039 & 458.1 & .15 & .17 & 103.600 & 291.88 \\ 550 & 11 & .3015 & .0018 & .00014 & .00005 & .00002 & .00038 & 1089 & .13 & .40 & 169.901 & 233.80 \\ 550 & 21 & 1.1762 & .0059 & .00020 & .00005 & .00008 & .00043 & 3030 & .12 & 1.60 & 199.524 & 220.89 \\ 575 & 20 & 3.7452 & .0167 & .00936 & .00007 & .00022 & .00038 & 10152 & .18 & 3.14 & 224.314 & 230.99\end{array}$

\begin{tabular}{rrrr}
49.6 & 0.1 & \multicolumn{3}{c}{$822 \pm 46\{1000\}$} \\
99.5 & 33.1 & $1845 \pm 2$ & $\{5\}$ \\
99.8 & 11.5 & $1849 \pm 2$ & $\{2.5\}$ \\
99.8 & 16.0 & $1849 \pm 2$ & $\{1.5\}$ \\
99.9 & 6.9 & $1850 \pm 2$ & $11.5\}$ \\
99.9 & 27.6 & $1854 \pm 2$ & $\{0.5\}$ \\
99.9 & 4.3 & $1854 \pm 2$ & $\{1.5\}$ \\
98.2 & .5 & $1728 \pm 17$ & $\{19\}$ \\
88.5 & .1 & $1721 \pm 23$ & $\{144\}$ \\
72.3 & .0 & $514 \pm 6$ & $(534\}$
\end{tabular}

(2)

3.7452

$.0167 \quad .0000236$

$\begin{array}{llll}.00005 & .00008 & .00043 & 3030\end{array}$

.18 


\begin{tabular}{|c|c|c|c|c|c|c|c|c|c|c|c|c|c|c|c|c|}
\hline 600 & 20 & 21.728 & .09414 & .00182 & .00043 & .00125 & .00082 & 26794 & .52 & 2.91 & 230.789 & 233.37 & 98.9 & 10.4 & 177517 & $\{13\}$ \\
\hline 625 & 20 & 1.5509 & . MR679 & .00025 & .00008 & .00009 & .00047 & 3596 & .17 & 1.13 & 228.342 & 248.86 & 91.8 &.$?$ & 176312 & 1981 \\
\hline $650^{P}$ & 21.5 & 48.764 & .19753 & .00407 & .00127 & .00261 & .00106 & 463060 & 1.2 & 2.06 & 246.866 & 248.453 & 99.4 & 21.7 & 185212 & (7) \\
\hline $675^{P}$ & 21.5 & 71.107 & .28732 & .00495 & .00095 & .00380 & .00111 & $6435 ?$ & .86 & 4.00 & 247.485 & 248.616 & 99.5 & 31.6 & $1855 \pm 4$ & (5) \\
\hline $725^{\circ}$ & 23 & 71.918 & .29140 & .00563 & .00143 & .00386 & .00192 & 37753 & .75 & 2.70 & 246.803 & 248.740 & 99.2 & 32.0 & $1852 \pm 2$ & (9) \\
\hline 800 & 21 & .7200 & .0031 & .00029 & .00005 & .00004 & .00115 & 922.0 & .04 & .80 & 234.639 & 345.20 & 67.9 & .3 & $1794 \pm 1$ & $4(469\}$ \\
\hline 950 & 25 & .0217 & .0006 & .00019 & .00003 & $.0000 \mathrm{i}$ & .00087 & 320.6 & .03 & .33 & 39.131 & 506.88 & 7.8 & .1 & $451 \pm 5$ & (2333) \\
\hline 1200 & 20 & .0030 & $.0007 ?$ & .00019 & .00K0? & .00001 & .000961 & 300.3 & .11 & .14 & 4.146 & 251.08 & 1.7 & .1 & 5319 & $\{1818\}$ \\
\hline
\end{tabular}

FV3-1/16, Alunite, $1^{x}$ seneration, Ine-graimed; $1^{\text {x }}$ analyss

Total-gas date: $1820 \pm 11 \mathrm{Ma}$; P lateau date $=1834 \pm 17 ; \mathrm{J}=0.007545 .0 .12 \%$; wh $8.3 \mathrm{mg}$

\begin{tabular}{|c|c|c|c|c|c|c|c|c|c|c|c|c|c|c|c|c|}
\hline $250 \mathrm{~b}$ & 695 & -0.00005 & 0.000661 & 0.00105 & 0.00067 & 0.00001 & $0.0020 ?$ & 295.46 & 0.32 & 0.015 & -0.89 & 1000 & -0.1 & 0.2 & $-12 \perp 80$ & $(3882)$ \\
\hline 450 & 60 & .0051 & .0001 & .00004 & .00004 & .00000 & .00007 & 364.57 & .57 & nd & 39.67 & 198.2 & 19.9 & .0 & 472179 & $\{11 ? 8\}$ \\
\hline 525 & 24 & .0358 & .0002 & .00001 & .00001 & .00000 & .000066 & 903.83 & .17 & nd & 151.34 & 247.8 & 66.1 & .1 & $1374 \overline{1} 31$ & (527) \\
\hline 600 & 23 & 2.9703 & .0154 & .000003 & .000003 & .00020 & .000018 & 37415 & .38 & 6.67 & 193.43 & 194.9 & 99.2 & 5.0 & $1623 \pm 9$ & $\{8\}$ \\
\hline $675^{P}$ & 20 & 48.016 & .20660 & .000000 & .00000 & .00274 & .00052 & 92626 & nd & $\mathrm{ndil}$ & 232.41 & 233.1 & 99.7 & 67.9 & $1827 \pm 9$ & $\{3.5\}$ \\
\hline $700^{P}$ & 22.5 & 16.450 & .0694 & .00016 & .00016 & .00092 & .00008 & 205916 & 2.29 & 5.75 & 236.98 & 237.3 & 99.9 & 22.8 & $1850 \pm 15$ & $\{1.5\}$ \\
\hline $725^{\circ}$ & 21 & 2.1660 & .0091 & .001000 & .00000 & .00012 & .00009 & 24356 & $\mathrm{nd}$ & $\mathrm{nd}$ & 237.64 & 240.7 & 98.8 & 3.0 & $1853 \div 26$ & (15) \\
\hline 750 & 23.5 & .2368 & .0010 & .00002 & .00002 & .00001 & .00002 & 12116 & 1.0 & .5 & 227.81 & 233.4 & 97.7 & .3 & $1804 \pm 21$ & $\{28\}$ \\
\hline 800 & 24.5 & .3434 & 0017 & .00000 & .00000 & .00002 & .00010 & 3738.5 & nd & nid & 204.13 & 222.0 & 91.9 & .6 & 168211 & $\{93\}$ \\
\hline 950 & 20.5 & .0118 & .0004 & .00003 & .00003 & .00000 & .000015 & 558 & .60 & nd & 32.742 & 73.76 & 42.2 & .1 & $398 \pm 81$ & $\{400\}$ \\
\hline 1150 & 22 & .0250 & .0003 & .00002 & .00002 & .00000 & .000066 & 721.5 & .33 & nd & 76.036 & 129.4 & 57.7 & .1 & $818 \div 96$ & $\{411\}$ \\
\hline 1350 & 25.5 & .0419 & .0002 & .000001 & .00001 & .00000 & .00091 & 341.5 & .01 & nd & 243.96 & $18 \geq 8$ & 13.5 & .1 & $1883 \pm 30$ & $\{2978\}$ \\
\hline
\end{tabular}

FV3-1/16, Alunite. $1^{*}$ generation. fine-grained; 2 nd analysis

Total-gas date: $1808 \pm 2 \mathrm{Ma}$; Plateau datt $=1846 \pm 2 ; \mathrm{J}=0.031319,0.1 \%$; wt. $10.4 \mathrm{mg}$

500
550
575
$6000^{\mathrm{P}}$
$625^{\mathrm{P}}$
650
675
700
750
1000

$$
\begin{gathered}
11.063 \\
9.8095 \\
10.154 \\
53.307 \\
3.6651 \\
.5555 \\
.1151 \\
.1297 \\
.1248 \\
.146
\end{gathered}
$$

0.00403

00084000310

.18067
.18280

.00268

.00024

.000310

.00051 21989

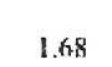

3.69

$47.973 \quad 48.614$

$.0140 ?$

.9571

.00121

$00143 \quad .01259$

$.00033 \quad .090806$

$\begin{array}{lll}.00008 & 122922 & 3.00\end{array}$

3.00
8.75

10.1

54.295
55.545 55.426

.0102

.00030

.00015

$\begin{array}{llll}.00086 & .00013 & 28484 & 2.54 \\ .000114 & .00003 & 18802 & 5.00 \\ .00003 & .00001 & 11936 & 4.00\end{array}$

.0025

.00010

$.00004 \quad .00003$

18002

4.00

.0034

.00015

.00008

00003

$00001 \quad 13385$

6.00

$00005 \quad 00006 \quad 518$

1.67

8.80

$56.867 \quad 55.609$

57.0692
54.500

$54.500 \quad 55.388$

$\$ 4.410 \quad 55.700$

$51.543 \quad 52.633$

$44.722 \quad 50.020$

$4.278 \quad 9.48$

$\begin{array}{rrrr}99.8 & 14.3 & 1655 \pm 2 & \{14\} \\ 99.9 & 11.2 & 1792 \pm 2 & \{3\} \\ 99.8 & 11.3 & 1818 \pm 2 & \{1\} \\ 99.0 & 58.0 & 1845 \pm 2 & \{2\} \\ 98.5 & 4.0 & 1850 \pm 2 & \{12\} \\ 96.5 & .6 & 1796 \pm 14 & \{19\} \\ 96.9 & .1 & 1794 \pm 13 & \{27\} \\ 89.2 & .2 & 1734 \pm 14 & \{23\} \\ 46.9 & .2 & 1580 \pm 15 & \{120\} \\ 99.8 & .2 & 227 \pm 42 & \{242\}\end{array}$

FV3-1/11, Alunite. $1^{\text {th }}$ generation. fon-yrai ned ceme nt

Total-yas date: $1842 \pm 2 \mathrm{Ma}$; Weighted-mean date $=1866^{7}+2 ; \mathrm{J}=0.029713 .0 .1 \%$; $1.11 .6 \mathrm{mte}$

$\begin{array}{llllll}0.00358 & 0.00008 & 0.00507 & 307.8 & 0.71 & 0.02\end{array}$

$0.1 \%$; w1. $11.6 \mathrm{mg}$
11.317 


\begin{tabular}{|c|c|c|c|c|c|c|c|c|c|c|c|c|c|c|c|c|}
\hline 500 & 21 & .36830 & .0093 & .00028 & .000007 & .00012 & $.0 K$. & 1062.8 & .14 & 1.71 & 39.785 & 55.091 & 72.2 & .2 & $1408 \pm 3$ & $\{341\}$ \\
\hline 550 & 21 & 6.0797 & .1549 & .00407 & .00179 & .00208 & .00102 & 6234 & 1.90 & 1.16 & 39.253 & 41.048 & 95.6 & 3.4 & $1395 \pm 12$ & $\{44\}$ \\
\hline 575 & 20 & 29.146 & .50582 & .00853 & .00163 & .00679 & .00057 & 51435 & $2.9 !$ & 4.16 & 57.622 & 57.949 & 99.4 & 11.0 & $1800 \div 2$ & (6) \\
\hline 600 & 20 & 4.0921 & .069004 & .00125 & .00020 & .004993 & .000067 & 6402 & .30 & 4.65 & 59.268 & 62.139 & 95.4 & 1.5 & $1832 \overline{1} 2$ & $\{55\}$ \\
\hline $625 \mathrm{WH}$ & 21 & 141.73 & 2.3243 & .03970 & .00824 & .031222 & .00129 & 110163 & 6.87 & 3.79 & 60.979 & 61.132 & 99.7 & 50.5 & 186512 & (3) \\
\hline $650 \mathrm{~W}$ & 20 & 2.8361 & .04676 & .00110 & .00018 & .00063 & .00166 & 2004 & .11 & 3.5 & 60.646 & 71.142 & 85.2 & 1.0 & $1859 \pm 2$ & $190\}$ \\
\hline $675 W$ & 20 & 88.623 & 1.4466 & .02512 & .00537 & .01943 & .00180 & 49534 & 3.03 & 3.62 & 61.266 & 61.627 & 99.4 & 31.4 & 187112 & (6) \\
\hline $700 \mathrm{~W}$ & 20 & 1.9878 & .0326 & .000074 & .00024 & .00044 & .00036 & 5819 & $6 ?$ & 1.83 & 60.880 & 64.142 & 94.9 & .7 & $1863 \pm 4$ & $\{60\}$ \\
\hline 725 & 20 & .1046 & .0021 & .00015 & .00003 & .00003 & .00053 & 493.1 & .06 & 1.0 & 49.810 & 124.4 & 40.0 & .0 & $1638 \pm 23$ & $\{1152\}$ \\
\hline 800 & 27.5 & $.0 \times 141$ & .00003 & .00019 & .00005 & .000000 & .01073 & 299.8 & .07 & $\mathrm{nd}$ & 14.399 & 758 & 1.9 & .0 & $643 \pm 43$ & $(\mathrm{cxc})$ \\
\hline 1200 & 20 & .0119 & .0007 & .00019 & .00005 & .00001 & 010074 & 296.9 & .07 & .20 & 2.773 & 324 & .9 & .0 & $143 \pm 23$ & (exe) \\
\hline
\end{tabular}

FV3-2/7, Alunite, $2^{\text {wa }}$ seneration, coarse-grainer

Tota-gas date: $1828+2 \mathrm{Mla}$; No platean; Tmax $=1857 \pm 2 ; \mathrm{J}=0.031300,0.1 \% ;$ wt. $11.3 \mathrm{mg}$

$\begin{array}{cccccc}0.00017 & 0.00032 & 0.00003 & 0.00015 & 985.6 & 2.13 \\ .00415 & .00063 & .00349 & .00019 & 69954 & 3.32 \\ .01514 & .00020 & .01493 & .00002 & 3135584 & 20 \\ .01255 & .00118 & .01132 & .00020 & 241031 & 5.90 \\ .00099 & .00014 & .00084 & .00005 & 71709 & 2.80 \\ .000994 & .00013 & .00080 & .00008 & 45265 & 1.62 \\ .00016 & .00005 & .00010 & .00007 & 6183 & .71 \\ .00010 & .00008 & .00002 & .00002 & 1724 & 4.00\end{array}$

0.094
5.54
74.6
9.59
6.00
6.15
2.00

44.70

63.88

$13.234 \quad .25955$

$62.696 \quad 1.11194$

48.138

1.11194
84323

3.5697

.0623

3.4360 .05975

.00010

.0000

Fv3-1/25. Alunite. $2^{\text {es }}$ peneration, coarse-grained

Tota-gus date: $1842 \pm 2 \mathrm{Ma}$; Platcau date $=1858+2 ; \mathrm{J} \approx 0.031310 .0 .1 \%$; w $.9 .9 \mathrm{mg}$

$\begin{array}{cccc}500 & 22 & 0.0437 & 0.0011 \\ 550 & 20 & 1.5847 & .03564 \\ 575 & 38.5 & 35.587 & .63959 \\ 600 & 20 & 10.867 & .19055 \\ 625 & 20.5 & .2147 & .0038 \\ 650^{\circ} & 20 & 17.616 & .30732 \\ 6755^{\circ} & 23 & 64.373 & 1.1186 \\ 700^{\circ} & 23 & 2.456 & .04256 \\ 750 & 23 & .2786 & .0051 \\ 1000 & 20 & .0745 & .0020\end{array}$

0.00040
.00076
.00903
.00262
.000099
.00461
.01740
.00072
.00015
.00013

$\begin{array}{ccccc}0.00035 & 0.00002 & 0.00019 & 529.8 & 3.89 \\ .00027 & .00048 & .00007 & 22959 & 3.86 \\ .00040 & .00859 & .00018 & 198031 & 2.22 \\ .00005 & .00256 & .000064 & 181446 & .83 \\ .000044 & .00005 & .000102 & 10992 & 2.00 \\ .00048 & .00413 & .000055 & 352682 & 9.60 \\ .00237 & .01502 & .00007 & 920049 & 39.5 \\ .00014 & .00057 & .00005 & 49424 & 2.80 \\ .00007 & .00007 & .00011 & 2827 & .64 \\ .00009 & .00003 & .00009 & 1110 & 1.00\end{array}$

0.06
1.78
21.5
51.2
1.25
8.60
6.34
4.07
1.00
.33

$\begin{array}{ll}38.790 & 88.39 \\ 44.466 & 45.044 \\ 55.641 & 55.724 \\ 57.030 & 57.123 \\ 56.550 & 58.060 \\ 57.323 & 57.370 \\ 57.549 & 57.565 \\ 57.709 & 58.053 \\ 54.701 & 61.131 \\ 37.237 & 50.522\end{array}$

69.4
99.6
99.9
99.9
99.6
99.3
95.0
84.2

$1579 \pm 29 \quad\{403\}$ $172113-151$ $\begin{array}{ll}1849 \pm 2 & (0.5)\end{array}$ $1853 \pm 5 \quad(5)$ $1857 \pm 2$ (8) $1771 \pm 10 \quad\{56\}$ $932191 \quad 11441$

FV3-1/12. Alunite, $3^{\text {rd }}$ generation, fine-graine d; sheared

Totalgas date: $1712+2 \mathrm{Ma}$; No plateau; Tmax $=1805+2 ; \mathrm{J}=0.030540,0.1 \%$; wt. $9.6 \mathrm{mg}$

$\begin{array}{ccccccccccccc}450 & 26 & 0.0196 & 0.0009 & 0.00010 & 0.00006 & 0.00001 & 0.00016 & 411 & 0.38 & 0.17 & 22.635 & 76.90 \\ 525 & 20 & .0334 & .0014 & .00008 & .00005 & .00002 & .00008 & 7245 & .62 & .40 & 23.750 & 40.71\end{array}$
76.90 59

$\begin{array}{rrlr}43.4 & 0.0 & 1434 \pm 33 & \{959\} \\ 98.6 & 1.5 & 1574 \pm 3 & \{13\} \\ 99.8 & 27.3 & 1820 \pm 2 & \{1.5\} \\ 99.8 & 8.1 & 1848 \pm 2 & \{2\} \\ 97.7 & .2 & 1838 \pm 16 & \{31\} \\ 99.9 & 13.1 & 1854 \pm 3 & \{1\} \\ 99.9 & 47.4 & 1859 \pm 2 & \{0.3\} \\ 99.4 & 1.8 & 1862 \pm 4 & 17\} \\ 89.6 & .2 & 1800 \pm 13 & \{129\} \\ 74.5 & .1 & 1394 \pm 16 & \{317\}\end{array}$

\title{
52
} 0334

(1)

\begin{abstract}
$.0005 \quad .00002 \quad .00000 \quad 7245$
\end{abstract}




\begin{tabular}{|c|c|c|c|c|c|c|c|c|c|c|c|c|c|c|c|c|}
\hline 6066 & 22 & 1.2173 & .040009 & .000661 & .000006 & .00054 & .000044 & 30772 & 150 & 9.0 & 30.363 & 30.658 & 98.9 & 1.9 & $1884 \pm 1$ & (8) \\
\hline 625 & 20 & 32.469 & 67332 & .00932 & .00027 & .00904 & .000007 & 464224 & 3.86 & 33.5 & 48.222 & 48.252 & 99.9 & 32.7 & $1633 i 2$ & (1) \\
\hline 650 & 21 & 66.445 & 1.2228 & .01693 & .00046 & .01642 & .00025 & 2661114 & 1.92 & 35.7 & 54.339 & 54.397 & 99.9 & 59.4 & $1765 \pm 2$ & iㅏ \\
\hline 675 & 20 & 4.0219 & .07140 & .00100 & .000003 & .00096 & $.06000 ?$ & 57749 & .43 & 32.0 & 56.328 & 56.618 & 99.5 & 3.5 & 180512 & (6) \\
\hline 725 & 23 & 2.1886 & 03902 & .00061 & .00008 & .00052 & .00005 & 44079 & 1.60 & 6.5 & 56.088 & $56.46 ?$ & 99.3 & 1.9 & $1800 \pm 2$ & (8) \\
\hline 800 & 20.5 & .3920 & .0074 & .00021 & .000009 & .00010 & .00011 & 3861 & .82 & 1.11 & 52.580 & 56.976 & 92.3 & .4 & $1728 \pm ?$ & $(90)$ \\
\hline 1200 & 20 & .0160 & .0036 & .00020 & .00013 & .00005 & .00010 & 4375 & 1.44 & .38 & 4.482 & 11.937 & 36.6 & .2 & $231 \pm 9$ & $\{329\}$ \\
\hline
\end{tabular}

FV3-3/3. Alunite. $1^{\text {2t }}$ generation. Rne-grained

Total-gas date: $99.4+0.4 \mathrm{Ma}$; Wehghted-mean date $=51.3+0.1 ; \mathrm{J}=0.031170 .0 .1 \% ;$ wt. $11.9 \mathrm{mg}$

\begin{tabular}{|c|c|c|c|c|c|c|c|c|c|c|c|c|c|c|c|c|}
\hline 400 & 21.5 & 0.0023 & 0.0005 & 0.00016 & 0.00014 & 0.00001 & $0.0000 ?$ & 309.7 & 2.0 & 0.071 & 4.655 & 46.826 & 10.4 & 0.0 & $244 \pm 62$ & $\mid 1380\}$ \\
\hline 450 & 22 & .0334 & .0059 & .00040 & .00029 & .00008 & .00021 & 461 & 1.4 & .276 & 5.658 & 16.198 & 34.5 & .2 & $293 \pm 15$ & (444) \\
\hline 500 & 19.5 & .0505 & .0182 & .00040 & .00014 & .00024 & .00005 & 1311 & 2.8 & 1.71 & 2.781 & 3.595 & 77.0 & .7 & $150 \pm 12$ & $\mid 42\}$ \\
\hline 525 & 20 & .10659 & .08247 & .00118 & .00006 & .00111 & .00006 & 2107 & 1.0 & 18.5 & 1.293 & 1.507 & 84.3 & 3.0 & 7112 & $\{12\}$ \\
\hline 550 & 26.5 & .46165 & .47654 & .00624 & nd & .00640 & .000009 & 5471 & bdd & bd & .969 & 1.080 & 93.8 & 17.5 & $53.7 \pm 0.1$ & $\{6\}$ \\
\hline $575 \mathrm{~W}$ & 20 & .50682 & .54896 & .00724 & nid & .00737 & .00004 & 13075 & bud & bd & .923 & .945 & 96.9 & 20.1 & $51.2 \pm 0.1$ & (1) \\
\hline $600 \mathrm{bH}$ & 20 & 66374 & .71565 & .00950 & nd & .00961 & .00003 & 22670 & bd & hid & .927 & .940 & 97.6 & 26.2 & $51.4 \pm 0.1$ & $(0.7)$ \\
\hline 625 & 33 & 1.0437 & .82427 & .01101 & nd & $.0110 ?$ & .000009 & 11984 & bd & bd & 1.266 & 1.298 & 96.8 & 30.2 & $69.8 \pm 0.3$ & $\{2\}$ \\
\hline 650 & 21 & .0992 & .0073 & .00015 & .00004 & .00010 & .000044 & $275 ?$ & 1.0 & 2.50 & 13.559 & 15.182 & 89.9 & .3 & $636 \pm 3$ & (63) \\
\hline 700 & 21 & .3797 & $.0 ! 10$ & .00026 & .00010 & .00015 & .00003 & 12991 & 3.3 & 1.50 & 34.611 & 35.418 & 97.4 & .4 & $1320 \pm 7$ & $\{22\}$ \\
\hline $1000 ?$ & 21.5 & $1.6 ! 38$ & .03995 & .00090 & .00033 & .00054 & $.0001 ?$ & 9798 & 1.9 & 1.64 & 40.399 & 41.652 & 92.3 & 1.5 & $1470 \pm 2$ & $(31)$ \\
\hline
\end{tabular}

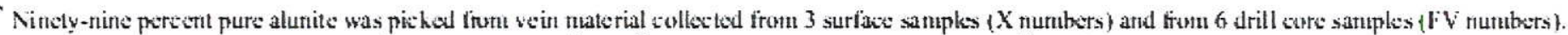

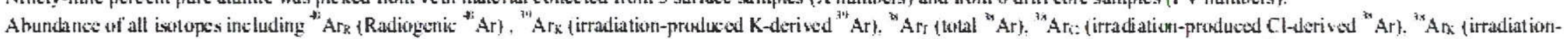

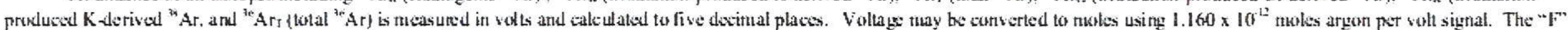

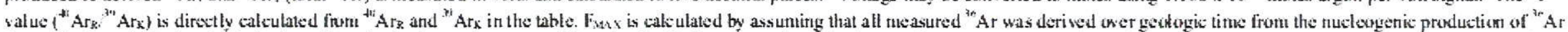

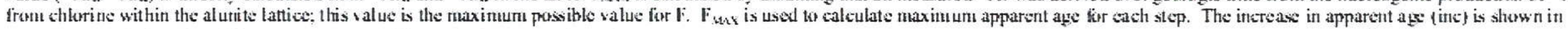

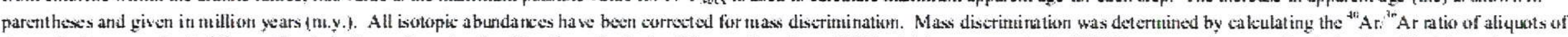

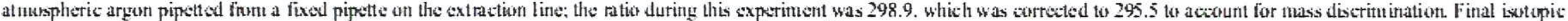

abundances were corrected for all interfering isotopes of argon including atmopheric arten. "Ar and "Ar. which are produced during irradiation, are radivactive and their abundances were corrected for radicactive decay. Abundances of interfering isotopes from $\mathrm{K}$ and $\mathrm{Ca}_{4}$ were calculated from reactor production rat ins deternined by irradiating and analyzing pure $\mathrm{CaF}_{2}$ and $\mathrm{K}_{2} \mathrm{SO}_{4}$; the $\mathrm{K}_{2} \mathrm{SO}_{4}$ was

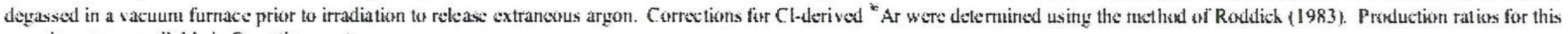
experituent are arailable in Snew (in press).

"Apparent ages of each fraction include the error in J salue $\{0.1 \%)$, which was calculated front the reproducibility of splits of the argon from several standards. The standard for this experintent is hornblende MMhb-1 (Samson and Alexander. 1987), and K-Ar age - 523.1 2.6 Ma (age revevaluated by Renne et al. 1998). Apparent ages were cakeulated using decay constants of Steiger and Jäger

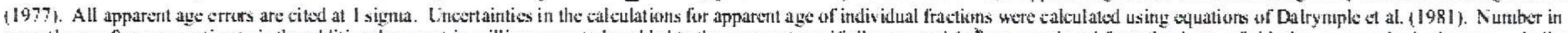

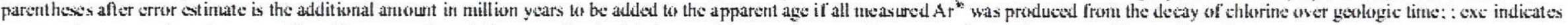

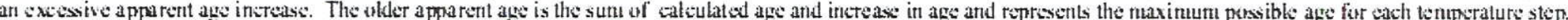

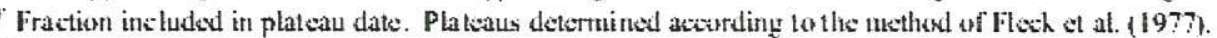

"F rastion included in weighted-mean date.

nd Betens detection limit 


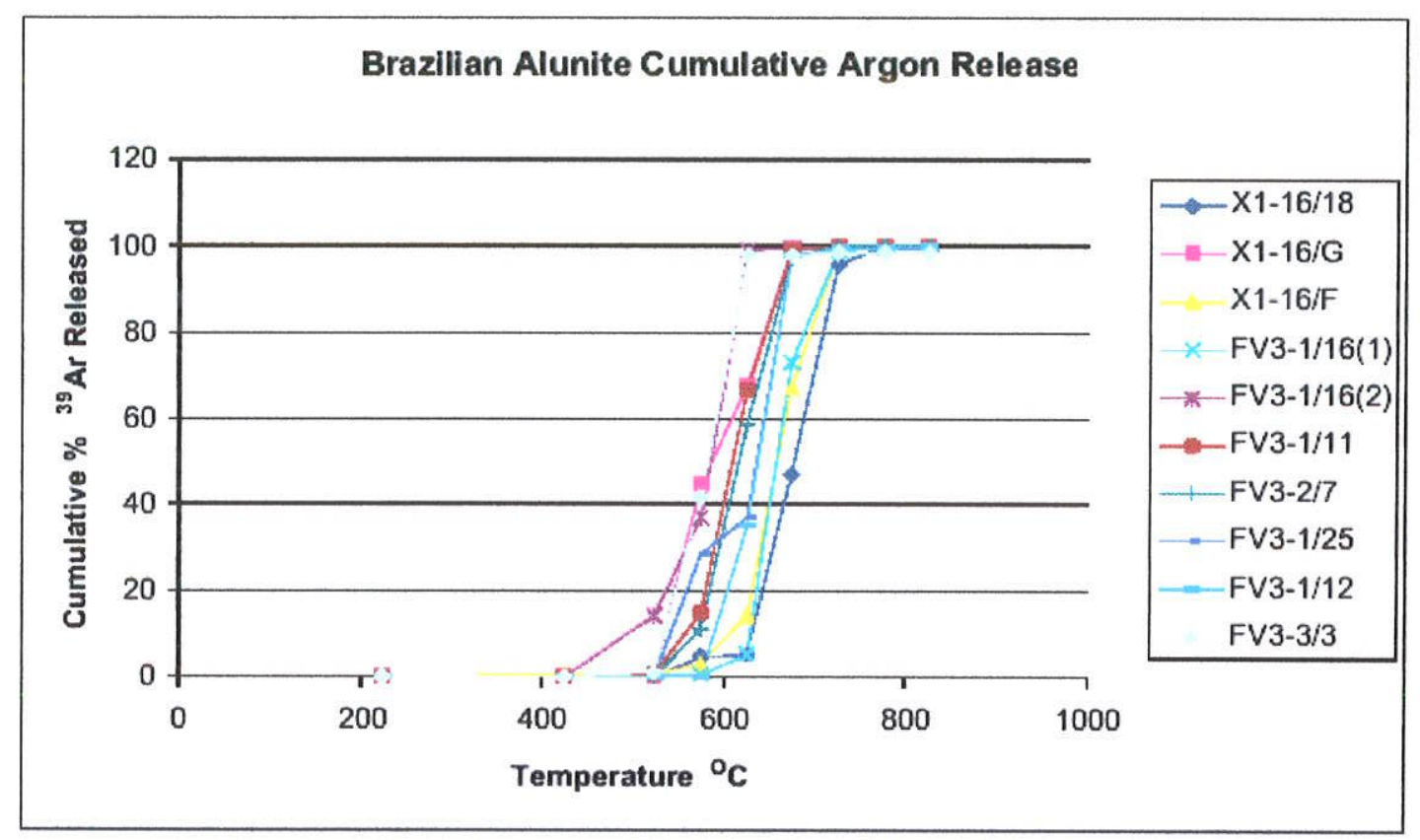

Figure 6. Cumulative percent 39Ar released form all alunite samples. More than $99 \%$ of the argon is released between 525 and $7250 C$.

As shown in Table 5, the majority of all argon is released from the samples within a small part of this range. In fact in all cases, $>99 \%$ of the argon isotopes are released between $525^{\circ}$ and $725^{\circ} \mathrm{C}$ regardless of compositional (Table 2) or textural (Figure 1) variation.

For all samples $>95 \%$ of the argon is released over a $125^{\circ} \mathrm{C}$ temperature range within the 525 and $725^{\circ} \mathrm{C}$ window. It was not uncommon for $40 \%$ or more ${ }^{39} \mathrm{Ar}$ to be released in a single $25^{\circ} \mathrm{C}$ temperature step. Because alunite undergoes $\mathrm{OH}$ - loss below $500^{\circ} \mathrm{C}$ and $\mathrm{K}_{-} \mathrm{SO}_{4}$ structural breakdown above $600^{\circ} \mathrm{C}$, it is likely that the argon release patterns indicate direct association of radiogenic and reactor-produced argon with the $\mathrm{K}-\mathrm{SO}_{4}$ sites. It is surprising that little or no argon is released during dehydroxylation. A composite ${ }^{40} \mathrm{Ar} /{ }^{39} \mathrm{Ar}$ age-spectrum plot in Figure 7 includes age spectra for 8 of the samples.

All eight samples show apparent 40Ar loss, exhibited by a stepping up in apparent age from left to right on the diagram. The amount of apparent argon loss is greatest for a sample of sheared alunite (FV3-1/12). The other seven samples exhibit $<<1 \%$ to a few percent of apparent argon loss and five of these samples exhibit plateaus or near plateaus with apparent ages ranging from $1846+2(1 \sigma)$ Ma to $1867+2 \mathrm{Ma}$. Although many of these plateau ages are distinct, there is no clear age relationship to alunite generation (Juliani et al., this volume). In fact 1st generation alunites FV3-1/16 and FV3-1/11 exhibit the two extreme ages of 1846 and $1867 \mathrm{Ma}$, respectively.

Though Juliani et al. (this volume) note that hydrothermal events producing later generations of alunite exhibiting crosscutting and replacement textures did not seem to alter the earlier formed alunite chemistry, perhaps some minor amount of radiogenic argon was lost. 


\section{Alunites - Tapajós Gold Province}

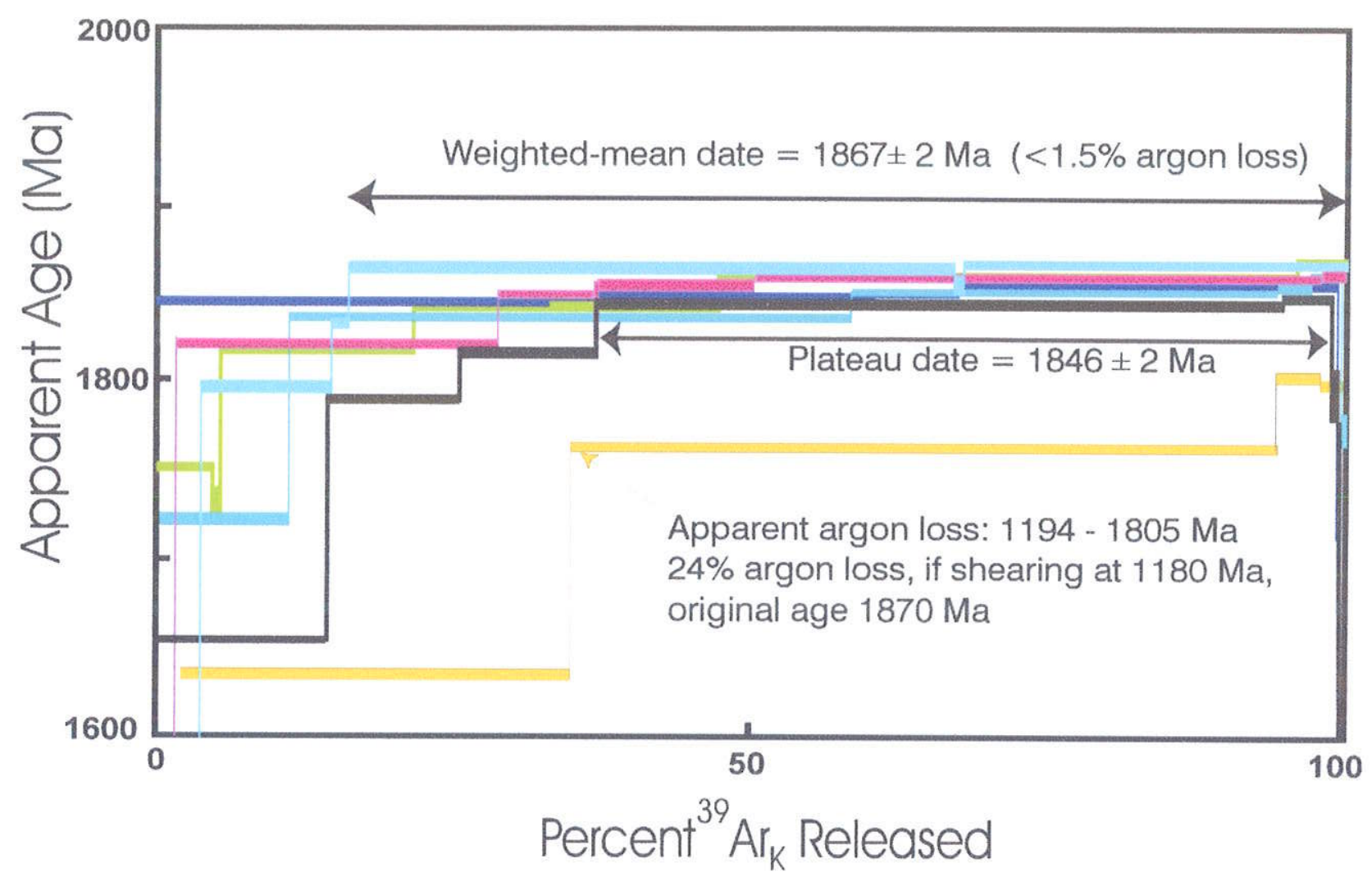

Figure 7. Composite 40Ar/39Ar age-spectrum diagram including spectra for 8 of 10 analyzed alunites. Seven of these give apparent ages ranging between 1846+2 (1 $\sigma$ ) Ma and 1867+2 Ma. Younger age spectrum exhibiting significant apparent argon loss is for a sheared alunite.

The composite ${ }^{40} \mathrm{Ar} /{ }^{39} \mathrm{Ar}$ age-spectrum diagram (Figure 8) shows the spectra of two different and separately analyzed samples of the same FV3-1/16. One gave a plateau date of $1834+17$ Ma defined by $95.7 \%$ of the released ${ }^{39} \mathrm{Ar}$; the other gave a plateau date of $1845+2 \mathrm{Ma}$ defined by $62 \%$ of the released ${ }^{39}$ Ar. These dates are identical within analytical error. However, the analyses reveal differences that are important for understanding the effects of different analytical procedures. The apparent age with the larger error represents the original sample used to determine if apparently Precambrian alunite could retain radiogenic argon over its geologic history. Before this analysis the oldest published alunite date was $62 \mathrm{Ma}$ (Bird and others, 1990). Anticipating that Precambrian alunite would not retain radiogenic argon, the first alunite sample was irradiated in the Denver TRIGA reactor for only 30 hours at $1 \mathrm{MW}$. The result of this short period of irradiation is an $\left.{ }^{40} \mathrm{Ar}_{\mathrm{R}}\right|^{39} \mathrm{Ar}_{\mathrm{K}}$ of $\sim 240$. For a sample size of $8 \mathrm{mg}$ in our system, the ${ }^{39} \mathrm{Ar}_{\mathrm{K}}$ abundances were too small to give optimal statistics.

Additionally, this sample was degassed in a manner in which nearly $75 \%$ of the ${ }^{39} \mathrm{Ar}$ was released in the $675^{\circ} \mathrm{C}$ step. However, this reconnaissance experiment was encouraging and justified study of additional alunite samples as well as a request to Caetano Juliani for additional material from the original sample. For the second experiment, all but one sample was irradiated 
for 129 hours at $1 \mathrm{MW}$ resulting in ${ }^{40} \mathrm{Ar}_{\mathrm{R}} /{ }^{39} \mathrm{Ar}_{\mathrm{K}}$ ratios of $\sim 60$ and resultant ${ }^{39} \mathrm{Ar}_{\mathrm{K}}$ abundances that produced analytical errors improved by an order of magnitude. In the second experiment on FV3-1/16, not only are errors smaller but also the degassing schedule was done in more detail.

The effects of these differences are shown clearly in Figure 8. However, there are differences between the two experiments that are not fully reconciled by differences in experimental technique. In the second experiment the majority of the ${ }^{39} \mathrm{Ar}$ was released at or before $600^{\circ} \mathrm{C}$; in the first, argon was released between 675 and $700^{\circ} \mathrm{C}$.

\section{Alunite FV3-01/16 - Tapajós Gold Province}

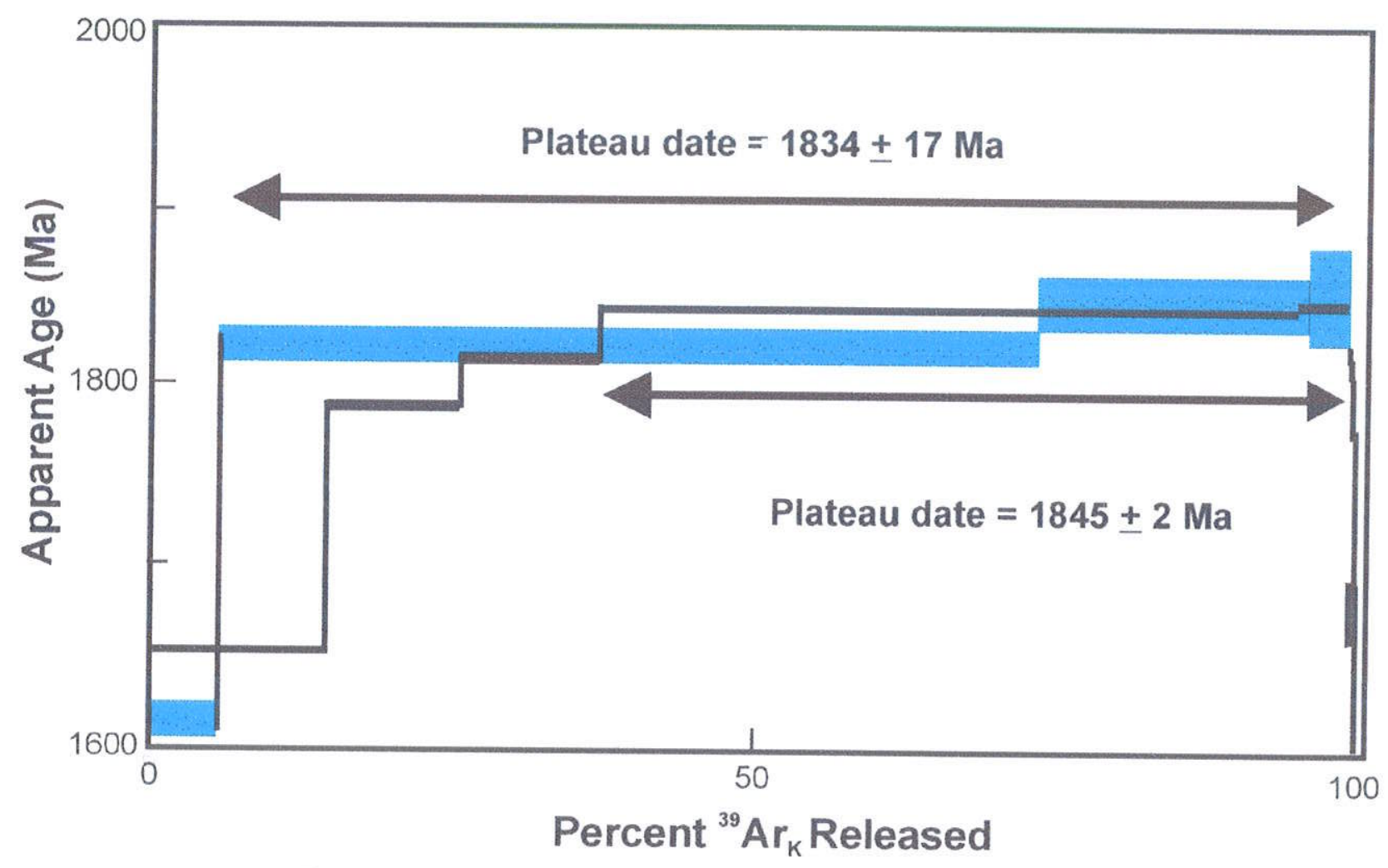

Figure 8. Composite ${ }^{40} \mathrm{Ar}^{39}$ Ar age-spectrum diagram showing spectra for two analyses of alunite sample FV3-1/16. Error envelops are indicated by solid or shaded patterns defining width of age bars. First analysis of FV3-1/16 done on a sample irradiated for 30 hours at IMW in USGS TRIGA reactor. Low ${ }^{39} \mathrm{Ar}_{K}$ production leads to larger errors than those for second analysis for FV3-1/16 irradiated for 129 hours at IMW. Different character of the release spectra is due in part to different heating schedule and possible to different sample composition.

The cause of this is unclear but one possibility is the selected samples actually represent alunite of slightly different composition and grain size existing in the same sample. Juliani et al. (this volume) discuss withinsample variably of alunite showing convincingly that compositional and textural variation is common in single samples. We note that in calculating diffusion parameters below, and in examining the temperature release profiles, the first analyzed FV3-1/16 alunite fits with the HTG, whereas the second analyzed sample of FV3-1/16 alunite exhibits properties characteristic of the LTG alunite. The two splits of FV3-1/16 alunite (B1) appear to be 
different. As discussed above, natural nucleogenic reaction on $\mathrm{Cl}(35 \mathrm{Cl}(\mathrm{n}, \gamma) 36 \mathrm{Cl}(\beta-) 36 \mathrm{Ar})$ can produce a significant amount of 36Ar within the alunite over geologic time.

In the typical ${ }^{40} \mathrm{Ar} /{ }^{39} \mathrm{Ar}$ age reduction program, such as we use to reduce argon isotopic data to apparent age, it is assumed that all non-reactor-produced ${ }^{36} \mathrm{Ar}$, i.e., ${ }^{36} \mathrm{Ar}$ that is not produced by nuclear reactions on $\mathrm{Cl}$ or $\mathrm{Ca}$ during irradiation, is atmospheric. The amount of atmospheric ${ }^{36} \mathrm{Ar}$ calculated is used to correct out atmospheric ${ }^{40} \mathrm{Ar}$. If some of the ${ }^{36} \mathrm{Ar}$ attributed to atmospheric contribution were in fact produced by nucleogenic production of ${ }^{36} \mathrm{Ar}$ from $\mathrm{Cl}$ over geologic time, the applied atmospheric correction would be too large. In Table 5, FMAX has been calculated, assuming as a maximum upper end member, that all ${ }^{36} \mathrm{Ar}$ that would normally be attributed to atmospheric argon correction was in fact produced by $\mathrm{Cl}$ nucleogenic reaction. This FMAX is used to calculate an age correction shown in parentheses at the end of each row. In some cases the age increase is significant. However, for most radiogenic fractions the age increase is one to five million years and essentially insignificant in the calculated age of each sample.

One sample in Table 5 (sample FV3-3/3) yielded an apparent age of 51.3+0.1 Ma (Figure 9), confirmed by isochron analysis (Juliani et al., this volume). This sample also yielded sulfur isotopic composition indicative of a supergene origin. This sample was collected from drill core within the bounds of all samples and is in no way unique in geologic setting. The presence of this sample within the limits of the magmatic hydrothermal system indicates that hydrothermal processes affected parts of the system without clear macroscopic effects on magmatichydrothermal alunite.

Supergene Alunite - Tapajós Gold Province

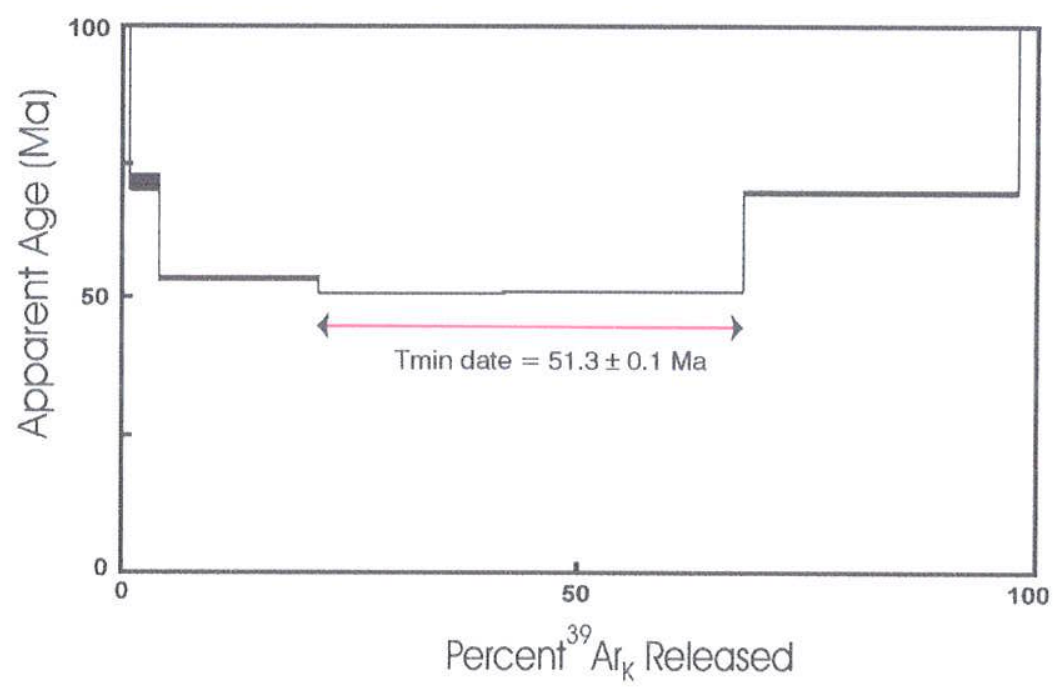

Figure 9. ${ }^{40} \mathrm{Ar}{ }^{39} \mathrm{Ar}$ age-spectrum for supergene alunite. Presence of excess argon indicated by shaddleshaped age spectrum. Apparent age of supergene alunite formation is $51.3+0.1$ Ma indicated by two overlapping temperature steps. Isochron for this sample, shown in Juliani et al. (this volume). confirms this apparent age. 


\section{Diffusion Models}

We use data from alunite step-heating gas release coupled with geochemical framework interpretation presented above to model diffusion parameters and argon and helium retention within alunite. Were the gas in question uniformly distributed, or approximately so, and if simple volume diffusion process were operational in releasing gas from the alunite, an Arrhenius plot $(\log (\mathrm{D})$ vs $1 / \mathrm{T})$ of the data might define diffusion activation energy and $\log (\mathrm{D})$ as a $f$ (temperature). The calculation requires that 1) the phase remain stable throughout the extraction experiment (strictly true for radiogenic ${ }^{40} \mathrm{Ar}$ above $500^{\circ} \mathrm{C}$, but not for ${ }^{4} \mathrm{He}$ ), 2) the initial distribution of gas be uniformly distributed (again not necessarily a good assumption except for ${ }^{40} \mathrm{Ar}$ ), 3) alunite crystal shape conforms to an approximation with the selected (spherical) diffusion equation, and 4) it is possible to determine the effective diffusion length (radius). As mentioned above, volume diffusion (characterized by length parameter) is the limiting step, with surface diffusion along crystal boundaries and major cleavage or fractures proceeding rapidly once a gas molecule reaches the outer edge of a crystal. We did not model other species $\left({ }^{3} \mathrm{He}\right.$ and neon isotopes), because only ${ }^{4} \mathrm{He}$ and ${ }^{40} \mathrm{Ar}$ showed smooth release curves as $f$ (time) with bulk of gas released near or above the dehydration temperature, and therefore best approximating the above criteria.

Neon isotopes theoretically should behave much like argon. We initially examined ${ }^{3} \mathrm{He}$ for comparison to ${ }^{4} \mathrm{He}$, because of concern for possible isotopic diffusion fractionation yielding apparent high ${ }^{3} \mathrm{He} /{ }^{4} \mathrm{He}$ with helium release from alunite at low $\left(200^{\circ} \mathrm{C}\right)$ temperature. We demonstrated this not to be the case (Table 4: $200^{\circ} \mathrm{C}$ helium data) with three successive 60 minute extractions at the same temperature. Theoretically, ${ }^{3} \mathrm{He}$ diffusion parameters should be at most only approximately $8 \%$ more rapid than ${ }^{4} \mathrm{He}$; e.g., isotopic partitioning $=f(\mathrm{~m}-0.5)$ and for a mass difference äm, the äm/m fraction is small fraction (largest for ${ }^{3} \mathrm{He}-{ }^{4} \mathrm{He}$ compared to other isotope masses) as applied in the energy term yielding a proportional theoretical difference in diffusion of $1-0.25(a ̈ \mathrm{~m} / \mathrm{m})$ or 0.9167 . Thus we should not expect large isotopic fractionation of ${ }^{3} \mathrm{He}$ from ${ }^{4} \mathrm{He}$ via diffusion out of alunite sites. We conclude that the measured helium ${ }^{3} \mathrm{He} /{ }^{4} \mathrm{He}$ release is real, and that variation in ${ }^{3} \mathrm{He}$ release is due to inhomogeneous site specific compositions (Figure 2c) compared to ${ }^{4} \mathrm{He}$.

We utilize the expression for a sphere to calculate the fractional loss of a gas species $(f)$ as a function of Dt/r2 (Fechtig and Kalbitzer, 1966; McDougall and Harrison, 1999). The model calculations are very sensitive to the radius (assumed $=10 \mu$ as in Figure 1) as the dimensional parameter for volume diffusion. The Arrhenius plot for ${ }^{3} \mathrm{He}$ and ${ }^{4} \mathrm{He}$ behavior is illustrated in Figure 10. 


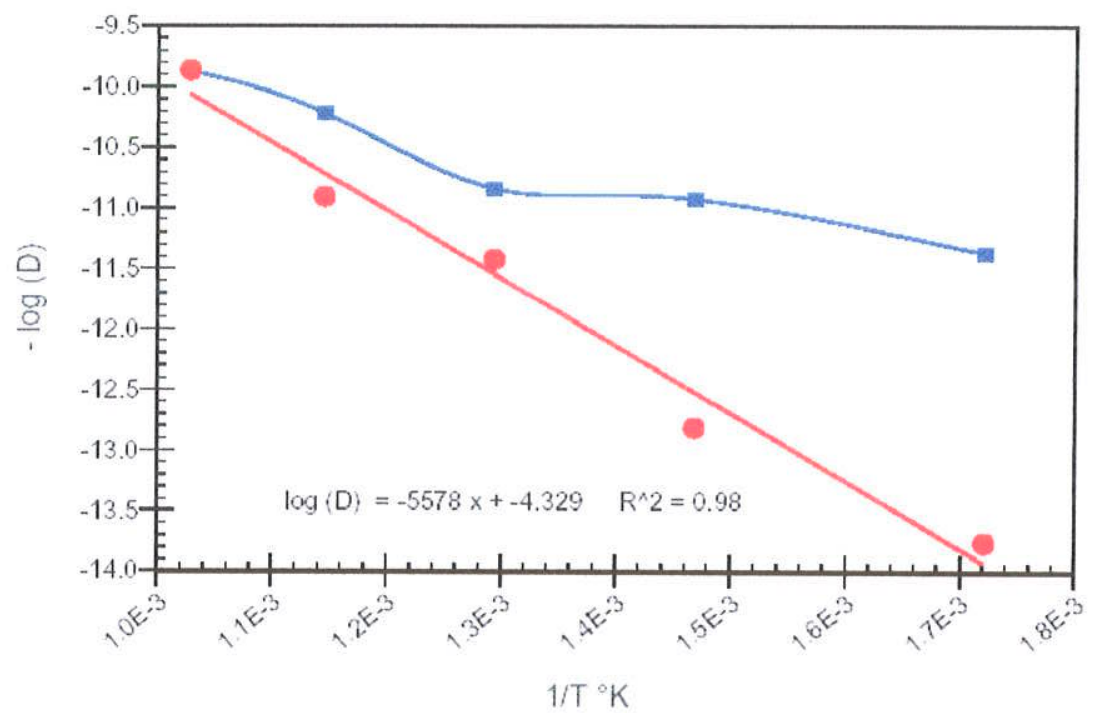

Figure 10. Arrhenius plot from step heating data for ${ }^{3} \mathrm{He}$ and ${ }^{4} \mathrm{He}$ with linear regression equation for ${ }^{4} \mathrm{He}$. The ${ }^{3} \mathrm{He}$ regression is not calculated as ${ }^{3} \mathrm{He}$ is not uniformly distributed in the alunite and therefore does not satisfy essential criteria for valid analysis of diffusion parameters. The ${ }^{4} \mathrm{He} \log (\mathrm{DO})=-4.329$ and activation energy $E=106.8(\mathrm{~kJ} / \mathrm{mole})$.

We discount ${ }^{3} \mathrm{He}$ on the grounds that it is not uniformly distributed throughout the alunite, but occurs redominantly in fluid inclusion sites. Figure 11 compares the Arrhenius plot release of $40 \mathrm{Ar}$ from separate splits of Tapajós X1-16/18 analyzed in the noble gas lab (unirradiated) and in the argon geochronology lab (irradiated). Results of these analyses and from all other Ar age spectra analyses are tabulated for comparison in Table 7a.

Table 7 a. Alunite Diffusion Properties

\begin{tabular}{|c|c|c|c|c|c|c|c|c|}
\hline \multirow[b]{2}{*}{ Noble Gas Lab } & $\log / D_{d}$ & Slope & $E$ & \multicolumn{5}{|c|}{ Conmens: } \\
\hline & \multicolumn{3}{|c|}{ Step-heating: Tapajós X1 - 16/18 } & \multirow[b]{5}{*}{$=$} & \multirow{2}{*}{\multicolumn{4}{|c|}{$\begin{array}{c}\text { Arrhenius Eqn. } \\
\log (D)=\log (D o)+E(2.303 R)^{*}(1 T)\end{array}$}} \\
\hline Helium-4 & -4.3285 & $-557 \mathrm{~s}$ & $\mid 00.81$ & & & & & \\
\hline Helium-3 & -7.8480 & $-2|0|$ & 40.23 & & & & & \\
\hline Argon-40 & 1.8689 & -11168 & 213.84 & & & & & \\
\hline Argon Lab & \multicolumn{3}{|c|}{ Age spectra extractions } & & $\delta^{\cdot 4} \mathrm{~s}$ & $\mathbf{T}\left({ }^{\circ} \mathrm{C}\right)$ & Age $(M a)$ & Location \\
\hline$F V 3-111$ & 14.5790 & -22964 & 439.69 & $\mathrm{~B}_{1}$ & 15.8 & 260 & 1867 & DHI $(55.1 \mathrm{~m})$ \\
\hline $\mathrm{N1}-16 / 18$ & 4.3910 & -14597 & 279.49 & $A_{1}$ & 26.7 & 250 & 1860 & Surface \\
\hline$F V 3-1 / 25$ & 15.4240 & -24000 & 450.53 & $\mathrm{~B}_{2}$ & 14.0 & 420 & 1858 & DIII (129.8m) \\
\hline $\mathrm{FV} 3-2 / 7$ & -0.0887 & -9359 & 179.19 & $\mathrm{~B}_{2}$ & 21.4 & 280 & 1857 & $\mathrm{DH} 2(127.8 \mathrm{~m})$ \\
\hline$X 1-16 F$ & 16.8140 & -25760 & 403.40 & $\mathrm{~A}_{3}$ & 14.3 & 420 & 1853 & Surface \\
\hline $\mathrm{X} 1-16 \mathrm{G}$ & 1.8764 & -10774 & 206.29 & $A_{2}$ & 38.2 & 130 & 1851 & Surface \\
\hline$F V 3-1 / 16$ & 2.6257 & -11247 & 215.35 & $\mathrm{~B}_{1}$ & & 300 & 1846 & DHI $(70.9 \mathrm{~m})$ \\
\hline$F V 3-116$ & 16.2560 & -25643 & 400.90 & $\mathrm{~B}_{1}$ & 18.2 & 300 & 1846 & DHI (70.9m) \\
\hline$F V 3-112$ & 13.5650 & -22972 & 439.85 & $\mathrm{Rul} / \mathrm{z}$ & 12.4 & -- & 1805 & $\mathrm{DHI}(58.2 \mathrm{~m})$ \\
\hline $\mathrm{FV} 3-3 / 3$ & 4.0056 & -1.3345 & 255.52 & SG & 4.1 & --- & 51.3 & DH3 $(66.7 \mathrm{~m})$ \\
\hline
\end{tabular}

"Alunite generation as described in Juliani. et al (this volume). DH = drill hok. TC is calculated 8 "S (alunitepyrite). $R x \mid z$ recrystallized. $S G=$ supergene. Bold type samples have Low Temperature Group diffusion parameters as discussed in lext. (sample FV3 - I/16 is separale material. not duplicate analysis). 
Table 7 b. Summary Diffusion Properties of Two Alunite Groups

\begin{tabular}{|c|c|c|c|c|}
\hline Almite & Arrhenius Eqh. & $\begin{array}{c}\text { Activalion Energy } \\
(\mathrm{h} / \text { hole })\end{array}$ & $\begin{array}{c}e^{4 / 5} \\
\text { (permil) }\end{array}$ & $\begin{array}{c}\text { Temp } \mathrm{C} \\
\text { rahonite-pyrite) }\end{array}$ \\
\hline L.ow-T & $\log (\mathrm{D})=2.4465-11748.3 *(1 \mathrm{~T})$ & 225 & 28.8 & 240 \\
\hline $\mathrm{Hi}-\mathrm{T}$ & $\log (D)=15.3276-242696 *(1 \mathrm{~T})$ & 465 & 14.9 & 350 \\
\hline
\end{tabular}

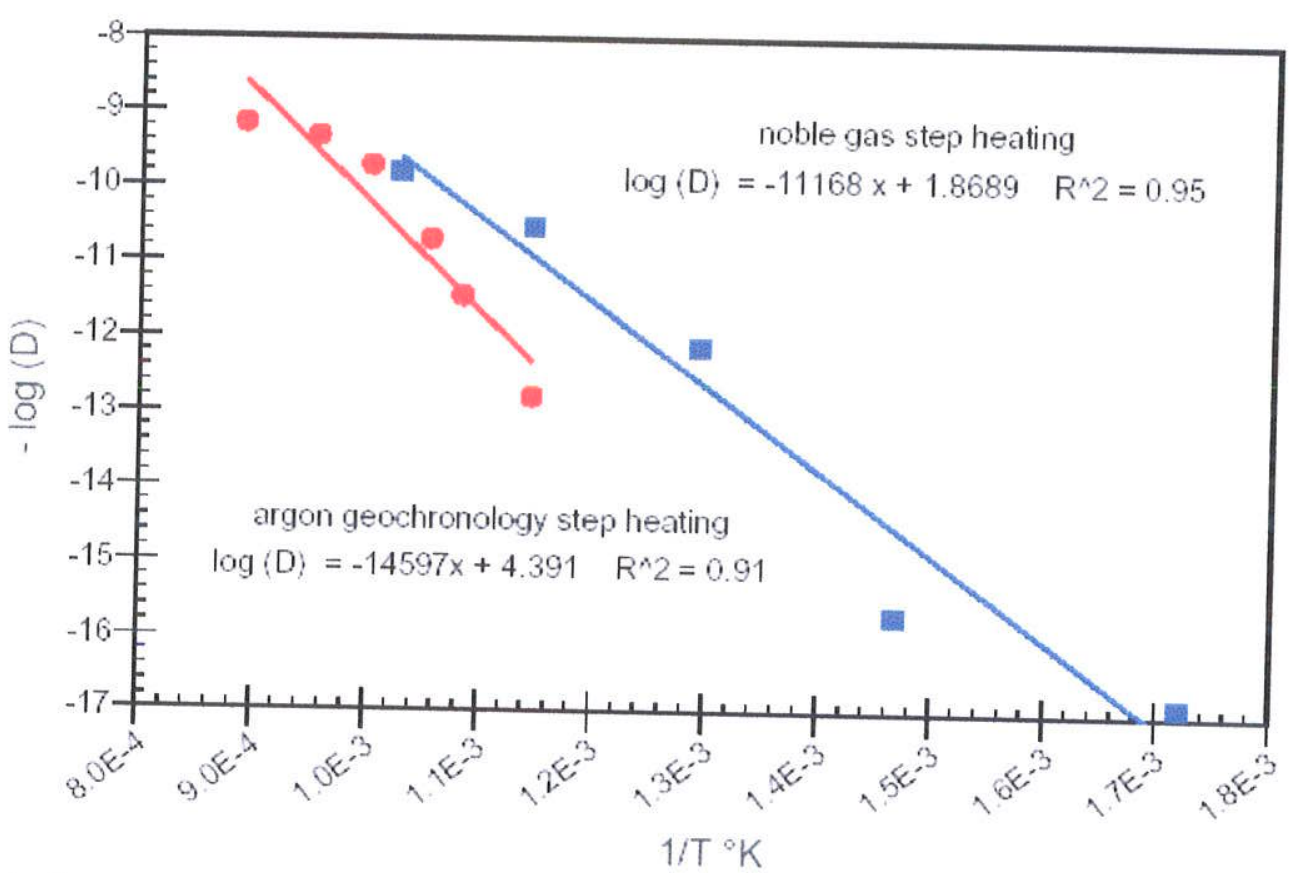

Figure 11. Arrhenius plot firom step heating data for ${ }^{\text {to }}$ Ar obtained in noble gas lab experiment extending to lower temperature than the compared data derived from the age spectra release of ${ }^{+0} \mathrm{Ar}$ in the geochronology analysis of an irradiated split from the same sample. Results are comparable with ${ }^{\text {to }} \mathrm{Ar}$. $\log (D O)=1.869$ and $t .391$ and activation energies $E=213.8$ and 279.5 (kJ mole) respectively. When combined with analysis of other age spectra release data (Table 6), results define two alunite populations (LTG and HTG) based upon their diffusion parameters and other criteria. See text for details.

Diffusion parameters are listed for each analysis in order from oldest mineralization to younger cooling or thermal resetting ages (Juliani, et.al., this volume).

These alunite data separate into two groups of diffusion parameters, with average activation energies of $225 \mathrm{~kJ} / \mathrm{mole}$ and $465 \mathrm{~kJ} / \mathrm{mole}$. As noted above, we identify these as hightemperature group (HTG) and low-temperature group (LTG) alunite. There possibly exist important differences between the chemical compositions of these two groups. We can find no correlation with age, geologic occurrence and paragenetic grouping (A1-A5 or B1-B3 alunite), texture, composition, or other simple physical attribute other than the crystallinity and fluid inclusion morphology and placement within the alunite. However, the two groups easily are distinguished in a plot (Figure 12) of activation energy $(\mathrm{kJ} / \mathrm{mole})$ versus $\delta^{34} \mathrm{~S}$ (alunite).

Temperatures calculated from sulfur isotope equilibrium fractionation between alunite and coexisting pyrite define a low-temperature group with $\mathrm{T}$ approximately $240^{\circ} \mathrm{C}$ and a hightemperature group with $\mathrm{T}$ approximately $350^{\circ} \mathrm{C}$ (Table $7 \mathrm{~b}$ ). The $\delta^{34} \mathrm{~S}$ (sulfate) of each group are $\delta^{34} \mathrm{~S}=28.8$ permil and $\delta^{34} \mathrm{~S}=14.9$ permil respectively 


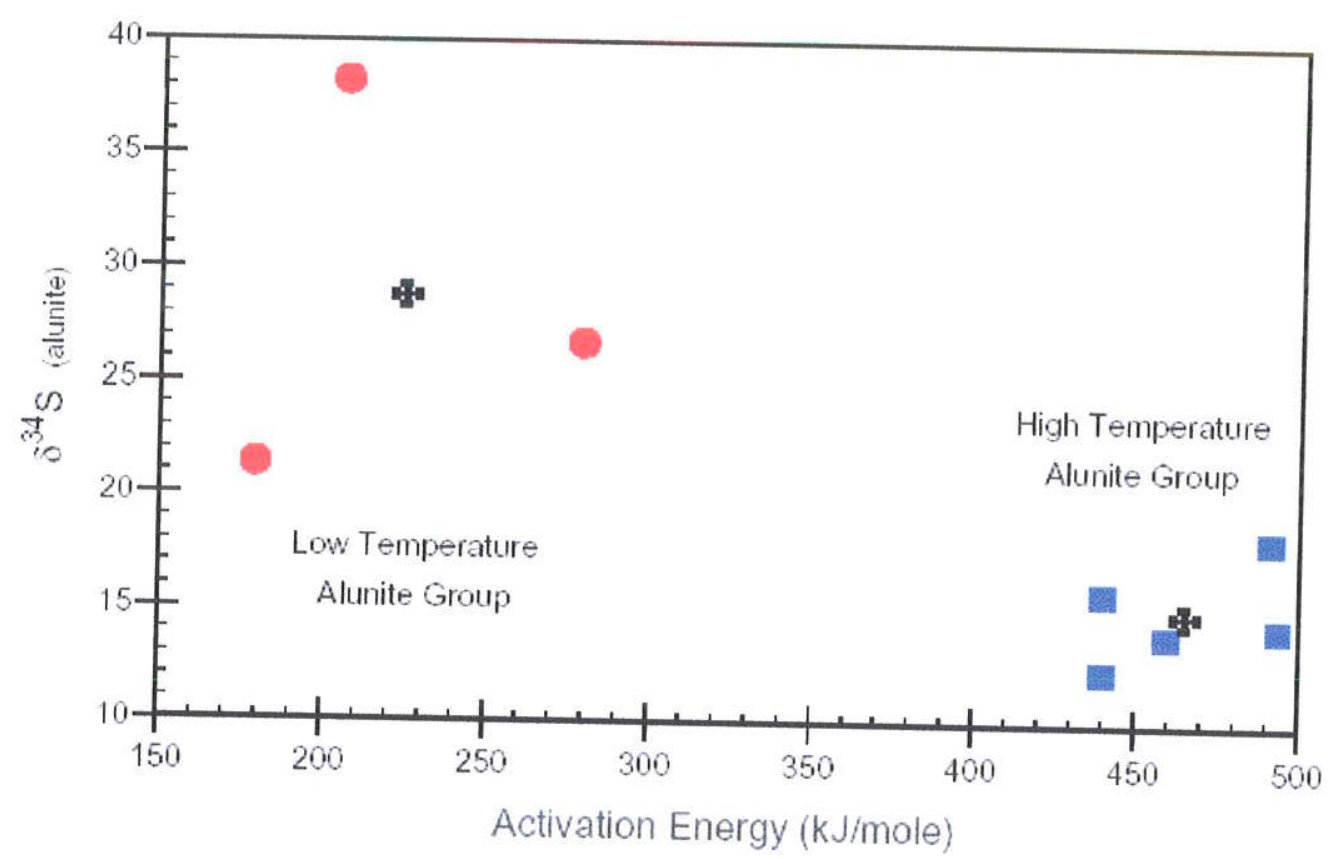

Figure 12. Comparison of the the two alunite groups based upon calculated activation energies and $\delta^{34} \mathrm{~S}$ of the alunite sulfate sulfur. Parameters characterizing the low temperatue group (LTG) and high temperature group (HTG) alunite samples from Tapajós are given in Table 7b. Cross symbol is the average of each group cluster.

We do not know the significance of these two groups of alunite from the Tapajós deposit, but suggest that the differences are real. The sulfur isotope compositions likely are nearequilibrium sulfate-sulfide isotopic partitioning with temperature, from the same bulk sulfur reservoir. We don't know what this implies for substantial differences in noble gas diffusion through the alunite crystal. Perhaps subtle differences in alunite chemistry and contrasting environmental conditions of deposition that yielded sulfur isotope changes has produced within alunite very different diffusion domains and pathways for movement of noble gas.

The diffusion coefficients thus calculated support the published assertion of other workers that alunite reliably retains argon for geochronologic purposes. We note that our derived diffusion coefficients and activation energies of argon and helium in alunite are similar to those obtained by others for various host minerals (Lippolt and Weigel, 1988; Trull and Kurz, 1999; Trull, et.al., 1991; Ozima and Podosek, 2002).

Taking the derived diffusion coefficients for ${ }^{4} \mathrm{He}$ and ${ }^{40} \mathrm{Ar}$ in alunite, we model the simplistic 1/e - folding time, based upon a spherical model, and a range of effective radii. The calculated time plotted as a function of temperature in Figure 13, is the time it takes to lose 1/e $(0.3679$ or roughly $1 / 3)$ of the uniformly distributed gas from a sphere of specified radius. 


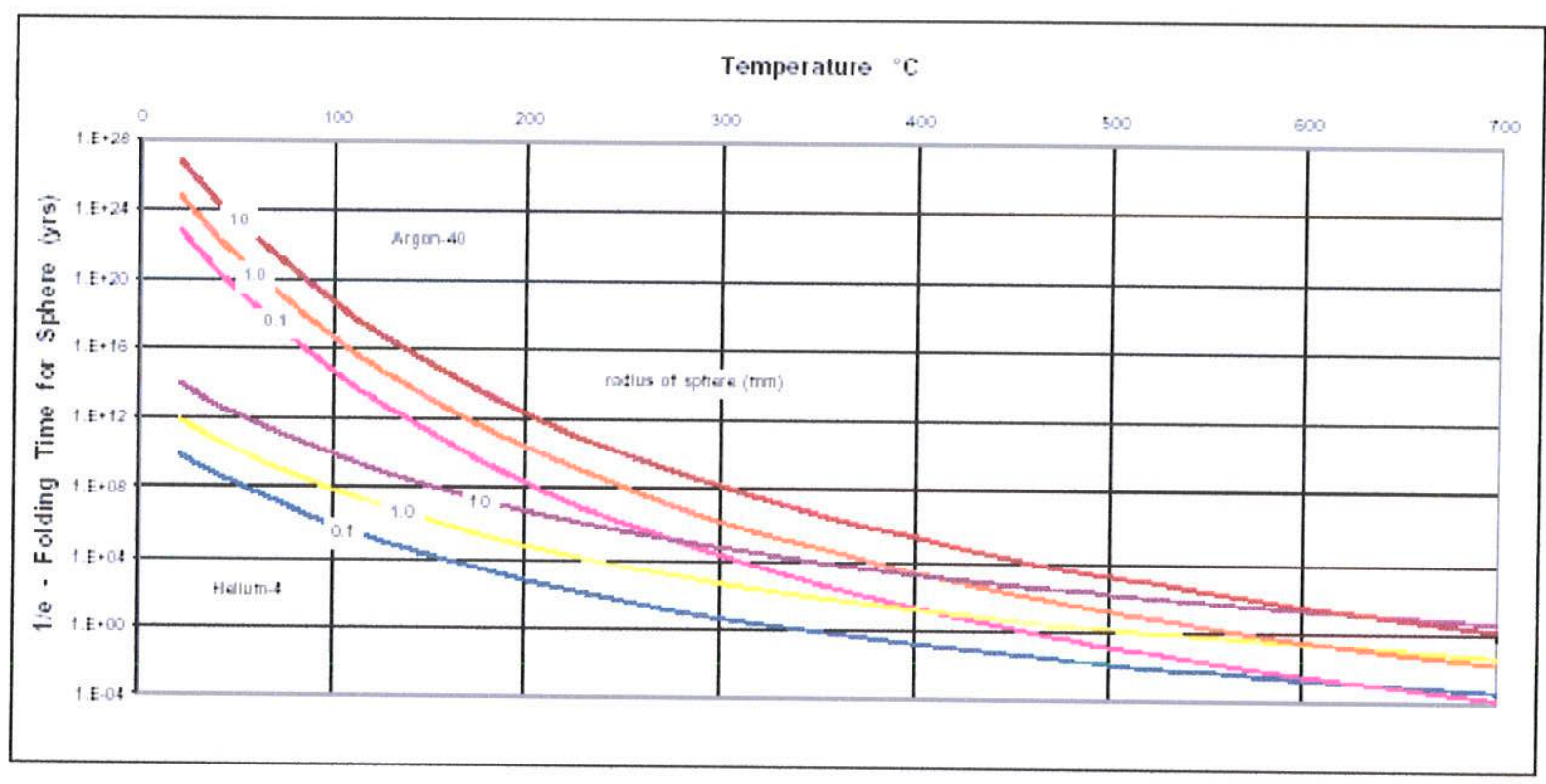

Figure 13. Model calculation of time to diffuse from a sphere a 1/e-folding amount of 40Ar and 4He from alunite using the LTG alunite diffusion parameters at sphere radii of 0.1 to $10 \mathrm{~mm}$. Helium is retained at $T \leq 100^{\circ} \mathrm{C}$ and argon at $T \leq 200^{\circ}-220^{\circ} \mathrm{C}$ as an approximate assessment.

We have used the LTG alunite diffusion constants to model the loss in Figure 13 as a limiting case, as virtually no argon is lost using the HTG parameters. From these calculations we conclude that ${ }^{4} \mathrm{He}$ is easily retained in alunite $\leq 100^{\circ} \mathrm{C}$ and ${ }^{40} \mathrm{Ar}$ is retained $\leq 200^{\circ}-220^{\circ} \mathrm{C}$. Figure 14 models diffusion distance for an infinite half-sheet geometry at temperature for $1 \mathrm{Ma}$ to $1 \mathrm{Ga}$. Helium should remain in alunite for millions of years at approximately $\leq 100^{\circ} \mathrm{C}$, whereas alunite below $200^{\circ} \mathrm{C}$ can retain argon virtually indefinitely.

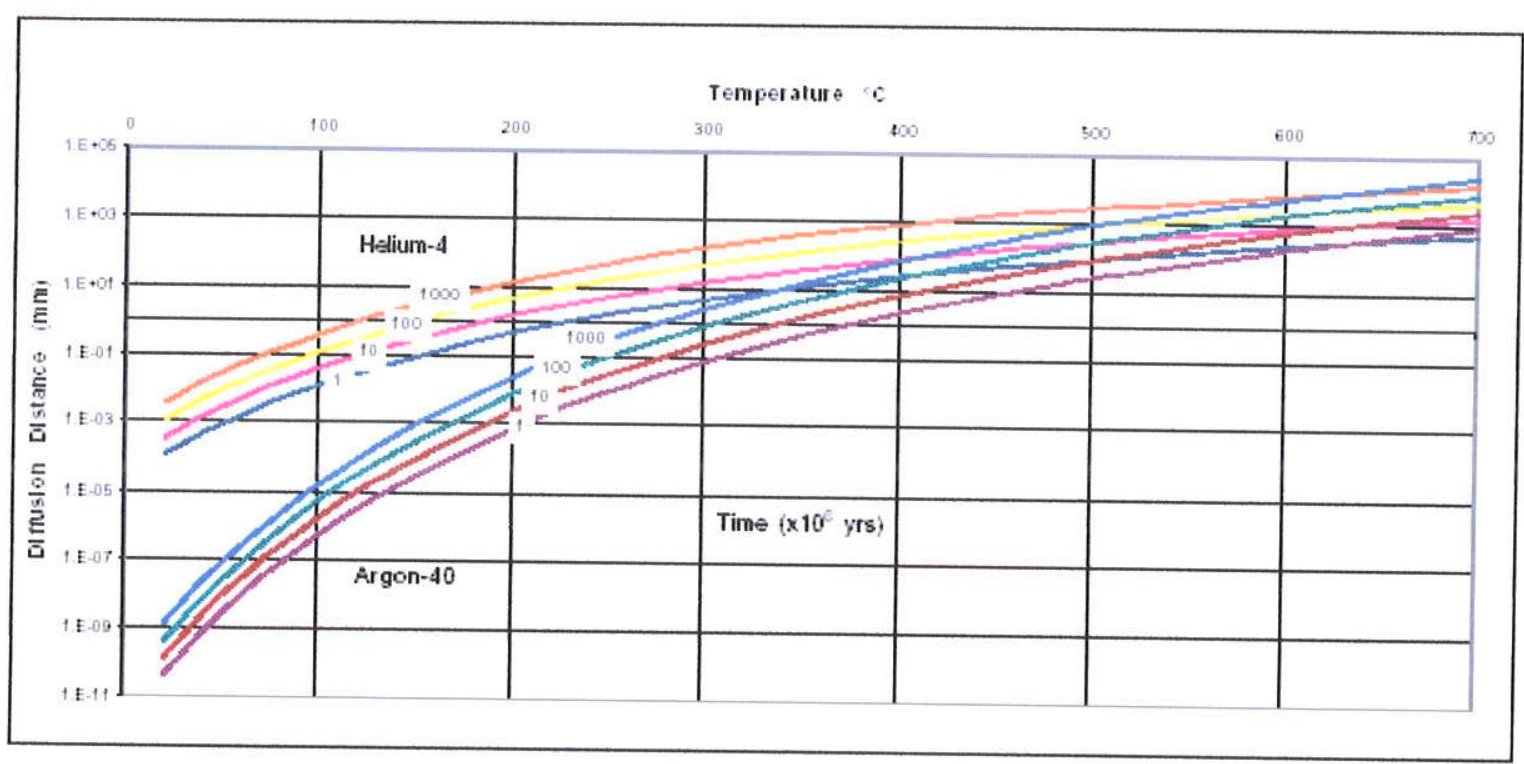

Figure 14. Model diffusion distances calculated using LTG alunite constants assuming an infinite halfsheet and times of $1 \mathrm{Ma}$ to $1 \mathrm{Ga}$. 


\section{Conclusions}

The patterns of gas released by crushing and thermal $\left(200^{\circ} \mathrm{C}\right)$, and step-heating to $700^{\circ} \mathrm{C}$ define several specific gas retention sites in alunite: 1) fluid inclusions, 2) structural water layers, and 3) alunite crystal structure. There appears to be minimal to no mixing between these sites, each exhibiting diagnostic gas, elemental, and isotopic composition. Argon is retained to high temperature within the time of the step-heating experiment. Fluid inclusion gas is thermally released quantitatively at approximately $200^{\circ} \mathrm{C}, \mathrm{OH}$-site hydration layer gas, including structural water, at $400^{\circ}-500^{\circ} \mathrm{C}$, and crystal structure gas from $500^{\circ}-700^{\circ} \mathrm{C}$ (perhaps to $<800^{\circ} \mathrm{C}$ from $40 \mathrm{Ar} / 39 \mathrm{Ar}$ release profiles). Maximum argon release at approximately $700^{\circ} \mathrm{C}$ is observed in alunite age spectra data reported here (Table 5) and in Juliani et.al., (this volume).

Tapajós alunite formed at $1.87 \mathrm{Ga}$ on the Amazonian cratonic margin, as part of a magmatic-hydrothermal mineralizing system hosted in a volcanic ring complex. Volatiles, including noble gases, record both a more primitive and less degassed mantle (magmatic) component in fluid inclusion sites, and a postentrapment component that isotopically has evolved through radiogenic and nucleogenic production. These observations are summarized in Table 6.

The $\mathrm{R} / \mathrm{Ra}$ of 19.5 indicates a less degassed mantle component distinctly more like a mantle hot spot (OIB) or more primative mantle. These experiments demonstrate that the fluid inclusions in this alunite have preserved a mantle helium, and likely the other magmatic gases characteristic of the genetic processes of magmatic-hydrothermal alunite formation for $1.87 \mathrm{Ga}$. It should be noted that none of the very much younger alunite deposits (Landis and Rye, this volume) yield this very distinctive mantle helium.

Based upon the step-heating release profiles of alunite samples from Tapajós, we recognize very distinct and well preserved gas and noble gas sites within alunite. Gas in fluid inclusions appears to be original trapped volatiles, modified only by subsequent radiogenic and nucleogenic reactions internal to the fluid inclusion volume, and not by diffusional loss and addition with the surrounding alunite crystal or depositional environment. Radiogenic ${ }^{40} \mathrm{Ar}$ and ${ }^{4} \mathrm{He}$ are preserved in the alunite crystal structure, even above the mineral dehydration transition, with maximum release approximately $600^{\circ} \mathrm{C}$. Model calculated diffusion parameters for helium and argon are totally consistent with the analytical results and proposed genetic implications.

Helium should remain largely unexchanged in alunite to at least $\geq 100 \mathrm{Ma}$ at temperatures below $100^{\circ} \mathrm{C}$. 
Table 6. Properties of Gas Retention Sites

\begin{tabular}{|c|c|c|c|c|}
\hline $\begin{array}{l}\text { Gas Retention } \\
\text { Sile }\end{array}$ & $\begin{array}{c}\text { Fluid } \\
\text { Inclusions }\end{array}$ & $\begin{array}{c}\text { Dehlhatrution } \\
\text { Leleter }\end{array}$ & $\begin{array}{c}\mathrm{K}-\mathrm{SO}_{4} \\
\text { Craval Matrix } \\
\end{array}$ & $\begin{array}{l}\text { Refierente' } \\
\text { Falue" }\end{array}$ \\
\hline Temperature "C & $2(10)-.301)$ & $4001-500$ & $501) \div 700$ & -- \\
\hline "Hono Release & 44.0 & 176 & 354 & -- \\
\hline the"o Release & 4.3 & 5.0 & 90.7 & -- \\
\hline${ }^{2} N \mathrm{Ne}^{\prime}$ n, Rslease & 12.4 & 0.2 & $\times 6.5$ & -- \\
\hline${ }^{22} \mathrm{Ne}^{*}=\mathrm{n}$, Release & 60.4 & 0.7 & 38.4 & -- \\
\hline "Ar "o Releass" & 0.04 & 0.21 & y9.72 & --- \\
\hline R Ra & 14.5 & 5.4 & $(1.2-1.9$ & $\begin{array}{c}\mathrm{Atm} . \\
\text { Mantle }=6.5\end{array}$ \\
\hline$" \mathrm{Ar}{ }^{36} \mathrm{Ar}$ & 615 & 1017 & $96.9(00)$ & 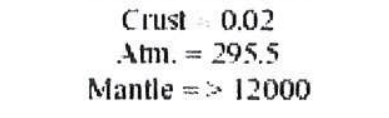 \\
\hline 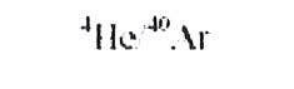 & $0.006-0.026$ & 0.0007 & $0.0001-0.000 \mathrm{~s}$ & $\begin{array}{c}\text { Mantle }=0.05-1000 \\
\text { Crustal Production }=4.9\end{array}$ \\
\hline${ }^{3 \times} \mathrm{Ar}{ }^{3 i} \mathrm{Ar}$ & $(1.011)(10-0.0002$ & 0.004 & $3.58-14.67$ & $\begin{array}{c}\text { Atm. - Crust } \\
=0.188\end{array}$ \\
\hline${ }^{20} \mathrm{Ne} \cdot{ }^{22} \mathrm{Ne}$ & $8.9-4.5$ & 9.7 & $8.4 \quad 9.2$ & $\begin{array}{c}\text { Atm. }=9.8 \\
\text { Mantle }=9.8-1.3\end{array}$ \\
\hline${ }^{21} \mathrm{Ne}^{* 2}{ }^{22} \mathrm{Ne}^{* *}$ & $0.028-0.0139$ & 0.065 & $0.057-0.4(11)$ & $\begin{array}{c}\text { Atm }=0.029 \\
\text { Mantle }=0.070 \\
\text { Avg. Crust }=0.47\end{array}$ \\
\hline${ }^{21} \mathrm{Ne}^{*}{ }^{4} \mathrm{He}\left(\mathrm{x} \mid \mathrm{O}^{7}\right)$ & $16-.3100)$ & 11 & $3-820$ & $\begin{array}{c}\text { Mantle Production }=5.9 \times 10^{7} \\
\text { Crust Production }=1.0 \times 10^{5}\end{array}$ \\
\hline${ }^{21} \mathrm{Ne}{ }^{*}:{ }^{41} \mathrm{Ar}\left(x 10^{-7}\right)$ & $0.42-26.5$ & 0.10 & $0.12-0.01012$ & $\begin{array}{c}\text { Crustal Production }= \\
4.94 \times 10^{-7}\end{array}$ \\
\hline
\end{tabular}

Alunite (and possibly jarosite or other compositional variants) appears to be an excellent K-bearing host mineral for argon geochronology applications, with 'closure temperatures' of approximately $200^{\circ} \mathrm{C}$. Submicron fluid inclusions in alunite should provide useful geochemical information of volatiles present at the time of alunite crystallization, and can be used to constrain the physical chemical nature of different alunite depositional environments and to refine our understanding of the processes that occur in these environments.

\section{Acknowledgements}

We wish to thank A.G. Hunt and L. Mills-Herring for their analytical support in assisting in the active and noble gas alunite step heating experiment, Amy Bern for providing the electron microprobe chemical analyses of selected alunites from this study, and George Breit for providing SEM images (all USGS). Ross Yeoman conducted many of the argon extractions. The many contributions from Carmen M.D. Nunes and Rafael H. Corrêa Silva to understanding the 
geologic context of Tapajós alunite are gratefully acknowledged. We thank the Fundaçyo de Amparo à Pesquisa doEstado de Syo Paulo, PRONEX/CNPq/UFPA and the Conselho Nacional de Pesquisa for support and access to the Tapajós deposits. The very old exceptional alunite specimens collected within a well-developed geologic context of the Tapajós gold district, the antiquity and magmatic-hydrothermal volcanic setting of these geologicallyundisturbed high sulfidation alunite samples, have proven crucial to our efforts to evaluate active and noble gas behavior in alunite. 1 


\section{CAPÍTULO VI \\ MINERALIZAÇÕES LOW-SULFIDATION}

\section{INTRODUÇÃO}

Os estudos deste tipo de mineralização foram concentrados em um domo situado na borda de uma estrutura maior aproximadamente circular, topograficamente rebaixada e plana, interpretada, em analogia ao verificado na mineralização high-sulfidation, como uma caldeira.

Esta estrutura morfológica é limitada por falhas normais concêntricas e associam-se falhas radiais, geradas pelo abatimento da parte intena, com moats ainda preservados, semelhantes às ash-flow calderas do sudoeste do Novo México, descritas por Elston (1984).

$\mathrm{Na}$ borda da caldeira ocorrem dezenas de possíveis volcanic vents (Fig. 1) arranjados ao longo das fraturas anelares e das falhas transcorrentes de direção principalmente NW-SE associadas à estrutura circular (Fig. 2). No seu centro também ocorre uma estrutura dômica, com possíveis vents associados, semelhantes a um domo ressurgente, como os que ocorrem na fase pós-abatimento, devido à recorrência do magmatismo, como descrito em várias regiões da América do Norte por Elston (1984) e Lipman (1984), dentre outros. O acesso às áreas com estas estruturas é muito difícil, mas espera-se, com a continuidade das pesquisas, a verificação de algumas delas.

As vulcânicas desta área compõem duas seqüências litotípicas, uma Inferior correlacionável à Formação Bom Jardim, e outra Superior, correlata às formações Salustiano e Aruri, ambas invadidas por intrusões de granitos epizonais, diques de dacito e de pórfiros riolíticos e riodacíticos.

\section{GEOLOGIA E LITOLOGIA}

A estratigrafia e litologia resumida da área é a seguinte:

\subsection{Embasamento}

As rochas do embasamento não foram cartografadas em detalhe na área, mas segundo Coutinho et al. (1998), Almeida et al. (2000), Bahia \& Quadros (2000), Ferreira et al. (2000), Klein \& Vasquez (2000) e Vasquez \& Klein (2000), o embasamento da rochas vulcânicas é composto granitóides da Suíte Intrusiva Parauari, de modo análogo ao observado na área de ocorrência das mineralizações formadas por sistemas high-sulfidation na Província Aurífera do Tapajós.

Os poucos afloramentos e amostras estudadas do embasamento são formados por biotita granodiorito, hornblenda granodiorito e tonalito cinzas a róseos, com estrutura maciça, 
localmente foliada, e textura fanerítica inequigranular média a fina.

Santos et al. (2000) consideram estes granitóides como representantes do segundo arco magmático paleoproerozóico que sucedeu a construção do Complexo Cuiú-Cuiú da Província Tapajós-Parima.

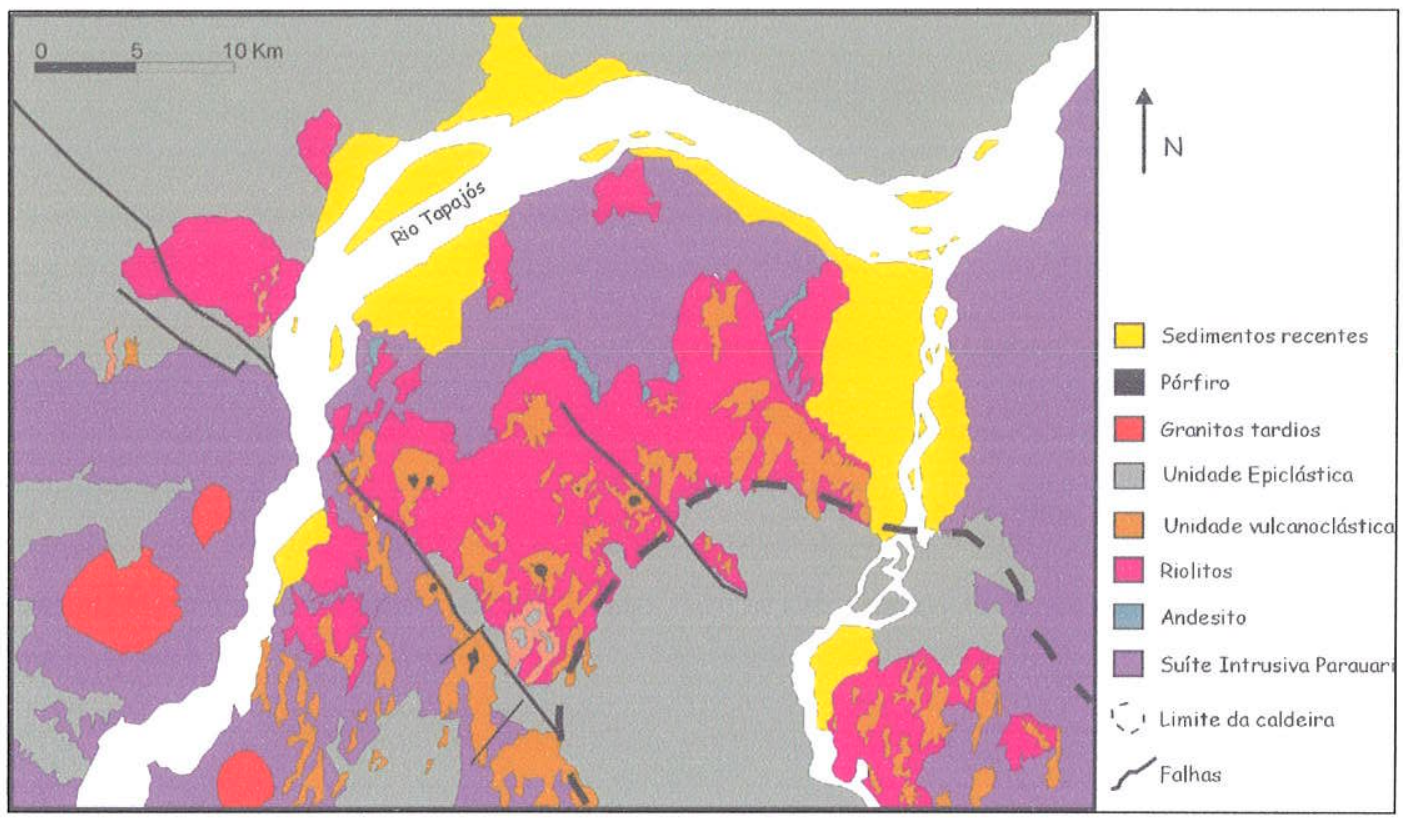

FIGURA 1 - Esboço geológico da região das mineralizações low-sulfidation, segundo CorrêaSilva (2002).

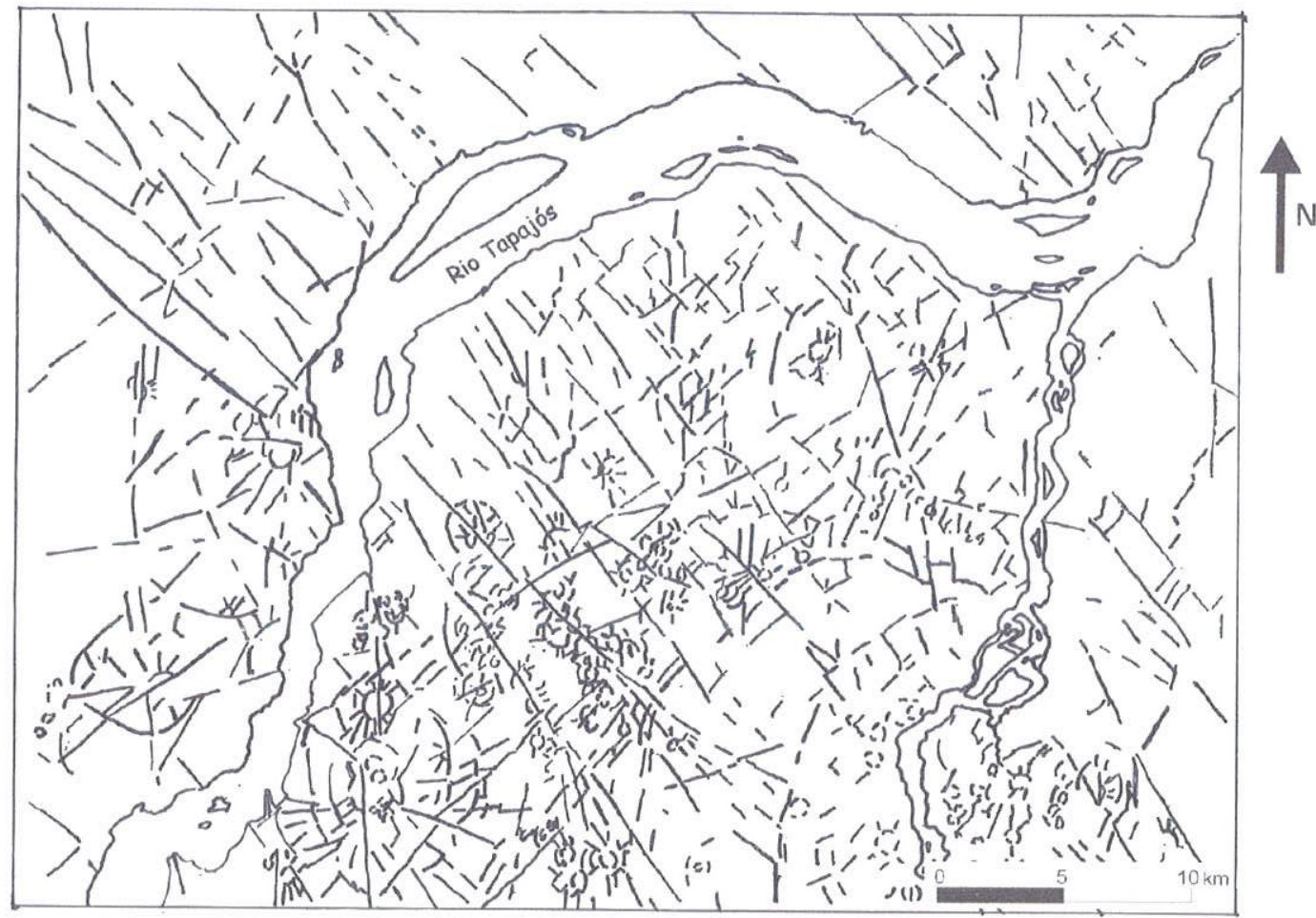

FIGURA 2 - Esboço das estrutura das mineralizações low-sulfidation, segundo Corrêa-Silva (2002). 


\subsection{Granitos}

Esta unidade agrupa os granitos intrusivos nas seqüências supracrustais e nos granitóides sin-colisionais da Suíte Intrusiva Parauari. Estas rochas podem ser correlacionáveis aos granitos da Suíte Intrusiva Maloquinha ou, mais provavelmente, às fácies tardi- a pós-colisionais da Suíte Intrusiva Parauari, semelhantemente ao descrito por Juliani et al. (no prelo).

Os corpos deste granito constituem stocks com secções circulares e elipsoidais em planta que variam de 1 a $8 \mathrm{~km}$ de diâmetro ou no eixo maior. Também foram observadas apófises com algumas centenas de metros de extensão.

As rochas mostram cor cinza a rosa, são freqüentemente leucocráticas e, às vezes, hololeucocráticas. Geralmente são maciças mas, localmente, encontram-se milonitizados nas proximidades das zonas de cisalhamento.

Texturalmente são rochas faneríticas de granulação média a grossa, inequigranulares, localmente porfiríticas, com megacristais de feldspato potássico e plagioclásio dispersos em matriz fanerítica média a grossa constituída por quartzo, plagioclásio, feldspato potássico e biotita.

Os contatos do granito com as rochas encaixantes são intrusivos e, localmente, limitamse por falhas transcorrentes de direção NW-SE e normais na borda das estruturas anelares.

\subsection{Seqüência Inferior}

A Seqüência Inferior é constituída por derrames de andesito na base e por domos de riolito porfirítico que sustentam os altos topográficos e recobrem parcialmente os corpos de andesito, atingindo a cota aproximada de $550 \mathrm{~m}$. Estas unidades correspondem à fase vulcânica pré-caldeira, com a formação dos domos e a construção do edifício vulcânico maior semelhante a um estratovulcão (ou composite volcano), onde o riolito freqüentemente encontra-se intercalado em tufos.

As principais unidades litotípicas distinguíveis são:

\subsubsection{Andesitos}

Esta unidade é composta por derrames de andesito de cor variando de preta a verde escura na base, com espessuras métricas. A estrutura é quase sempre maciça e as rochas são faneríticas finas e inequigranulares. Localmente os derrames são cortados por veios e diques de espessura até métrica de pórfiro riolítico e riodacítico e de dacito. Principalmente no topo dos derrames ocorrem ocorrem zonas com vesículas esparças alongadas por fluxo, com até 1,5 cm de comprimento, preenchidas por clorita e carbonatos. 
Comumente pode-se observar que os derrames recobrem granitóides da Suíte Intrusiva Parauari mas, muitas vezes, o contato com os granitóides se dá através de falhas.

\subsubsection{Riolitos porfiríticos}

A unidade dos riolitos porfiríticos é a predominante na área detalhada, recobrindo-a em cerca de $60 \%$. Esta unidade constitui domos vulcânicos, com estruturas anelares que representam possíveis raízes de vents vulcânicos, associadas e derrames intercalados em tufos ácidos.

Em imagen de satélite comumente esta unidade constitui formas linguóides distribuídas ao redor das estruturas anelares e dos vents, sugerindo representarem derrames individuais ou compostos, com fluxo centrífugo, mas predominantemente dirigido para fora da caldeira.

Os domos destacam-se na topografia e sustentam a borda da estrutura circular maior, limitados por falhas normais anelares e radiais. Nas porções mais distais da caldeira estas vulcânicas ocorrem comumente como morros-testemunho, devido à erosão mais acentuada das vulcâncias e vulcanoclásticas.

Os riolitos são maciços, têm cor rosa a vermelho-acastanhado escuro e possuem textura porfirítica, com fenocristais bipiramidais de quartzo e megacristais de feldspato potássico e plagioclásio imersos em matriz fanerítica muito fina a afanítica. Localmente apresentam estrutura de fluxo ígneo, dada principalmente pela orientação dos megacristais, e são, localmente, cortados por veios hidrotermais formados principalmente por quartzo, sericita e pirita.

Comumente o riolito encontra-se fortemente fraturado e, geralmente, estas zonas serviram como conduto para os fluidos responsáveis pela alteração hidrotermal associada ao vulcanismo. Em alguns casos o fraturamento é devido a atividades vulcânicas explosivas, chegando a desenvolver brechas hidrotermais, mas, em outros casos, relaciona-se a zonas de cisalhamento tardias.

Intercalações do riolito com tufos e ignimbritos foram também identificados nos testemunhos de sondagem. Estes corpos apresentam contatos bruscos, por vezes erosivos, e possuem espessuras que variam de 1 a $5 \mathrm{~m}$. Estas zonas de intercalação ocorrem tanto na Seqüência Superior como na Inferior, evidenciando o caráter recorrente do magmatismo.

O contato do riolito porfirítico com o granito faz-se comumente através de falhas, mas foram também observadas relações de intrusão, com apófises de granito encaixadas no riolito.

\subsection{Seqüiência Superior}

Foram agrupadas nesta Seqüência as rochas vulcânicas, vulcanoclásticas e epiclásticas, 
bem como os sedimentos produzidos pela erosão da pilha vulcânica. Esta Seqüência recobre as rochas da Seqüência Inferior, com a qual apresenta contatos bruscos concordantes ou erosivos.

As rochas que compõem esta seqüência foram subdivididas em duas unidades, uma predominantemente vulcanoclástica e outra principalmente epiclástica. Ambas ocorrem freqüentemente interdigitadas, o que caracteriza uma sucessão de eventos eruptivos entremeados por períodos de calmaria, com erosão e deposição de sedimentos clásticos.

A formação das rochas de ambas unidades relaciona-se à fase sin- a pós-caldeira, marcada pela formação de pequenos domos, vents e vulcões menores compostos ou estratificados (composite ou stratovolcanoes) na borda da estrutura circular e associados a fraturas anelares, ou seja, são decorrentes da ressurgência vulcânica causada pelo abatimento da caldeira.

Suas principais características são as seguintes:

\subsubsection{Vulcanoclásticas}

As rochas vulcanoclásticas são compostas, em essência, por ignimbritos, brechas coignimbríticas e tufos de cristais.

\subsubsection{Ignimbritos}

O termo ignimbrito é usualmente empregado para classificar rochas piroclásticas com um certo grau de soldagem (tufos soldados). Entretanto, neste trabalho, o termo é empregado segundo a recomendação de Sparks et al. (1973), ou seja, refere-se a rochas formadas por fluxo piroclástico.

Os ignimbritos desta fácies são compostos predominantemente por tufos e tufos soldados, de composição ácida, com estruturas acamadadas e grandes variações na granulação dos fragmentos, que são predominantemente angulosos.

Os tufos e tufos soldados concentram-se em leitos, mas não constituem camadas contínuas. Apresentam intensa deformação adiastrófica, com dobras convolutas e lentes amalgamadas em meio às brechas coignimbríticas que, por sua vez, possuem matriz predominantemente composta por cinzas vulcânicas e tufos.

Os tufos apresentam estruturas e texturas de fluxo piroclástico e possuem cor predominante rosa, com variações para tons cinza-arroseados em porções menos afetadas pelo hidrotermalismo.

Os ignimbritos afloram principalmente no topo dos domos riolíticos e concentran-se na borda da paleocaldeira, distribuindo-se centrifugamente a partir de estruturas circulares menores, 
interpretadas como antigos vents vulcânicos. Formam corpos lobulares semelhantes às formas geradas por depósitos de fluxo de lama.

Sua posição atual no topo dos domos vulcânicos é devida à erosão, que removeu parte dos depósitos ignimbríticos que deveriam originalmente ter sido depositados preferencialmente nos baixos topográficos e nas antigas drenagens.

Os ignimbritos encontram-se intercalados em brechas coignimbríticas, tufos de cristais e tufitos. As intercalações tem espessuras variando de centimétricas a métricas, e apresentam contatos bruscos, o que torna difícil a separação destas unidades na escala do esboço geológico apresentado na Fig. 1. Nas porções mais basais da estrutura vulcânica maior e no interior da caldeira, os ignimbritos estão intercalados em arenito vulcânico epiclástico e em ritmito, característica esta que evidencia a recorrência da atividade vulcânica em pulsos.

As rochas desta unidade encontram-se alteradas hidrotermalmente em diferentes estilos e intensidades e, localmente, são cortadas por zonas de cisalhamento, representadas no esboço geológico e identificadas nos testemunhos de sondagens.

Capas de sílica (silica cap) com sulfetos, localmente alterados e substituídos por limonita, são comuns nos topos de morros onde afloram blocos de ignimbrito.

\subsubsection{Tufos}

Esta fácies é composta predominantemente por tufos ácidos de cor creme a cinzaamarelada, com estrutura maciça, localmente com estratificação plano-paralela dada pela alternância de bandas de lápilli tufos com leitos de tufo cinerítico fino. Comumente encontramse dobrados convolutamente.

Estas rochas ocorrem intercaladas em corpos de tufo soldado e de riolito, onde constituem bandas centimétricas a métricas. Exibem contatos bruscos com o riolito e gradacional e com os tufos, sendo esta separação muitas vezes possível somente ao microscópio. Também ocorrem como intercalações no arenito vulcânico e no ritmito, com os quais apresentam contatos gradacionais e, devido às dimensões dos corpos, são muitas vezes de difícil separação na escala do esboço geológico apresentado.

\subsubsection{Tufos soldados}

Os tufos soldados tem estrutura variando entre maciça e estratificada, composição ácida e cor creme a rosa-claro. A estratificação é devida à compactação e soldamento dos fragmentos vítreos e de púmice e, na matriz, localmente são observadas porções mais compactadas e estiradas (fiammes) e textura eutaxítica. 
Esta laminação é aparente, pois é dada pela textura eutaxítica e, localmente, está dobrada convolutamente e perturbada por bombas vulcânicas e ejetólitos que provocaram deformação por carga.

\subsubsection{Brechas coignimbríticas}

Este litotipo ocorre intimamente relacionado aos ignimbritos tendo sido, portanto, agrupado com as rochas da unidade vulcanoclástica no esboço geológico. Os corpos de brecha coignimbrítica afloram na base de estruturas cônicas e associada aos ignimbritos e são muitas vezes envolvida por eles.

Sua principal característica é uma estrutura brechada, com fragmentos variando de angulosos a subarredondados, polimíticos, centimétricos a métricos, imersos em matriz composta por cinza e vidro vulcânico, púmice e fragmentos líticos menores. Os clastos são de riolito porfirítico, tufos, tufitos, chert, ritmitos, arenitos tufáceos a arcoseanos e andesito.

\subsubsection{Tufos de cristais}

Estes litotipos afloram nas bordas das estruturas anelares maiores, onde ocorre intercalado em tufos soldados, tufitos e, localmente, em brechas coignimbríticas. Têm cor variando de cinza a rosa, estrutura maciça, localmente bandada, e estratificação plano-paralela marcada pela alternância entre leitos cineríticos finos e tufáceos. São também comuns intercalações de bandas e leitos de espessura centimétrica de granulação mais grossa, onde predominam fragmentos milimétricos de quartzo e feldspato, preservando ainda formas euédricas. Estes fragmentos podem também ser identificados imersos na matriz tufácea, assim como textura eutaxítica, dada pelo estiramento e soldagem de fragmentos vítreos, resultando em discreto bandamento. A estratificação plano-paralela localmente apresenta dobras convolutas.

Os contatos do tufo de cristais com o tufo soldado e com o tufo são geralmente gradacionais, mas são bruscos com as brechas coignimbríticas.

\subsubsection{Rochas epiclásticas}

A unidade epiclástica é constituída por tufitos, arenito vulcânico epiclástico, silexito e ritmito.

\subsubsection{Tufitos}

Esta fácies é formada predominantemente por corpos de tufitos distribuídos nas bordas das estruturas cônicas e nas partes internas das estruturas circulares. Nesta última situação 
usualmente ocorrrem intercalados em sedimentos e tufos e compõem o preenchimento da caldeira. Quando associados com as estruturas cônicas estão principalmente intercalados em tufos e derrares de riolito.

Nas porções internas das estruturas circulares, onde o tufito intercala-se em arenitos, silexito e ritmitos, os contatos com as encaixantes são gradacionais e, muitas vezes, são de difícil identificação, tanto no campo como em amostras de mão. Nas bordas das estruturas cônicas, onde os tufitos ocorrem intercalados em riolito e tufos, os contatos são usualmente bruscos.

Sua cor varia de cinza a rosa, apresentam bandamento plano-paralelo, localmente dobrado e, mais raramente, são maciços. A estratificação é marcada pela alternância de leitos onde predominam cinzas vulcânicas e tufos com leitos onde a contribuição de fragmentos líticos nas frações silte e areia de origem sedimentar é mais importante.

\subsubsection{Arenitos vulcânicos epiclásticos}

Esta fácies ocorre nas porções centrais das estruturas anelares, preenchendo bacias pullapart de direção predominante NW-SE e intercalados em tufito, tufos, ritmito e leitos de chert.

Têm cor variando entre ocre e levemente rosa e, geralmente, estrutura maciça mas, localmente, apresenta estratificações plano-paralela e cruzada de médio porte. As camadas estão inclinadas na área detalhada, com mergulho variando entre 5 e $25^{\circ}$, em função da presença de dobras abertas e basculamentos. Em alguns poucos afloramentos foram observadas marcas onduladas, indicando, localmente, sedimentação subaquática.

$\mathrm{O}$ arenito possui baixa maturidade textural e mineralógica e fragmentos angulosos de quartzo, feldspatos e fragmentos líticos. Composicionalmente variam entre arenito e arcóseo.

Freqüentemente estão muito silicificados ao redor de veios, mas são comuns extensas zonas de silicificação sem veios hidrotermais associados, que pode ter sido gerada diagenéticamente.

\subsubsection{Silexito}

O silexito ocorre como bandas de espessura centimétrica e camadas métricas intercaladas no arenito epiclástico e no ritmito. Possuem cor cinza a cinza levemente rosado, estrutura bandada plano-paralela, localmente laminada ou maciça. Estruturas de deformação por carga e ejetólitos freqüentemente perturbam a laminação.

Os contatos do silexito com o ritmito são predominantemente concordantes e bruscos e com o arenito são principalmente bruscos e discordantes na base, mas em algumas porções no topo são erosivos, indicando canibalização do silexito pelo arenito. 
Devido à pequena espessura dos leitos de silexito, esta unidade foi agrupada com a unidade dos sedimentos epiclásticos.

\subsubsection{Ritmitos}

As rochas desta fácies ocorrem principalmente nas porções mais centrais das estruturas circulares e, mais raramente, no interior das bacias pull-apart orientadas segundo NW-SE. Tipicamente estão intercaladas na Seqüência Epiclástica, mas também ocorrem como leitos subordinados em tufos da Seqüência Vulcanoclástica.

As intercalações de ritmitos constituem pacotes que variam desde alguns poucos centímetros a algumas dezenas de metros de espessura, mas predominam corpos com 4 a $9 \mathrm{~m}$. Possuem estratificação plano-paralela dada pela alternância de bandas decimétricas a centimétricas na fração argila, com bandas decimétricas na fração silte a areia fina. Internamente as porções argilosas apresentam laminação plano-paralela que, localmente, encontra-se rompida. Quando intercalado nos tufos e tufitos os contatos dos corpos de ritmitos são gradacionais no topo e bruscos na base.

A cor do ritmito varia de cinza a crème e, comumente o conjunto encontra-se muito silicificado, tornando a observação dos contatos muito difícil, mesmo em testemunhos de sondagem.

\subsection{Dacitos}

$\mathrm{O}$ dacito ocorre sob a forma de diques e apófises de espessuras centimétricas à métricas, encaixados nas rochas das seqüências Superior e Inferior.

Os seus contatos com as encaixantes são intrusivos mas, localmente, são balizados por falhas e, comumente, estão presentes bordas de reação nas encaixantes.

Sua cor varia de negra a verde-escuro e, texturalmente o dacito é porfirítico, com megacristais de plagioclásio, quartzo e ortoclásio imersos em matriz afanítica à fanerítica muito fina, constituída por anfibólio, plagioclásio, feldspato potássico e quartzo. Os megacristais estão freqüentemente arredondados, por dissolução magmática ou fluxo.

\subsection{Pórfiros}

Diversos corpos de pórfiros ocorrem sob forma de diques e apófises, com espessuras variando entre 1 e $450 \mathrm{~m}$ que, caracteristicamente se distribuem nas porções centrais de estruturas circulares concêntricas menores, com fraturas e diques radiais associadas, indicando tratarem-se de intrusões relacionadas com a formação da brechas hidrotermais. 
Os pórfiros tem cor cinza a marrom, estrutura é maciça e textura porfirítica, com megacristais, fenocristais e xenocristais de quartzo, plagioclásio, feldspato potássico e biotita, imersos em matriz variando de fanerítica fina, com a mesma composição mineralógica dos cristais mais grossos, a vítrea.

O pórfiro é intrusivo nas vulcânicas e no granito tardio, principalmente nas porções centrais e adjacências de estruturas circulares concêntricas. A colocação das intrusões é, em alguns casos, balizada por falhas, onde, freqüentemente podem ser observadas reativações posteriores ao magmatismo, evidenciado pelo desenvolvimento de pequenas zonas de cisalhamento nos pórfiros, com geração de protocataclasitos.

\subsection{Brechas de Conduto}

As brechas de conduto formam corpos no centro e nas bordas das estruturas anelares menores, com dimensões variando de centimétricas até algumas centenas de metros, geralmente com formas de funil. Os seus contatos com as encaixantes são abruptos, verticais a oblíquos e intrusivos.

As brechas são formadas por clastos mais finos e blocos angulosos das rochas encaixantes, incluindo riolito, andesito, dacito, granito, arenito, ignimbrito, tufos, tufitos e pórfiro, envolvidos por uma matriz composta por fragmentos líticos menores das mesmas rochas. Estas rochas são predominantemente clasto-suportada e mostra discreta granodecrescência ascendente.

\section{ALTERAÇÃO HIDROTERMAL}

A terminologia utilizada na descrição da alteração hidrotermal (Fig. 3) é baseada nos trabalhos de Meyer \& Hemley (1967), Heald et al. (1987) e Pirajno (1992).

Segundo estes critérios, o conjunto vulcanossedimentar aqui estudado pode ser classificado como um sistema epitermal low-sulfidation afetado por metassomatismo sódico e potássico, alteração sericítica com adulária, alteração propilítica com adulária e alteração argílica, todas observadas em diferentes estilos e intensidades, a seguir descritas:

\subsection{Metassomatismo Sódico}

O metassomatismo sódico é produto da interação da rocha encaixante com fluidos residuais derivados cristalização de um corpo ígneo, em temperatura entre 300 e $800{ }^{\circ} \mathrm{C}$, com pouca ou nenhuma participação de fluidos meteóricos e foi reconhecido nas rochas estudadas pela cristalização pervasiva de albita e quartzo nos corpos de granito e de pórfiros. 


\begin{tabular}{|c|c|c|c|c|c|}
\hline $\begin{array}{l}\text { Terminologia } \\
\text { adotada neste } \\
\text { trabalho }\end{array}$ & $\begin{array}{c}\text { Terminologia } \\
\text { de Heald et al. } \\
(1987)\end{array}$ & $\begin{array}{l}\text { Características da } \\
\text { alteração deste } \\
\text { trabalho }\end{array}$ & $\begin{array}{c}\text { Características da } \\
\text { terminologia de } \\
\text { alteração de Heald } e t \\
\text { al. (1987) } \\
\end{array}$ & $\begin{array}{l}\text { Características da } \\
\text { alteração de Meyer } \\
\text { \& Hemley (1967) }\end{array}$ & $\begin{array}{c}\text { Outros termos } \\
\text { utilizados na } \\
\text { literatura }\end{array}$ \\
\hline $\begin{array}{l}\text { Metassomatismo } \\
\text { sódico }\end{array}$ & & $\begin{array}{l}\text { Introdução de sódio } \\
\text { no sistema, } \\
\text { caracterizado pela } \\
\text { cristalização de } \\
\text { albita, subtituindo } \\
\text { feldspato alcalino e } \\
\text { intersticial }\end{array}$ & & & $\begin{array}{c}\text {-Sodic } \\
\text { metasomatism } \\
\text {-Alkali } \\
\text { metasomatism } \\
\text { - Albititization }\end{array}$ \\
\hline $\begin{array}{l}\text { Metassomatismo } \\
\text { potássico }\end{array}$ & $\begin{array}{c}\text { Potassium } \\
\text { metasomatism }\end{array}$ & $\begin{array}{c}\text { Introdução de } \\
\text { potássio, } \\
\text { representado pela } \\
\text { cristalização de } \\
\text { feldspato potássico, } \\
\text { biotita e quartzo } \\
\text { intersticial e } \\
\text { substituindo minerais } \\
\text { do estágio } \\
\text { magmático }\end{array}$ & $\begin{array}{l}\text { Caracterizado pela } \\
\text { introdução de } \\
\text { potássio resultando } \\
\text { na recristalização na } \\
\text { encaixante de } \\
\text { assembléias ricas em } \\
\text { feldspato potássico e } \\
\text { biotita }\end{array}$ & $\begin{array}{c}\text { Incluído na } \\
\text { classificação } \\
\text { potassium silicate de } \\
\text { Meyer \& Hemley } \\
\text { (1967) }\end{array}$ & $\begin{array}{c}\text {-Alkali } \\
\text { metasomatism } \\
\text { - Potassium } \\
\text { silicate } \\
\text { alteration }\end{array}$ \\
\hline $\begin{array}{l}\text { Alteração } \\
\text { sericítica com } \\
\text { adulária }\end{array}$ & $\begin{array}{l}\text { K-Feldspar } \\
\text { Sericitic }\end{array}$ & $\begin{array}{c}\text { Cristalização de } \\
\text { sericita, quartzo, } \\
\text { adulária, pirita, } \\
\text { calcopirita, } \\
\text { molibdenita e ouro, } \\
\text { inicialmente em } \\
\text { veios, mas gradando } \\
\text { a pervasivo }\end{array}$ & $\begin{array}{l}\text { Feldspato potássico } \\
\text { (incluindo adulária) } \\
\text { + sericita + pirita }\end{array}$ & $\begin{array}{l}\text { Feldspato potássico } \\
+ \text { micas + magnetita } \\
+ \text { hematita } \pm \text { anidrita } \\
\text { +carbonatos ricos } \\
\text { em ferro }\end{array}$ & $\begin{array}{l}\text {-Adularia } \\
\text { - Sericitic } \\
\text { - Potassic } \\
\text { - Phyllic } \\
\text {-Quartz-sericite } \\
\text { - Illitic }\end{array}$ \\
\hline $\begin{array}{c}\text { Alteração } \\
\text { propilítica com } \\
\text { adulária }\end{array}$ & Propylitic & $\begin{array}{l}\text { Cristalização de } \\
\text { clorita, epidoto, } \\
\text { calcita, fluorita, } \\
\text { albita, adulária, } \\
\text { quartzo, actinolita, } \\
\text { pirita, calcopirita e } \\
\text { ouro em veios, } \\
\text { vazios ou } \\
\text { substituindo minerais } \\
\text { pré-existentes }\end{array}$ & $\begin{array}{l}\text { Clorita + albita }+ \\
\text { epidoto + carbonato } \\
\pm \text { pirita } \pm \text { óxido de } \\
\text { ferro e em menor } \\
\text { quantidade sericita. }\end{array}$ & $\begin{array}{c}\text { Epidoto, albita, } \\
\text { clorita, septoclorita, } \\
\text { carbonato, sericita, } \\
\text { pirita, óxidos de ferro } \\
\text { e menos comumente, } \\
\text { zeólitas e } \\
\text { montmorilonita }\end{array}$ & $\begin{array}{l}\text { - Quartz- } \\
\text { chlorite-pyrite } \\
\text { - Propilica }\end{array}$ \\
\hline $\begin{array}{l}\text { Alteração } \\
\text { argílica }\end{array}$ & Argillic & $\begin{array}{c}\text { Cristalização de } \\
\text { minerais do grupo da } \\
\text { caolinita, calcedônia } \\
\text { e, localmente, } \\
\text { hematita e sericita } \\
\text { em veios ou } \\
\text { substituindo minerais } \\
\text { pré-existentes }\end{array}$ & $\begin{array}{l}\text { Minerais do grupo da } \\
\text { caolinita e da } \\
\text { smectita. Sericita não } \\
\text { é típica mas pode } \\
\text { estar presente }\end{array}$ & $\begin{array}{l}\text { Minerais do grupo da } \\
\text { caolinita e da } \\
\text { montmorilonita. } \\
\text { Argilas amorfas são } \\
\text { localmente } \\
\text { importantes. } \\
\text { Feldspato potássico } \\
\text { metaestável pode } \\
\text { estar presente e } \\
\text { biotita pode ser } \\
\text { parcialmente } \\
\text { substituída por } \\
\text { clorita }\end{array}$ & $\begin{array}{c}\text {-Argílica } \\
\text { intermediária }\end{array}$ \\
\hline
\end{tabular}

FIGURA 3 - Comparação entre as terminologias usualmente empregadas à sistemas hidrotermais e terminologia deste trabalho, compilada por Corrêa-Silva (2002).

No granito a albitização geralmente resultou na formação de bordas descontínuas de albita ao redor dos grãos de feldspato potássico, mas é também comum a cristalização de albita no interior do feldspato potássico, gerando texturas semelhante a pertitas, da qual difere por não seguir as direções cristalográficas do hospedeiro e por apresentar formas subeuhédricas. A albitização também ocorre a partir dos interstícios entre os minerais e em microfraturas, onde a 
albita hidrotermal tem formas subeuhédricas e, comumente, encontra-se intercrescida com quartzo anhedral. O quartzo associado a esta alteração é resultado de silicificação interstícial e fissural, tende a formas euhédricas nos veios, sempre tem albita associada e apresenta extinção ondulante e trilhas de inclusões fluidas bifásicas (gás-líquido) e monofásicas (sólidas).

A alteração sódica verificada no pórfiro é semelhante à que afetou o granito, com albita cristalizada ao redor de megacristais de feldspato potássico e de plagioclásio, formando bordas, por vezes descontínuas. Também ocorre preenchendo fraturas com formas tendendo a euhédricas, associada a quartzo anhedral.Ambos minerais também substituem a matriz do pórfiro.

\subsection{Metassomatismo Potássico}

O metassomatismo potássico, assim como o sódico, resulta da interação entre a rocha e os fluidos tardios produzidos pela cristalização de magmas, em temperaturas entre 800 e $300{ }^{\circ} \mathrm{C}$, mas a potassificação ocorre em temperaturas relativamente menores, às vezes já com participação de fluidos meteóricos (Hemley et al., 1980).

O metassomatismo potássico afetou o riolito porfirítico, o granito e os pórfiros nos estilos fissural e pervasivo e caracteriza-se pela pela substituição do feldspato potássico e da biotita do estágio magmático por feldspato potássico e biotita hidrotemais, e pela neoformação de feldspato potássico, biotita, quartzo e pirita. Esta alteração hidrotermal faz com que a rocha adquira cor vermelho-intenso devido, provavelmente, à exsolução do $\mathrm{Fe}^{3+}$ dos feldspatos e subseqüente cristalização de hematita como microinclusões, o que resulta em aspecto túrbido dos feldspatos ao microscópio.

No riolito porfirítico o metassomatismo potássico grada de fissural a pervasivo nas bordas de veios e o preenchimento final dos veios é dado por quartzo e feldspato potássico. Estes veios relacionam-se a fraturas orientadas regularmente ou não, neste caso, sugerindo origem por fraturamento hidráulico. Tipicamente observa-se substituição pervasiva dos megacristais e dos minerais da matriz por microclínio hidrotermal, quase sempre acompanhada pela cristalização de biotita, o que faz com que o feldspato potássico magmático adquira um aspecto pertítico. Freqüentemente o microclínio hidrotermal forma bordas nos megacristais de feldspato potássico que, por vezes, engloba restos da matriz, devido à cristalização acretiva. A biotita hidrotermal tem cor verde e é mais rara no riolito, ocorrendo localmente na matriz ou na borda de megacristais de feldspato potássico.

O metassomatismo potássico do riolito geralmente foi acompanhado por intensa silicificação da matriz, resultando na cristalização de quartzo anhedral a euhedrais quando sobre 
os fenocristais de quartzo bipiramidal. Vênulas de quartzo associadas à silicificação são comuns, formadas por quartzo anhedral que tende a euédrico nas bordas dos veios e tem associado feldspato potássico anhedral e pirita.

No granito foram identificados pelo menos dois eventos de alteração potássica, sendo o primeiro deles estritamente pervasivo e caracterizado pela substituição de felspato potássico ígneo por feldspato potássico hidrotermal, na maioria das vezes representado pelo microclínio, cristalizado nos interstícios entre os minerais ígneos e, localmente, envolvendo cristais de feldspato ígneo anteriormente manteados por albita hidrotermal. O feldspato potássico hidrotermal comumente está intercrescido com quartzo, que apresenta extinção ondulante e "nuvens" e trilhas de inclusões fluidas bifásicas (gás-líquido) e monofásicas (sólidas). Biotita de cor verde substitui a biotita magmática e preenche interstícios, com terminações em forma de cunha. Esta biotita, assim como a ígnea, foi quase que totalmente destruída pelas alterações subseqüentes, restando apenas relíquias locais.

O segundo evento de alteração potássica que afetou o granito foi fissural, com gradação para o estilo pervasivo. Sua cronologia relativa é dada pela superposição de veios e invasões pervasivas com microclina soperposta às texturas e mineralogia descritas anteriormente. $\mathrm{O}$ feldspato potássico presente nos veios está associado com quartzo e ambos são anhedrais e têm contatos serrilhados entre si.

O metassomatismo potássico nos pórfiros apresenta estilo pervasivo, resultando na substituição dos megacristais de felspato potássico ígneo por feldspato potássico hidrotermal que, localmente, forma bordas que englobam porções da matriz, que resta com inclusões, e confere aos megacristais aspecto esquelético. Quartzo e feldspato potássico substituíram também os minerais da matriz da rocha.

\subsection{Alteração Sericítica com Adulária}

A alteração sericítica ocorre devido ao progressivo decréscimo da temperatura dos fluidos hidrotermais e está diretamente relacionada à desestabilização química dos feldspatos. A liberação de $\mathrm{H}^{+}$pelo metassomatismo alcalino provoca uma redução da razão álcalis $/ \mathrm{H}^{+}$, induzindo então, a decomposição dos feldspatos em presença de $\mathrm{H}^{+}, \mathrm{OH}^{-}, \mathrm{K}$ e $\mathrm{S}$. As fases residuais das reações químicas são, em essência, quartzo, micas brancas (muscovita, paragonita, fengita, fuchsita e roscoelita) e pirita, que constiuem a paragênese característica da alteração sericítica (Meyer \& Hemley, 1967; Pirajno, 1992). Podem também estar presentes nesta associação calcopirita, molibdenita, rutilo e titanita.

Este tipo de alteração é o mais expressivo em volume e afeta todos os litotipos em 
diferentes intensidades, gradando para alteração potássica ou argílica.

A alteração sericítica no riolito ocorreu em estilo fissural e pervasivo, com gradação entre ambos estilos, onde claramente pode-se identificar as frentes de sericitização, que conferem à rocha coloração esbranquiçada. Característicamente as relações texturais indicam que a alteração sericítica sobrepõs-se ao metassomatismo sódico e potássico.

Onde a alteração é mais intensa, os megacristais de feldspato potássico e de plagioclásio foram totalmente substituídos por sericita, quartzo e adulária, resultando em textura pseudomórfica com coronas de quartzo, produto de sobras de reações químicas relativas à substituição dos feldspatos.

A adulária é predominantemente anhedral na matriz e tende a euhédrica nas bordas de veios e quando substitui megacristais. O quartzo deste evento de alteração é anhedral e apresenta trilhas de inclusões fluidas trifásicas, por vezes hipersalinas, concordantes com a direção do fluxo hidrotermal. Sericita, adulária e quartzo também substituem os minerais da matriz do riolito.

Associados aos veios da alteração sericítica, ocorre pirita euhédrica intercrescida com calcopirita em proporções variáveis. Também observam-se grãos de pirita e calcopirita anhedrais a subeuedrais esqueléticos dispersos na matriz, associadas com sericita e quartzo. Os cristais esqueléticos de sulfetos freqüentemente foram substituídos por hematita devido à evolução do estado de oxidação do sistema de redutor para oxidado, provavelmente devido à maior contribuição de fluidos meteóricos.

No granito a alteração sericítica grada de fissural a pervasiva, mas não provoca grandes alterações na cor da rocha, à exceção dos veios e nas suas proximidades, onde a rocha torna-se cinza. Ao menos dois eventos de sericitização foram identificados no granito, um relacionado ao resfriamento dos fluidos finais da colocação do corpo ígneo, e o outro relacionado a zonas de cisalhamento.

No primeiro evento os feldspatos foram substituídos por sericita, quartzo e adulária, tanto em veios como pervasivamente. Neste caso a adulária é anhedral, mas tende a euhédrica nas bordas dos veios, albita hidrotermal ocorre associada, cristalizada a partir do excesso de $\mathrm{Na}^{+}$ gerado pela decomposição do plagioclásio, e estão presentes também pirita, calcopirita e calcocita.

A sericitização associada ao cisalhamento distingue-se da anterior pela orientação dos minerais da associação quartzo + sericita + pirita segundo a foliação milonítica e pela ausência de adulária.

Nos pórfiros a sericitização confere à rocha coloração acinzentada e apresenta-se em 
estilo fissural e pervasivo, sobrepondo-se à alteração sódica, potássica e propilítica. Nas porções mais alteradas, os megacristais de feldspato potássico e plagioclásio encontra-se totalmente substituídos por sericita, quartzo e adulária e restos de biotita magmática e do metassomatismo potássico já cloritizadas são substituídas por sericita neste estágio da alteração hidrotermal. A matriz dos pórfiros foi também intensamente afetada pela alteração sericítica com adulária, estando associados veios de quartzo com adulária, sericita, pirita, calcopirita, molibdenita e ouro.

Nos tufos, ignimbritos, tufitos, rochas vulcanoclásticas e sedimentos a alteração sericítica afetou volumes maiores de rocha, devido a maior permeabilidade e, conseqüentemente, a mineralização não restringe-se às zonas de veios e fraturas. A sericita associada ao quartzo, adulária, pirita e calcopirita substitui a matriz dos tufos, tufitos e sedimentos com estrutura de fluxo do fluido, que evolui para uma brecha hidrotermal. Esta brechação foi controlada por fluidos que fragmentaram a rocha devido ao aumento da pressão de fluido.

Com a evolução da alteração e aumento da fugacidade de oxigênio, provavelmente relacionada com maior aporte de fluidos meteóricos, ocorreu substituição de pirita por hematita e, no final, a sílica em excesso precipitou em veios sob a forma de quartzo, reaproveitando antigos condutos dos fluidos hidrotermais.

\subsection{Alteração Propilítica com Adulária}

A alteração propilítica com adulária, caracterizada pela assembléia clorita + carbonato + epídoto + fluorita + albita + hornblenda + adulária + calcopirita + pirita + leucoxênio + rutilo + barita, é o segundo tipo mais abundante de alteração que afetou o sistema hidrotermal. Cronologicamente dois eventos foram identificados. O primeiro, que relaciona-se aos fluidos emanados/mobilizados pela cristalização do magma granítico, antecede a alteração sericítica com adulária. Este evento afetou os corpos de andesito, de riolito e parte dos tufos, e tem estilo principalmente pervasivo. O segundo evento altera todos os litotipos, tem estilo, em essência, fissural, é posterior à alteração sericítica e vincula-se à colocação dos diques de pórfiro e dacito.

Nos corpos de riolito o primeiro evento a cloritização foi mais expressivo e é marcado pela substituição quase que total da biotita magmática e hidrotermal por clorita, leucoxênio, rutilo e pirita, além da substituição de megacristais e bordas de plagioclásio e de felspato potássico por clorita + carbonato + fluorita + epidoto e clorita. Pirita e calcopirita euhédricas com microvênulas de ouro estão comumente associadas à clorita, que também preenche vesículas, pequenas cavidades e microfraturas, onde comumente apresenta-se sob a forma agregados em roseta ou irregulares. Muitas vezes a matriz do riolito foi também intensamente substituída por uma fina "massa" de clorita, carbonatos, fluorita, epídoto e sulfetos. 
O segundo evento de propilitização que afetou o riolito tem associados clorita, quartzo, epídoto, carbonatos, fluorita, albita, pirita, calcopirita e adulária, que ocorrem predominantemente como preenchimento de veios, com alteração dos minerais ao redor (Foto 1). Os veios cortam as assembléias minerais da sericitização e do primeiro estágio de propilitização e nestes veios a clorita forma agregados e rosetas e está intercrescida com pirita e calcopirita subeuhédricas. O quartzo, localmente da variedade ametista, tende a ser euhédrico nas paredes do veio, com linhas de crescimento marcadas por inclusões. A fluorita é também euhédrica e concentra-se nas bordas dos veios, geralmente com adulária associada, que também tem forma anhedral que tende a euhédrica nas paredes dos veios. A albita é euhédrica e está inclusa em carbonato intersticial, que é a última fase cristalizada nos veios (Foto 2). Esta mesma paragênese substituiu os minerais adjacentes aos veios, o que indica gradação do estilo fissural para pervasivo neste estágio evolutivo do sistema hidrotermal.

Nos derrames de andesito a propilitização ocorreu em estilo fissural a pervasivo e provocou a substituição da hornblenda ígnea por actinolita hidrotermal acicular, juntamente com plagioclásio, clorita, epídoto, clinozoisita e carbonatos, e da biotita por clorita e titanita. Clorita, epídoto, clinozoisita e carbonato estão associados à hornblenda hidrotermal nos veios, assim como ao plagioclásio alterado, do qual derivam. Onde a alteração hidrotermal é mais intensa, a substituição do plagioclásio pode ser total, restando apenas agregados pseudomórficos dos minerais hidrotermais. A clorita também substituiu o plagioclásio e a biotita, este quase que totalmente, restando apenas algumas relíquias, e preencheu vesículas e interstícios entre os grãos de plagioclásio e hornblenda magmáticos.

Nos tufos a alteração propilítica é marcada por intensa cloritização da matriz que, em algumas porções da rocha, associa-se a brechas de fraturamento hidráulico com superposição de fraturamento crítico, segundo a classificação de Jébrak (1997). Sulfetização acompanha a cloritização da matriz dos tufos, com cristalização de pirita e calcopirita em cristais variando de subeuhédricos esqueléticos a euhédricos. Em testemunhos de sondagens observa-se que a propilização foi mais intensa nas proximidades do granítico e em maior profundidade. Em direção à superfície há uma gradativa redução da alteração e o seu estilo passa de pervasivo a fissural. 


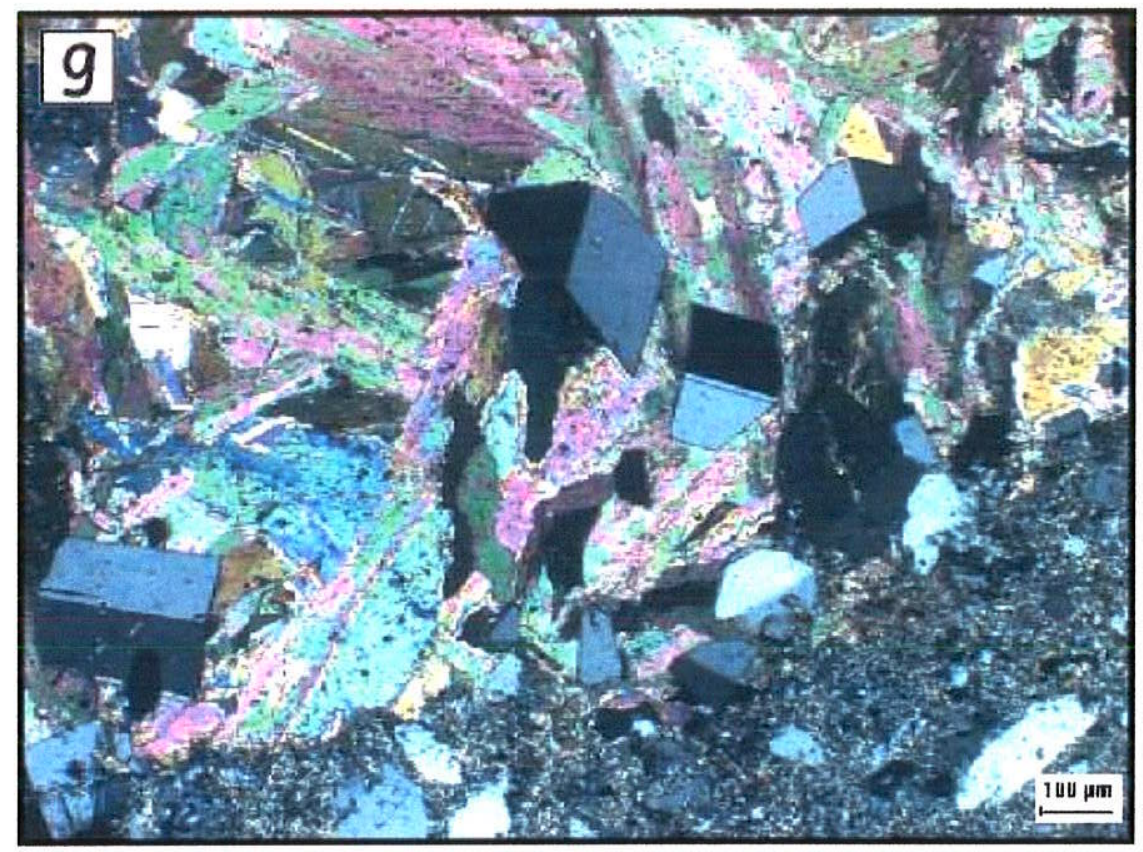

FOTO 1 - Propilitização em estilo fissural, com veio preenchido por clorita, fluorita, calcita e adulária, com albita euhédrica.

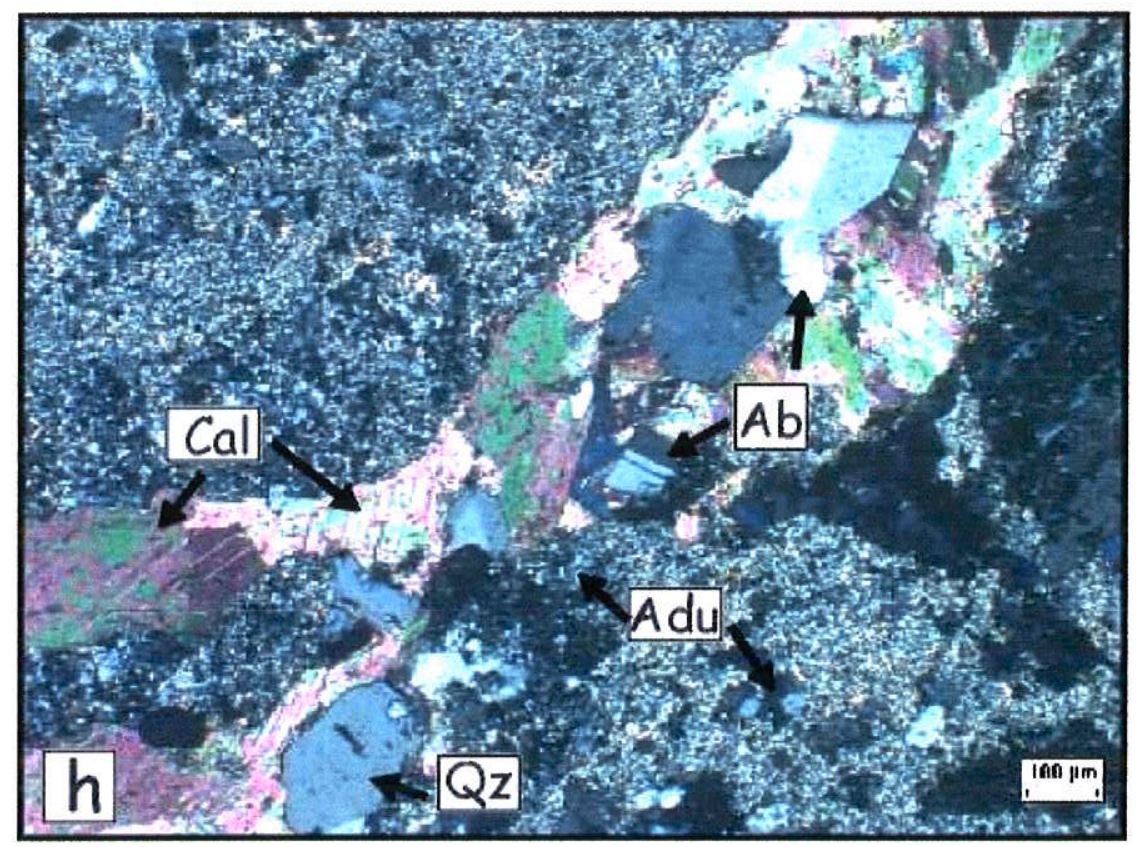

FOTO 2 - Veio de alteração propilítica com quartzo, albita, adulária, calcita e clorita.

No granito o primeiro evento de alteração foi predominantemente pervasivo, provocando a total substituição da biotita clorita, leucoxênio, pirita e rutilo. $\mathrm{O}$ feldspato potássico e o plagioclásio foram substituídos por clorita, epídoto, fluorita, barita e carbonatos, principalmente em seus núcleos de composições mais cálcicas. O segundo evento de propilitização foi predominantemente fissural, gradou para pervasivo e é muito semelhante ao segundo evento que afetou o riolito, sugerindo que sua origem pode estar relacionada aos fluidos hidrotermais 
associados aos diques de pórfiro. A assembléia mineral é formada por clorita, quartzo, epídoto, carbonato, adulária, plagioclásio, pirita e calcopirita. No segundo evento o feldspato potássico e o plagioclásio magmático e hidrotermal foram substituídos gradativamente a partir de microfraturas e clivagens por clorita, carbonato, fluorita e epidoto. A clorita forma agregados com hábito de roseta ou irregulares intercrescidos com quartzo e sulfetos. Albita euhédrica, está presente principalmente em veios, imersa no carbonato ou associada a adulária. A adulária é predominantemente anhedral, mas tende a euhédrica nas paredes dos veios e quando é produto da substituição do feldspato potássico. A fluorita é freqüentemente euhédrica e ocorre associada à clorita, carbonatos e epídoto, ou em veios tardios da propilitização, onde está em paragênese com pirita, calcopirita e ouro. Silicificação tardia provoca a substituição por sílica amorfa de cristais placóides de calcita, hábito este descrito em sistemas geotermais atuais relacionados a ambiente epitermal low-sulfidation de zonas de ebulição (boiling), como o de BroadlandsOhaaki (Nova Zelândia) descrita por Simmons \& Browne (2000).

Nos sedimentos a alteração propilítica ocorre em estilo predominantemente fissural, com clorita associada a epídoto, carbonato, fluorita, adulária, pirita e calcopirita. Estes minerais preenchem veios e alteram clastos de feldspato potássico, plagioclásio e, principalmente, a matriz da encaixante, deixando a rocha com coloração esverdeada, principalmente nas descontinuidades, como no acamamento.

Nos diques de pórfiros a alteração propilítica é predominantemente pervasiva, apresentando localmente fraturas preenchidas por clorita, epídoto, carbonato, fluorita, adulária, albita, quartzo, calcopirita, pirita e ouro. A assembléia de propilitização superpõs-se ao metassomatismo potássico e foi seguida pela a alteração sericítica. A alteração propilítica confere à rocha cor verde-intenso provocada pela substituição da matriz por uma massa fina constituída por clorita, epídoto, carbonatos, fluorita, quartzo, adulária, albita, pirita e calcopirita. Os megacristais de plagioclásio também foram afetados pela propilitização e apresentam os núcleos substituídos por clorita e epídoto e as bordas preservadas pela propilitização, de cor vermelha, produto da substituição do plagioclásio por microclínio durante o metassomatismo potássico. A biotita magmática e a cristalizada pelo metassomatismo potássico foram quase que totalmente substituídas por clorita na propilização. Nos veios a clorita tende a formar rosetas, mas, geralmente, ocorre sob a forma de agregados, intercrescida com quartzo, carbonatos, fluorita, pirita e calcopirita. A calcopirita e a pirita encontram-se intercrescidas e o ouro associase a elas na forma de microvênulas.

Os diques de dacito foram afetados pela alteração propilítica em estilo fissural que grada a pervasivo. Neste evento a hornblenda magmática foi substituída por actinolita e clorita, 
gerando textura coronítica, mas também pode formar veios e preencher interstícios entre os grãos. O plagioclásio tem seus núcleos substituídos por clorita, epídoto e clinozoisita e suas bordas localmente com cristalização acretiva de oligoclásio e albita. $\mathrm{O}$ epídoto e a clinozoisita associam-se à hornblenda hidrotermal nos veios e preenchem interstícios da rocha, localmente formando bolsões de epidoto, onde é comum a presença de calcita.

\subsection{Alteração Argílica}

A alteração argílica corresponde ao último evento hidrotermal que afetou o sistema vulcanossedimentar estudado. Este tipo ocorre nas porções superiores do pacote e afetou principalmente o riolito, tufos, ignimbritos e tufitos. Esta alteração resulta principalmente na decomposição dos feldspatos para argilominerais, como a caolinita, ilita, montmorilonita, dickita, haloisita e halofana, e é produzido por intensa lixiviação ácida, em intervalos de temperatura que variam entre 100 e $300{ }^{\circ} \mathrm{C}$ (Pirajno, 1992).

No riolito a alteração argílica foi principalmente fissural, onde são verificados veios de caolinita com cristais centimétricos. $\mathrm{O}$ estilo da alteração grada para pervasivo ao redor dos veios, conferindo à rocha coloração esbranquiçada.

Tipicamente observa-se que os minerais da matriz do riolito e os megacristais de feldspato potássico e de plagioclásio ígneos e hidrotermais foram parcial a quase que totalmente substituídos por minerais do grupo da caolinita, em evento acompanhado por silicificação tardia. A sericita também é substituída por caolinita, tanto nos veios como ao redor destes.

Nos tufos, ignimbritos e tufitos a alteração argílica grada de fissural, com veios preenchidos por minerais do grupo da caolinita, a pervasiva, onde os argilominerais substituem a matriz das rochas e parte dos fragmentos de feldspato potássico e plagioclásio. Houve ainda superposição de um evento de sericitização ao de argilização, com cristalização de sericita fina disseminada. A sericitização tardia foi produzida pelo aumento da atividade de potássio no fluido, provocada pela sucessão de pulsos de fluidos hidrotermais que provocam um local e discreto aumento da temperatura e a recarga de potássio no sistema. O fluido novamente enriquecido em potássio, ao atingir as zonas da rocha que estão sendo silicificadas, pode ter reagido com o $\mathrm{Al}^{3+}$ e o excesso de sílica produzidos pela quebra da caolinita e precipitou sericita.

Entretanto, considerando- que o $\mathrm{Al}^{3+}$ é relativamente mais imóvel que a sílica em soluções aquosas, esperaria-se a cristalização de pirofilita a partir da quebra da caolinita, segundo a reação de Hemley et al. (1980): 


$$
\text { caolinita }+6 \mathrm{H}^{+}=\text {pirofilita }+2 \mathrm{Al}^{3+}+4 \mathrm{H}_{2} \mathrm{O}
$$

Para que esta reação possa ocorrer, o fluido tem que atingir elevados valores de acidez, o que é típico de sistemas do tipo high-sulfidation (ou quartzo-alunita) onde é comum a deposição de pirofilita e sílica amorfa nos estágios de alteração argílica avançada.

A ausência de pirofilita no sistema aqui estudado, pode ser explicada pelo diagrama da Fig. 4, que mostra a curva de saturação de quartzo no campo de estabilidade da caolinita, em temperaturas inferiores a $200{ }^{\circ} \mathrm{C}$, para o sistema $\mathrm{Al}_{2} \mathrm{O}_{3}-\mathrm{SiO}_{2}-\mathrm{H}_{2} \mathrm{O}$ à pressão de água de $1 \mathrm{kbar}$. Neste caso, a falta da pirofilita pode ser devida à redução da atividade da sílica, resultando em um sistema situado abaixo da linha de saturação em quartzo e/ou por reaquecimento provocado pela reintrodução de fluidos mais aquecidos, que favorecem intersecção das reações químicas em uma trajetória aproximadamente horizontal, favorecento a cristalização da caolinita ou do diásporo em detrimento da pirofilita.

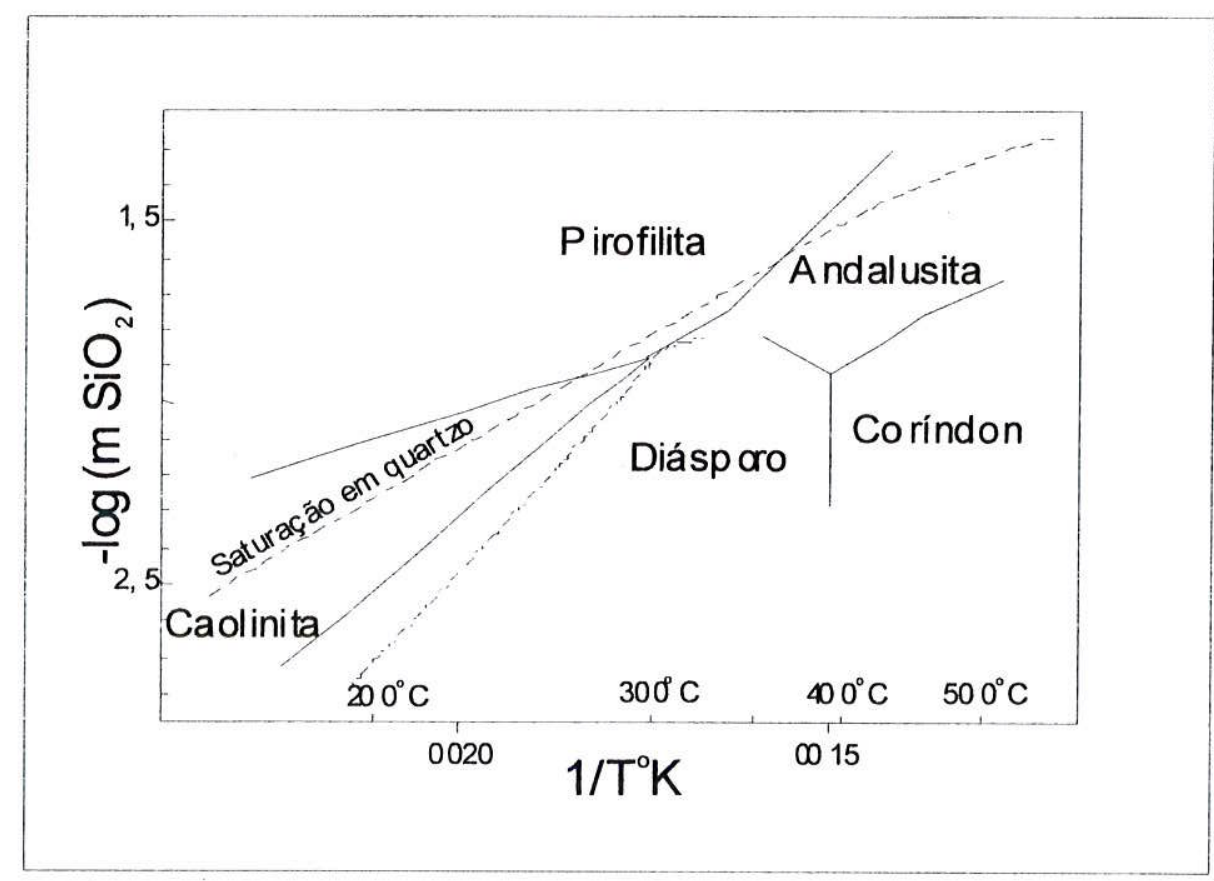

FIGURA 4 - Relações de estabilidade no sistema $\mathrm{Al}_{2} \mathrm{O}_{3}-\mathrm{SiO}_{2}-\mathrm{H}_{2} \mathrm{O}$, a 1 kbar de $\mathrm{H}_{2} \mathrm{O}$. Modificado de Hemley et al. (1980)

\section{CONCLUSÕES}

$\mathrm{O}$ evento hidrotermal precoce reconhecido nos corpos de granito e de pórfiro da área estudada foi o metassomatismo sódico, caracterizado pela substituição dos feldspatos ígneos por albita. Com a queda da temperatura e enriquecimento em potássio no fluido hidrotermal, o metassomatismo sódico evoluiu para potássico nos granitos e pórfiros e, pervasivamente afetou os derrames de riolito porfirítico mais proximais e em fissuras nos mais distais. 
A alteração hidrotermal predominante no sistema estudado é a sericítica, com adulária, representada pela associação sericita + quartzo + pirita + calcopirita + molibdenita, que afetou todos os litotipos estudados nos estilos fissural e pervasivo. Dois eventos de sericitização foram identificados, o primeiro provocado pelos fluidos finais da colocação do granito e dos pórfiros e o segundo relacionado com zonas de cisalhamento.

O segundo tipo de alteração em volume que afetou o sistema vulcanossedimentar estudado foi a alteração propilítica com adulária, com clorita + carbonato + epídoto + fluorita + albita + hornblenda + calcopirita + pirita + leucoxênio + rutilo + barita associados. Este tipo de alteração ocorreu principalmente em estilo pervasivo e, subordinadamente, em estilo fissural e afetou todos os litotipos. O primeiro evento de propilitização, anterior a sericitização, relacionase à colocação do granito e afetou os derrames de andesito e de riolito e parte dos tufos. A ocorrência de calcita placóide substituída por sílica amorfa e calcedônia neste evento de alteração é típica de sistemas epitermais do tipo adulária-sericita.

O segundo evento vincula-se com a colocação dos corpos de pórfiro e dacito e são posteriores à primeira alteração sericítica. A pressão e a temperatura deste evento de alteração estimada varia entre 1,5 e 0,2 kbar e 410 e $350{ }^{\circ} \mathrm{C}$ (Corrêa-Silva, 2002), o que é coerente para o ambiente vulcânico associados aos sistemas geotermais, responsáveis pelo desenvolvimento de extensas zonas de alteração hidrotermal com sistemas low- e high-sulfidation e de pórfiros $\mathrm{Cu}-\mathrm{Au}$ ou $\mathrm{Cu}-\mathrm{Mo}$.

O último evento de alteração hidrotermal vulcanogênico que afetou o sistema foi a alteração argílica, restrita aos litotipos que ocorrem nas porções superiores do sistema hidrotermal.

O segundo evento de sericitização foi controlado pelas estruturas rúpteis das zonas de cisalhamento mais tardias que, característicamente, distingue-se do anterior, por não apresentar adulária em sua assembléia mineral.

Todo o conjunto mostra-se mineralizado em ouro, cobre e molibdênio, mas os maiores teores estão relacionados com as alterações propilítica e sericítica, especialmente nas bordas e internamente aos diques de pórfiro riolítico e riodacítico.

Segundo Hayba et al. (1985), o controle estrutural regional mais comum para os depósitos do tipo low-sulfidation é ao longo de margens de caldeiras abatidas, que propiciam um excelente sistema de condutos para os fluidos hidrotermais, como no caso aqui estudado.

Muitas caldeiras localizam-se ao longo de importantes zonas de falhas que estiveram intermitentemente ativas antes e depois do ciclo da caldeira (Rytuba, 1994). A reativação destas estruturas nos estágios finais do ciclo das caldeiras, comumente controlam a colocação dos 
sistemas de vents máficos e félsicos que estão geneticamente relacionados aos sistemas hidrotermais das caldeiras.

Os tipos, padrões, distribuição e superposição da alteração hidrotermal, as mineralizações e forma de ocorrência da mineralização estudada, assim como as características anteriores, permite identifica-la como gerada em um sistema epitermal low-sulfidation, ou adulária-sericita, hospedado nas rochas vulcânicas e vulcanoclásticas e subvulcânicas ácidas distribuídas na borda de uma caldeira gerada no Paleoproterozóico.

Este sistema epitermal desenvolveu-se nos estágios finais da fase sin- a pós-abatimento da caldeira, quando da colocação em superfície dos domos riolíticos e ignimbritos, e em subprofundidade, quando da intrusão sucessiva de corpos graníticos rasos e diques de pórfiros, responsáveis pela reativação das células convectivas.

Adulária já havia sido identificada na Província Aurífera do Tapajós por Dreher et al. (1998), associada à veios de quartzo em rochas básicas da Suíte Intrusiva Ingarana e foi sugerido por estes autores, sua possível correlação a sistemas epitermais semelhantes ao aqui descrito. Entretanto as associações de sistemas epitermais low-sulfidation com rochas básicas, segundo White \& Hedenquist (1990), são muito raras sendo que na maioria dos casos estão associados à magmatismo intermediário a ácido, podendo ocorrer raramente em suítes vulcânicas bimodais. Nos casos de sistemas epitermais low-sulfidation hospedados em rochas básicas, estas rochas tem afinidades shoshoniticas ou alcalinas. A idade do sistema descrito por Dreher et al. (1998) é significativamente mais antigo que o aqui descrito indicando pelo menos dois eventos hidrotermais de baixa temperatura e com fluidos reduzidos na Província Aurífera do Tapajós, o mais antigo relacionado com zonas de cisalhamento e diques máficos encaixados em granitos mesozonais, que pode relacionar-se aos depósitos intrusion-related descritos por Santos et al. (2001), e outro mais novo, vulcanogênico, aqui descrito, que constitui um típico depósito lowsulfidation, exceto pela sua idade. 


\section{CAPÍTULO VII CONSIDERAÇÕES FINAIS}

Com base nos artigos e nas discussões apresentadas, podem ser feitas as seguintes consideerações:

\section{METALOGÊNESE DO OURO E DE METAIS DE BASE}

A Província Aurífera do Tapajós insere-se no contexto geológico da Província Tapajós-Parima, cuja orogênese ocorrida entre 2,10 e 1,87 Ga resultou na formação da associação metavulcano-sedimentar do Grupo Jacareacanga e de quatro arcos magmáticos cálcio-alcalinos, representados pelo Complexo Cuiú-Cuiú ( 2,01 Ga), pela Suíte Intrusiva Creporizão (1.974 a $1.957 \pm 6 \mathrm{Ma})$, o Tonalito Rio das Tropas $(1.895 \pm 7 \mathrm{Ma})$ e pela Suíte Intrusiva Parauari ( 1,88 Ga) (Santos et al., 2000; 2001). Posteriormente, desenvolveu-se o magmatismo anorogênico Uatumã $(\sim 1,87 \mathrm{Ga})$, representado pela Suíte Intrusiva Maloquinha, à qual associa-se o vulcanismo intermediário a ácido do Grupo Iriri latu sensu. Neste contexto, inclui-se ainda as vulcânicas da Formação Moraes Almeida, correlata ao Grupo Iriri, as vulcânicas mais antigas, denominadas Formação Vila Riozinho, e as vulcânicas subalcalinas a alcalinas (Dall'Agnol et al., 1999; Lamarão et al., 1999; no prelo).

Seqüências fluviais e marinhas rasas da Formação Buiuçu, depositadas em bacias tafrogênicas proterozóicas, recobrem as vulcânicas do Grupo Iriri e os granitos Maloquinha (Bezerra, 1984; Faraco et al., 1997).

Vários episódios de magmatismo básico e lamprofírico são reconhecidos na Província em $\sim 1.879 \mathrm{Ma}$ (Suíte Ingarana), 1.778 Ma (Diabásio Crepori), 1.536 Ma (Lamprófiro Jamanxim), 1.042 a $1.090 \mathrm{Ma}$ (Suíte Intrusiva Cachoeira Seca) e diques indiferenciados, com idades variando entre 514 e 134 Ma. (Santos \& Loguércio, 1984; Quadros et al., 1999; Almeida et al., 2000; Bahia \& Quadros, 2000; Santos et al., 2000; 2001).

Seqüência sedimentares Paleozóicas e Cenozóicas e coberturas aluvionares e lateríticas recentes completam o quadro geológico regional.

A maioria das lavras de ouro da Província Aurífera do Tapajós foram feitas em aluviões e rochas alteradas, mas com o esgotamento dos depósitos secundários, várias pesquisas foram desenvolvidas visando os depósitos primários. As mineralizações secundárias e primárias de ouro mostram um estreito relacionamento com os granitos do Supergrupo Uatumã (Silva, 1982; Faraco et al., 1997), mas são também encontradas em rochas máficas da Suíte Ingarana, em sedimentos proterozóicos e, menos comumente, nas vulcânicas do Grupo Iriri.

A diversidade litotípica e geocronológica das hospedeiras das mineralizações, seus 
estreitos vínculos com zonas de cisalhamento de direção predominante NW-SE e as formas anastomosadas dos veio quartzo, geralmente delgados e sulfetados, permitem inferir que o principal metalocteto aurífero da Província relaciona-se às zonas de cisalhamento. Sua gênese é mesotermal e são de níveis crustais relativamente profundos, o que tem sugerido baixa potencialidade de ocorrências nas rochas vulcânicas do Grupo Iriri (Coutinho et al., 1997; Faraco et al., 1997; Klein, 1999; Santos et al., 2001).

Estão presentes ainda depósitos mesotermais orogênicos, intrusion-related gold systems e epitermais associados a zonas de cisalhamento, granitos e intrusivas básicas (Santos et al., 2001, Dreher et al., 1998).

Entretanto os novos tipos de mineralizações aqui estudados indicam também alto potencial para ocorrência de depósitos epitermais filoneanos de alto teor e volumes relativamente pequenos, e de depósitos do tipo pórfiro, com teores baixos e grandes volumes na Província Aurífera do Tapajós. Estas mineralizações estão hospedadas em unidades vulcano-plutônicas, cujo embasamento é constituído predominantemente por granodioritos e granitos foliados da Suíte Intrusiva Parauari, recoberto por vulcânicas e vulcanoclásticas do Grupo Iriri que, por sua vez são cortadas por granitos tardi- a pós-tectônicos, granófiros e pórfiros riodacíticos e riolíticos que relacionam-se ao evento Parauari, e granitos anorogênicos da Suíte Intrusiva Maloquinha.

As vulcânicas e vulcanoclásticas compõem duas seqüências, cuja gênese relaciona-se com a formação e evolução de complexos de caldeiras vulcânicas.

A seqüência mais antiga é formada por rochas ígneas e vulcanoclásticas de composições andesíticas a dacíticas com basaltos subordinados na base e riolíticas no topo. Esta seqüência é truncada pelas caldeiras e é recoberta por ignimbritos, tufos diversos, cinzas vulcânicas, hialoclastitos e sedimentos vulcanoclásticos e terrígenos, que tambémpreenchem as caldeiras.

A seqüência tardia constitui vários vulcões compostos e domos riolíticos, aos quais associam-se as mineralizações epitermais em zonas de brechas hidrotermais de conduto.

As brechas de conduto encaixadas nos vulcões estão intensamente hidrotermalizadas por sistemas high-sulfidation, com alterações variando de propilítica, nas porções distais, a sericítica nas zonas mais profundas. Alterações argílica a argílica avançada de baixa a alta temperatura são verificadas no topo. Zonas de intensa alunitização e silicificação ocorrem nas partes centrais dos condutos de brechas hidrotermais, com vuggy silica e sílica maciça, além de alunitização e silica cap oxidado no topo. Os dados de isótopos de enxofre em alunita e pirita indicam temperatura de formação variando de $330{ }^{\circ} \mathrm{C}$, em profundidade, até $140{ }^{\circ} \mathrm{C}$, no topo, e origem por fluidos magmáticos, com pequena influência de água meteórica. A esta mineralização associam-se típicos minerais de sistemas epitermais high-sulfidation, como a enargita-luzonita e a 
woodhousenita-svanbergita (que indica origem por fluidos magmáticos), juntamente com pirita, calcopirita, bornita, covellita, galena, esfalerita e ouro e prata nativos.

As mineralizações formadas pelos sistemas low-sulfidation ocorrem em contexto geológico semelhante ao das mineralizações high-sulfidation, mas em sub-províncias diferentes, e são caracterizadas pela associação sericita-adulária, superposta a zonas de alteração propilítica e sericítica, em rochas vulcânicas ácidas. Nestas rochas ocorrem mineralizações de ouro, pirita, calcopirita, bornita e molibdenita. Na partes mais profundas das estruturas vulcânicas ocorrem diques de pórfiros riolíticos a dacíticos afetados por metassomatismo potássico e propilitização, geneticamente relacionadas às alterações epitermais. São também comuns corpos circunscritos de monzogranito subvulcânicos com fortes alterações hidrotermais, iniciadas com metassomatismo sódico, que evoluiu para metassomatismo potássico, alterações propilíticas e sericíticas, em estilos e arranjos semelhantes à evolução das alterações de alta a baixa temperatura em pórfiros mineralizados em $\mathrm{Cu}$ e $\mathrm{Au}$.

Granitos com alterações semelhantes às verificadas nos granitos associados aos sistemas epitermais foram estudados no Garimpo do Batalha, onde foi deduzida barometricamente uma colocação mais profunda que os associados às mineralizações epitermais e composição do fluido hidrotermal, baseada nos halógenos da biotita, muito semelhante aos de pórfiros mineralizados em $\mathrm{Cu}-\mathrm{Au}$. A evolução fluidal, deduzida pelas paragêneses hidrotermais destes granitos é muito semelhante, conforme pode ser verificado na Fig 1.

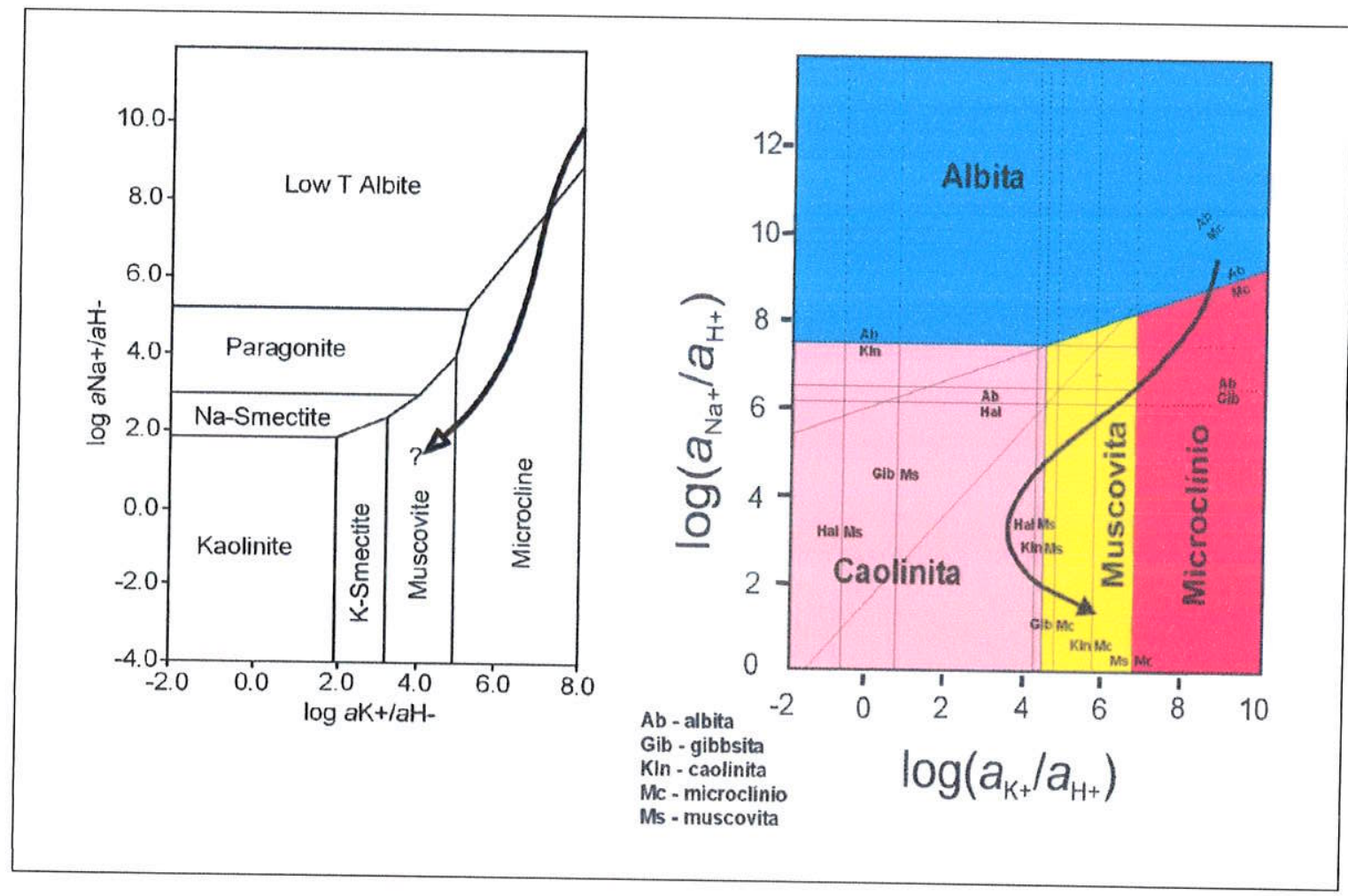

FIGURA 1 - Evolução fluidal do sistema hidrotermal do Granito Batalha (Corrêa-Silva et al., 2000) à esquerda, e na mineralização low-sulfidation (Corrêa-Silva, 2002), à direita. 
Assim, granitos e granófiros cálcio-alcalinos relacionados aos estágios tardios de desenvolvimento do arco magmático Parauari, especialmente os associados à evolução dos complexos de caldeiras e à formação dos depósitos epitermais, podem apresentar grande potencial para ocorrência de mineralizações de grande volume e baixo teor de $\mathrm{Cu}-\mathrm{Au}$ ou $\mathrm{Mo}$.

Desta forma, além dos metaloctetos bem conhecidos, associados a rochas básicas, granitos, sedimentos e zonas de cisalhamento, devem ser considerados como alvos potenciais para prospecção de ouro e de metais de base em sistemas epitermais filoneanos high- e lowsulfidation no Grupo Iriri latu sensu, em zonas oxidadas, hematíticas, associadas a zonas de silica cap.

Assim, os estudos iniciais desenvolvidos na Província Aurífera do Tapajós permitem o estabelecimento preliminar da evolução metalogenética da região, com a possível conecção entre os sistemas hidrotermais plutônicos e vulcanogênicos, à semelhança do verificado em ambientes tectônicos mesozóicos e cenozóicos (Perelló, 1994; Hedenquist et al., 1998; Love et al., 1998) entre outros, o que implica em alto potencial para ocorrência de depósitos de pórfiros de $\mathrm{Cu}-\mathrm{Au}$ e Cu-Mo na Província Aurífera do Tapajós. Como conseqüência, estas descobertas constituemse em importante contribuição ao estudo da metalogênese de metais preciosos e de base em terrenos cratônicos antigos, especialmente no continente africano.

As zonas de cisalhamento com depósitos mesotermais, apesar dos retrabalhamentos posteriores, podem, neste contexto evolutivo, representar as raízes de condutos dos fluidos hidrotermais mais profundos e, potencialmente, podem ser hospedeiras de depósitos filonianos maiores, especialmente onde sua evolução vincula-se com a formação das caldeiras e dos sistemas epitermais.

Uma vez que os depósitos epitermais foram erodidos por sistemas de leques aluviais e fluviais durante o abatimento das caldeiras, há também potencial para ocorrência de depósitos de ouro em paleo-placers, possivelmente representado na mineralização verificada em Castelo dos Sonhos (Araneda et al., 1998).

A preservação dos sistemas epitermais pode vincular-se com a formação de bacias pullapart, desenvolvidas durante a atividade vulcânica que, como indica a existência de abundantes corpos de hialoclastito pode ter sido, em parte, desenvolvido em ambiente subaquático. Assim, a evolução do ambiente fluvial para marinho raso pode, potencialmente, ter possibilitado a formação de depósitos exalativos disseminados e de sulfetos maciços e metais de base em sedimentos de ambiente mais calmo, ou em caldeiras submersas.

Há, entretanto, necessidade para os trabalhos de prospeç̧ão mineral, de uma melhor caracterização das seqüência vulcânicas, uma vez que hoje são já reconhecidos pelo menos dois 
eventos importantes de formação de rochas vulcânicas em 2,00 e 1,88 Ga, bem como da estratigrafia e da evolução de cada unidade, com distinção dos eventos pré-, sin- e pós-caldeira.

É também fundamental o estudo da deformação e do metamorfismo no limite SW da Província, para caracterização da subdução proposta por Tassinari (1986) e Santos et al. (2000), que poderá permitir o estabelecimento das relações da granitogênese, das vulcânicas e dos sistemas epitermais com os períodos tardi- pós-colisionais ou intracratônicos e anorogênicos. Adicionalmente, a definição das trajetórias metamórficas, por estudos geotermobarométricos, poderá ser essencial para a caracterização do tipo da colisão e do regime termal da crosta, contribuindo, desta forma, para melhor definição do potencial metalogenético da Província.

\section{ESTRATIGRAFIA DAS VULCÂNICAS}

Com o avanço dos estudos, as vulcânicas e vulcanoclásticas do Cráton Amazônico tem sido gradativamente subvididas, sendo reconhecidas unidades relativamente mais novas a sul da Serra do Cachimbo e outras mais antigas, como Formação Vila Riozinho no Tapajós (Lamarão et al., 1999; no prelo).

Estas subdivisões são, em essência, geocronológicas, mas a litologia tem permitido a subdivisão do Grupo Iriri latu sensu em uma unidade vulcanoclástica (Formação Aruri), que recobre os riolitos da Formação Salustiano. Alguns autores inserem ainda neste Grupo as vulcânicas andesíticas da Formação Bom Jardim e há também unidades correlatas, como a Formação Moraes de Almeida.

A evolução de um complexo de caldeiras, como exemplificado nos estudos de Aguirre Dias \& McDowell (2000) e Juliani et al. (Submetido), é, sinteticamente, iniciada com a construção de estratovulcões, geralmente, com uma unidade basal vulcânica básica e/ou andesítica, que grada para derrames riolíticos intercalados em tufos de cinzas (atividade précaldeira). Com a formação da caldeira, grandes volumes de tufos de cinzas recobrem extensas áreas (atividade sin-caldeira) e, por fim há o desenvolvimento de vulcões anelares, radiais ou internos, compostos por cinzas e/ou lavas, bem como por domos riolíticos resurgentes (atividades sin- a pós- e intra-caldeira) e depósitos epiclásticos. Em complexos de caldeiras (nested calderas), como as interpretadas no Tapajós, o desenvolvimento de caldeiras próximas e superpostas, leva à interdigitação de lavas e de fluxos piroclásticos num espaço de tempo que pode alcançar algumas dezenas de milhões de anos. Isto pode fazer com que datações pontuais, sem o reconhecimento químico e faciológico das vulcânicas e vulcanoclásticas, não separem as formações, e sim as aglutinem em unidades híbridas, o que implicaria na necessidade de mapeamentos faciológicos e geoquímicos.

As unidades do Grupo Iriri latu sensu aparentam ser associações litotípicas que podem 
pertencer a diversas formações vulcanogênicas, o que implicaria na redefinição da estratigrafia em vigor. Isto é especialmente factível pelas extensões superiores a $50 \mathrm{~km}$ sugeridas para os complexos de caldeiras do Tapajós, e pela sua possível formação em região de back-arc ou de intra-arc, com subdução de oeste para leste, o que implicaria, potencialmente, na migração do arco vulcânico para leste, com gradativa redução da idade das vulcânicas. Assim, a distribuição das formações podem ser também definidas por um forte controle estrutural, definido pelas zonas de rifts alinhados aproximadamente paralemente à zonas de subducão, que controlam a formação dos complexos de caldeiras. Note-se, neste contexto, que zonas de falhas no Tapajós orientam-se segundo noroeste-sudeste, mas possíveis paleo-rifts orientam-se segundo lesteoeste, o que poderia sugerir uma geometria diferente da atualmente admitida para a zona de subducção da Província Tapajós-Parima.

Os estudos preliminares ora apresentados permitem concluir que o início da atividade vulcânica na Província Aurífera do Tapajós foi marcado por extensos derrames de andesito, seguidos pela erupção de grande volume de magma riolítico e fluxos ignimbríticos, responsáveis pela formação de estratovulcões, além de domos riolíticos. Esta fase seria correspondente à fase pré-caldeira, representada pelas rochas da Seqüência Inferior.

A fase seguinte desenvolveu-se com a erupção de um grande volume de material piroclástico, ignimbritos e riolito, que provocam a exaustão da câmara magmática e, conseqüente, colapso da caldeira, produzindo rápida descompressão e ebulição dos voláteis que provocaram a erupção explosiva de magmas ricos em cristais, através de falhas, fraturas anelares e vents. Esta atividade foi responsável pela formação dos extensos depósitos de tufos de cristais descritos na região estudada.

O magmatismo recorrente foi responsável pela formação de pequenos vulcões e vents associados a falhas e fraturas anelares distribuídos principalmente na borda da caldeira e, em menor volume, internamente à caldeira. Neste vulcões e vents ocorreu a extrusão de magma riolítico e vulcanismo explosivo, resultando na geração dos depósitos ignimbríticos, de tufos e de tufos soldados estratificados com os riolitos. Estes vents também desenvolveram-se ao longo de zonas de falhas transcorrentes e em zonas distensivas ao redor da caldeira, possivelmente com seu desenvolvimento relacionado ao final da segunda orogênese da Província (Santos et al., 2000).

O magmatismo ressurgente foi também responsável pela formação de domos riolíticos dentro da caldeira, associado também a pequenas estruturas circulares que podem estar relacionadas com a intrusão de stocks dos pórfiros riolíticos e riodacíticos.

A depressão da caldeira foi, desde sua formação, preenchida por tufos, tufito, arenito epiclástico e sedimentos. $\mathrm{O}$ retrabalhamento subaquático dos sedimentos $\mathrm{e}$ rochas 
vulcanoclásticas, a silicificação diagenética, a deposição de leitos silica (cherts) e a presença de ritmitos indica que houve aprisionamento de água na caldeira, possivelmente formando um lago. Neste contexto, a deposição de chert pode ser relacionada a processos exalativos, produto da atividade hidrotermal remanescente, ou produzida pelas últimas intrusões de diques de pórfiros.

A colocação de stocks e plútons de granófiros aproveitaram os vents do vulcanismo e foram, por fim, cortados por diques de pórfiro e de dacito, responsáveis pela intensa alteração hidrotermal estudada.

O tipo de caldeira encontrado (ash-flow calderas) ocorre sobre uma crosta continental, mas segundo os dados disponíveis sobre a Província Aurífera Tapajós, rochas do embasamento na região das caldeiras não foram ainda reconhecidas, mas deveriam ser representadaspor uma crosta mais antiga, ou por rochas dos arcos magmáticos pré-Parauri.

\section{IMPLICAÇÕES TECTÔNICAS}

A formação das caldeiras dependem do regime tectônico, da localização em relação aos limites das placas e do tipo da crosta.

As caldeiras são divididas em dois grupos principais, as formadas por atividade explosiva, associada a ambientes epicontinentais e arcos de ilhas, e as subsidentes, formadas em escudos basálticos. As geradas por atividades explosivas tem, nos estágios iniciais, abundante vulcanismo andesítico, derivado da fusão parcial de placa oceânica em subducção de baixo ângulo sob o continente. Neste contexto, os dacitos e riolitos são normalmente derivados da fusão parcial da crosta continental em contato com magma basáltico em zonas distensivas, ou por diferenciação do magma do plúton ou do batólito subjacente à caldeira. Ao entrar em colapso são produzidos enormes erupções de ignimbritos, que cobrem extensas áreas.

Os magmas são usualmente cálcio-alcalinos, raramente alcalinos e, tipicamente compõem suites bimodais.

Todas estas características estão presentes na Província Aurífera do Tapajós, e faltam extensiva atividade vulcano-sedimentar relacionada com arcos de ilhas. Os sedimentos paleo- a mesoproterozóicos são depósitos continentais predominante fluviais e marinhos rasos, com ortoarenitos e arenitos feldspáticos, indicando área fonte continental. As formas alongadas das bacias sedimentares, comumente limitadas por falha (ver Fig. 2, Capítulo I) e as grandes espessuras dos sedimentos, sugerem uma origem tafrogênica, como destacado por diversos autores.

Desta forma, o conjunto dos dados geológicos sugere que os depósitos vulcanogênicos do Grupo Iriri sensu latu, foram formados em crosta siálica continental, em em zonas convergentes de placas tectônicas, em ambiente tectônico muito semelhante aos cenozóicos onde instalam-se 
ash-flow calderas.

As semelhanças dos granitos com pórfiros reforça esta interpretação, pois os pórfiros de cobre restringem-se a arcos de ilhas e a margens continentais de limites convergentes de continente-placa oceânica e, tipicamente, são pós-colisionais (Sillitoe, 1973; Müller, 2000).

A preservação do edifício vulcânico na Província Aurífera do Tapajós significa que o ambiente tectônico foi extensional, diferentemente do que ocorrem em arcos de ilhas, onde os estratovulcões e as caldeira são soerguidos e rapidamente erodidos (Fisher \& Schmincke, 1994).

Busby-Spera (1988) propõe que os estratovulcões e as caldeiras mesozóicas do Arizona, Califórnia e oeste de Nevada formaram-se em regime distensivo relacionado a uma bacia de intra- a back-arc originada pela subdução da placa do Pacífico sob o continente norte-americano, em ambiente tectônico semelhante ao verificado com o arco de grabens e às depressões atuais, que encerram as atividades vulcânicas e de caldeiras ainda em atividade. Uma das características deste ambiente é que, devido aos diferentes processos de fusão, relacionados à subdução e à distensão local, ocorrem intercalações de vulcânicas alcalinas e calcio-alcalinas. Estas intercalações ainda não foram constatadas no Tapajós, mas a contemporaneidade, ou quase, do magmatismo está bem estabelecida, bem como a presença de vulcâncias alcalinas e calcioalcalinas, o que sugere ambiente tectônico de back- ou de intra-arc em 1,86 Ga na Província Aurífera do Tapajós, conforme sistetizado na Fig. 2.

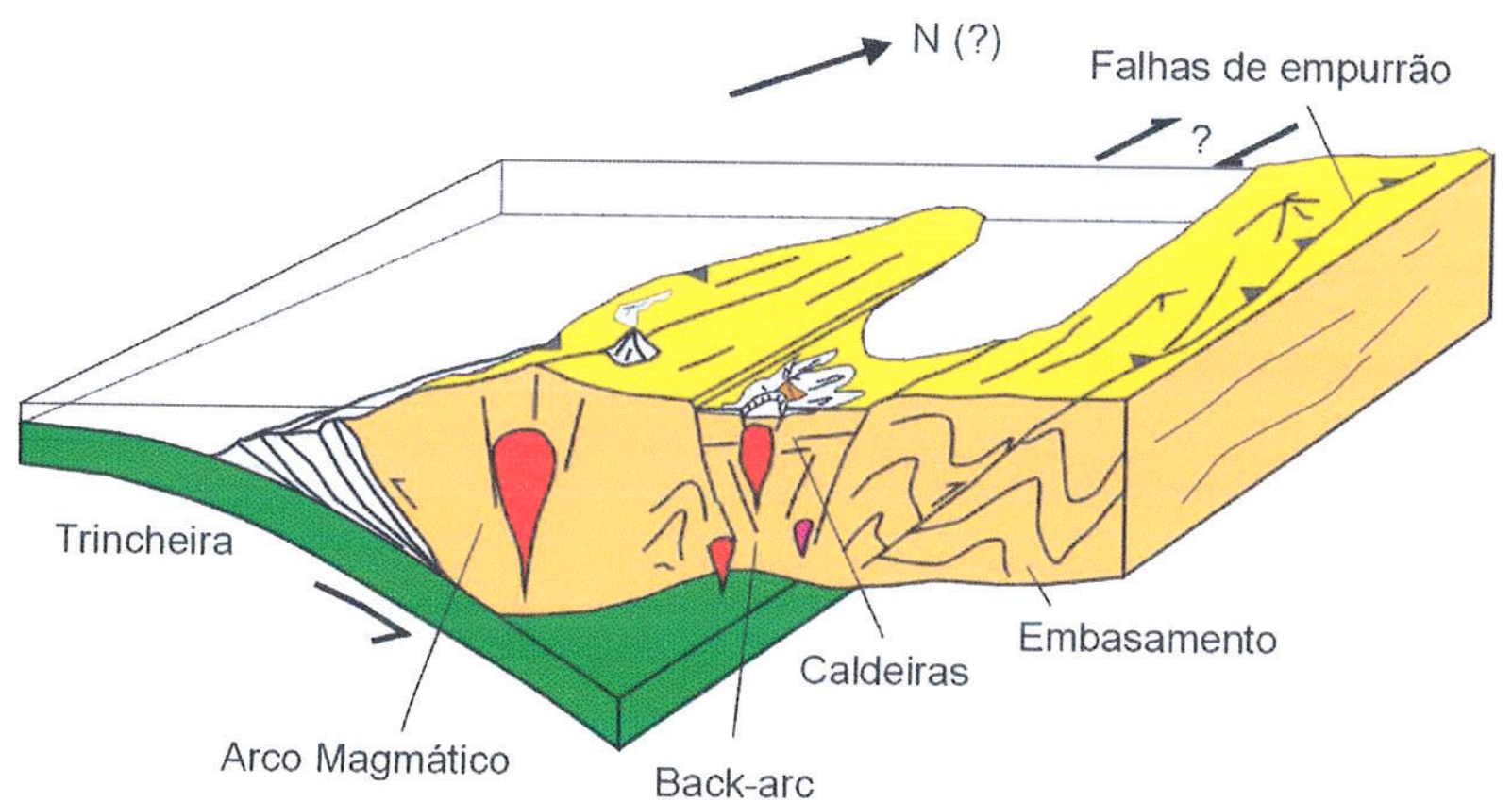

FIGURA 2 - Esquema de formação das ash-flow calderas na Província Aurífera do Tapajós a $1,86 \mathrm{Ga}$, com os vulcões anelares que hospendam as mineralizações high-e low-sulfidation.

Neste contexto, há necessidade de reavaliação dos esquemas evolutivos propostos para a 
região da Província Aurífera Tapajós, uma vez que nos modelos atuais os períodos acrescionários dos arcos vulcânicos coincidem com os períodos de forte distensão. Novos modelos evolutivos devem considerar a natureza do embasamento das caldeiras, ainda não identificada e, sobretudo, deveriam explicar o significado, ainda pouco compreendido, da preservação das mineralizações em relação à sucessão de regimes compressionais, sem que tenha havido soerguimento, cavalgamentos e erosão das estruturas vulcânicas. Deve ainda ser notado que estas mineralizações situam-se nas proximidades do limite entre as província Tapajós-Parima e Central Amazônica, onde o modelo de acresção e colagem dos arcos de ilhas (Tassinari, 1996) e magmáticos (Santos et al., 2000), o que impossibilitaria a preservação das mineralizações estudadas, devido à compressão tectônica. Assim, o sistema vulcano-plutônico estudado, poderia representar uma atividade magmática posterior ao evento Ventuari-Tapajós ou Tapajós-Parima. 


\section{REFERÊNCIAS BIBLIOGRÁFICAS}

ABDEL-RAHMAN, A.F.M. (1994) Nature of biotites from alkaline, calc-alkaline and peraluminous magmas. J. Petrol., 35(2): 525-541.

AGUIRRE DIAS, G.J.; MCDOWELL, F.W. (2000) Volcanic evolution of the Amelco caldera, central Mexico. In: H.D. GANADOS, G.J. AGUIRRE Dias \& J.M. Stock (Ed), Cenozoic tectonics and volcanism of Mexico. Special Paper. Geological Society of America, Boulder, $275 \mathrm{p}$.

ALMEIDA, C.A.S.; COLLYER, T.A.; PEREIRA, J.L.; SEABRA, A. S.; FURTADO, A.M. M.; SOUBÉS, L.F. (1977) Relatório final de reconhecimento (1). Projeto SantarémCachimbo-pesquisa Mineral. Pólo Amazônia/Pólo Tapajós. Convênio SUDAM/IDESP.

ALMEIDA, F.F.M. de (1978) A evolução dos Crátons Amazônico e São Francisco comparada com a de seus homólogos do Hemisfério Norte. In: Congr. Bras. Geol., 30. Recife, Anais, 6: 2393-2399.

ALMEIDA, F.F.M. de; HASUI, Y.; BRITO NEVES, B.B. (1976) The upper Precambrian of South America. Boletim do Instituto de Geocências, v. 7, p. 45-80

ALMEIDA, F.F.M. de; HASUI, Y.; BRITO NEVES, B.B. de; FUCK, R.A. (1981) Brazilian Structural Provinces: an introduction. Earth Sci. Rev., (17): 1-29.

ALMEIDA, M.E.; BRITO, M.F.L.; FERREIRA, A.L.; MONTEIRO, M.A.S. (2000) Geologia e recursos minerais da Folha Mamãe Anã (SB.21-V-D). Estados do Amazonas e Pará. Escala 1:250.000. PROMIM Tapajós, CPRM, Brasília, Brazil [CD-ROM].

ALMEIDA, M.E.; BRITO, M.F.L.; MACAMBIRA, M.J.B. (1999a) Caroçal Granite: ${ }^{207} \mathrm{~Pb} /{ }^{206} \mathrm{~Pb}$ zircon evaporation age in post-colisional granitoids of Tapajós Gold Province, Amazonian Region, Brazil. In: South American Symposium on Isotope Geology, 2, Buenos Aires, 1999. Actas., p. 3-6

ALMEIDA, M.E.; FERREIRA, A.L.; BRITO, M.F.L.; MONTEIRO, M.A.S. (1999b) Proposta de evolução tectono-estrutural para a região do médio-alto curso do Rio Tapajós (Estado do Pará e Amazonas). In: Simpósio de Geologia da Amazônia, 6, Manaus, 1999. Anais. Manaus, SBG/Nucleo Norte. p. 297-300.

ALMEIDA, M.E.; FERREIRA, A.L.; BRITO, M.F.L.; MONTEIRO, M.A.S.; POPINI, M.V.F. (1998) Mineralizações auríferas associadas a vulcanismo ácido a intermediário na Folha Vila Mamãe Anã, Provincia Mineral do Tapajós. In: Congresso Brasileiro de Geologia, 40., Belo Horizonte, 1998. Anais. Belo Horizonte, SBG/NMG, p. 148.

ANDERSON, J.L. \& SMITH, D.R. (1995) The effects of temperature and $\mathrm{fO}_{2}$ on the Al-inhornblende barometer. Am. Mineral., (80): 549-559.

ANDREW, C.J. (2002) The Chelopech Au deposit, Bulgaria. http://www.huxley.ic.ac.uk/research/basins/wilkinson/mdsg/webpages/mdsgabs/andrew 1. htm

ARANEDA, R.; LIZ, J.C.; MADALOSSO, A.; ANDRADE, P.; OLIVEIRA, G. (1998) Características geológicas e natureza das mineralizações auríferas de alguns prospectos da Província do Tapajós - PA. In: Congresso Brasileiro de Geologia, 40. Anais..., SBG/MG, Belo Horizonte, p. 144.

ARRIBAS JR., A. (1995) Characteristics of high-sulfidation epithermal deposits, and their relation to magmatic fluid. In: J.F.H. THOMPSON (Ed), Magmas, fluids and ore deposits. Miner. Assoc. Can. Short Course, 23: $41 \overline{9} 454$. 
ARRIBAS JR., A.; CUNNINGHAM, C.G.; RYTUBA, J.J.; RYE, R.O.; KELLY, W.C.; PODWYSOCKI, M.H.; MCKEE, E.H.; TOSDAL, R.M. (1995) Geology, geochronology, fluid inclusions, and isotope geochemistry of the Rodalquiar Gold Alunite Deposits, Spain. Econ. Geol., 90: 795822.

ASHLEY, R.P. \& SILBERMAN, M.L. (1976) Direct dating of mineralization at Goldfield, Nevada, by potassium-argon and fission-track methods. Econ. Geol., 71: 904-924.

ASHLEY, P.M. \& ANDREW, A.S. (1992) The Mt. Ninderry acid sulphate alteration zone and its relation to epithermal mineralization in the North Arm Volcanics, Southeast Queensland. Australian Journal of Earth Sciences, 39(1): 79-98.

AYUSO, R.A.; WOODEN, J.L.; Foley, N.K.; SEAL, R.R.; SINHA, A.K.; PERSING, H. (in press) UPb zircon (SHRIMP-RG) ages and $\mathrm{Pb}$ isotope geochemistry of gold deposits in the Carolina Slate Belt. Econ. Geol.

BAHIA, R.B.C. \& QUADROS, M.L.E.S. (2000) Geologia e recursos minerais da Folha Caracol (SB.21-X-C). Estado do Pará Escala 1:250.000. PROMIM Tapajós, CPRM, Brasília, Brazil [CD-ROM].

BALLENTINE, C.J. (1997) Resolving the mantle $\mathrm{He} / \mathrm{Ne}$ and crustal ${ }^{21} \mathrm{Ne} /{ }^{22} \mathrm{Ne}$ in well gases. Earth and Planetary Science Letters, 152: 233-249.

BARD, J.P. (1986) Microtexttures of igneous and metamorphic rocks. Dordrecht, D. Reidel, $264 \mathrm{p}$.

BERGER, B.R. (1986) Descriptive model of epithermal quartzalunite Au. In: D.P. COX \& D.A. SINGER (Eds), Mineral deposit models. U.S. Geol. Surv. Bull., 1693: 1158.

BERGER, B.R. \& HENLEY, R.W. (1989) Advances in the understanding of epithermal gold̃silver deposits - with special references to deposits of the western United States. In: R. KEAYS, R. RAMSAY and D. GROVES (Eds), The geology of gold deposits: the perspective in 1988. Econ. Geol. Monograph., 6: $40 \tilde{5} 423$.

BERMAN, R.G. (1988) Internally-consistent thermodynamic data for stoichiometric minerals in the system $\mathrm{Na}_{2} \mathrm{O}-\mathrm{K}_{2} \mathrm{O}-\mathrm{CaO}-\mathrm{MgO}-\mathrm{FeO}-\mathrm{Fe}_{2} \mathrm{O}_{3}-\mathrm{Al}_{2} \mathrm{O}_{3}-\mathrm{SiO}_{2}-\mathrm{TiO}_{2}-\mathrm{H}_{2} \mathrm{O}-\mathrm{CO}_{2} . \quad J$.
Petrol. 29: $445-522$.

BERMAN, R.G. (1991) Thermobarometry using multiequilibrium calculations: a new technique with petrologic applications. Can. Mineral., 29: 833-855.

BETTENCOURT, J.S. \& DALL'AGNOL, R. (1987) The Rondonian Tin-bearing Anorogenic granites and associated mineralization. In: International Symposium on Granites and Associated Mineralizations. CBPM/Superintendência de Geologia e Recursos Minerais, Salvador, Excursion Guides, 49-87.

BETTENCOURT, J.S.; TOSDAL, R.M.; LEITE, W.B.; JR, P.B.L. (1995) Overview of the rapakivi granites of the Rondônia Tin Province (RTP). In: Symposium on rapakivi granites and related rocks, excursion guide: The rapakivi granites of the Rondônia Tin Province and asssociated mineralization. J.S. BETTENCOURT \& R. DALL'AGNOL (Ed). Centro de Geociências, Universidade Federal do Pará, Brasil.

BEZERRA, P.E.L. (1984) Cronoestratigrafia das coberturas sedimentares proterozóicas do Cráton Amazônico e seu relacionamento com o Supergrupo Uatumã (Amazônia Legal). $33^{\text {th }}$ Congr. Bras. Geol., SBG/RJ, Rio de Janeiro, Brazil, Anais, 5: 21252139.

BIRD, M.I.; CHIVAS, A.R.; MCDOUGALL, I. (1990) An isotopic study of surficial alunite in Australia 2. Potassium-argon geochronology. Chemical Geology (Isotope Geoscience Section, 80: 133-145. 
BIZINELLA, G.A.; SANTIAGO, A.F.; SANTOS, A.; BORGES, F.R.; SOUZA, F.J.C.; GODOY, H.K.; YAMAGUTI, H.S.; OLIVEIRA, J.R.; OLIVEIRA, R.L. (1980) Projeto Tapajós-Sucurundi. CPRM/DNPM, 1(B).

BONHAM JR, H.F. (1984) Three major types of epithermal precious metal deposits. Geol. Soc. Am. Abstr. Progr., 16: 449.

BONHAM JR., H.F. (1986) Models for volcanic-hosted epithermal precious metal deposits: A review. In: International Volcanological Congress. Proc. Symposium, New Zealand, 13-17.

BOONE, G.M. (1969) Origin of clouded feldspars: petrologic contrasts in a granitic porphyry intrusion. Am. J. Sci., 267: 633-668.

BORODINA, N.S.; FERSHTATER, G.E.; VOLTYAKOV, S.L. (1999) The oxidation ratio of iron in coexisting biotite and hornblende from granitic and metamorphic rocks: the role of $\mathrm{P}, \mathrm{T}$ and $f\left(\mathrm{O}_{2}\right)$. Can. Mineral., 37: 1423-1429.

BOYNTON, W.V. (1984) Geochemistry of the rare earth elements: meteorite studies. In: HENDERSON, P. (Ed.), Rare earth element geochemistry. Elsevier, Amsterdam, p. 63114.

BRITO, M.F.L.; ALMEIDA, M.E.; FERREIRA, A.L.; MONTEIRO, M.A.S.; POPINI, M.V.F. (1997) Petrografia e litogeoquímica da Suíte Intrusiva Maloquinha - registro de magmatismo tipo A na Província do Tapajós. In: Congres. Bras. Geoquímica, I. Salvador, Anais, 847-851.

BROWN, G.C. (1982) Calc-alkaline intrusive rocks: their diversity, evolution, and relation to volcanic arcs. In: THORPE, R.S. (Ed.), Andesites - Orogenic andesites and related rocks. John Wiley \& Sons, Chichester, p. 437-461.

BURCHFIEL, B.G. \& DAVIS, G.A. (1972) Structural framework and evolution of the southern part of the Cordilleran orogen, western United States. American Journal of Science, 272: 97-118.

BURNARD, P.G. \& FARLEY, K.A. (2000) Calibration of pressure-dependent sensitivity and discrimination in Nier-type noble gas ion sources. Geochemistry, Geophysics, Geosystems (G3), [paper no.2000GC000038], v. 1, 10 p.

BUSBY-SPERA, C.J. (1988) Speculative tectonic model for the early Mesozoic arc of the southwest Cordilleran United States. Geology, 16: 1121-1125.

CANDELA, P.A. (1989) Felsic magmas, volatiles, and metallogenesis. In: WHITNEY, J.A., NALDRETT, A.J. (Eds), Ore deposits associated with magmas. Rev. Econ. Geol., 4: 223233.

CARITAT, P.; HUTCHEON, I.; WALSHE, J.L. (1993) Chlorite geothermometry: a review. Clay Clay Miner., 41(2): 219-239.

CATHELINEAU, M. (1988) Cation site occupancy in chlorites and illites as a function of temperature. Clay Miner., 23: 471-485.

CATHELINEAU, M. \& NIEVA, D. (1985) A chlorite solid solution geothermometer: the Los Azufres (Mexico) geothermal system. Contrib. Mineral. Petrol., 91: 235-244.

CORBETT, G.J. \& LEACH, T.M. (1998) Southwest Pacific rim gold-copper systems: structure, alteration, and mineralization. Soc. Econ. Geol. Spec. Publ., 6.

CORRÊA-SILVA, R.H. (2002) Caracterização de um sistema epitermal low̃ sulfidation

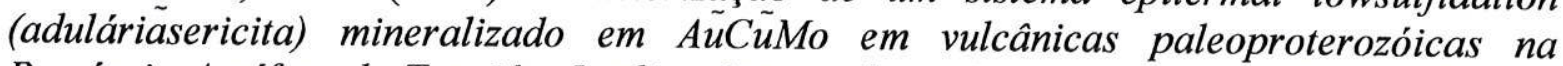
Província Aurífera do Tapajós: Implicações metalogenéticas e tectônicas. Master Thesis, Instituto de Geociências, Universidade de São Paulo, Brazil. 
CORREAA-SILVA, R.H.; JULIANI, C.; NUNES, C.D.M. (2000) Hydrothermal alteration gold mineralizations in rapakivi-like granite from Garimpo do Batalha, Tapajós Province, Amazon Craton, Brazil. $31^{\text {st }}$ Int. Geol. Congr. IUGS, CPRM, Rio de Janeiro, Brazil, Abstr. [CD-ROM].

CORRÊA-SILVA, R.H.; JULIANI, C.; BETTENCOURT, J.S.; NUNES, C.M.D.; ALMEIDA, T.I.R. (2001). Caracterização de um sistema epitermal low-sulfidation (ou adulária sericita) hospedado em vulcânicas e vulcanoclásticas do Grupo Iriri na Província Aurífera do Tapajós Pará. In: Simpósio de Geologia da Amazônia, 7. SBG/NN, Belém [CD ROM].

CORRÊA-SILVA, R.H.; JULIANI, C.; NUNES, C.M.D.; BETTENCOURT, J.S. (2000) Petrographic characterization of the hydrothermal alteration zones associated with gold mineralization in granitic rocks of the Batalha Gold Field, Tapajós (Pará), Brazil. Rev. Bras. Geoc., 30(2): 242-245.

COUTINHO, M.G.; DREHER, A.M.; MARINI, S. (1996) Controle das mineralizações de ouro da Província do Tapajós: resultados preliminares. In: Congres. Bras. Geol., 39, Salvador, Anais.

COUTINHO, M.G.; LIVERTON, T.; SOUZA, E.C. (1997) Granitic magmatism and related gold mineralization on the Tapajós Mineral Province, Amazonian Area, Brazil. $2^{\text {nd }}$ Int. Symp. Gran. Ass. Miner. Salvador, Brazil, Abstr. Progr., p. 46-47.

COUTINHO, M.G.; ROBERT, F.; SANTOS, R.A. (1998) Província Mineral do Tapajós, Amazônia, Brasil: novo enfoque geológico das mineralizações de ouro. In: Congres. Bras. Geol., 40, Belo Horizonte, Anais, p. 160.

COUTINHO, M.G.; LIVERTON, T.; SOUZA, E.C. (1997) Granitic magmatism and related gold mineralization on the Tapajós Mineral Province, Amazonian Area, Brazil. $2^{\text {nd }}$ Int. Symp. Gran. Ass. Miner. Salvador, Brazil, Abstr. Progr., p. 46-47.

DALL'AGNOL, R. (1980) Etudes sur des granites du type "Rondonian" en Amazonie Orientale et leurs transformations tardi-magmatiques. Doctorate Thesis, Univ. Paul Sabatier, Tolouse, France.

DALL'AGNOLL, R.; LAFON, J.M.; MACAMBIRA, M.J.B. (1994) Proterozoic anorogenic magmatism in the Central Amazonian Craton: Geochronological and geochemical aspects. Miner. Petrol., 50: 113138.

DALL'AGNOL, R.; PICHAVANT, M.; CHAMPENOIS, M. (1997) Iron-titanium oxide minerals of the Jamon Granite, Eastern Amazônian region, Brazil: implications for the oxigen fugacity in Proterozoic A - Type granites. Anais da Academia Brasileira de Ciências, 69: 325-347.

DALL'AGNOL, R.; RÄMÖ, O.T.; MAGALHÃES, M.S.; MACAMBIRA, M.J.B. (1999a). Petrologology of the anorogenic oxidised Jamon and Musa granites, Amazonian Craton: Implications for the genesis of Proterozoic A-type granites. Lithos, 46: 431-462.

DALL'AGNOL, R.; SILVA, C.M.G.; SCHELLER, T. (1999b) Fayalite-hedembergite rhyolites of Iriri Formation, Tapajós Gold Province, Amazonian Craton: implications for the Uatumã Volcanism. $1^{\text {st }}$ Simp. Vulc. Amb. Assoc., SBG, Gramado, Brazil, Bol. Res., p. 31.

DALRYMPLE, G.B.; ALEXANDER, E.C.; LANPHERE, M.A.; KRAKER, G.P. (1981) Irradiation of samples for ${ }^{40} \mathrm{Ar} /{ }^{39} \mathrm{Ar}$ dating using the Geological Survey TRIGA reactor: U.S. Geological Survey Professional Paper, 1176, 55 p.

DALRYMPLE, G.B.; CLAGUE, D.A.; GARCIA, M.O.; BRIGHT, S.W. (1981) Petrology and $\tilde{\mathrm{K}} \mathrm{Ar}$ of dredged samples from Laysan Island and Northampton Bank volcanoes, Hawaiian Ridge, and evolution of the Hawaiiañmperor chain. Geol. Soc. Am. Bull., 92: I315̃ 318 ; II884̃II933. 
DAMMER, D. (1995) Geochronology of chemical weathering processes in the northern and western Australian regolith. $\mathrm{PhD}$ dissertation, Australian National University, Canberra.

DAVIDSON, J. \& MPODOZIS, C. (1991) Regional geologic settings of epithermal gold deposits, Chile. Econ. Geol., 86: $117 \tilde{4} 1186$.

DE BRUYIN, H.; VAN der WESTHUIZED, W.A.; SCHOCH, A.E. (1983) The estimation of $\mathrm{FeO}, \mathrm{F}$ and $\mathrm{H}_{2} \mathrm{O}^{+}$by regression in microprobe analyses of natural biotite. J. Trace Microprobe T., 1(4): 399-413.

DERR, W.A.; HOWIE, R.A., ZUSSMAN, J. 1993. An Introduction to the rock-forming minerals. Hong Kong, Longman. 696 p.

DEYELL, C.L.; RYE, R.O.; LANDIS, G.P.; BISSIG, T. (2002) Alunite in an evolving magmatic hydrothermal system: the Tambo high sulfidation deposit, El Indio District, Chile. Chemical Geology, (in press).

DEYELL, C.L.; THOMPSON, J.F.H.; FRIEDMAN, R.M.; GROAT, L.A. (2000) Age and origin of advanced argillic alteration zones and related exotic limonite deposits in the Limonite Creek area, British Columbia. Can. J. Earth Sci., 37: 1093-1107.

DICKENSON, M.P. \& HEWITT, D. (1986) A garnet-chlorite geothermometer. Geol. Soc. Am. Abstr. Progr., 8(6): 584.

DREHER, A.M.; VLACH, S.R.F.; MARTINI, S.L. (1998) Adularia associated with epithermal gold veins in the Tapajós Gold Province, Pará State, northern Brazil. Rev. Bras. Geoc., 28(3): $397-404$.

DUBÉ, B.; DUNNING, G.; LAUZIÈRE, K. (1995) Geology of the Hope Brook Mine, Newfoundland, Canada: a preserved late Proterozoic high-sulfidation epithermal gold deposit and its implications for exploration. Econ. Geol., 93(4), 405-436.

EBY, G.N. (1990) A-Type granitoids: A review of thier occurrence and chemical characteristics and speculations on their petogenesis. Lithos, 26: 115-134.

EBY, G.N. (1992) Chemical subdivision of A-type granitoids: petrogenetic and tectonic implications. Geology, 20: 641-644.

FARACO, M.T.L.; CARVALHO, J.M.A.; KLEIN, E.L. (1997) Carta Metalogenética da Província Aurífera do Tapajós. In: COSTA, M.L.C. \& ANGÉLICA, R. S. (Eds.), Contrib. Geol. Amazônia. FINEP/SBG-NO, Belém, Brazil, p. 423-437.

FECHTIG, H. \& KALBITZER, S. (1966) The diffusion of argon in potassium-bearing solids. In: SCHAEFFER, O.A. \& ZAHRINGER, J. (Eds), Potassium Argon Dating. SpringerVerlag, p. 68-107.

FERREIRA, A.L.; ALMEIDA, M.E.; BRITO, M.F.L.; MONTEIRO, M.A.S. (2000) Geologia e recursos minerais da Folha Jacareacanga (SB.21-Y-B). Estados do Amazonas e Pará Escala 1: 250.000. PROMIM Tapajós, CPRM, Manaus, Brazil [CD-ROM].

FERSHTATER, G.B.; BORODINA, N.S.; CHASCHUKHINA, V.A. (1978) Ferrofacies of granitoids. Geokhimiya, 2: 147-160. (in Russian)

FIELDING, S.J. (1981) Crystal chemistry of the oxonium alunite-potassium alunite series. MS Thesis, Lehigh University.

FIELDING, S.J. \& SCLAR, C.B. (1980) The oxonium alunite-postassium alunite series; synthesis and characterization. Geological Society of America Annual Meeting, Atlanta, Abstract, 12(7): 425. 
FIFAREK, R.H.; RYE, R.O.; THRELKELD, R. Stable isotope systematics of the Pierina Au$\mathrm{Ag}$ Deposit, Peru: Implications for magmatic-hydrothermal processes in the epithermal acid sulfate environment. Chem. Geol. (in press).

FISHER, R.V. \& SCHMINCKE, H.-U. (1994) Volcaniclastic sediment transport and deposition. In: K. PYE (Ed) Sediment transport and depositional processes. Blackwell Scientific Publications, p. 351-388.

FLECK, R.J.; SUTTER, J.F.; ELLIOT, D.H. (1977) Interpretation of discordant ${ }^{40} \mathrm{Ar} /{ }^{39} \mathrm{Ar}$ age spectra of Mesozoic tholeiites from Antarctica. Geochimica et Cosmochimica Acta, 41: $15-32$.

FORMAN, J.H.A.; NARDI, J.I.S.; MARQUES, J.P.M.; LIMA, M.I.C. (1972) Pesquisa mineral no Iriri/Curuá. SUDAM/GEOMINERAÇÃO, Belém, 62 p.

FOURNIER, R.O. (1999) Hydrothermal processes related to movement of fluid from plastic into brittle rock in the magmatic-hydrothermal environment. Econ. Geol., 94: $119 \tilde{3} 1212$.

FUHRMAN, M.L. \& LINDSLEY, D.H. (1988) Ternary-feldspar modeling and thermometry. Am. Mineral. 73: 201-216.

LANDIS, G.P.; SNEE, L.W.; JULIANI, C. (in press) Evaluation of alunite argon ages and fluid inclusion integrity: step-wise noble gas heating experiments on $1.87 \mathrm{Ga}$ alunite from Tapajós Gold Province, Brazil. Chemical Geology.

GARZA, R.A.P.; TITLEY, S.R.; PIMENTEL, B.F. (2001) Geology of the Escondida porphyry copper deposit, Antofagasta region, Chile. Econ. Geol., 96: 307-324.

GOLDFARB, R.J.; GROVES, D.I.; GARDOLL, S. (2001) Orogenic gold and geologic time: a global synthesis. Ore Geol. Rev., 19: 1-75.

GRANT, J.A. (1986) The isocon diagram - a simple solution to Gresens' equation for metasomatic alteration. Econ. Geol., 81(8): 1976-1982.

GRESENS, R.L. (1967) Composition volume relations of metasomatism. Chem. Geol., 2(1): 47-65.

HALLBERG, A. (1994) The Enåesen gold deposit, Central Sweden: 1. A palaeoproterozoic high-sulphidation epithermal gold mineralization. Miner. Deposita, 29: 150-162.

HAMMARSTROM, J.M. \& ZEN, E.-A. (1986) Aluminum in hornblende: an empirical igneous geobarometer. Am. Mineral., 71: 1297-1313.

HARRIS, N.B.W.; PEARCE, J.A.; TINDLE, A.G. (1986) Geochemical characteristics of collision-zone magmatism. In: COWARD, M.P. \& REIS, A.C. (Eds.), Collision tectonics. Spec. Publ. Geol. Soc., 19: 67-81.

HARVEY, B.A.; MYERS, S.A.; KLEIN, T. (1999) Yanacocha Gold District, Northern Peru. PACRIM, '99, Bali, Indonesia, p. 445458.

HAYBA, D.O.; BETHKE, P.M.; HEALD, P.; FOLEY, N.K. (1985) Geologic, mineralogic, and geochemical characteristics of volcanic-hosted epithermal precious-metal deposits. Reviews in Economic Geology, 2: 129-168.

HEALD, P.; FOLEY, N.K.; HAYBA, D.O. (1987) Comparative anatomy of volcanic-hosted epithermal deposits: acid-sulfate and adulariasericite types. Econ. Geol., 82(1): 126.

HEDENQUIST, J.W. \& LOWENSTERN, J.B. (1994) The role of magmas in the formation of hydrothermal ore deposits. Nature, 370: 519527.

HEDENQUIST, J.W. (1987) Mineralization associated with volcanic-related hydrothermal systems in the Circum-Pacific Basin. In: M.K. HORN (Ed), Transactions of the Fourth 
Circum-Pacific Energy and Mineral Resources Conference, Singapore. Am. Assoc. Petr. Geol., p. 513524.

HEDENQUIST, J.W.; ARRIBAS JR., A.; REYNOLDS, T.J. (1998) Evolution of an intrusioncentered hydrothermal system: Far Southeast-Lepanto porphyry and epithermal $\mathrm{Cu}-\mathrm{Au}$ deposits, Philippines. Econ. Geol., 93: 373-404.

HEMLEY, J.J.; MONTOYA, J.W.; MARINENKO, J.W.; LUCE, R.W. (1980) Equilibria in the system $\mathrm{Al}_{2} \mathrm{O}_{3} \mathrm{SiO}_{2} \mathrm{H}_{2} \mathrm{O}$ and some general implications for alteration/mineralizations processes. Econ. Geol., 75: 210228.

HEMLEY, R.W. (1985) The geothermal framework of epithermal deposits. Reviews in Economic Geology, 2: 1-24.

HEY, M.H. (1954) A new review of the chlorites. Mineral. Mag., 30: 277-292.

HIBBARD, M.J. (1995). Petrography to petrogenesis. New Jersey, Prentice-Hall, 587 p.

HIYAGON, H.; OZIMA, M.; MARTY, B.; ZASHU, S.; SASAKI, H. (1992) Noble gases in submarine glasses from mid-oceanic ridges and Loihi seamount: constraints on the early history of the Earth. Geochimica et Cosmochimica Acta, 56: 1301-1316.

HONDA, M.; MCDOUGALL, I.; PATTERSON, D.B.; DOULGERIS, A.; CLAGUE, D.A. (1993) Noble gases in submarine pillow basalt glasses from Loihi and Kilauea, Hawaii: a solar component in the Earth.

HUNEKE, J.C. \& SMITH, S.P. (1976) The realities of recoil: ${ }^{39} \mathrm{Ar}$ recoil out of small grains and anomalous age patterns in ${ }^{40} \mathrm{Ar} /{ }^{39} \mathrm{Ar}$ dating: Proceedings of $7^{\text {th }}$ Lunar Science Conference, p. 1987-2008.

HUTCHINSON, C.S. (1974) Laboratory handbook of petrographic techinique. WileyInterscience Publication, New York, 527 p.

HYNES, A. (1980) Carbonatization and mobility of $\mathrm{Ti}, \mathrm{Y}$ and $\mathrm{Zr}$ in Ascot Formation metabasalts, SE Quebec. Contrib. Mineral. Petrol., 75(1): 79-87.

ISHIHARA, S. (1977) The magnetite-series and ilmenite-series. Min. Geol., 27: 293-305.

ISHIHARA, S. (1981) The granitoid series and mineralization. Econ. Geol. 75th Anniv. Vol., 458-484.

ISSLER, R.S.; ANDRADE, A.R.F; MONTALVÃO, R.M.G.; GUIMARÃES, G.; SILVA, G.G.; LIMA, M.I.L. (1974) Geologia. In: Projeto RADAMBRASIL. Folha SA.22. Belém. Rio de Janeiro, MME. p. 1-60 (Levantamento de Recursos Naturais, 5).

IXER, R.A. (1990) Atlas of opaque and ore minerals in their associations. Van Nostrand Reinhold, New York, 208 p.

JACOBI, P. (1999) The discovery of epithermal Au-Cu-Mo Proterozoic deposits in the Tapajós Province, Brazil. Rev. Bras. Geoc., 29: 277-279.

JAMBOR, J.L. (1999) Nomenclature of the alunite supergroup. Can. Mineral., 37: 1323̃1341.

JOHNSON, M.C. \& RUTHERFORD, M.J. (1989) Experimental calibration of the aluminiumin-hornblende geobarometer with application to Long Valley Caldera (California) volcanic rocks. Geology, 17: 837-841.

JOWETT, E.C. (1991) Fitting iron and magnesium into the hydrothermal chlorite geothermometer. GAC/MAC/SEG Join Ann. Meeting, Toronto, Canada, Progr. Abstr., 16: 62. 
JULIANI, C.; CORRÊA-SILVA, R.H.; MONTEIRO, L.V.S.; BETTENCOURT, J.S.; NUNES, C.M.D. (in press) The Aüranite Batalha system - Tapajós Gold Province, Amazonian Craton, Brasil: Hydrothermal alteration and regional implications. Precambrian Res.

JULIANI, C.; NUNES, C.D.N.; BETTENCOURT, J.S.; CORREAA-SILVA, R.H.; MONTEIRO, L.V.S.; NEUMANN, R.; ALCOVER NETO, A.; RYE, R.O. (2000) Early Proterozoic volcanic-hosted quartzalunite epithermal deposits in the Tapajós Gold Province, Amazonian Craton, Brazil. Geol. Soc. Am., Abstr. Progr. 32(7): A-49.

JULIANI, C.; RYE, R.O.; NUNES, C.M.D.; SNEE, L.W.; CORRÊA-SILVA, R.H.; MONTEIRO, L.V.S.; BETTENCOURT, J.S.; NEUMANN, R.; ALCOVER NETO, A. (2002) Paleoproterozoic high-sulfidation mineralization in the Tapajós Gold Province, Amazonian Craton, Brazil: geology, mineralogy, alunite argon age and stable isotope constraints. Chemical Geology, (in press).

JULIANI, C.; SZABÓ, G.A.; BENEVIDES, T.; FREITAS, F.C.; PÉREZ-AGUILAR, A. (2002) $G M G 332$ - Petrologia metamórfica - Versão preliminar. Departamento de Mineralogia e Geotectônica - GMG, Instituto de Geociências da USP, 171 p.

KENNEDY, B.M.; HIYAGON, H.; REYNOLDS, J.H. (1990) Crustal neon: a striking uniformity. Earth and Planetary Science Letters, 98: 277-286.

KERR, P.F. (1959) Optical mineralogy. New York, McGraw-Hill Book Company, Inc., 442 p.

KLEIN, E.L. \& VASQUEZ, M.L. (2000) Geologia e recursos minerais da Folha Vila Riozinho (SB.21-Z-A). Estado do Pará, Escala 1:250.000. PROMIM Tapajós, CPRM, Brasília, Brazil [CD-ROM].

KOUKHARSKY, M. \& MIRRE, J.C. (1976) Mi Vida prospect: A porphyry copper-type deposit in northwestern Argentina. Econ. Geol., 71: 849863

KRANIDIOTIS, P. \& MACLEAN, W.H. (1987) Systematics of chlorite alteration at the Phelps Dodge massive sulfide deposit, Matagami, Quebec. Econ. Geol., 8: 1888-1911.

KRETZ, R. (1973) Kinetics of the crystallization of garnet at two localites near Yellowknife. Can. Mineral., 12: 1-20.

LAMARÃO, C.N.; DALL'AGNOL, R.; LAFON, J.-M.; LIMA, E.F. (in press) Geology, geochemistry and $\mathrm{Pb}-\mathrm{Pb}$ zircon geochronology of the Paleoproterozoic magmatism of Vila Riozinho, Tapajós Gold Province, Amazonian Craton, Brazil. Precambrian Res.

LAMARÃO, C.N.; LAFON, J.M.; LIMA, E.F. (1999) As associações vulcânicas e plutônicas de Vila Riozinho e Morais Almeida, Província Aurífera do Tapajós, SW do Estado do Pará. In: $1^{\text {st }}$ Simp. Vulc. Amb. Assoc., SBG, Gramado, Brazil, Bol. Res., p. 93.

LANDIS, G.P. \& RYE, R.O. (2002) Preliminary study of gas chemistry and noble gas isotope ratios of fluids in alunite from diverse hydrothermal environments. Chemical Geology (in press).

LANG, J.R. \& BAKER, T. (2001) Intrusion-related gold systems: the present level of understanding. Miner. Deposita, 36: 477-489.

LEAKE, B.E.; WOOLLEY, A.R.; ARPS, C.E.S.; BIRCH, W.D.; GILBERT, M.C.; GRICE, G.D.; HAWTHORNE, F.C.; KATO, A.; KISCH, H.J.; KRIVOVICHEV, V.G., LINTHOUT, K.; LAIRD, J.; MANDARINO, J.; MARESCH, W.V.; NICKEL, E.H., ROCK, N.M.S.; SCHUMACHER, J.C.; SMITH, D.C.; STEPHENSON, N.C.N., UNGARETTI, L.; WITTAKER, E.J.W.; YOUZHI, G. (1997) Nomenclature of amphiboles. Report of Subcommittee on Amphiboles of the International Mineralogical Association Commission on New Minerals and Mineral Names. Eur. J. Mineral. 9(3): 623-651. 
LEVEILLE, R.A.; NEWBERRY, R.J.; BULL, K.F. (1988) An oxidation state-alkalinity diagram for discriminating some gold favorable plutons: an empirical and phenomenological approach. Geol. Soc. Am., Abstr. Progr., 20: A-142.

LIPPOLT, H.J. \& WEIGEL, E. (1988) ${ }^{4} \mathrm{He}$ diffusion in ${ }^{40} \mathrm{Ar}$-retentive minerals. Geochimica et Cosmochimica Acta, 52: 1449-1458.

LOTT, D.E. (2001) Improvements in noble gas separation methodology: a nude cryogenic trap.

LOTT, D.E. \& JENKINS, W.J. (1984) An automated cryogenic charcoal trap system for helium isotope mass spectrometry. Reviews of Scientific Instruments, 55: 1982-1988.

LOVE, D.A.; CLARK, A. H.; HODGSON, C. J.; MORTENSEN, J. K.; ARCHIBALD, D. A.; FARRAR, E. (1998) The timing of adularia-sericite-type mineralization and alunitekaolinite-type alteration, Mont Skukum Epithermal gold Deposit, Yukon Territory, Canada: ${ }^{40} \mathrm{Ar}-{ }^{39} \mathrm{Ar}$ and U-Pb geochronology. Economic Geology, 93: 437-462.

LU, C.; MISRA, K.C.; STONEHOUSE, J.M.; ZWASCHKA, M.R. (1992 Geochemical signature of alteration at the Brewer gold mine, Jefferson, South Carolina. South Carolina Geology, 35: $37 \overline{7} 54$.

MACKENZIE, W.S. \& ADAMS, A.E. (1994) A color Atlas of rocks and minerals in thin section. John Wiley \& Sons, Inc, New York, 192 p.

MACKENZIE, W.S.; DONALDSON, C.H.; GUILFORD, C. (1991) Atlas of igneous rocks and their textures. Hong Kong, Longman Scientific \& Techical, 148 p.

MADER, U.K. \& BERMAN, R.G. (1992) Amphibole thermobarometry: a thermodynamic approach. In: Current Research, Part E. Geol. Surv. Can., 92-1E: 393-340.

MALOOF, T.L.; BAKER, T.; THOMPSON, J.F.H. (2001) The Dublin Gulch intrusion-hosted gold deposit, Tombstone plutonic suite, Yukon Territory, Canada. Miner. Deposita, 36(6): 583-593.

MANIAR, P.D. \& PICCOLI, P.M. (1989) Tectonic discrimination of granitoids. Geol. Soc. Am. Bull., 101(5): 635-643.

MCDOUGALL, I. \& HARRISON, T.M. (1999) Geochronology and Thermochronology by the ${ }^{40} \mathrm{Ar} /{ }^{39} \mathrm{Ar}$ Method. $2^{\text {nd }}$ Edition. Oxford University Press, $269 \mathrm{p}$.

MCMULLIN, D.; BERMAN, R.G.; GREENWOOD, H.J. (1991) Calibration of the SGAM thermobarometer for pelitic rocks using data from phase equilibrium experiments and natural assemblages. Can. Mineral., 29: 889-908.

MELGAREJO, J.C. (1997) Atlas de asociaciones minerales en lâmina delgada. Barcelona, Edicions de La Universitat de Barcelona, 1076 p.

MILLER, C.F.; STODDARD, E.F.; BRADFISH, L.J.; DOLLASE, W.A. (1981) Composition of plutonic muscovite. Can. Mineral., 19: 25-34.

MOTTA, P.S.; JIMENEZ-RUEDA, J.R.; LEITE JR., W.B; PAYOLLA, B.L.; MUZZOLON, R.; BETTENCOURT, J.S. (2000) Caracterização das coberturas de alteração intempérica na região da Mina Bom Futuro, Rondônia: Considerações preliminares. $12^{\text {th }}$ Congresso de Iniciação Científica, UNESP, São José do Rio Preto, Atas, Brazil, p. 149.

MUNOZ, J.L. (1984) F-OH and Cl-OH exchange in micas with applications to hydrothermal ore deposits. In: BAILEY, S.W. (Ed.), Micas, Rev. Mineral., 13: 469-494.

NACHIT, H. (1994) Contribution à la typologie des granitoides, petrogenèse et petrologile structurale du Batholite Panafricain du Cerle de Tafraoute (Boutonniére de Kerdous, AntiAtlas Occidental, Marroc). D'état Thesis, Université Ibhou Zohor, Agadir, Marroco. 
NELSON, C.E. (2000) Volcanic domes and gold mineralization in the Pueblo Viejo District, Dominican Republic. Miner. Deposita, 35: 511525.

NIEDERMANN, S.; BACH, W.; ERZINGER, J. (1997) Noble gas evidence for a lower mantle in MORBs from the southern East Pacific Rise: Decoupling of helium and neon isotope systematics. Geochimica et Cosmochimica Acta, 61: 2697-2715.

NUNES, C.M.D. (2001) Caracterização de um sistema epitermal high-sulfidation paleoproterozóico na Província Aurífera do Tapajós, Pará. Inst. de Geociências, Universidade de São Paulo, São Paulo, Dissertação de mestrado, 174 p.

NUNES, C.M.D.; JULIANI, C.; CORREAA-SILVA, R.H.; BETTENCOURT, J.S.; JACOBI, P.; (2000) Paleoproterozoic quartzalunite epithermal gold mineralization from Tapajós (Brazil). $31^{\text {st }}$ Int. Geol. Congr., IUGS, CPRM, Rio de Janeiro, Brazil, Abstr. [CD-ROM].

NUNES, C.M.D.; JULIANI, C.; CORRÊA-SILVA, R.H.; MONTEIRO, L.V.S.; BETTENCOURT, J.S.; NEUMANN, R.; ALCOVER NETO, A.; RYE, R.O. (2001) Caracterização de um sistema epitermal high-sulfidation vulcânico Paleoproterozóico da Província Aurífera do Tapajós, Pará. In: Simpósio de Geologia da Amazônia, 7, Belém, [CD-ROM].

O'NIONS, R.K. \& BALLENTINE, C.J. (1993) Rare gas studies of basin scale fluid movement. Phil. Trans. Royal Society London, 344: 141-156.

OHMOTO, H. \& LASAGA, A.C. (1982) Kinetics of reactions between aqueous sulfates and sulfides in hydrothermal systems. Geochim. Cosmochim. Acta, 46: 17271746.

OHMOTO, H. \& RYE, R.O. (1979) Isotopes of sulfur and carbon. In: H.L. BARNES (Ed), Geochemistry of hydrothermal ore deposits, second edition. John Wiley and Sons, New York, p. 509567.

OZIMA, M. \& IGARQASHI, G. (2000) The Primordial noble gases in the Earth: a key constraint on Earth evolution models. Earth and Planetary Science Letters, 176: 219-232.

OZIMA, M. \& PODOSEK, F.A. (2002) Noble Gas Geochemistry. $2^{\text {nd }}$ Edition. Cambridge University Press, 286 p.

PASSCHIER, C.W. \&TROUW, R.A.J. (1996) Microtectonics. Berlin, Springer, 289 p.

PEARCE, J.A.; HARRIS, N.B.; TINDLE, A.C. (1984) Trace elements discrimination diagrams for the tectonic interpretation of granitic rocks. J. Petrol., 25: 956-983.

PERELLÓ, J.A. (1994) Geology, porphyry $\mathrm{Cu}-\mathrm{Au}$, and epithermal $\mathrm{Cu}-\mathrm{Au}-\mathrm{Ag}$ mineralization of the Tombulilato district, North Sulawesi, Indonesia. Journal of Geochemical Explorations, 50: 221-256.

PESSOA, M.R.; SANTIAGO, A.F.; ANDRADE, A.F.; NASCIMENTO, J.O.; SANTOS, J. O.; OLIVEIRA, J.R.; LOPES, R.C.; PRAZERES, W.V. (1977) Projeto Jamanxim. Relatório Final, DNPM/CPRM.

PINHEIRO, S. da S. ; FERREIRA, A.L. (1999) Sugestão de redefinição da denominação Formação Palmares, região do Alto tapajós, sudoeste do estado do Pará. Projeto PROMIM/Tapajós. Manaus, CPRM, Relatório Interno, Inédito, 4 p.

POREDA, R.J. \& FARLEY, K.A. (1992) Rare gases in Samoan xenoliths. Earth and Planetary Science Letters, 113: 129-144.

PORTER, T.M. (2001) An overview of the world's porphyry and other hydrothermal copper \& gold deposits and their distribution. http://www.portergeo.com.au/conferences/porph_hyd_cu_au/abstracts/porphpref.pdf. 
POTDEVIN, J.L. \& MARQUER, D. (1987) Méthodes de quantification des transfers de matière par les fluides dans les roches métamorphiques déformées. Geodin. Acta, 1(3): 193-206.

QUADROS, M.L.E.S.; BAHIA, R.B.C.; ALMEIDA, M.E. (1998) Geologia, petrografia e geoquímica preliminar da Suíte Intrusiva Cachoeira Seca, Provincia Mineral do Tapajós, Sudeste do Pará. In: Congresso Brasileiro de Geologia, 40, Belo Horizonte. Anais. Belo Horizonte, SBG/MG, p. 468

QUADROS, M.L.E.S.; BAHIA, R.B.C.; KLEIN, E.L.; VASQUEZ, M.L.; ALMEIDA, M.E.; RICCI, P.S.F.; MONTEIRO, M.A.S. (1999) As intrusões básicas da Província Mineral do Tapajós (PMT) e possibilidades de mineralizações associadas. $6^{\text {th }}$ Simp. Geol. Amazônia, Manaus, Brazil. SBG/NN. Anais, p. 567-569.

RÄMÖ, O.T. \& HAAPALA, I. (1995) One hundred years of Rapakivi Granite. Mineral. Petrol., 52: 129-185.

RAMBRAG, G.E. \& SANTOS, J.O.S. (1974) O Grupo Uatumã. In: Cong. Bras. Geol., 28, Porto Alegre, Anais, 87-94.

RENNE, P.R.; FARLEY, K.A.; BECKER, T.A.; SHARP, W.D. (2001) Terrestrial cosmogenic argon. Earth and Planetary Science Letters, 188: 435-440.

RENNE, P.R.; SWISHER, C.C.; DEINO, A.L.; KARNER, D.B.; OWENS, T.L.; DEPAOLO, D.J. (1998) Intercalibration of standards, absolute ages and uncertainties in ${ }^{40} \mathrm{Ar} /{ }^{39} \mathrm{Ar}$ dating: Chem. Geol., 145: $117 \overline{7} 152$.

RENNE, P.R.; SWISHER, C.C.; DEINO, A.L.; KARNER, D.B.; OWENS, T.L.; DE PAOLO, D.J. (1998b) Intercalibration of standards, absolute ages and uncertainties in ${ }^{40} \mathrm{Ar} /{ }^{39} \mathrm{Ar}$ dating: Chemical Geology, 145: 117-152.

REIS, N.J.; FARIA, M.S.G. de; FRAGA, L.M.B.; HADDAD, R.C. (1999) Vulcanismo calcioalcalino Paleoproterozóico do setor oriental do estado de Roraima - escudo das Guianas. In: SIMPÓSIO SOBRE VULCANISMO E AMBIENTES ASSOCIADOS, 1., Gramado, 1999. Boletim de Resumos. Gramado, SBG-RS. p.78

RICCI, P.S.F.; SANTOS, A.; KLEIN, E.L.; JORGE-JOÃO, X.S.; MARTINS, R.C. (1999) Suíte Intrusiva Creporizão - Província Tapajós: proposta e critérios de definição. $6^{\text {th }}$ Simp. Geol. mazônia, Manaus, Brazil. SBG/N, Anais,pp. 519-522.

RODDICK, J.C. (1983) High precision intercalibration of ${ }^{40} \mathrm{Ar}-{ }^{39} \mathrm{Ar}$ standards. Geochimica et Cosmochimica Acta, 47: 887-898.

ROEDDER, E. (1984) Fluid inclusions. Reviews in Mineralogy, 12, Mineralogical Society of America.

ROWINS, S.M. (2000) Reduced porphyry copper-gold deposits: a new variation on an old theme. Geology, 28: 491-494.

RYE, R.O. (1993) The evolution of magmatic fluids in epithermal environment: the stable isotope perspective (SEG Distinguished Lecture). Econ. Geol., 88: 733-753.

RYE, R.O.; BETHKE, P.M.; WASSERMAN, M.D. (1992) The stable isotope geochemistry of acid sulfate alteration. Econ. Geol., 87: 225-262.

RYE, R.O. (in press) Review of the stable isotope geochemistry of sulfate minerals in selected volcanic enviornments and related hydrothermal systems. Chem. Geol.

RYE, R.O.; STOFFREGEN, R.E.; BETHKE, P.M. (1990) Stable isotope systematics and magmatic hydrothermal processes in the Summitville, CO gold deposit. U. S. Geol. Surv. Open-File Report, 90-626, 31 p. 
SAMSON, S.D. \& ALEXANDER, E.C. (1987) Calibration of interlaboratory ${ }^{40} \mathrm{Ar} /{ }^{39} \mathrm{Ar}$ dating standard, MMhb-1. Isotope Geoscience, 66: 27-34.

SANTOS, D. B.; FERNANDES, P.E.C.A.; DREHER, A.M.; CUNHA, F.M.B.; BASEI, M.A.S.; TEIXEIRA, W. (1975) Levantamento de recursos naturais. Geologia. Projeto Radam, Folha SB. 21 - Tapajós, V.7, 418 p.

SANTOS, J.O.S. (1984) A parte setentrional do Cráton Amazônico (Escudo das Guianas) e a Bacia Amazônica. In: Schobbenhaus, C.; Campos, D.A.; Derze, G.R.; Asmus, H.E. (Coord.) Geologia do Brasil: texto explicativo do mapa Geológico do Brasil e da área adjascente incluindo depósitos minerais, Escala 1:2.500.00. Brasília, DNPM/MME. p. 5891.

SANTOS, J.O.S. (1999) New understanding of the Amazon Craton Gold Provinces. In: New developments in Economic geology. Centre for teaching and research in strategic mineral deposits.The University of Western Australia. Perth, unpublished report, $10 \mathrm{p}$.

SANTOS, J.O.S. \& LOGUERCIO, S.O.C. (1984). A parte meridional do Cráton Amazônico (Escudo Brasil Central) e as bacias do Alto Tapajós e Parecis-Alto Xingu. In: C.C. Schobbenhaus, D. A.; Derze, G. R.; Asmus, H. E. (Eds.), Geologia do Brasil : Texto Explicativo do Mapa Geológico do Brasil e da Área Adjascente Incluindo Depósitos Minerais, Escala 1:2.500.000. DNPM/MME, Brasília, p. 93-127.

SANTOS, J.O.S.; BORGES, O.C.; SOUZA, M.M.; PESSOA, M.R. (1974) Projeto Norte da Amazônia, Domínio Baixo Rio Negro. Relatório Final, Manaus, CPRM 4V., il.

SANTOS, J.O.S.; GROVES, D.I.; HARTMANN, L.A.; MOURA, M.A.; MCNAUGHTON, N.J. (2001) Gold deposits of the Tapajós and Alta Floresta Domains, Tapajós-Parima orogenic belt, Amazon craton, Brazil. Miner. Deposita, 36: 278-299.

SANTOS, J.O.S.; HARTMANN, L.A.; GAUDETTE, H.E. (1997) Reconnaissance U/Pb in zircon; $\mathrm{Pb} / \mathrm{Pb}$ in sulfides and review of $\mathrm{Rb} / \mathrm{Sr}$ geochronology in the Tapajós Gold Province; Pará/Amazonas States, Brazil. In: South American Symposium on isotope geology. Campos de Jordão, Extended abstracts, 280-282.

SANTOS, J.O.S.; HARTMANN, L.A.; GAUDETTE, H.E.; GROVES, D.I.; MCNAUGHTON, N.J.; FLETCHER, I.R. (2000) A new understanding of the Provinces of the Amazon Craton based on integration of field mapping and $\mathrm{U}-\mathrm{Pb}$ and $\mathrm{Sm}-\mathrm{Nd}$ geochronology. Gondwana Res., 3(4): 453-488.

SANTOS, J.O.S.; HARTMANN, L.A.; McNAUGHTON, N.; FLETCHER, I.R. (1999) Uma inesperada idade cambriana para o enxame gigante de diques máficos na Província Aurífera do Tapajós, obtida pela geocronologia U-Pb em baddeleyta e zircão. In: Simpósio de Geologia da Amazônia, 6, Manaus, Anais, 482-485.

SATO, K.; TASSINARI, C.C.G. (1997) Principais eventos de acresção continental no Cráton Amazônico baseados em idade-modelo $\mathrm{Sm}-\mathrm{Nd}$, calculada em evolução de estágio único e estágio duplo. In: M.L.A. Costa, R. S. (ed), Contribuições à Geologia da Amazônia. Belém, FINEP/SBG-NO, 91-142.

SCHMIDT, M.W. (1992) Amphibole compositions in tonalite as a function of pressure: an experimental calibration of the Al-in-hornblende barometer. Contrib. Mineral. Petrol., 110: 304-310.

SCHUMACHER, J.C. (1997) The estimation of ferric iron in electron microprobe analysis of amphibols. Eur. J. Mineral., 9: 643-651. 
SELBY, D. \& NESBITT, B.E. (2000) Chemical composition of biotite from the Casino porphyry $\mathrm{Cu}-\mathrm{Au}-\mathrm{Mo}$ mineralization, Yukon, Canada: evaluation of magmatic and hydrothermal fluid chemistry. Chem. Geol., 171: 77-93.

SILLITOE, R.H. (1973) The tops and bottoms of porphyry copper deposits. Econ. Geol., 68: 799015.

SILLITOE, R.H. (1991) Intrusion-related deposits. In: FOSTER, R.P. (Ed), Gold metallogeny and exploration. Chapman \& Hall, London, p.165-209.

SILLITOE, R.H. (1993) Gold-rich porphyry copper deposits: geological model and exploration implications. Geol. Ass. Can. Spec. Pap., 40: 465-478.

SILVA, A.R.B. (1982) Considerações sobre as mineralizações auríferas da Região do Tapajós. In: Simpósio de Geologia da Amazônia, 1. Anais..., SBG/NN, Belém, p. 100-115.

SILVA, G.H.; LEAL, J.W.L.; SALUM, O.A.L.; DALL'AGNOL, R.; BASEI, M.A.S. (1974) Esboço geológico de parte da folha SC.21 Juruena. In: Cong. Bras. Geol., 28, Porto Alegre, Anais, 309-320.

SILVA, G.G.; LIMA, M.I.L.; ANDRADE, A. F.; ISSLER, R.S.; GUIMARÃES, G. (1974) Geologia - Folha SB.22 Araguaia e parte da SC.22 Tocantins. Projeto Radam, Levantamentos de recursos minerais 4, Rio de Janeiro, 1-60.

SLANSKY, E. (1973) The thermal investigation of alunite and natroalunite. Neues Jahrbuch fuer.

SNEE, L.W. (2002) Argon thermochronology applied to mineral deposits - a review of analytical methods, formulations, and selected applications, U.S. Geological Survey Bulletin, in press.

SO, C.-S., ZHANG, D.-Q., YUN, S.-T., Li, D.-X. (1998) Alteration-mineralization zoning and fluid inclusions of the high sulfidation epithermal CuAu mineralization at Zijinshan, Fujian Province, China. Econ. Geol., 93(7): 961980.

STEIGER, R.H. \& JÄGER, E. (1977) Subcommission on geochronology: convention on the use of decay constants in geo- and cosmochronology. Earth and Planetary Science Letters, 36: $359-362$.

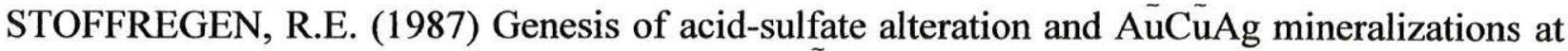
Summitville, Colorado. Econ. Geol., 82: 15751591.

STOFFREGEN, R.E. \& ALPERS, C.N. (1987) Woodhouseite and svanbergite in hydrothermal ore deposits: Products of apatite destruction during advanced argillic alteration. Can. Mineral., 25: 201212.

STOFFREGEN, R.E.; ALPERS, C.N.; JAMBOR, J.L. (2000) Alunitejarosite crystallography, thermodynamics, and geochronology. In: C.N. ALPERS, J.L. JAMBOR, D.K. Nordstrom (Eds), Sufate minerals Crystallography, geochemistry, and environmental significance. Rev. Mineral. Geochem., 40: $45 \tilde{4} 479$.

STOFFREGEN, R.E. \& CYGAN, G.L. (1990) An experimental study of NaK exchange between alunite and aqueous sulfate solutions. Am. Mineral., 75: $20 \tilde{9} 220$.

STOFFREGEN, R.E.; RYE, R.O.; WASSERMAN, M.D. (1994) Experimental studies of alunite: $\mathrm{I}^{18} \tilde{\mathrm{O}}^{1 \square} \mathrm{O}$ and $\tilde{\mathrm{DH}}$ fractionation factors between alunite and water at $250450{ }^{\circ} \mathrm{C}$ : Geochim. Cosmochim. Acta, 58: $90 \tilde{3} 916$.

TASSINARI, C.C.G. (1996) O mapa geocronológico do Cráton Amazônico no Brasil: revisão dos dados isotópicos. Inst. de Geociências, Universidade de São Paulo, São Paulo, Tese de Livre-Docência, 139 p. 
TASSINARI, C.C.G. \& MACAMBIRA, M.J.B. (1999) Geochronological Provinces of the Amazonian Craton. Episodes, 22(3): $17 \tilde{4} 182$.

THOMPSON, J.F.H.; LESSMAN, J.; THOMPSON, A.J.B. (1986) The Temora goldsilver deposit: a newly recognized style of high sulfur mineralizations in the Lower Paleozoic of Australia. Econ. Geol., 81: 732738.

TRÖGER, W.E. (1979) Optical determination of rock-forming minerals - Part 1: determinations Tables. Stuttgart, E. Schweizerbart'sche Veragsbuchhandlung. 188 p.

TRULL, T.W. \& KURZ, M.D. (1999) Isotopic fractionation accompanying helium diffusion in basaltic glass. Jour. Molecular Structure, 485-486: 555-567.

TRULL, T.W.; KURZ, M.D.; JENKINS, W.J. (1991) Diffusion of cosmogenic ${ }^{3}$ He in olivine and quartz: implications for surface exposure dating. Earth and Planetary Science Letters, 103: 241-256.

VASCONCELOS, P.M. (1999) K-Ar and ${ }^{40} \mathrm{Ar} /{ }^{39} \mathrm{Ar}$ geochronology of weathering processes. Annual Reviews Earth and Planetary Sciences, 27: 183-229.

VASCONCELOS, P.M.; BRIMHALL, G.H.; BECKER, T.A.; RENNE, P.R. (1994) ${ }^{40} \mathrm{Ar} /{ }^{39} \mathrm{Ar}$ analysis of supergene jarosite and alunite: implications to the paleoweathering history of the western USA and West Africa. Geochimica et Cosmochimica Acta, 58: 401-420.

VASQUEZ, M.L. \& KLEIN, E.L. (2000) Geologia e recursos minerais da Folha Rio Novo (SB.21-ZC). Estado do Pará, Escala 1:250.000. PROMIM Tapajós, CPRM, Brasília, Brazil [CD-ROM].

VASQUEZ, M.L.; KLEIN, E.L.; QUADROS, M.L.E.S.; BAHIA, R.B.C.; SANTOS, A. dos; RICCI, P.S.F.; SACHETT, C.R.; SILVA, C.M.G.; MACAMBIRA, M.J.B. (1999) Magmatismo Uatumã na Provincia Tapajós -novos dados geocronológicos. In: Simpósio de Geologia da Amazônia, 6., Manaus, 1999. Anais. Manaus, SBG/NN, p. 471-474

VASQUEZ, M.L.; SANTOS, A. dos; KLEIN, E.L.; FRAGA, L.M.; MAIA, R.G.N.; MARTINS, R.C. (1996) Reconhecimento Geológico na Região do Médio Tapajós. In: Simpósio de Geologia da Amazônia, 5., Belém, 1996. Anais. Belém, SBG. p.117-118.

WASSERMAN, M.D.; RYE, R.O.; BETHKE, P.M.; ARRIBAS JR., A. (1992) Methods for separation and total stable isotope analysis of alunite. U.S. Geol. Surv. Open-file Report 92-9, 20 pp.

WHALEN, J.B.; CURRIE, K.L.; CHAPPELL, B.W. (1987) A-type granites: geochemical characteristics, discrimination and petrogenesis. Contrib. Miner. Petrol., 95: 407-419.

WONES, D.R. \& EUGSTER, H.P. (1965) Stability of biotite: experiment, theory and application. Am. Mineral., 50(9): 1228-1272.

YATSEVICH, I. \& HONDA, M. (1997) Production of nucleogenic neon in the earth from natural radioactive decay. Jour. Geophysical Research, Solid Earth, 102(B5): 10291-10298.

ZANG, W. \& FYFE, W.S. (1995) Chloritization of the hydrothermally altered bedrock at the Igarapé Bahia gold deposits, Carajás, Brazil. Miner. Deposita, 30: 30-38.

ZHU, C. \& SVERJENSKI, D.A. (1992) F-Cl-OH partitioning between biotite and apatite. Geochim. Cosmochim. Acta, 56: 3435-3467. 